\title{
Carl-Gustav Lindén
}
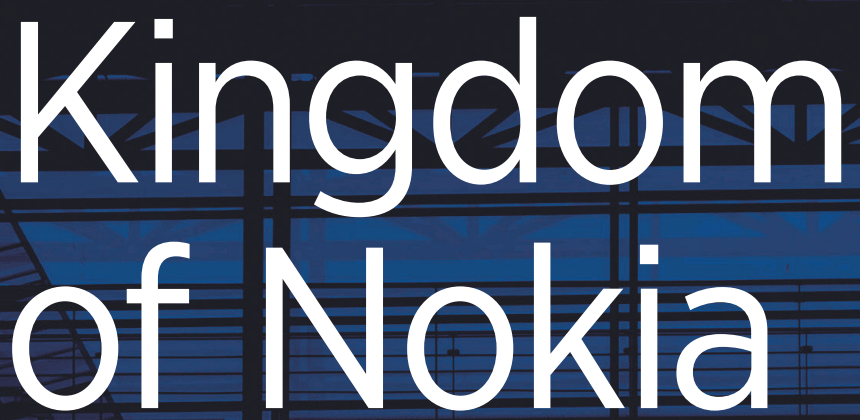

How a Nation

Served the Needs of One Company

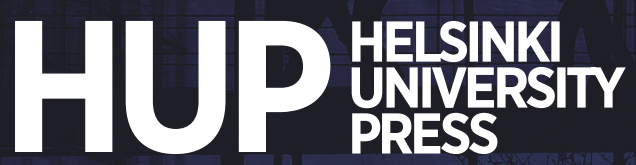


Carl-Gustav Lindén

\section{Kingdom of Nokia}

\section{How a Nation Served the Needs of One Company}




\author{
Published by \\ Helsinki University Press \\ www.hup.fi \\ Text (c) Carl-Gustav Lindén 2021 \\ Translation (C) Patrick Humphreys 2021 \\ First published in 2021 \\ Cover design by Ville Karppanen \\ Cover photo by Martti Kainulainen, Lehtikuva
}

Print and digital versions typeset by Siliconchips Services Ltd.

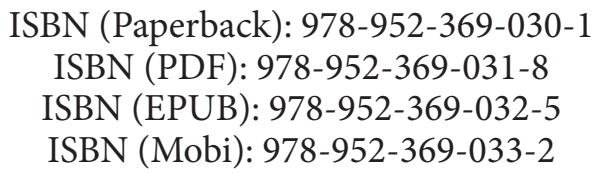

DOI: https://doi.org/10.33134/HUP-8

This work is licensed under the Creative Commons Attribution NonCommercial 4.0 International License (unless stated otherwise within the content of the work). To view a copy of this license, visit https:// creativecommons.org/licenses/by-nc/4.0/ or send a letter to Creative Commons, 444 Castro Street, Suite 900, Mountain View, California, 94041, USA. This license allows sharing and copying any part of the work, providing author attribution is clearly stated. Under this license, the user of the material must indicate if they have modified the material and retain an indication of previous modifications. This license prohibits commercial use of the material.

The full text of this book has been peer reviewed to ensure high academic standards. For full review policies, see http://www.hup.fi/

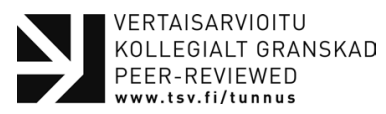

Suggested citation:

Lindén, C.-G. (2021). Kingdom of Nokia: How a nation served the needs of one company. Helsinki University Press.

DOI: https://doi.org/10.33134/HUP-8.

To read the free, open access version of this book online, visit https://doi.org/10.33134 /HUP-8 or scan this QR code with your mobile device:

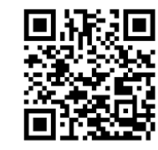




\section{Contents}

Acknowledgements $\quad \mathrm{V}$

Preface ix

Chapter 1: Introduction 1

Chapter 2: A Nation Ensnared 29

Chapter 3: To the Open Market 55

Chapter 4: Troubled Media Relations 67

Chapter 5: Who Dared Defy Ollila? 79

Chapter 6: Politics and Lobbying 95

Chapter 7: Raining Riches 103

Chapter 8: Nokialand Is Born 111

Chapter 9: Subcontractors in Crisis 121

Chapter 10: The Fall of Elcoteq 135

Chapter 11: Factory Exodus to China 143

Chapter 12: Shattered Dreams: India 153

Chapter 13: The Tale of Two Cities 161

Chapter 14: The Decisive Year 167

Chapter 15: Symbian Crashes 177

Chapter 16: Debacle in the United States 189

Chapter 17: Surrender to Microsoft 199

Chapter 18: Another Future 209

Notes 221

Appendix A: List of Interviewees 223

References 229

Index 251 



\section{Acknowledgements}

This book is the result of a long personal process starting back in the 1980s, when I was a young business reporter trying to understand global business through the prism of Nokia. The professional interest changed from journalistic to reflective academic thinking when I worked on my PhD, National Champions in Combat: Nokia, Ericsson and the Sensemaking of Business News (2012). This was followed up with a book in Swedish published in 2015, and a Finnish edition in 2016, which is also the foundation for this edition.

There are so many people I would like to thank, above all those who shared their knowledge when interviewed for this book. I hope you will find it worth the trouble. Others helped me by reading and commenting on different versions of the manuscript. Over the years, I have also enjoyed discussing this topic with many people more knowledgeable than me and the book has benefited immensely from their input. In many senses, this book is the result of a collective process and would certainly have been less insightful and interesting without the input of close to 200 people. 
The downside of writing non-fiction books is that facts can be checked and any errors are certainly my sole responsibility.

$\mathrm{PhD}$ student Andreas Eklund spent many hours transcribing interviews, while Professor Susanna Fellman introduced me to the dynamics of Nordic capitalism and Patrik Westerback provided valuable help with transforming historical prices and values. The editor for the first version of this book, Jonna Brander at Schildts \& Söderströms, firmly helped me turn my random reflections into a readable structure that smoothed the way for the subsequent editions. Pekka Nykänen, a journalist with a deep knowledge of Nokia, expertly translated the manuscript into Finnish. My editor at Gaudeamus, Teemu Ojanne, gave the text a rigorous treatment and proposed excellent changes. And, for the English edition, journalist Pat Humphreys translated the text with a keen sense of what would be understandable to a non-Finnish readership. It was with great joy I found out that Anna-Mari Vesterinen at Helsinki University Press would be my editor. We worked closely together in our previous jobs where she made a strong impression as a professional who seeks excellence in academic publishing. I am immensely grateful to Leena Kaakinen, Publishing Director at Helsinki University Press, Publishing Coordinator Heta Björklund and their colleagues for accepting and processing the manuscript for publication. Three anonymous reviewers gave valuable comments that helped me steer the work towards a stakeholder perspective. Unfortunately, I have still been unable to follow the advice and turn the manuscript into a series of podcasts. Financially, my work was made possible by generous grants from the Association of Finnish Non-fiction Writers and the Finnish Association of Science Editors and Journalists, as well as Stiftelsen Finlandssvensk Bokkultur.

I have worked on this book in many European countries, and also in the United States and India. However, most of the text emerged during a long stay at Villa Lante al Gianicolo, the Finnish Institute in Rome. My sincere thanks go to intendant Simo Örmä for accepting me at the residence, which has become my favourite space for writing books. Standing one evening on the beautiful 
terrace and letting my gaze travel across Rome, I thought of the confluence of the city's history with the rise and fall of the Nokian Empire. Rome used the same method for gaining and maintaining power: divide and conquer. Both splintered their opponents into small groups that could be picked off, one by one. At the same time, I came up with a witty question for a general knowledge quiz: What is the difference between the Nokian and Roman empires? Answer: 480 years. Nokia divided and conquered for less than 20 years, Rome for 500. I will leave this metaphor to the study of others, but, as a hint to those interested, the bookshelves of Villa Lante groan with profound analyses of the fall of the Roman Empire. 



\section{Preface}

This book examines an iconic tech company that transformed the world by providing a new communication tool, the mobile phone, on an affordable and massive scale. However, the company resides in a small country in Northern Europe, Finland. This monograph presents the fascinating story of how a huge global company and a Nordic country emerged in co-evolution and formed what became a brand nation that we here call 'Kingdom of Nokia'. The title of the book comes from the idea that Nokia for around 15 years managed to capture the attention of the Finnish elite, from politicians and civil servants to journalists willing to serve in the best interest of the global company that put Finland on the world map.

We trace the development of Nokia's success in mobile phones back to the development of radio technology in the 1930s and Finnish military spending on radio phones in the 1960s. We can track path dependence back to the coordinated Nordic development of the Nordic Mobile Telephony (NMT) standard, the first fully automatic cellular phone system which later, through concerted lobbying efforts at the European level, turned into the European standard GSM (1G). The standard is still used today and $5 \mathrm{G}$ is 
the latest addition. The Finnish government also helped with state support for R\&D in relevant technologies and processes, such as advanced manufacturing of electronic devices.

One important theme is Nokia's struggle with new technology, moving from hardware to software and internet to web. The book deals with the failed attempt to introduce a new operating system for mobile phones, getting away from the impossibly dated Symbian to modern systems. The struggle has been attributed to the incapability of Finnish software engineers to understand modern software, but the book points at strategic and managerial shortcomings.

It also examines the factors that initially made the success possible-refusal to give up and belief in its own capacity successfully to deal with problems-but later were the very same forces that brought the company close to destruction. Success breeds arrogance and, for too long, Nokia's management refused to accept that the rules of the game had changed.

The individual who made the company so strong in the national debate was the CEO and Chairman Jorma Ollila, who had close connections to the politically dominant Centre Party and in particular the former Prime Minister Esko Aho. Both are still important influencers in national policy. Thus, the book explores how economic elites are being formed and their influence on institution building.

Kingdom of Nokia covers a wide range of issues. One dominant theme is how Nokia became a global player in mobile communications, was listed on the New York Stock Exchange and, as a consequence, helped establish Anglo-Saxon capitalism in Finland. Through its unexpected success in the 1990s, the company managed to capture the attention of every segment of the Finnish elite, from politicians of all parties to government officials, state funding agencies, standardisation agencies, labour unions and journalists. With concrete detailed examples, the book illustrates how Nokia paid millions in campaign money to politicians in a country that is considered one of the least corrupt in the world. Nokia also played an important role in major national decisions in Finland, such as joining the European Union and adopting the euro. 


\section{CHAPTER ।}

\section{Introduction}

I have dealt with Nokia throughout my career as a business journalist from 1985 to 2010 , and have been studying the company as a researcher since then. I regard myself as rather well informed about the company; however, I was never part of the company's inner circle. Still, at a party in 2010, Lauri Kivinen, a Nokia employee from 1988 to 2010 and former Head of Communications, introduced me as a 'co-worker'. I responded cautiously that we were never actually colleagues, because I was a journalist and he was part of Nokia's public relations team. 'Yes, yes', he shot back, 'but we worked together'. Our complicity was self-evident. Privileged journalists received special treatment from Nokia's communications department, including invitations to capital market events and glamorous mobile phone exhibitions in Cannes (1987-2006) and later Barcelona. The Swedish business correspondent, Bengt Carlsson, who was a member of this elite, said in his interview that Nokia's managers, journalists, analysts and other members were like a touring theatre company where everyone knew everyone. I needed to reassess my status as an independent journalist and a watchdog. As an economic correspondent, I was not particularly good at seeing events at Nokia from the right perspective. Only after studying Nokia from a researcher's point of view, since 2011, have I been able to examine the company's various turning points more objectively. 
I began writing the first version of this book in autumn 2013, when Nokia sold its mobile phone division to Microsoft after a strategic failure. It was an opportune moment to use the knowledge accumulated over a lengthy period of studying the relationship between Nokia and Finland for my PhD thesis (Lindén 2012). The outflow of emotions in Finland after the sale of Nokia phones, accompanied by accusations of treason, showed how bewildering this relationship had been. Finland seemed to be in national mourning. However, Nokia was and is far from a smoking ruin. Even without mobile phones, it is a successful worldwide corporation. This book can therefore be regarded as an interim report, wrapping up the historically rare and fleeting period from around 1980 to 2020 when a Finnish company could bask in global adulation as the source of advanced consumer goods known to all. In this same period, Nokia came to dominate key sectors of Finnish society, as politicians and others sought desperately to claim and cling on to its unexpected success. We do not yet know all the details. Most political revelations come long after the event.

\section{Four Global Stories}

The first global story concerns Finland's entry to the world of global capitalism and the benefits of accommodating a huge international company. It also looks at the other side of the coin, a Nordic welfare state dependent on one field of technology and the special interests of one dominant actor with an Anglo-Saxon business mindset. In that context, ideas and argumentation associated with the welfare state have given way to a pro-market business discourse associated with neoliberal ideology (Poutanen 2019).

According to the Etla economic research institute, as recently as 2008 Nokia produced by far the most value-added in the Finnish economy: 4.8 billion euros. Value-added is the total of profits, labour costs, depreciation costs and rent. Large corporations are more important to Finland than to neighbouring countries; Finland's 20 largest export companies produce half of its exports, while in 
Sweden and Denmark the proportion is a third. Nokia's valueadded was twice as great as that of the financial group Nordea, which was second largest. Almost a quarter of Finnish corporation tax was paid by Nokia. Just five years later, in 2013, Nokia's name briefly disappeared from the top 10 list of the most valuable Finnish companies.

Major corporations with a corresponding position have been Royal Dutch Shell in the Netherlands, Samsung in Korea and Gazprom in Russia, but they have not had the same influence on the real economy of their home countries. Everyone who lived the Nokia dream awoke to the harsh reality of its decline, as tens of thousands of jobs disappeared at Nokia and its subcontractors. Politicians have still to come to terms with the acute problem of restructuring, now that the state budget has lost the massive support of a worldwide corporation.

What was it like to live in the Kingdom of Nokia? This was a company with huge institutional impact on policymaking, to the extent that it was even able to write its own laws. Political campaign funding, strong lobbying and outright coercion were some of the impact tools utilised. When Nokia decided to sell its mobile phone business in 2013, it left the whole nation in shock. Deriving insights from ignorance studies and agnotology (Croissant 2014; Gross \& McGoey 2015; Roy \& Zeckhauser 2015; Proctor \& Schiebinger 2008), this part of the book answers three important questions: What did members of Finland's elite know about Nokia? What did they not know? Most importantly, what did they not want to know and why?

The second global story relates to China and the country's long-standing relationship with Nokia, going back to the mid1980s. Thanks to the cooperation and exchange of technology and expertise with Nokia and other global tech companies, often unintended and bordering on industry espionage, China has, in just two decades, become a world leader in mobile communications. The evidence for this statement is obvious when looking at the future of $5 \mathrm{G}$ technology and China's massive investments and technical superiority in this field. 
The third global story covers the rise of mobile communications in India, giving hundreds of millions of Indians means to connect with families, friends and business associates. The history of Nokia in India is also the story of a giant nation getting connected to the rest of the world. Less known is the story of how Nokia identified the potential of an emerging market and managed to lobby the Indian government into following its advice for deregulation and lower import taxes on mobile phones. Unfortunately, when the market for smartphones exploded, Nokia was no longer present as the mobile business had been sold to Microsoft. What is left of major investments in manufacturing capacity are gigantic, empty factories outside Chennai in Tamil Nadu.

The fourth and last, but not the least important, global story, is the rise of Silicon Valley in mobile communications, how Nokia in just a few years went from an unbeatable market share of mobile phones with absolute world domination to oblivion. Nokia management saw the advent of the iPhone (Apple) and Android (Google) much like air traffic controllers at an airport see airplanes land and depart, but were prisoners of their own success and incapable of addressing the imminent challenges. This global story also deals with the overall feature of Silicon Valley giants conquering the world.

Why did Nokia go down? Years of success had bred a corporate culture characterised by hubris, obsessed with cost control, savaged by fights between middle managers, marked by a fear of being the harbinger of bad news and, perhaps most importantly, a CEO and chairperson who mostly resembled a dictator everybody lived in fear of, including outside the company. One important explanation is Nokia's struggle with new technology, moving from hardware to software and internet to web. Nokia had every opportunity to meet the challenges from the iPhone and Android, but failed to make the right decisions. We look closely at the failed and painful attempt to introduce a new operating system for mobile phones, getting away from the impossibly dated Symbian system to modern ones. 


\section{Methodology}

This book is very much an oral history of Nokia and Finland, as it is based on semi-structured or open-ended interviews conducted in the period from 2015 to 2019, predominantly in Finland, but also in Sweden, Estonia, the United States, the United Kingdom, Singapore and India. Some people have been interviewed several times to allow for checking missing information or facts. Most of these people have been or are working for Nokia, but the list also includes subcontractors, civil servants, politicians, journalists, industry experts and academics. All interviews have been recorded, transcribed and categorised according to the topics covered. The book also makes extensive use of news and industry reports on Nokia, as well as official documents.

Some people refused the interviews altogether. Nokia's past involves many successes, but recent years have contained failures that are difficult to come to terms with. Perhaps some of the people I approached wanted to keep the success story alive. Others may have had legal reasons for refusing to discuss any events at Nokia. This is why I believe that the study of this subject will continue long into the future. I know of researchers who have obtained interviews only by promising that the person would not be quoted until after their death.

In my efforts to explain the different stages of Nokia's development trajectory, I have been inspired by institutional theory; that society develops according to laws, norms and rules, written and unwritten, and how they are applied, as well as to behavioural models, habits, half-truths, myths and prevailing logic. The US economic historian and Nobel laureate Douglass North (2005) describes institutions as 'the rules of the game'. A demotic definition of an institution would be: the way we do things over here (March \& Olsen 1989; Scott 2001). Nokia is a modern global tech company with deep historical roots in Finnish soil, going back to the second half of the 19th century, and has been balancing its heritage with the image of tech future. However, it has been unable to escape its Finnishness, or perhaps has not tried hard 
enough. This was especially obvious during the period from 2004 to 2008, when Nokia's mobile phones ruled the rest of the world, except for the United States. Stubbornly, Nokia thought that what was good enough for Europeans should also be sufficient for Americans, thus missing what was going on in Silicon Valley and the emergence of the iPhone and Android.

I see institutions principally as behavioural models that are subconscious or tangible to those involved, but are often invisible to outsiders. In this case, the question is how the political and economic elite in Finland acted in relation to Nokia. What patterns directed the behaviour and exercise of power by those in positions of power? My perspective is therefore elitist (Corcoran 2009; Robinson 2010; Ruostetsaari 2007). I offer few to no insights on how the majority of the population experienced Nokia.

Conceptually, the book is framed by institutional theory, focusing on elite discourses and actions (Burns \& Nielsen 2006; Campbell 1998; DiMaggio 1988; Djelic \& Quack 2003; Granovetter 1992; March \& Olsen 1989; North 1990; Scott \& Meyer 1994). Looking at institution building and stakeholder relations, we explore how Finland almost by coincidence acquired a peculiar form of economic nationalism (Helleiner \& Pickel 2005) and became a brand nation (Aronczyk 2013; Moilanen \& Rainisto 2009; Van Ham 2001), though not in the sense of commodified national identity (Comaroff \& Comaroff 2009), but banal nationalism (Billig 1995). Finland's active attempt at nation branding failed, but instead the country's nation brand developed more or less without any campaigns or coordination. Institutional theory is useful for interpreting the motivations of decision-makers. As Stefan Tengblad has pointed out, it is based on three interrelated phenomena: rules, players and actions (Tengblad 2006). In his view, the main focus should be on what the players-'the Romans'-do. Although their acts are directed by visible or invisible rules, decision-makers do not obey them blindly, but have an identity built on their actions. Actions also give rise to new rules, and this book contains a few examples of such changes, for instance in the law. 
Institutional theory is good at explaining why things tend to stay as they are, and much less adopted for understanding disruptive technological change, one key theme of this book. Still, traditional explanations of technological change neglect the social embeddedness of the process through which new innovations become widely accepted (Granovetter 1985; Hargadon \& Douglas 2001; Munir \& Phillips 2005).

This book is also inspired by other forms of social construction, such as stakeholder relationship theory. Through this lens, the book examines actors in Nokia's network, their interests and reasons for actions and change over time. For instance, it is important to recognise 'the wider configuration of businesses, industries, communications platforms, services and networks that have made the cell phone possible' (Goggin 2006: 8). Theory around the concept of stakeholders provides a rich context for discussing who these people or organisations are and what are at 'stake' (Miles 2017; Mitchell, Agle \& Wood 1997). Stakeholders are individuals, groups of people and organisations in the political and economic system we know as Finland. This network includes managers, the board of directors, employees, subcontractors, competitors, researchers, state agencies, regulators, unions, civil servants, journalists, politicians and, not least, the company's shareholders. They all have crucial relevance to Nokia's development and success or failure. Perhaps the most important stakeholders are top corporate managers themselves and, in the case of Nokia, Stakeholder Number One was Jorma Ollila.

Nevertheless, the book argues that the network of stakeholders could also include ordinary Finns who have bought in to the idea of a Finnish national champion (Lindén 2012), a global company whose interests are crucial and need to be served by 'the nation'. Even retired people are dependent on the return on investments by financial companies responsible for pensions.

The institutional perspective plays a background role in influencing the conclusions of this book. Although we know that economic development is dependent on investment and technology, progress also requires appropriate political, legal, 
economic and other institutions. Admittedly, it is difficult to find agreement on what these institutions might be, but the issue concerns complex and interrelated social structures that provide stability and predictability.

\section{Literature}

Nokia has been, and continues to be, a popular subject for research and authorship. In 2000, two Finnish journalists, Staffan Bruun and Mosse Wallén, published Boken om Nokia (Bruun \& Wallén 2000), a narrative that told perceptively how the giant corporation came back from the verge of bankruptcy and renewed itself to become the world's largest manufacturer of mobile phones. Bruun and Wallén point out that Nokia created an entirely new industry sector. Written at the turn of the millennium, the book is tinged with the zeitgeist, optimism and anticipation of the next thousand years. During that time, the internet was changing the world and everyone was expected to benefit from this new technology. In February 2000, Nokia did indeed become the world's fifth most valuable company. In June, Nokia's share price rose to an all-time high of $€ 65$.

There was a steady flow of heroic tales, written with the assistance of Jorma Ollila and other Nokia executives. An early example is Nokia Saga (1995), commissioned by the Nokia management from the copywriter Marco Mäkinen. It was intended to reinforce Nokia's corporate culture and identity, but, together with his closest subordinates, Ollila reshaped the text into a celebration of company management. In 2001, Dan Steinbock published The Nokia Revolution: The Story of an Extraordinary Company that Transformed an Industry (2001), which opens up the history of Nokia. The following year saw Trevor Merriden's admiration of the 'coolest telecom company in the world': Business the Nokia Way: Secrets of the World's Fastest Moving Company (2001). Harvard researchers Örjan Sölvell and Michael E. Porter joined in the chorus of adulation with Finland and Nokia: Creating the World's Most Competitive Economy (Sölvell \& Porter 2002), which sets the 
institutional context for Nokia's success: policy changes made in the 1990s. Then in 2010 came Steinbock's second eulogy Winning Across Global Markets: How Nokia Creates Strategic Advantage in a Fast Changing World (Steinbock 2010). Its blurb promised 'a roadmap for developing, capturing, and sustaining strategic global advantage. It had the misfortune to appear just as Nokia lost its footing.

Finnish historian Martti Häikiö wrote an entire trilogy about Nokia (Häikiö 2001a; Häikiö 2001b; Häikiö 2001c), with a condensed version of the most important events in English (Häikiö \& Virtanen 2002). These have been an important factual source while studying the company prior to 2000 as Häikiö has enjoyed the luxury of unrestricted access to Nokia's archives. However, the book series was commissioned by Nokia's board of directors and work controlled by a committee of board members and employees.

History is often used for branding purposes where managing the past becomes an important function of corporate communications. The need for control arises especially when problematic episodes occur and events or issues do not unfold as planned. Organisations may be stigmatised by their life histories and unable to explore or identify alternatives as choices 'because their life trajectory propels them in a particular direction' (Carroll 2002: 559). But companies can also use history-telling to reverse that process and use images of the future to help reshape images of the past, 'to recast the past in more appreciative terms, to reframe the past to highlight images or interpretations that can be just as real, authoritative, and inspirational as the ones we inadvertently use to guide our lives' (Carroll 2002: 559). Organisational nostalgia combines idealisation of the past with a symbolic enrichment-mythologisation (Gabriel 2000). One of the pioneers of this was the sports shoemaker Nike, which started a storytelling programme in the 1970s. Storytellers at 'Nike University' concentrated on innovation and heritage, telling how Coach Bowerman needed better shoes for his team and started experimenting (Ransdell 2000). 
Nokia has also been a popular subject for the business world. One measure is the number of Harvard Business School case studies, an educational tool that presents the greatest challenges confronting companies. Up until January 2020, there were 46 studies related to Nokia. This is not much compared with studies concerning American giants like Microsoft (250 case studies) and IBM (135)—not to mention Apple (376). Still, the name of Swedish electronics corporation Ericsson cropped up only 14 times. Studies about Nokia cover such matters as strategic choices, methods of cooperation, subcontracting, marketing, patent management and the challenges of continuous success and overcapitalisation, meaning too much money on the balance sheet.

Not surprisingly, the few case studies undertaken after 2011 have titles such as 'The Rise and Fall of Nokia' (Alcacer, Khanna \& Snively 2015) or 'Nokia: The Burning Platform' (Alcacer, Khanna \& Furey 2011). Probably the best example of this educational logic is the removal of case studies on the success of Enron after the company collapsed, and the introduction of a new species of case studies on 'the ethical and accounting issues posed by Enron's misadventures' (Broughton 2009).

In studies of Nokia's economic and industrial impact on Finland, the work of Jyrki Ali-Yrkkö (Ali-Yrkkö 2000; Ali-Yrkkö 2001a; Ali-Yrkkö 2001b; Ali-Yrkkö 2008; Ali-Yrkkö 2010; Ali-Yrkkö et al. 2011; Seppälä 2010) and his colleagues at ETLA Economic Research is in a class of its own because of the volume, continuity and quality of studies. ETLA's predecessor was founded by the industry in 1946 and has played an active role in the transformation of the Finnish economy with long-term economic growth as both focus and goal.

Corporate consultants, business administrators, technology experts and economic journalists-all have wanted an opportunity to tell people about this company from the cold north and its incomparable triumph. Nokia gave new self-confidence to the Finns, from the elite to the factory floor. Until Nokia's conquest of the world, Finns lacked future visions to which they could attach 
national identity and symbols. The essence of being Finnish was founded on the past: the spirit of the Winter War (1939-1940) and the Finns' defensive victory against the Soviet Union; 'great men' such as Field Marshal Mannerheim (1867-1951) and composer Jean Sibelius (1865-1957), as well as stories about hunger, hazards and sacrifice (Saari 2000). Then Nokia arrived and put Finland on the world map (Kuisma 1999).

\section{Branding a Nation}

Success stories can be created in many ways. In November 2010, a working group called 'Finland Promotion Board', functioning under Jorma Ollila, Chairman of the Nokia board at the time, published a report on Finland as a brand (Maabrändivaltuuskunta 2010). The report caused a stir at the time because it was only a few years since the previous effort to create a 'Finland brand', and the decision of the Finnish Tourist Board to try to market Finland to the world as 'Credible, Contrasting, Creative and Cool' (Holmén 2009; Laamanen 2013). The diplomatic service, the civil service and in fact the whole nation were urged to tell everyone about the '4Cs'.

The problem with the 2010 strategy was the assumption that a country can create a brand for itself. Rarely has a working group painted itself so quickly into a corner as when Jorma Ollila began the report with the statement that 'Finland is the world's best country'. One problem was that too few foreigners regarded Finland as a paragon. The Finland Promotion Board had only one real piece of evidence for its boast. In August 2010, the US periodical Newsweek had declared Finland to be top of the league (Forohaar 2010). Its criteria were education, health, quality of life, a dynamic economy and political atmosphere.

Finns do have every reason to be proud, but that is not a part of their national identity. The facts speak up for Finland: When the country celebrated 100 years of independence, Statistics Finland (2018) aggregated all the indexes that put Finland on top of the world, the freest, safest, most stable, with the best 
governance, least organised crime, most independent judicial system, best protection of property rights, and so the list goes on.

Looking at Finnish history, the low-key profile makes more sense. The country tried to navigate politically between the Soviet and Western spheres of interest after the Second World War and stay neutral, with Switzerland as the role model. Closely monitored by the Kremlin, Finnish decision-makers tried to avoid any controversy that might upset Soviet leaders, even positive events. 'No news is good news' was considered the best strategy (Brander 2019). One can imagine the shock and boost to the national ego when, in 1988, Nokia offered Finns the chance to become 'owners of Europe', as the biggest ever share issue in Finland to date was marketed (Mäkinen 1995). In contrast with the post-Second World War strategy of keeping their heads down, Finns now entered into a completely new era.

A British consultant on national branding, Simon Anholt, provided a small contribution to the Finland brand. Anholt had made a fortune with marketing concepts intended for regions and nations. (Finland paid Anholt $€ 150,000$ for just a few days of work.) Anholt had worked extensively in Sweden and observed the endless discussion that preceded any decisions there. Finland was the opposite. In an interview with the Finnish current affairs magazine Suomen Kuvalehti, Anholt commented that if he had a problem, he would invite a Finn to solve it (Ängeslevä 2010). A Finnish think tank, Demos, helped the promotion board to write their report. Demos translated Anholt's image into something reminiscent of a taciturn and unemotional plumber, who travels around the globe with their toolkit to settle almost any major problem, including drought. Taking phone calls from the four corners of the world, the plumber replies: 'Consider it solved.' This was to be the way of selling global investors and tourists on the legend of a clean, efficient and practical country. Finland was branded as the Silicon Valley of social innovations.

The prescription was strongly criticised and even ridiculed by the Finnish media and public and was soon forgotten, but this is brought up as an example of how life appeared in Finland some 
years ago-and how much the economic recession from 2008 onwards has changed Finland, psychologically, culturally, economically, politically and socially.

Among the Nordic countries, Finland has had the greatest difficulties in balancing state income and spending after the economic recession which began in 2007 (Valkonen \& Vihriälä 2014). Even Iceland, wrecked by a banking crisis, made a quick comeback, while Finnish economic growth even in early 2016 was the slowest in the euro area after Greece, far from the rate of 4 to 4.5 per cent in 1993, when Nokia was booming. In December 2019, Finland had still not recovered fully from the economic recession (Rehn 2019), and the transformation after the collapse of Nokia's mobile phone business was still under way.

In just a short period of time, from 2008 to 2013, Finland changed from being the economic hero of Europe to a potential problem state, suffering from unemployment and runaway national debt. Nokia was part of the reason. An impending deep crisis in the Finnish social system was masked until 2009/10 by Nokia's glorious success (although Finnish exporters were also helped by strong world demand).

In 2007, when Nokia recorded the largest profit in its history, the Finnish government fostered a two-year labour market agreement that gave wage-earners pay rises of 8.5 per cent. This had a destructive effect on the economy, especially on the cost competitiveness of export industries, as anticipated by a Bank of Finland analysis in 2009 (Honkapohja et al. 2009). According to one elite account, Finland had become a prisoner of its own success, just like Nokia. One well-known Finnish businessperson summarised the Nokia effect in an anonymous interview as follows: 'The Finns were suddenly full of themselves. Social renewal came to a halt. It was rather like modern Norway, with the difference that oil is still worth something. Finnish politicians lost all sense of urgency about reform. The consequences have been unpleasant.'

As shown later in the book and also noted by Sölvell and Porter (2002), the groundwork for Nokia's success was laid in policy changes in the 1970s and 1980s. If it takes as long to 
reshape the Finnish economy, the decisions of the present government will not be felt until 2040-45. It seems a rather distant prospect.

The crisis of 2008 in Finnish public spending was entirely unanticipated. In the autumn of 2007, the Financial Times published a fairly unflattering view of the Finnish economy (Ibison 2007) in a supplement based partly on a McKinsey report published the same year. The Financial Times painted a picture of a country at the crossroads facing momentous and difficult decisions, and pointed out that economic growth had disguised deep structural problems. Finland's taxes were high, wages were low, purchasing power was weak and it was difficult for the country to attract immigrants to redress demographic distortions. The largest daily newspaper in Finland, Helsingin Sanomat (2007), took umbrage and managed to find four factual errors in the 12-page supplement, also questioning how reporters based in neighbouring Stockholm could know anything about Finland anyway. The response illustrates the inability of the Finnish elite, including journalists, to anticipate negative events.

Ibson's assessment in the Financial Times was published the same year as Nokia reported record profits, and thus came a year before the financial crisis hit Finland. It can be taken as a textbook example of how people in power can grasp the problems, but collectively hide their heads in the sand, a phenomenon that will be returned to later in this book.

A similar example is a report published in 2008, entitled A Fugitive Success: Finland's Economic Future (Sabel \& Saxenian 2008). It was commissioned by The Finnish Innovation Fund Sitra. ${ }^{1}$ The authors are Professor Charles Sabel (Columbia University) and Professor AnnaLee Saxenian (UC Berkeley). The report's criticism of the structure of power in Finland, including the Finnish Funding Agency for Technology and Innovation (Tekes, since 2018 Business Finland), ${ }^{2}$ was scathing. Finnish corporate management was too top-down, it said. Nokia was an impenetrable company that discouraged fruitful discussion; it amounted to little more than a production structure. 
Nokia's history of successful reinvention, from paper pulp and rubber boots to electronics, telecommunications, and mobile phones, is a constant reminder not to underestimate the plasticity and determination of the company. But the history is an inspiration and a legacy, not an amulet protecting the firm and sector from a world of competitive threats. (Sabel \& Saxenian 2008: 96)

The report proposed that Nokia's management should be more responsive to consumers and create high value-added innovative services and mobile phone applications. Apple and Google were named as Nokia's largest threats. Meanwhile, Nokia executives were loudly disparaging their new competitors.

Sabel and Saxenian (2008) noted that Nokia was continuing to refine management of its complex delivery chain and technology, but was not successfully exploiting the fact that mobile phones were becoming a channel to the internet-at least not as convincingly as Apple and Google. Having ordered the report, Sitra disowned it, says Mikko Kosonen in his interview. The time was not right for a critical evaluation by American experts.

In her interview, AnnaLee Saxenian remembers the case in detail: 'Nokia was more of a traditional hierarchy and inwardlooking. I remember, through a personal network, we got to one of the senior people, but then when he heard what we were thinking, he got very upset and didn't like it.' That person was Antti Vasara, then a senior manager at Nokia, and since 2015 President and CEO of the state agency Technical Research Centre of Finland Ltd (VTT).

In his interview, Vasara says he does not remember exactly what was said in the interview, but adds that Nokia had survived many crises, which made people somewhat insular to critical claims from the outside.

In the same year, 2008, Sitra's president Mikko Kosonen, together with Professor Yves Doz, published an article on 'The Dynamics of Strategic Agility: Nokia's Rollercoaster Experience' (Doz \& Kosonen 2008), which claimed the Nokia was heading towards better times. Three years later, the authors explained their error (Doz \& Kosonen 2011). 
Steven Elop, a Canadian executive, entered the picture in September 2010, when he was appointed the new CEO of Nokia. Elop underestimated the challenge of leading a large global corporation and overestimated his ability to steer a radically new course. Elop sought to reinvent Nokia, but failed for reasons that we will tackle later. In any case, Nokia's attempt to adapt to the new world by switching from electronics manufacturing to developing applications and internet-based services was to be a long and painful journey.

Finland awoke from its long sleep on 3 September 2013, when Nokia announced the sale of its mobile phone operations to Microsoft. The end of Nokia phones was a natural consequence of preceding events: Nokia's inability to modernise and, with hindsight, its catastrophic decision to stop developing its own mobile operating system Symbian and pin all its hopes on Windows Phone, Microsoft's mobile platform.

Nokia's management and strategy were admired by industry experts and competitors alike for 10 to 15 years. More recently, bookshelves have carried a different sort of literature. Finnishbased US journalist David J. Cord documented the strategic errors in 2014, in The Decline and Fall of Nokia (Cord 2014). In the same year, Finnish journalists Pekka Nykänen and Merina Salminen studied and questioned the ability of one of Nokia's CEOs in Operaatio Elop (Nykänen \& Salminen 2014), a book which was later translated to English in a crowd-sourcing operation by former Nokia employees.

Former Nokia employees had by then already taken up their pens. Corporate lawyer Anne-Liisa Palmu (2009) criticised Nokia's merciless working culture and failed organisational reforms. Nokia's former head of design and innovation, Juhani Risku, has also published his views on how the company could have been reinvented (Risku 2010). The book was based on a proposal for corporate development that had been laid before then-CEO Olli-Pekka Kallasvuo, and rejected.

Tomi Ahonen, a consultant who previously worked for Nokia, attacked its management under Elop with his blog Communities 
Dominate Brands (Ahonen 2013) and has been more aggressive than the other authors. Ahonen writes that the decision by Elop and the Nokia board to disparage Nokia's outdated Symbian operating system in February 2011, when the shops were full of Symbian phones and no replacement product was yet in sight, was one of the biggest errors in global corporate history.

A claim to the definite chronicle of the rise and fall of Nokia came in late 2017, with a book by Professor Emeritus Yvez Doz from the French business school INSEAD, Ringtone (Doz \& Wilson 2017), which is based on interviews with the top management who both led the company to the top and were in charge when disaster struck. The book is an exceptional ethnographic study as the managers, including former Chairman and CEO Jorma Ollila and his successor Risto Siilasmaa, have been able to present their views on the challenges they were facing and the path chosen. Doz himself has been a strategic consultant to Nokia for many years and, through that experience, he has better insights than probably any outsider, being at the same time personally part of the process that led to the demise of Nokia. Though insightful and quite critical, Ringtone has an aura of a negotiated account in contrast to Kingdom of Nokia.

Ringtone should be read before one of the most recent books, Transforming Nokia (Siilasmaa \& Fredman 2018), written by the company's then Chairman Risto Siilasmaa with the help of professional co-author Catharine Fredman. Siilasmaa left his position in April 2020.This is a book about corporate management and board work, but also a personal stinging exposure of Ollila's personality traits. If Nokia was the kingdom, then Ollila was the king:

Inside Nokia, he was an almost mythic character-equal parts revered and feared. Jorma cultivated a serious demeanor, usually wearing a conservative dark suit, a stylish but unremarkable tie, and professorial tortoiseshell glasses. He didn't laugh much and rarely joked. In the boardroom, he sat at the head of the polished wood table, his place embellished with a gavel and a silver name plate, an unquestioned ruler on his throne. (Siilasmaa \& Fredman 2018: 14) 
Nokia's male board members always showed up in well-pressed business suits and ties. Siilasmaa notes that he may have been the first man ever to attend a Nokia board meeting without a tie.

Somewhere between 2003 and 2008, the undisputed leader of mobile telephony, Nokia, had become the epitome of arrogant bureaucracy, a toxic management culture of indecision and gross strategic errors. Nokia's people were sometimes unfriendly to officials and politicians. Matti Purasjoki, head of the Finnish Competition Authority until 2004, recalls how, at the end of the 1990s, Anssi Vanjoki, Nokia's head of marketing, burst into his office shouting and cursing. Purasjoki had been making enquiries about the exclusive rights of sellers of Nokia phones, which he thought might contain restrictions on competition. A call to Nokia had already allayed his suspicions, but Vanjoki had been away and did not know this. Vanjoki behaved so aggressively that Purasjoki got security to show him out. The incident may be a sign of how much authority Nokia executives thought the company had.

Nokia is certainly not the first such case or the last; the world is full of both remembered and forgotten business catastrophes. What makes the Nokia case unique is that the company had been such an important part of the Finnish national economy that it could drag the whole country down with it.

\section{Summary of Chapters}

In this section, the chapters of the book will be summarised.

Chapter 1, 'Introduction', deals with the quality or absence of knowledge from an ignorance studies perspective. Nokia was, as it became a global company, tightly knit and fostered a tribal culture much like Facebook or Google in combination with (and an obsession with) not leaking corporate secrets. This obsession was also manifested in a careful strategy of how to share information inside the company and with stakeholders. NDAs were frequently used for guarding information even of little importance. This meant that most of the outside world had little knowledge of what went on in the company. This became a national concern 
when Nokia's strategic problems turned into a question of corporate survival, especially since Finland also was one of the Western countries struck hardest by the financial crisis in 2007 to 2008 . Here, we discuss what the elite on the outside knew about what was going on, what they did not know and what they did not want to know. As things were going well for the company, politicians, civil servants, experts and the media were passing through a happy period of rational ignorance that brutally ended in something resembling apocalypse. Predictions that correctly established the troubled future of Finland were neglected or condemned outright (see Sabel \& Saxenian 2008).

Chapter 2, 'A Nation Ensnared', analyses how top management at Nokia managed to capture the attention of the elite and examines the consequences of this. Looking at elite discourse (Putnam 1976; Robinson 2010; Ruostetsaari 2007: 158-189), the book explains how people in the top positions could exploit the fact that a global company representing the future came from Finland. The heroic and flamboyant epic tale of how CEO Jorma Ollila's team arrived to save Nokia from bankruptcy has been told so often that it has become part of Finnish mythology. It was part of the rhetoric used by Nokia itself in the 1990s. Later, the company was such a large and permanent part of society that it had less need for such storytelling.

Companies aiming at global success in a market economy need a business environment where business and tax policies, laws, regulations, legal protection and government are based on credible and transparent principles. Stability and predictability are vital. Business faces plenty of risks without the extra ones of political and administrative uncertainty. On these grounds, Finland has been a good domicile for Nokia. The country has taken Nokia's interests into account in many ways, sometimes even at the expense of other companies. Finland's small size has been an explicit advantage. In the 1990s, Nokia could not rely on a large domestic market, so, to obtain growth, it had to venture boldly forth into the world. In Nokia's critical years, Finland was a living laboratory, where it could experiment with innovations and 
research on real people. New products, services, standards and operating practices could be tested before putting them on the world market. And Finland also had politicians willing to channel public sector money into supporting the company's success.

Kingdom of Nokia gives examples of the dominating powers that, for instance, meant that members of parliament were only allowed to choose to use mobile phones other than those produced by Nokia in May 2016.

Following the focus on the market economy, decision-makers and journalists distanced themselves from the idea of Finland as a welfare state rather than a global neoliberal ideology associated with pleasing global markets, open borders for the transfer of goods, capital and workers and a focus on internal competitiveness, mainly the price of labour. Global ideas are powerful because their domestic 'translators of neoliberalism' (Ban 2019: 19) make them go local, hybridising global scripts with local ideas. The main concern for politicians, civil servants and journalists alike was that Nokia would leave its small home country and establish new headquarters in London or New York. This threat was discussed widely at the end of the 1990s. In April 1998, Helsingin Sanomat reached its own conclusion: 'Nokia would be wise to stay in Finland, because Finland needs Nokia more than Nokia needs Finland. Keeping the company in Finland is in the national interest, which shows in the very advantageous business environment created for Nokia.' Nokia's management say they never used the exit-option (Hirschman 1970), but the mere existence of the possibility made all stakeholders respond to Nokia's needs.

Chapter 3, 'To the Open Market', explains how Nokia became a global company and the world leader in mobile communications. Nokia was listed on the New York Stock Exchange in 1994, which was an event with unexpected symbolic and practical implications. Gradually, Nokia became a global company adhering to the free market capitalism rules system. To management, large shareholders are faceless; only the board represents them. 'In a quoted company like Nokia there is no such category as shareholders', says a former Nokia executive. 'The real owners are the markets, 
consisting of people who buy and sell shares daily.' In this chapter, we follow Nokia's route to the work of global capitalism and explore its inner workings.

Chapter 4, 'Troubled Media Relations', is an account of how the watchdogs, the media in Finland, struggled to understand and critically scrutinise a global company. The company's bounceback from near destruction in 1991 to 1992 was slowly registered by Finnish journalists and it was only with the confirmation by international media years later that they realised they had an interesting story on their hands. In fact, it was not until 1998 that the Finnish media grasped the great events that had happened before their very eyes. That was the year when Nokia's CEO appeared on the cover of the international periodical Business Week. Nokia endured a troubled relationship with both national and international media, something winner and darling, at other times loser, but a media coverage never really in accord with the reality. One reason for this was probably linked to PR efforts by the company where journalists were invited on free trips to places such as Cannes and Barcelona, where Nokia threw legendary parties. This chapter deals with the value and shortcomings of media and journalists when it comes to predicting the future.

Chapter 5, 'Who Dared Defy Ollila?', focuses on the management methods and personality of CEO and Chairman Jorma Ollila, who is the only truly global business person to come out of Finland. He was Chairman of Royal Dutch Shell (2006-2015), and the top manager at Nokia Corporation for two decades as chairman (1999-2012) and CEO (1992-2006). He is decorated with a number of international honours and awards. Ollila is a dominant and arrogant personality and in this chapter we deal with the consequences of this-for instance, a company board of directors that was kept in the dark and had very little say.

Ollila's particular management style was characterised by an obsession with the public image of him in the media, especially the Financial Times. For many years, he carried a critical piece from the FT in his wallet as proof that he had been right and the newspaper wrong. Important strategic decisions were preceded by 
a careful examination of what possible damage they could do him publicly, especially when risks were involved. Top managers are humans and it is not uncommon for CEOs to lose their temper, but Jorma Ollila's rage went way beyond the usual and included personal attacks on employees, subcontractors, investors, analysts, journalists, politicians and public servants. We use the concept of 'dictator's dilemma' (Wintrobe 2000) to analyse his role.

Chapter 6, 'Politics and Lobbying', captures how Nokia managed politicians and decision-makers-for instance, by paying election campaign money both in Finland and in the United States. After 2000, Nokia stopped large-scale support for Finnish election campaigns. Financial donations to candidates gradually became a nuisance for corporate management, and had to be hushed up for at least three reasons. Firstly, for several years, American shareholders had been saying that the money should be given openly, as it is in the United States. Secondly, the Finnish Companies Act demands that money is distributed only to promote a company's interest, and it would have been difficult to convince a general meeting that election funding was good for Nokia. Thirdly, the individual sums had become pitifully small.

Chapter 7, 'Raining Riches', looks more closely at how Nokia created huge value for the Finnish society, both in terms of money and other forms of capital, such as global impact. In this chapter, we examine surprising financial windfalls in different parts of Finnish society. Nokia produced a monsoon of money at the end of the 1990s. Multimillionaires came thick and fast off its assembly line. Wealth was reallocated in a unique way. As share options enriched Nokia employees, new billions spread throughout society. It has been calculated that capital gains, mostly from Nokia shares sold abroad, generated a full 31 billion euros between 1992 and 2012 (Puttonen \& Ståhle 2014: 279-283). During that period, Nokia shares were one of Finland's main exports. The dividends distributed by the company amounted to another 3 billion euros. The more lasting positive effects relate more to human capital, as Nokia became the breeding ground for a new class of businesspersons, confident, culturally connected to other societies, multilingual and well versed in global business activities. 
Chapter 8, 'Nokialand Is Born', is a study in nation brand building with Nokia in focus. The brand nation was created in global news media and adopted by Finnish politicians, civil servants and journalists. Nokia put Finland on the world map for new technology, quality products, global marketing and brilliant image building. Finnish design, innovation, business, management and technology shared in the success, and the country is still reaping the rewards. Nokia became known as the mobile nation at the forefront of development, where technology could become a natural part of life.

The stories of a fantastic country, forgotten since the Second World War but now back on the map, seemed to know no bounds. In fact, the legends were backed by Nokia's purposeful marketing and in this chapter we will look at some of those efforts.

Here, we also find the untold and surprising story of how Nokia's slogan 'Connecting people' was created. It was not the effort of the $\mathrm{PR}$ and marketing department, but in the form of a handwritten note by a young engineering student who thought those words captured the essence of what Nokia should be. The slogan was later adopted by, for instance, Facebook, which started with the promise to help people connect with their friends. Facebook also copied Nokia's corporate blue colour.

Chapter 9, 'Subcontractors in Crisis', analyses a few traumatic years in Finnish business history. Nokia's success would have been impossible without the close collaboration of hundreds of subcontractors. The subcontractors were ready to die for their client; many realised too late that Nokia was ready to sacrifice them on the global battlefield if necessary. Initially these aides-de-camp were treated well, but, as Nokia made new alliances, they became a burden that had to be abandoned. Most of the around 300 Finnish subcontractors disappeared between 2000 and 2008 when Nokia decided to move its sourcing to China. This chapter sums up the development.

Chapter 10, 'The Fall of Elcoteq', tells the dramatic story of the largest of these subcontractors. Focusing on Nokia's main supplier, the Finnish electronics subcontractor Elcoteq, which was at one time top three in the world, this part tells how a company worth 
billions went bankrupt in just a few years. Parts of this chapter are more reminiscent of a financial thriller than an academic book and certainly contradicts the idea of rational behaviour in business decision-making.

Chapter 11, 'Factory Exodus to China', tells the other side of the story about the death of subcontractors. One of the most important mega trends of the new millennium is the integration of China into the global economic system. Here, readers can gain an insight into an important piece of that trend: the inside story of how the Chinese-Taiwanese manufacturing company Foxconn managed to become Nokia's dominant subcontractor. It starts with the establishment of Nokia in China in the 1980s, then tracing how the company brought the whole country into the global world of mobile telephony technology. By Nokia shifting subcontracting from a number of Finnish companies to one emerging manufacturer in China, Foxconn was able in just a few years to become the world champion. Accordingly, Chinese mobile phone companies have managed to take the world lead in innovation and the focus has shifted from iOS (Apple) and Android (Google) in Silicon Valley to Shenzhen in southern China. Looking at the investments in 5G technology, China has become the world leader in just two decades, which is a remarkable achievement. However, the close links to the Communist Party mean that companies such as Huawei and ZTE have been banned in several countries. The Chinese form of techno-nationalism is impressive, but not without faults.

Chapter 12, 'Shattered Dreams: India', is the story of how digital communication emerged in India. The first GSM call in the second most populous nation was made on a Nokia phone in 1995 and transmitted through a Nokia network. Here, the story of how Nokia transformed India and brought the country into the modern world of telecommunications is told. The chapter includes personal observations from the early 2000s until recently and is updated with information gathered during a field trip to Tamil Nadu in 2015. Nokia left its former employees at the factory in Chennai, mostly women with low socioeconomic status, 
with memories of well-paid jobs and a safe working environment, but also support through the Bridge programme, which helped people via training and funding. Today, India is still an important market for Nokia's networks division.

Chapter 13, 'The Tale of Two Cities', brings the reader to two Finnish cities that were hit particularly hard when Nokia's problems deepened. One of these is the hometown of Nokia, Espoo, the future of which was defined through this global tech company. The other city, Oulu, was struck by a huge amount of layoffs, but quickly managed to get back on its feet. This chapter also briefly deals with the birth city of Finland's mobile industry, Salo, still struggling with mass employment.

Chapter 14, 'The Decisive Year', captures the agony of a year when Apple and Android were about to divide the world of mobile telephony between them. 'Nokia management was like a flight director who sees everything from the tower', says former Nokia director Jean-François Baril in his interview, and continues, 'at some point he must draw conclusions and believe firmly in them, but Nokia could not.' In 2008, Nokia management could have reinvented the company, but failed. Turning the clocks back, we analyse Nokia's position with the help of a wide range of insiders. The readers are provided with a detailed account of the strategic choices, opportunities and strengths available to the company, while it still had a chance to change its direction. The end result? To wait and focus instead on optimising existing processes and fine-tuning operations, with cost control as the main focus. As one informant observes: 'In a situation where important decisions were needed, the CEO decided to redesign the interior of his safe.' The CEO Olli-Pekka Kallasvuo's speciality was corporate finance and cost optimising. The most important decision would have been a time-out and a reinvention of Nokia's business model, but pressure from investors to not lose global market share made this option impossible.

Chapter 15, 'Symbian Crashes', provides readers with a detailed and somewhat technical account of the different options and obstacles faced by Nokia when trying to achieve the leap from a 
hardware corporate culture to a software environment. The mobile phone operating system Symbian became the main problem that brought Nokia down in a very short time. We follow the internal turf fights between middle managers, the struggle to establish an eco-system of apps and services and the failure to develop the new operating systems Maemo/MeeGo and Meltemi. This chapter also includes a list of technological dead ends, instances where Nokia entered new business areas but failed to decide on the road forward, such as the implementation of Wi-Fi and other voiceover IP technologies in mobile phones. This part of the book also captures other strategic shortcomings, such as the inability to decide what to do with wireless networks, WiFi.

Chapter 16, 'Debacle in the United States', analyses how Nokia failed to capture the US market for mobile phones and networks, partly because of its cultural and organisational problems. Nokia was already present in Silicon Valley in the 1990s, but advice from local managers was ignored by top management. Did the iPhone kill Nokia? 'A little bit paradoxically I guess one could say that the iPhone killed Nokia and the iPad killed the Finnish paper industry, but we'll make a comeback.' This quote by the Finnish Prime Minister Alexander Stubb, in an interview for television business channel CNBC on 13 October 2014, sums up what many people tend to believe. He suggested that Apple could be to blame for the demise of Finland's two biggest industries, which led to a downgrade for the Nordic country by ratings agency Standard \& Poor's. However, this book shows that Nokia's problems were not caused by the iPhone or Android, but originated in decisions made many years earlier.

Chapter 17, 'Surrender to Microsoft', captures the development that led to one of the most traumatic events in Finnish history, the sale of the mobile phones division to former arch-enemy, Microsoft. In February 2011, Nokia decided to give up its freedom and surrender to Microsoft's operating systems Windows Phone, a decision that had catastrophic consequences. It hit the nation very hard, both mentally and physically, with a massive number of layoffs. Nokia's management made a huge bet that ended in 
disaster. In September 2013, it managed to dump the massively loss-making phone business into the arms of Microsoft, which ended a 20-year-long history of being at the global top.

Chapter 18, 'Another Future', analyses the 'new' Nokia that focused on networks after the mobile phone business was finally sold to Microsoft. After the sale, Nokia has made some major acquisitions and is now a strong global player in the mobile networks business and 5G technology. Nokia's turnaround is one of the most dramatic corporate transformations in modern history. This chapter looks at the future of Nokia and contains up-to-date developments.

This book is actually the first account of how the top management at Nokia managed to change Finland according to the company's needs. A local, national and global approach to Nokia's impact is provided. It also includes a critical examination of the role of former CEO and Chairman Jorma Ollila that is not present in any other book. It reveals an alternative account of Nokia operations with some facts that until now have been hidden or conveniently forgotten, including a homage to some insiders who were crucial for Nokia's success, but never received any public credit for it. This book provides an international view of Nokia's impact on huge countries such as China and India and a parallel path regarding Nokia and Silicon Valley.

This book is aimed at specialist readers, such as academics who study mobile and digital media, but also for the more general audiences who are interested in technology companies and their history. The aim is to offer a contemporary account and reconsideration of Nokia, what it achieved, what impact it had, why it succeeded and then failed, and what the new horizon and new Nokia portends. This story is told against the backdrop of Finland, a country with 5.5 million inhabitants in the Nordic region. The book can be labelled an institutional history, which is a narrative that records key points about institutional arrangements - new ways of working, and how they evolve over time, creating more effective ways to achieve goals. An institution, in contrast, refers to rules, norms, conventions, incentives and sanctions that 
govern activities, that is, the things that shape behaviour patterns (Shambu Prasad, Hall \& Laxmi, 2006).

For my PhD thesis in 2012, I had already interviewed a number of Nokia and Ericsson employees, as well as outsiders, mainly communications experts, business journalists and analysts. For this book, however, I have received help from a significantly greater number of people. Some of them spoke entirely on the record; others wanted to know what part of the interview would be used and in what connection; and a small number of them insisted on anonymity before they would give their views on Nokia and Finland. I interviewed a total number of 98 people during 2015 to 2019 , not counting another 30 people who contributed information and personal views on the condition that they remain anonymous (see Appendix A: List of Interviewees). Most of the interviewees are men, reflecting the fact that the majority of Nokia's top management, politicians and civil servants, as well as journalists, were male during the period under study. This observation is in line with Jauhiainen (2007), who notes that the technology discourse in Finnish newspapers has been about men, money and mobile phones. Similarly, Vehviläinen (2002) finds that the heroes of Finnish ICT respond to the stereotypical engineer, men with a technical education interested in sports. 


\section{A Nation Ensnared}

\section{Intertwined Interests}

One of the most important stakeholders in the case of Nokia is the state of Finland, indirectly through the state holding company Solidium, ${ }^{3}$ a minority owner in nationally important listed companies aimed at stabilising national ownership. Businesses aiming at global success in a market economy need an environment where business and tax policies, laws, regulations, legal protection and government are based on credible and transparent principles. Stability and predictability are vital. A business faces plenty of risks without the extra ones of political and administrative uncertainty. On these grounds, Finland has been a good domicile for Nokia. Since the end of the 1960s up until around 2013, the country has taken Nokia's interests into account in many ways, sometimes even at the expense of other companies. Finland's small size has been an explicit advantage. In the 1990s, Nokia could not rely on a large domestic market, so, to obtain growth, it had to venture boldly forth into the world. For Nokia, Finland was a living laboratory, where the company could experiment with innovations and undertake research using real people. New products, services, standards and operating practices were tested in Finland before placing them on the world market. Furthermore, Finland had 
politicians willing to channel public sector money into supporting the company's success.

'Nokia has been a central part of Finnish society for more than 100 years, so it has had no choice but to be interested in the dynamics and special features of Finnish society', said Matti Vanhanen, former Prime Minister of Finland (2003-2010) and former leader of the Centre Party, ${ }^{4}$ in his interview. Foreign observers have been perplexed with the special relationship between Nokia and Finland. The Swedish economic correspondent, Thorbjörn Spängs, head of the business desk at Sweden's largest daily Dagens Nyheter, expressed in 2005: 'I wonder whether Nokia was somehow doped up with Finnish state aid because it was so large for Finland. It is just a journalist's suspicion, but surely the company couldn't otherwise have been so successful.' 'What do you mean by doping?' I asked. 'Well, subsidised deals of some sort. Or-I can only speculate-by massaging the statistics.'

I realised then that Finland had made concessions to the logic of a large global enterprise. The process of concessions and building of new institutions lasted 15 years, before Nokia, at the turn of the millennium, grew too large and basically lost interest in Finland. How was Finland compelled to heed Nokia's wishes?

At the end of the 1980s, as a young business journalist, I interviewed Nokia's then CEO Simo Vuorilehto, who led the company from 1988 to 1992. The headline for my published interview, 'Nokia-a State within a State', was appropriate at the time (Lindén 1986). The story explained how the company's executives were familiar figures in the corridors of political power, such as expert committees, and how most of the company's sales were targeted at the public sector as customer of everything from cables to telecom equipment.

Vuorilehto believed that this was a natural and good thing. 'There is a very constructive atmosphere in Finland. Compared with many other countries, Finland's industry has good relations with the public sector', he said. The interview recalled the words attributed to the top man at one of the largest corporations in the United States, Charles Wilson (1890-1961): 'What's good for General Motors is good for America.' 
The expression entered the Swedish lexicon in 1968, when Gunnar Sträng, the Minister of Finance, declared that 'what is good for Volvo is also good for Sweden' (Molander, Östberg \& Kleppe 2019) This came to define the relationship between the Swedish Social Democratic Party and big business (Brors 2015). Finnish political leaders have not said the same about Nokia and Finland in public, but based on the interviews for this book, it is exactly what some politicians and officials believed.

The relationship between the government and the company that had put Finland on the world map seems to be governed by unspoken rules. It could be small matters, such as officials' tendency not to check Nokia's foreign workers' employment permits. Alternatively, it could be major decisions on economic policy or schools such as the University of Oulu designing curricula to please Nokia (Blom 2018). As early as the 1980s, Nokia CEO Kari Kairamo had grown tired of the Finnish education system and had launched his own programme for improving the educational standard of Nokia employees. An engineer could be trained to be an MSc; an MSc to be a licentiate; and a licentiate to be a $\mathrm{PhD}$. The courses took place in universities, but were tailored to Nokia's needs.

Professor Karl-Erik Michelsen of Lappeenranta University of Technology writes that Nokia's own courses were a great challenge to Finnish officials and politicians. Although they understood that innovative companies needed highly trained personnel, Nokia seemed to be competing with the public education system (Michelsen 1996). After Kari Kairamo's death in 1988, Ollila continued to push educational matters because Nokia required thousands of engineers for its development work. Ollila was thinking further ahead. During Matti Vanhanen's term as prime minister (2003-2010), he says in his interview that he was often contacted by Nokia. Without these talks, Vanhanen would not have decided to implement the 2010 reform in which Finnish universities were separated from the state of Finland to become corporations or foundations. Aalto University was created at the same time from the merger of Helsinki University of Technology, the Helsinki School of Economics, and the University of Art and Design, following years of persuasion by Nokia. In the interview, Vanhanen recalls: 
[The university reform] was the strongest sign of Nokia's impact during my term, although it was indirect. I listened very closely to the opinions of Nokia people and discussed how the universities could serve pioneers in technology. Nokia had gained a lot from Finnish universities, but warned that their standard was too low.

Nokia was able to compare Finnish universities with the world's best because the company had research cooperation with hundreds of universities, including Harvard. In the 1990s, Ollila sat on the board of his own alma mater, Helsinki University of Technology (HUT), and was appointed its chair in 2005. Speaking at HUT's centenary celebrations in 2008, he echoed Kari Kairamo: universities needed modernisation to produce higher quality and better results. In the interview, Vanhanen says this is an example of how under Ollila, Nokia tried to promote a vision extending more than a decade ahead instead of seeking piecemeal advantages.

The Nokia recipe for success was based on officials' and leaders' belief that the country and the company had mutual, intertwined interests. 'Nokia pays so much in taxes and employs so many people that of course it's good for Finland', said Suvi-Anne Siimes, the chair (1998-2006) of the Left Alliance, a far-left party, and Deputy Finance Minister in from 1999 to 2003.

Despite her far-left background, Siimes saw no ideological obstacles to the deregulation of telecommunications services, nor to other reforms important to Nokia. After leaving politics, she began a new career as an industry lobbyist. In her interview she says: 'That Finnish politicians were bold enough to open the market to competition was a precondition for the Nokia phenomenon.' Thanks to telecommunications deregulation in the mid-1980s, local phone companies were able jointly to establish a mobile phone operator Radiolinja in 1988, which became Nokia's first GSM (Groupe Spécial Mobile/Global System for Mobile Communications) client and an important testbed for innovations (Lesser 2008).

Nevertheless, the wishes of the operators, Nokia, and the government did not always converge, as the three following examples demonstrate. Firstly, in 2005, the government legalised 
the bundling of phones and subscriptions, previously forbidden, although Nokia did everything it could to prevent this because telecom operators subsidised phone prices through connection plans, thus concealing the actual price of hardware (Tallberg et al. 2007).

Secondly, starting in 1990-1991, Finland distributed network licences on a national basis, which was opposed by Nokia because a pan-European frequency strategy would have been better for its business. As Marko Ala-Fossi and Montse Bonet (2018: 352) ask: 'Why does the small northern state of Finland, one of the European leaders in the development and use of new mobile technologies, have such an aggressive spectrum policy compared with all other member states and with the most recent EC spectrum policy positions?' In 1999, Finland was the first country in the world to grant $3 \mathrm{G}$ spectrum licences - for free in a traditional beauty contest. The company deemed this to be the best way to build the network, whereas almost all other EU countries sold licences through auctions.

Ala-Fossi and Bonet offer an answer to their question: 'Nokia's influence on Finnish society continues to extend beyond the traditional limits as many of the key positions in the government and media system relevant to the spectrum policy are held by former Nokia top executives or their former business partners' (2018: 352).

Thirdly, regarding Finnish broadband, the communications ministry decided in 2007 on a neutral strategy that favoured neither fibre nor wireless, although two Finnish operators disagreed and Nokia objected to any sort of broadband strategy. The end result of the policy to focus on wireless as suggested by Nokia is that, according to Marko Ala-Fossi (2018), Finland has become 'the slow country of internet connectivity'. Because telecom operators obtained their licences at no cost, they saw no need to invest heavily in fibre networks. At least until 2018, connectivity was well below the EU average and many parts of Finland had such lousy access that companies and even farmers needed to rethink their operations. 
Finland joined the European Union in 1995. Harri Pursiainen, the undersecretary at the Ministry of Transport and Communications, began work for the European Commission a year earlier. 'In Brussels they called Finland "Nokialand", he recalls in his interview. 'It was rather insulting, because Nokia had never been our Big Brother. We had close contacts with LM Ericsson and Siemens as well.'

The interests of Finland and Nokia often coincided with those of Sweden and Ericsson, but, with the European Union, things were more difficult. By the end of the 1990s, after the success of the NMT (Nordiska Mobiltelefongruppen/Nordisk Mobiltelefon), Nordic mobile phone standard and the European standard GSM, Nokia and Ericsson were ready for the next stage: third-generation rapid data transfer and calls. The Nordic $3 \mathrm{G}$ dreams turned into a nightmare, however, after Great Britain and Germany decided, in 2000, to maximise revenue from licences by holding frequency auctions. Amid sky-rocketing prices, the winning operators paid a total of around $€ 100$ billion for licences, taking on so much debt that they could no longer afford to invest in network construction. This was a catastrophe for Ericsson, which received 80 per cent of its revenue from networks. At Nokia, the proportion was only 20 per cent, so the immediate impact was less, especially as mobile phones were still selling well.

Nokia and Ericsson had enlisted the help of their governments and contacts in Brussels to try to prevent the auctions, but had failed. Not at home, however. Finland allocated $3 \mathrm{G}$ licences free of charge at the start of the 2000s. The Minister of Transport and Communications Kimmo Sasi said in his interview in 2014:

[I was] initially in favour of auctions because the state budget could have used the money, but after talking about it with officials, I began to understand that it was in Finland's interest to promote Nokia. How else could we become number one in this field in the world?

This is an illuminating example of how even independent-minded politicians had to surrender to Nokia's demands. 
During his long political career in the National Coalition Party, a centre-right political party considered liberal, Sasi was a Member of Parliament, Minister of Transport and Communications (1999 and 2002-2003), Minister for Foreign Trade (1999-2003) and Chair of the Standing Committee on Finance (2011-2015). In Sasi's view, the interests of Nokia and Finland went hand in hand: 'Of course we wanted to promote Nokia's interests: the better things went for it, the better they went for us [Finland].' One concrete example was the special tax imposed on recording equipment like cassettes and video recorders in place since 1984, the revenue from which was distributed among artists. As they developed, mobile phones also became able to record sound and video. 'We realised it would be problematic for Nokia. Phones had to be exempted from the tax', Sasi explained in his interview.

The Ministry of Communications' policies supported a strong mobile telephony sector and corporate investments in new technology. At least in part, this strategy was successful, enticing many major telecommunications companies, such as Ericsson and Huawei, to set up subsidiaries in Finland. But, as a flagship of Finnish industry, Nokia's influence over Finnish leaders and decisionmakers goes back much further. Already in the 1970s and 1980s, for example, Nokia helped shape the education system, universities, research, attitudes towards the European Union, fiscal and tax policies, the labour market and even energy, where Nokia played a role in Finland's embracing of nuclear power (Blom 2018).

Nokia's executives generally kept a low profile, unless vital company interests were at stake. Further, it is important to separate Nokia's own lobbying from the personal ambitions of its longterm leader Jorma Ollila (1985-2012), who was active in debates ranging from road pricing to the obesity of army conscripts, matters not intimately related to Nokia's competitive edge. In any case, Ollila continued along the path charted by his predecessors. 'Nokia was a state within a state and Ollila's body language showed it', said Erkki Virtanen, an administrator at the Ministry of Finance (1978-1995) and Chief of Staff at the Ministry of Trade and Industry from 1998 to 2015. 
Finland was and still is a corporatist country, where major issues are often decided in backrooms between large stakeholders such as corporations, unions and industry associations linked together by common interests (Wiarda 1997). The system may have advantages such as national unity, but it has a broader tendency to cement power and prevent reforms and innovations. In the period when Kari Kairamo was CEO of Nokia (1977-1988), politicians, labour union leaders, journalists and civil servants ate out of Nokia's hand, quite literally. In his interview, Erkki Virtanen recalls how, as a young official at the Ministry of Finance, he used to be invited to Nokia's villa at Båtvik, kept for entertaining guests. Those evenings involved copious amounts of alcohol. Virtanen recalls: 'One evening Kairamo told a group of civil servants that Nokia had decided to concentrate on mobile communications systems, and that a world sensation was in the making. I didn't buy shares at the time. I've regretted it since.'

Jorma Ollila's social relations were certainly as good as Kairamo's, and were handled without copious drinking. After Kairamo, it was time for a more cautious leader. Ollila spoke with decisionmakers in private, by phone or face to face. Martti Häikiö said in his history of Nokia that Ollila handled affairs: '... via personal contacts, not documents. He maintains an extensive network of telephone contacts. His political connections are broad and he is in continual contact with the economic elite at home and abroad' (Häikiö 2001c: 231).

In his interview, Kimmo Sasi recalls Ollila's close interest in tax matters. On one occasion, 'Ollila called and we talked for a while, but we had opposing views and the discussion led nowhere. It was not an analytical discussion. It showed a Big Brother attitude.' Sasi adds that Nokia did not need to apply pressure: 'It was all very simple for me as a minister. If I knew that something was important to Nokia, it was not my job to question it.'

Writing this book, I sometimes struggle to understand to what extent Jorma Ollila defended Nokia's legitimate interests and when he acted as a powerful individual. When government ministers travelled abroad in trade delegations, Ollila often volunteered to accompany them. Ollila was welcomed, because 
his presence meant that more Finnish businesses would take part and that foreign hosts would be keener to meet the delegation. Ollila had been learning how to create and maintain political relations early on in his youth, when he became a member of Finland's Centre Party. With the party's support, he became the chair of the National Union of University Students (1973-1974).

Ollila soon got tired of politics, as he writes in his memoirs:

I had not, however, enjoyed it [politics]; and I was not sociable enough to go out and win votes from strangers. Nor did power structures or power itself interest me enough for me to crave a seat in parliament or a job at the foreign ministry. I simply wanted things to happen-I wanted good things to happen. (Ollila \& Saukkomaa 2016: 56)

Matti Saarinen, who was Ollila's friend during his time in student politics and later Communications Director at Nokia (1985-1994), says in his interview for this book that Ollila stopped playing politics, but maintained his contact with former political allies. Indeed, he has been widely regarded as one of the most influential people in Finland. Former Prime Minister Matti Vanhanen, also a member of Finland's Centre Party, said in his interview that Ollila always understood what was appropriate:

He never lobbied directly on Nokia's behalf. Everything was related to broader and more general motives. We called each other regularly ... and spoke mostly about foreign and European policies. When I travelled abroad and met foreign leaders, we exchanged experiences, views and analyses.

After Ollila became the chairperson of the multinational oil and gas company Royal Dutch Shell in June 2006, their discussions were increasingly about energy. Russia was a common subject as well. Vanhanen points out in his interview that Nokia never made industrial investments in Russia, perhaps on the basis of Ollila's risk analyses. 'He [Ollila] certainly tried to have influence on Russia relations. Those were difficult times because Russia had a 
contract with BP and Shell, but forced them to accept changes in the contract terms in the middle of the contract period.'

Vanhanen assumes in the interview that Ollila had similar connections to Finland's Ministries for Foreign Affairs or Finance, but says Nokia's influence was not discussed between government ministers. His own conversations did not contain anything that was actually confidential, Vanhanen continues in the interview. The most sensitive subjects concerned international relations, especially Russia.

As a politician, Matti Vanhanen is known in Finland for his calm and tightly controlled behaviour, including a tendency to downplay conflicts. His public image has been constructed as both highly ordinary and decent-a good family man and a humble public servant (Laaninen 2005; Paasonen \& Pajala 2010). He obviously also felt ideologically connected to Ollila as in 2003, Vanhanen asked him to become the presidential candidate for the Centre Party (Ollila \& Saukkomaa 2016).

The relations between Jorma Ollila and an earlier Centre Party leader, Esko Aho, during 1990 to 2002 were exceptional. Ollila discovered Aho at the start of the 1980s, when Aho was an unknown politician working for a small municipality in Western Finland. Ollila was the one who introduced Aho to the inner circle of the Centre Party. Aho's political career took off from that point. In 1991, Aho became Finland's youngest prime minister. Aho can be regarded as a political entrepreneur (Schneider \& Teske 1992), whose entry into the world of Finnish politics also brought a fresh approach to innovation according to Henry Etzkowitz at Stanford University (Etzkowitz 2008). During Aho's term (1991-1995), the Prime Minister's Office took direct responsibility for innovation policies. The Science and Technology Policy Council, founded in 1987, under the Ministry of Education but headed by the Prime Minister, launched in 1990 what was, in practice, the world's first national innovation system (Miettinen 2002).

After Aho's political career, he served as Nokia's Vice President for Corporate Relations from 2009 to 2012. The trinity of the Centre Party, Esko Aho and Jorma Ollila, thus lasted for decades. 
Ollila and Aho even spent free time together, travelling to international events, such as the Summer Olympics in Barcelona in 1992, and the Winter Olympics in Nagano, Japan, in 1998. According to a fellow traveller, Tapani Yli-Saunamäki, they sat together on the plane and usually talked sports statistics, their mutual passion.

Finland's prime minister after Aho, Paavo Lipponen from the Social Democratic Party, took office in 1995. By that time, Nokia had become a runaway success. Lipponen has persistently refused to comment on events surrounding Nokia, which he is saving for his memoirs, and he did not want to be interviewed for this book. Lipponen's political secretary during 1995 to 1996, Jorma Westlund, recalls in his interview that Lipponen attended the opening of Nokia factories in the cities of Salo and Äänekoski. 'The Prime Minister had a functional relationship with Nokia management and Ollila.' In his interview, Westlund points out that Ollila had always been in close touch with Finland's leadership, but not in an open or public way.

Ollila's memoirs are modest about his own influence on Finnish industrial policies, education, taxation, research and product development:

I have always followed broader development in society, taking part in public discussions where they touch on the challenges of business life and the problems companies face. I have also taken a close interest in public education at all levels. Many people have interpreted this as a desire to one day take part in politics as an elected representative. (I have never shown any wish to do so, not even as a remote possibility.) (Ollila \& Saukkomaa 2016: 233)

Ollila mentions in passing his conversations with Prime Ministers Esko Aho, Paavo Lipponen and Matti Vanhanen, and how close their opinions were to his. In his memoirs, Ollila says he actively guided the dialogue towards matters affecting Nokia. After consulting business leaders, the Aho government agreed to increase funds for research and product development to 3 per cent of GNP. 'The government undertook to provide a 40 -percent share, with 
the private sector covering the remaining 60 percent' (Ollila \& Saukkomaa 2016: 230).

The target of increased funding for $\mathrm{R} \& \mathrm{D}$ was confirmed by the Science and Technology Policy for Finland, of which Erkki Ormala was secretary and where Jorma Ollila was the industrial organisations' representative. Ormala worked on the council between 1987 and 1999, after which he was hired as Nokia's Vice-President for Technology Policy, overseeing the company's economic and regulatory environment. After Ormala's retirement from corporate life, he was appointed as Professor at Aalto University in 2013.

The Research and Innovation Council, as it is now known, sets directions for state research and innovation policies. It was established in 1987, and Nokia is the only company that has had a permanent seat on the council. Ormala represented Nokia in numerous international industrial organisations, such as Digital Europe, where he was the president from 2008 to 2012 and spent much of his time promoting a single European market in digital products.

Ollila's memoirs tell that there was considerable doubt within the government and among officials about increasing research funding, but that the objective was achieved in 1999. The proportion to be provided by the private sector was then 68 per cent, so the government's share was less than predicted (Ollila \& Saukkomaa 2016: 231). The speed of economic growth had taken everyone by surprise.

Finland's importance to Nokia-and vice versa-has been widely analysed over the years. Ollila saw no problems in the close relationship, expressing it in simplistic terms: 'I was always proud of the Finnish-ness of Nokia. If Nokia's success helped Finland, it was the best psychological salary of all' (Ollila \& Saukkomaa 2016: 257).

In 1996, the Nokia executive team discussed moving the corporate head office abroad, but agreed that the company would remain in Finland unless 'decisive new factors emerge'. The Prime Minister (Paavo Lipponen, Social Democratic Party) and Minister of Finance Sauli Niinistö were made aware of the decision and were informed at the same time that, in Nokia's view, income 
tax should be lowered. The tax was later reduced because of that corporate message (Ollila \& Saukkomaa 2016: 231).

Based on the interviews, it is clear that politicians did their bit of the work. As second Minister of Finance from 1999 to 2003, Suvi-Anne Siimes had to defend decisions that benefited Nokia, such as the elimination of double taxation of foreign shareholders and a continuation of tax breaks for imported employees. In an interview for this book, Siimes said she told Parliament that the first-mentioned decision did not worry her. It was entirely justified that Nokia should pay only 10 per cent tax on its vast profits, although corporation tax was 25 per cent, because most of the profit came from foreign subsidiaries, which had already been taxed in their home countries.

Tax breaks to attract foreign employees were more difficult, Siimes said. 'The law is already in existence so my job is to defend it although I do not regard it as sensible. It may help in individual cases, but it is not fair that other people on the same salary, including people in Nokia, have to pay more tax.' Nokia spent a considerable amount of time and energy lobbying for the law, which ultimately benefited only a few hundred people. '[It] was merely a money-saver for Nokia, so that it did not need to pay higher wages.'

Siimes did not, however, see it as problematic for a member of a left-wing party to defend worldwide capitalism. Perhaps her background in economics helped her grasp business principles. 'I have always been pragmatic, but not so pragmatic as to be completely devoid of ideology. Being a minister requires service. It is not just a question of what I felt was right or wrong. As a minister I had duties towards the state.'

\section{Financial Aid}

Nokia has been both pleasant and onerous for different Finnish governments. 'Nokia financed our research, education and innovation policies in the 1980s and achieved results. Since the mobile business disappeared from the statistics, we have gone downhill 
in this respect', said senior civil servant Erkki Virtanen in his interview.

After the new millennium, the Finnish government has had the ungrateful task of justifying cuts at Nokia, even while the organisation was in constant transformation. When the mobile phone division was sold in 2013, Jan Vapaavuori, Minister of Economic Affairs (2012-2015) from the National Coalition Party, rebuffed demands that he should reclaim aid totalling €123 million, received by Nokia from Tekes, the Finnish Funding Agency for Technology and Innovation, between 2006 and 2013. Vapaavuori's predecessor and party colleague, Jyri Häkämies (2010-2011), took the same line in defending financial support for Nokia in 2012. In January 2013, it fell to a social democrat, the Minister of Labour and Employment, Lauri Ihalainen (2011-2014 and again in 2014-2015, Social Democratic Party), to explain that officials could not have intervened in the decision to transfer over 700 Nokia IT-people to the payroll of Indian companies Tata Consulting Services and HCL Technologies.

The monetary support given to Nokia was and still is a sensitive subject. Officials at the Ministry of Economic Affairs and Employment pondered from time to time whether it was truly the duty of Tekes to finance Nokia's development projects. The same question has been raised in politics and the media, for instance in Helsingin Sanomat at least in 2006 and 2015 (Pietiäläinen 2006; Pietiläinen 2015), although the Tekes agency operates independently under its own administration, and politicians have no formal control over it.

It is worth noting that Tekes' support for Nokia can be divided into two periods. The first was in the 1980s and at the start of the 1990s, when public money was crucial to the company's success. The second period came in the second half of the 1990s, when public money flowed into Nokia to promote innovations by universities and joint enterprises. Each year, Tekes earmarked a certain amount for Nokia, $€ 10$ to $€ 20$ million annually, out of Tekes' budget of $€ 500$ million. The reason was that Nokia's applications were so well formulated that it would normally have received half of the funds being allocated on the basis of their quality. 
The Director General of Tekes from 2000 to 2012, Veli-Pekka Saarnivaara, was criticised by the media for giving vast sums of money to a global company that most certainly could finance its own research and product development (Pietiläinen 2006). Salmivaara says in an interview for this book that his response was that the money did not stay with Nokia, but flowed onwards to universities, as well as small and medium-sized enterprises.

So even though Nokia is credited with the successful development of GSM phones, many others actors such as universities and national $\mathrm{R} \& \mathrm{D}$ organisations played a vital role in the work, as pointed out in Tekes' history (Korhonen \& Kotila 2008). The first Tekes R\&D programme in 1984 was a massive investment in information and communications technology (ICT) in collaboration with Nokia, long before the internet took off. This programme developed information networks that created technical solutions for GSM. Nokia later hired many members of the research team to continue the work, including Juhani Kuusi, the first Director General of Tekes from 1983 to 1995, and Director of Nokia's Research Centre from 1995 to 2003.

The ICT programme previously mentioned combined the benefits of new technology with Nokia's business skills and an existing mobile phones standard, NMT. At the start of the 1990s, Tekes financed another large technology programme led by Nokia, concerning the design and manufacturing of electronics. This project has received less attention than the GSM programme, but its results deserve closer study because it taught the principles of mass production to Nokia engineers. The programme gave the engineers the skills to meet the upcoming explosive demand for mobile phones.

The public money provided for these projects has been crucial. It bears out the thesis of Italian-American economics professor Mariana Mazzucato that high-risk investments in developing innovations are taken by governments rather than the private sector (Mazzucato 2013).

Later, support from Tekes became less important to Nokia and was used entirely for research into new fields for the company, such as nanotechnology. Sadly, this led to few marketable 
products. Nokia research and product development had become ineffective and lacking in commercial applications.

Indeed, the foundations of Nokia's success were laid before Ollila and his team took charge in 1992. There were numerous elements: a radio factory established in Salo in 1928 by two entrepreneurs, Fjalar Nordell and Lauri Koskinen, which later produced radio phones and was taken over by Nokia in the early 1980s; attempts to build a Finnish computer in the 1950s that laid the foundation for data technology; and the development of telephony at the state-owned telecommunications company Televa at the end of the 1960s, a company bought by Nokia to acquire control over the digital transmission technology that developed into to the telephone switch DX200, the company's very successful and profitable device for many years until the product line ended in 2013 (Sandelin \& Partanen 2015).

\section{Nokia and the Nordic Dimension}

Nordic telecom companies are often perceived as competitors in all circumstances. However, the not-so-hidden secret behind the early and successful development of Nordic telecom markets and the success of companies such as Nokia, Ericsson, Telia and Telenor has been the coordination of public efforts, technical standardisation work and systems interoperability. Nokia and Ericsson as successful private technology companies have benefited from the collaboration between telephone operators once dominated by the state and industry. This section will go back five decades in history to find the Nordic dimension of Nokia's success.

The European dimension plays an important role as Nordic companies both within the EU area, and in associated areas such as Norway, benefit from the negotiating power of the economic area. Today's standards form a vital part of European industrial competitiveness policy, but the organisation of standardisation activities is transforming towards 'hybrid selection processes' (Iversen \& Richard 2006: 37), where both markets and competition as well as negotiation between different stakeholders play a key role. This 
means that the involvement of formal committee-based processes and the role of governments is reduced or replaced by marketbased coordination dynamic activities.

The outcome of the corporate influence on technical standards can be directly translated into corporate and societal gains. From a broader perspective, this might also be seen as one of the 'virtuous circles'-interrelated factors that have made the Nordic economies the most competitive in the world, according to Lopez Claros Augusto, Chief Economist at the World Economic Forum (quoted in Iversen \& Thue 2008: 1). Periods of standardisation are also a prominent feature in business history as it is a strong ingredient in 'formative phases' or periods where the play field is defined and rules of the game settled. Looking at the Nordic mobile phone industry, the path dependency can be established to developments taking place in the 1960s-and to some extent even before. At the same time, we can argue that the 'lock-in' is not as relevant, due to the globalisation from the mid-1990s onwards. Lock-in means that 'one choice or action becomes better than any other one because a sufficient number of people have already made that choice' (Page 2006: 88).

Business systems are mainly seen as national economic ecosystems, but the analysis of Nokia and Ericsson needs a regional or international element, as Iversen and Thue have noticed. The most internationalised Nordic telecommunications companies, for instance, are probably more dependent on international and global institutions than on national regulation and policy (Iversen \& Thue 2008: 8). They are involved in a global business where industrial coalitions and logistics weave a complicated network.

\section{The History of Nordic Mobile Telephony (NMT)}

The foundation for strong growth in mobile phone adaption was laid in the early 1980s, with the adoption of a common Nordic transmission standard NMT, the first fully automatic cellular phone system. The specifications of the NMT analogue standard continued into a European common digital standard, GSM, in the 
late 1980s. In more common terms, it can be described as a gradual transformation from wireless transmission of voice with firstgeneration mobile phones $(1 \mathrm{G})$, to voice and data with the second generation $(2 \mathrm{G})$. This means that Nokia and Ericsson were able to build on a knowledge base developed within the framework of Nordic collaboration dating back to the late 1960s (Moen \& Lilja 2005).

The NMT Group was already established in 1969 at the Nordic Telecommunications conference at Kabelvåg, Lofoten. Delegates from Sweden, Finland, Denmark and Norway proposed an initiative which recommended the Nordic telecommunications authorities to consider a common mobile phone system. A Nordic Working Group was established which, with the assistance of various subgroups, specialists and consultants, was able to create the preconditions for a common Nordic system during the 1970s. The collaboration was publicly funded by Nordic governments and comprised the participation of industrial players and technical universities in all the Nordic countries.

NMT inaugurated the Nordic countries' leadership in the worldwide mobile cellular market and provided a critical window of opportunity for both Ericsson and Nokia (Steinbock 2001: 95).

One interesting question is why Nokia and Ericsson emerged as Nordic champions, but similar companies in Norway and Denmark did not, despite the common technical heritage. Storno Radio Copenhagen was originally established in 1947, and was a division of Store Nordiske Telegraf Selskab (the 'Great Northern Telegraph Company'). In the mid-1970s with a shorter name, Storno A/S was a very successful company with a global market share of 25 per cent. ${ }^{6}$ General Electric bought the company in 1976, and sold it to Motorola ten years later. After the corporate acquisition, the brand name Storno disappeared.

Norway was also unable to develop viable telecom manufacturers, despite many attempts. The best effort was by Simonsen Radio (later Simrad), a company delivering fishing technology that had some success developing analogue mobile phones in the 1980s. Lars Thue (2008) notes that there was no lack of trying as most 
of the telecom equipment was bought from local firms, and huge public R\&D resources were wasted on development contracts with the industry (Thue 2008). Nevertheless, the recent success of mobile telecommunications as a service has actually been carried on by Danish and Norwegian operators, while Nokia and Ericsson have disappeared as mass market brands. Telenor, for instance, is a global player in the field.

\section{From NMT to GSM}

The first NMT network was up and running in Sweden in 1981, which travellers are reminded of when they exit the Arlanda airport in Stockholm and are greeted with a sign and a reference to 'the birth place of mobile communications'. Nordic neighbours followed suit, but the mobile phones could not be used outside the Nordic borders of Sweden, Finland, Denmark and Norway, later also Iceland. In the rest of Europe, other operators such as France Telecom and Deutsche Telekom attempted to create their own technical protocols. The standard in the United Kingdom was called TACS; Germany had C-Netz; France used Radiocom 2000; and the equivalent in Italy was RTMI/RTMS. National standards were matters of industrial policy and control of the domestic market.

Most of the European telecom authorities (the European Conference of Postal and Telecommunications Administrations, CEPT) gathered in 1982, to develop a new digital standard GSM; a move primarily promoted by the Netherlands and the Nordic countries - even though the latter were not EU members at the time. At this stage, the European Commission had realised that telecommunications were to play an important part in Europe's industrial future and steps were taken to ensure that national interests would not dominate interoperability and the idea emerged that telecom services had to be universal (Glimstedt 2001). A European Telecommunications Standards Institute (ETSI) was formed in 1988. The European Commission moved all work from CEPT to ETSI, which meant that national influence on standards was reduced and replaced by open cooperation with market players. 
The EU Commission had approved the GSM in 1984, and a new standard for Europe was born, but not without a long struggle over different views on the technology needed-broadband-TDMA or narrowband-TDMA.

Both Ericsson and Nokia were technology pioneers and early adaptors. The first GSM call in the world was made in Finland in 1991, using a Nokia phone on a Nokia-equipped network (Steinbock 2001). Steinbock notes on the competitive dynamics of technological standardisation: 'Nordic public policies contributed to a favorable industry environment, but it was companies like Nokia and Ericsson that made the environment a source of competitive advantage' (2001: 110). In short, this shows the strength of Nordic collaboration over the borders, both at the state and industry levels, a platform for conquering the world.

\section{Towards Market-Based Coordination}

Up until the 1980s, standards were an issue for the authorities, but by the end of the 1990s, companies were much more involved in the discussion when new technical protocols were written. The development can also be described as a move away from formal ex-ante standardisation-a common and centralised control of technical standards-to ex-post or de-facto standards, where the world of mobile communications is turning to the market (Glimstedt 2001: 52).

Kurt Hellström, former CEO of Ericsson (1999-2003), says in an interview for this book that telecoms is a business where success is very much dependent on technical standardisation, as this lowers the costs for all companies. This was only slowly accepted by companies such as French Alcatel, which had a cosy relationship at home with France Telecom, and German Siemens in a similar marriage with DPT (later Deutsche Telekom). Both tried to set their own standards, but had to change their minds when the markets were opened up for competition. In his interview, Hellström states that during the 1980s it became obvious that a global common strategy was needed: 'The home markets for 
Nokia and Ericsson were small-that was one reason. We saw it especially clearly when we standardized the third generation systems, Alcatel and Siemens tried, as they did with the GSM, to embed their own solutions.'

The competition forced Nokia and Ericsson to be very good at what they do.

The shift in the late 1990s towards market-based standards and open network protocols was expected to resolve the technical problems of connectivity and interoperability. Instead of a certain standard for wireless transmission, Nokia and Ericsson were focused on using a set of compatible standards, 'a family of standards', and even though the companies concluded that there would never be a $4 \mathrm{G}$ standard, for marketing purposes new Gs are introduced. Now we are already moving to $5 \mathrm{G}$.

\section{Nokia's Influence on Public Policy}

Nokia's influence can even be traced to Finland's accession to the European Union in 1995. In studying the path of social development, political scientists often focus on political parties and formal processes. Tapio Raunio, who has studied party attitudes to European integration, lists six factors that shape party politics: fundamental ideology, the opinions of the party elite, public opinion, relations between government and opposition, external events and international cooperation between parties (Raunio 1999). However, a further factor could be added to the list: corporate interests. Anders Blom (2018) concludes that Nokia became an influential factor of 1990s EU corporatism in Finland.

Nokia had long had European partners and dragged Finland into EU membership, which was ultimately negotiated by a coalition government headed by the Centre Party (of which Jorma Ollila was a member). The party has traditionally drawn much of its support from rural areas, and many of the party representatives were originally sceptical towards the European Union. The Centre Party's Chairman and Prime Minister, Esko Aho, worked hard to change the views of his party colleagues and even threatened 
to leave his position. Aho knew that Finnish agriculture would pay a price, but modern Finland would win the day. Jorma Ollila's influence on his protégé can surely be seen here.

It is difficult to document all the features of Nokia's influence, but the parliamentary archives reveal a certain logic. When one looks at the list of experts interviewed by parliamentary committees on patents, copyright, research policies and education, Nokia stands out. A Nokia representative was almost guaranteed an invitation if the matter under discussion interested the company. According to committee minutes, Nokia made statements on laws and statutes almost 100 times from 1991 to October 2014.

An appearance before a parliamentary committee can be seen as measuring the degree of politicisation of a company. This is certainly true of Finnish state-owned airline company Finnair, which was heard by committees 129 times during the same period. The Finnish Broadcasting Company YLE, controlled by Parliament, was heard 137 times and the state-owned energy group Fortum nearly 100 times (from 1998 when it was established). On the other hand, major corporations like UPM were heard only 39 times, Stora Enso 20 times and Wärtsilä 19 times; the reason for this could be that these companies were represented by their industry associations in hearings. However, Nokia's weight in the Finnish economy was by far the greatest of these.

'Finland is a small country, Parliament listens to experts, and a minister always asks about the interests of companies that could be harmed by a law. Admittedly there were differences in nuance. In the 1990s Nokia had a special position', says Kimmo Sasi in his interview.

Parliament was a worthy partner for Nokia, even for testing new telephones. Around 2001, Nokia's Chief Technology Officer Yrjö Neuvo found himself on a flight seated next to the Speaker of Parliament Riitta Uosukainen (1994-2003) from the National Coalition Party and showed her how to use the phone to work and communicate while on the move. The same year, the thirdgeneration Nokia Communicator 9210 was bought for a group of test parliament members (but not donated by Nokia). Despite its 
weight of nearly half a kilo, it became very popular (Hakkarainen 2009). In an internal pilot project, the Communicator was compared to two rivals produced by Compaq, the iPAQ pocket PC and the GSM-enabled Evo notebook. Among MPs, the Communicator was the clear favourite in the tests. Soon, all interested members of parliament received a Communicator. A survey in 2006 showed that 88 per cent of MPs was using one, keeping digital calendars and synchronising documents with desktop machines (Hakkarainen 2009). Some even wrote their speeches on them. This was years before the iPhone would arrive.

Tarja Cronberg, Minister of Labour during 2007 to 2009, was part of the Nokia test programme. She objected to being forced to keep learning how to use new Nokia models. Even for Cronberg, who has a $\mathrm{PhD}$ in technology, the phones did not strike her as user-friendly. Cronberg recalls in her interview: 'My only use for a phone was to call people. There was one Nokia model where you had to perform eight keypad clicks to make a call. Sitting in a ministerial limousine, with five minutes to spare for four calls, it was infuriating.'

For many years, Nokia mobile phones were the only brand provided for Finland's entire civil service. This was also true for organisations not directly under the government, such as Tekes and the Finnish Broadcasting Company YLE. When the iPhone came to market in 2007, a few 'rebels' bought it and used it alongside their Nokia phone, but Nokia's market share in Finland remained at 80 to 90 per cent of all mobile phones. It was not until 2013 that, according to the market intelligence firm IDC, Samsung overtook Nokia as the most popular telephone brand in Finland (Pitkänen 2013). Nokia's market share in Finland had fallen from 65 per cent in 2010 to 33 per cent by spring 2013. Samsung's share had risen to 36 per cent.

Was Nokia's enduring popularity a sign of patriotism or pigheadedness? Parliament finally decided to cease cooperation with the Nokia brand in May 2016, when Nokia Lumia phones were renamed Microsoft Lumia. Finally, MPs were free to choose iPhone, Android or whatever phone they wanted. 


\section{Influence over Legislation}

Nokia's influence extended beyond government and administration to the courts. From the 1980s to 2005, the company was difficult to challenge legally because it had Finland's largest army of lawyers. Several companies tried to obtain compensation from Nokia for having infringed their rights. Not one case went to court, so it is difficult to evaluate whether the claims were justified.

Nokia's greatest interests were in tax and the rules of business. The company also lobbied strongly for at least one law. 'Lex Nokia' was one of the most controversial legal reforms during 2003 to 2010, after strong lobbying by Nokia for the right of employers to read employees' email logs. One business leader active on the employers' side surmises that the campaign for Lex Nokia was managed directly from Nokia headquarters in Keilaniemi. 'Nokia wanted this. It was partly paranoia, but I can't really criticise them. Better safe than sorry. Today all companies face a genuine risk of data leaks.'

When Nokia decentralised procurement at the start of the 2000s, its security department began monitoring the email traffic of employees. Some of the employees had unusually frequent contacts with competitors and contract manufacturers. Management suspected employees were leaking company secrets, for example, to Microcell in Oulu (later taken over by Flextronics of the United States), and to the Chinese telecommunications equipment manufacturer Huawei. The Finnish National Bureau of Investigation decided that there was no cause for a criminal investigation of the employees, but indicated that Nokia itself had broken the law while obtaining the information. The company was facing charges for illegally spying on its employees, until the prosecutor determined that the statute of limitations had expired.

A former employee of a Nokia subcontractor has their own theory about Nokia's behaviour. 'The company was morbidly scared that some competitor would copy or acquire its skills. Instead of being agile, learning from others and trying to stay ahead, Nokia just built walls between its different operations, and still more walls between itself and subcontractors.' 
Nokia's former Chief Security Officer (2001-2006), Urho Ilmonen, says he wrote the basic text of the law the company promoted, in cooperation with lawyers from the Confederation of Finnish Industry. Ilmonen also met with key civil servants to persuade them that Lex Nokia was necessary. It may be normal to consult with companies affected by new legislation, but it is far from democratic that a company itself takes the initiative and drafts a law. In Finland, laws are generally prepared by civil servants of the appropriate ministry at the request of the government. Since March 2012, an amendment to the Finnish constitution also allows citizens' initiatives to be submitted to Parliament.

The futures researchers, Yrjö Myllylä and Jari Kaivo-Oja, wrote a letter to the editor of the newspaper Kaleva in 2008, and explained that innovation was being stymied by Nokia's dominance and its vertical business model, which tightly controlled the subcontracting chain. Their conclusion was that Lex Nokia would prevent the open exchange of ideas and experiences on which the renewal of business depended. Instead of protecting Nokia, the government and local politicians ought to do everything to increase competition (Myllylä \& Kaivo-oja 2008). These appeals fell mostly on deaf ears.

Finland's leading daily newspaper Helsingin Sanomat deeply mistrusted Lex Nokia and the reason was clear. At the start of the decade, its journalists had been spied upon by the national telephone operator Sonera where management tried to find out who leaked inside embarrassing information to reporters by eavesdropping their phone calls and also calls by board members and employees. The subsequent investigation showed that as many as 7,000 individuals were affected (YLE 2003). This dramatic experience showed that the press had every reason to resent efforts to stop leaks by employees. However, Prime Minister Vanhanen took the view that there was a genuine need to protect intellectual property rights, as it had become possible to copy invaluable research results onto a USB stick instantaneously.

Suvi Lindén, a politician from the National Coalition Party and Minister for Communications from 2007 to 2013, had the ungrateful task of getting the law passed. Lindén said in her interview it was necessary to create ground rules, but doubted whether the law 
would be used much. 'The day when someone asks the Communications Regulatory Authority or the Data Protection Ombudsman to apply the law, there will be dreadful headlines.'

Lex Nokia came into force in summer 2009. The law was overturned at the start of 2015, and replaced by the Information Society Code-a set of regulations for electronic communications. By then, only the Municipalities Association and two companies had obtained permission from the Data Protection Ombudsman to monitor telecommunications traffic. None of these resulted in a police investigation or a court case. Lex Nokia was a useless piece of legislation.

Nevertheless, Nokia influenced the Finnish court system in a broader way. Even in the early 2000s, the company was still giving work to practically all of Finland's major law offices, even if some of the duties were only minor, such as drawing up expert statements. Law offices undertaking commissions for Nokia had to disqualify themselves from representing any client against Nokia. They could also be influenced by the desire to receive future commissions from Nokia. This commercial consideration may have been at least as important in curbing legal action against Nokia.

The scenario was repeated at patent agencies. The largest agencies worked for Nokia, although there were a few exceptions. Seppo Laine Oy (later IP Laine Oy), a leading company for IPR protection, took an early decision not to accept work from Nokia and instead looked after the rights of the US company Motorola. Another agency, Borenius \& Co., served Swedish Ericsson. 


\section{CHAPTER 3}

\section{Towards the Open Market}

This chapter is a brief explanation of the process in which business ceased to be closely regulated and Finland became a genuinely open market economy. Again, Nokia played its part in the process. Post-Second World War Finland is a good example of how businesses, politicians, civil servants and universities, working together, can be development drivers.

The Finnish economy, long dominated by agriculture and forestry, began to change during the 1960s, when the process to become a world leader in innovative and competitiveness began. In 1961, Swedish economist Erik Dahmén wrote a report for the Bank of Finland on how the grip of the country's agrarian economy could be loosened. Inspired by the Austrian-American economist Joseph Schumpeter, who believed that innovations drove economic development, Dahmén recommended investment in research, product development and education (Salo 2007; Tarkka 2007).

At that time, and long into the 1970s, Finnish politicians and civil servants sought inspiration for renewal from Sweden. A Finnish journalist colleague of mine used to joke that press conferences in Finland usually ended with the question: 'And how do they do things in Sweden?'

The Finns dismissed Dahmén's ideas, but they took flight again in 1967, when Klaus Waris, the central bank governor who had commissioned Dahmén's report, became head of the newly 
established state-owned innovation fund Sitra. In the same year, Kari Kairamo, then in charge of international relations at Nokia, began to press for an improvement in national educational levels. It was the start of a period of heavy government investment in research, product development and education.

Many people deserve credit for Nokia's later successes, but I will single out one person in government who played a key role. A social democrat, Ulf Sundqvist, was the Minister of Education (in two successive governments) from 1972 to 1975, when the foundations for Finland's widely admired educational system were laid. Sundqvist was also the Minister for Trade and Industry in 1981, when a committee was established that reformed university research, discussed further below. One of the committee's members was Kari Kairamo, by then CEO of Nokia.

The government took a policy decision on technology in August 1982 that affected universities. New universities were to be created in new towns and ground rules were laid down for cooperation between universities and companies. Research commissions were henceforth to be handled by the state's own technical research centre VTT instead of universities. 'Commissioned research at universities had been problematic, especially in Helsinki, because outsiders didn't know who was commissioning what. We decided to replace it with an open, transparent system', Sundqvist recalls in his interview. 'It created an almighty fuss.' Universities did not appreciate that politicians tampered with what they saw as their academic autonomy. In addition to this clarification of responsibilities came another significant change in governance of research and development: the establishment of Tekes in 1983 to facilitate cooperation between business and universities, in other words private and public money (Korhonen \& Kotila 2008). The aim was to combine business and academic interests in a legitimate way. Kari Kairamo had years earlier noticed the rising left-wing politician Ulf Sundqvist and they became friends. It was important for Nokia to build relations with politicians, and Sundqvist, for instance, defended Nokia's ambition to bring nuclear power to Finland. However, it should be noted that Kairamo feared that 
socialism would gain a grip over Finland and socialising with young politicians from the radical left was a way of preventing that development. For instance, after Kairamo's death, an annotated party programme from 1975 for the Social Democratic Party was found in his belongings where he had underlined the party's aim to make Finland a socialist state (Häikiö 2001a: 217).

The formation of Telenokia at the start of the 1980s is perhaps the most important single episode that explains how Nokia managed to conquer mobile phone markets. In the 1970s, the government had tried to establish a native electronics industry, setting up a factory named Valco to produce cathode ray tubes for televisions. The business failed miserably and was shut down by the then Minister of Trade and Industry, Ulf Sundqvist. Instead of pursuing the idea of a state-owned electronics industry, Sundqvist also sold the state's share in the telecommunications company Televa in 1981.

The buyer of Televa's shares was Nokia, and thus, Telenokia was born. Televa had had its roots in the communications technology department of the Ministry of Defence. The company's knowhow was critical for future digital telephony because it had developed a digital telephone exchange, the DX 200. This became the basis for Nokia's later triumph (Sandelin \& Partanen 2015).

\section{Opening up the Finnish Economy}

At the start of the 1980s, Finland's economy was dominated by banks and export-oriented manufacturing companies. Their interests were often considered first by the government, and their decisions were taken behind closed doors. One informal pressure group was known as 'the Billionaires' Club'. Its members were the chief financial officers of exporters with a turnover of at least 1 billion Finnish markkas at the end of the 1980s (around $€ 280$ million in 2019 money). This 'club' was an influential force in foreign exchange policy, sometimes working in tandem with the Bank of Finland, sometimes promoting their own interests (Hulkko \& Pöysä 1988). 
The commercial banks had been operating a governmentsanctioned interest rate cartel since 1931 (Autio 1996). Within the cartel, the banks set lending and borrowing rates at levels that suited them. As banks had strict control over loans from abroad, domestic companies were at their mercy. The banks even decided how much dividend could be distributed to shareholders. However, in the 1980s, the economy began to open up. The interest rate cartel collapsed when the government allowed free movement of capital. Young people in Finland today might find it hard to believe that, in the past, the central bank's permission had to be granted to take more than 10,000 markkas out of the country.

Finnish banks resisted foreign competitors as long as they possibly could, until the middle of the 1990s, when commercial banking had fallen on such hard times after the 1991-1993 economic depression that it welcomed the embrace of Scandinavian rivals. One of the few exceptions was the US Citibank, which had a representative office in Finland from 1977 to 1981, and was then allowed by the Bank of Finland and the Bank Inspectorate to establish a subsidiary on the condition that it confined itself to mediating foreign loans to Finnish companies. Citibank also promised not to poach local employees from the two main Finnish commercial banks, Kansallis-Osake-Pankki and Union Bank of Finland (Suomen Yhdyspankki Oy). This opened the door to young talents like Jorma Ollila, who came in from London.

Nokia CEO Kari Kairamo discovered Ollila at Citibank's Helsinki office and hired him in 1985. Ollila was immediately given a major position arranging international finance for Nokia. By 1986, Ollila was negotiating with US-Hungarian magnate George Soros, who was keen to buy stock in Nokia and other Finnish companies. Soros' activity attracted other investors and, by the end of the year, Nokia had a listing on the London Stock Exchange. Kairamo wanted to reduce Nokia's dependence on Finnish commercial banks Kansallis-Osake-Pankki and Union Bank of Finland, which were using their holdings in a mutual power struggle. 
In the 1980s, Nokia was trying to win space for itself from the forestry and engineering companies and banks that dominated Finnish policymaking. A brand campaign by the Finnish Forest Industries Federation produced the slogan 'Finland lives off the forest', which resonated well with other traditional expressions promoting the industrial roots, 'Finland is a land of a green gold' and 'Finland stands on its wooden legs' (Kortelainen 1999). The slogan was a great success, and is still in 2020 frequently used in political rhetoric. However, Nokia needed politicians to direct their gaze towards a more modern world.

In the 1980s and early 1990s, the corporate atmosphere in Finland was stagnant, culturally, politically and economically. Interviewed around this time by Helsingin Sanomat newspaper, Ollila said that a business leader had asked him: 'Why do you bother to work so hard?' The paper's journalist, Juhani Aromäki, said the question had 'a whiff of an antiquated world, reeking of the pungent smell of papermaking' (Aromäki 1995).

Nokia listed on the New York Stock Exchange in 1994, which confirmed that the company had become a global player. This was an important milestone, both practically and symbolically. Ollila could now move on to the next stage, but there were broader consequences. 'From now on, Nokia's market capitalisation was set mainly by mobile phones. It was as if its visibility and valuation had shifted from Europe to the United States', said Martin Sandelin in his interview. Between 1995 and 2000, he worked as Vice President Investor Relations to manage Nokia's relations with American investors.

At Citibank, Ollila had mastered the logic of international financial markets and made a broad range of contacts. These contacts were useful in the 1990s, when Nokia sold off non-core business operations, both before and after the listing. Bidders found themselves up against sleek American bankers, hired by Nokia to extract the best possible price.

Ollila was taking a large risk by concentrating on mobile phones in 1992 and selling off everything else. At the same time, which was realised years later, Ollila was making Finland more 
vulnerable, and together with other decision-makers contributed to the 'fugitive success', an expression coined by Charles Sabel and AnnaLee Saxenian (2008) to describe the country's fortunate development. Ollila has frequently criticised Finland for being risk-averse. At a meeting with business journalists in May 2006, one of Ollila's themes was the desire for security. He pointed out that Finland had emerged from its last recession by restructuring its economy and that risk-taking was what had made the nation wealthy (Lassila 2006b). 'The current debate seems to be dominated by how to guarantee security. Look to the 1990 s for the recipe for success. Modern methods may be different but the mentality should be the same. Somehow, I miss it.'

The downside of Nokia's focus on mobile phones was that the Finnish economy became less stable as a whole. While the Finnish economy enjoyed the rapid growth of the new sector, it became more dependent on the success of one product of one company. In the 1980s, a company was expected to put its eggs in several baskets. Gradually, diversification seemed to become unwise, and the mantra for a company was that it should focus on its core skills, that is, to specialise in one or two areas.

Ollila has also written that he learned business management from Anglo-Saxon exemplars at Citibank, which was a transactiondriven organisation (Ollila \& Saukkomaa 2016). There were other sources of influence. During the 1990s, the workings of a market economy were also drilled into Finnish business leaders and civil servants by international consultancies like PricewaterhouseCoopers. The economic information office TaT, which served as the propaganda wing of business interests, played an important role in this learning process community, as did the Finnish Innovation Fund Sitra. Many business leaders also studied abroad, obtaining MBAs from foreign business schools like INSEAD outside Paris.

The first signs of an emerging market-driven economy could be discerned around 1980, when the formerly state-owned development company Sponsor Oy Ltd revived its strategy to take a more proactive role. One of the key actors was Jan Boethius, a young Finn who had an American business school education and had been working as one of eight people for Boston Consulting Group 
in Germany. Boethius was recruited to Sponsor to implement the financial innovations he had learned, such as dividing potential takeover candidates into three categories: stars (cash cows), dogs and question marks. Sponsor and its daughter company Spontel Oy introduced shareholder activism, together with a number of financial instruments, such as stock options. But Finland was not ripe. Jan Boethius says in his interview:

We realised we needed to change this [lack of business dynamism]. We looked at development companies in Sweden and the venture capital industry in the United States that was going full speed ahead already in 1978. What was missing in Finland were investors, and an exit market and a market for fast growth. We were lacking the conditions.

Boethius, together with his boss Hannes Kulvik, upset the conservative business establishment for several years with aggressive takeovers and consolidation mergers. This is the material for another book on the emergence of the market-driven economy in Finland, but is included here as an illustration of the business environment in the early 1980s and the importance of isomorphism.

British social scientist Nigel Thrift writes of the 'cultural circuit of capital' (2005), meaning the apparatus that disseminates knowledge in a market economy. It is a useful term to describe Finland, where the ideas of global business models and economic renewal have mostly been imports. Ollila himself blamed journalists and the media for market short-termism in Finland. Speaking at the journalists' meeting in 2006, mentioned earlier, Ollila played down his own role:

If we compare modern times with 1985-1986 when I began at Nokia, the stock market now has a far more crucial role. The stock exchange was previously seen in an entirely different way and I am not sure whether it was better or worse. Perhaps both. But here we are talking only about the downsides of quarterly capitalism. (Lassila 2006a)

By the end of the 1990s, Nokia's interim financial reports became indicators of Finland's economic health. Ollila wanted the media 
to concentrate on the longer term and stop publishing daily stock prices. 'The press could print average share prices once a month and assess companies on the basis of their strategy and annual results. The debate would change entirely and the term quarterly capitalism would become meaningless' (Lassila 2006a).

In the same event, Ollila said that business circles had often considered how to escape from short-termism and expectations based on the predictions of analysts. He hoped for a balance between short-term messages and long-term trends. 'Incentive systems and the way in which companies are assessed could well be based on longer periods than the quarter-year' (Lassila 2006a).

It is often said (wrongly, in my opinion) that the main job of corporate management is to maximise shareholder value. Companies therefore exist only to make their owners wealthier. The concept is a throwback to the 1970s belief in free markets and the views of Milton Friedman, a recipient of the 1976 Nobel Memorial Prize in Economic Sciences and leading theoretician of the Chicago School. Friedman believed that there was only one important measure of a company's success: its share price. He presented this idea in The New York Times in 1970 (Denning 2013; Friedman 1970). In Friedman's world, the company does not have shareholders, workers or a social setting.

Nokia and its satellites lived by Friedman's philosophy long after one of the main proponents of shareholder value, Former General Electric boss Jack Welch, had suddenly changed direction. In 2009, he said it is

the dumbest idea in the world. Shareholder value is a result, not a strategy ... your main constituencies are your employees, your customers and your products. Managers and investors should not set share price increases as their overarching goal ... Short-term profits should be allied with an increase in the long-term value of a company. (Denning 2017)

The exaltation of shareholder value lifted executive salaries skyhigh, but shareholders' dividends nonetheless steadily declined. Chapter 7 tells of the share options that made Nokia executives into multimillionaires in the 1990s. 


\section{Share Buybacks}

During 2003 to 2008, Nokia bought back its own shares to a total of nearly $€ 19$ billion. A study by the Finnish statistics authority in 2010 tells that, during the same five-year period, Nokia shareholders received almost $€ 10$ billion in dividends (Forsman \& Savolainen 2010). When a company buys back its own stock, it is often taken as a sign that management is out of ideas, for instance, that it is unable to find new objects to invest in. One exception to the lack of new investments was the navigation company Navteq, for which Nokia paid the exorbitant price of $€ 5.6$ billion in the summer of 2008. This was the largest takeover price in Finnish economic history, although after the acquisition, Nokia kept Navteq management waiting for months to hear what plans it had for the company. It seemed that the decision to buy the company was impulsive and devoid of strategic rationale.

In the words of one Finnish business leader (in an anonymous interview): 'Share buybacks are a poor way of regulating the amount of shareholders' equity in the company ... And the mechanistic repurchase of a company's own shares is ridiculous. Management ought to buy only when it believes that the share is undervalued.' The upper echelon of Nokia did not believe that the share was undervalued. The buybacks were intended to raise profit per share, one of the indicators most closely followed by analysts and investors. When the number of shares falls, profit appears to have risen because profit per share is higher.

Whether Nokia succeeded in maximising shareholder value depends on the period under review. In any case, the strategy was certainly not sustainable. Nokia's share price collapsed from a peak of $€ 65$ in 2000 to $€ 1.33$ in 2012.

Many believed that Nokia's share buybacks were a titanic waste of money; some even suggested it was the biggest business mistake in Finnish history (Kuisma \& Seppänen 2015). The money could instead have been used to modernise business operations with sensible acquisitions or other investments. At Nokia's annual general meeting in April 2005, a group of Finnish foundations, which held a total of 45 million Nokia shares, attacked corporate 
management for share buybacks that had not produced the desired result. Although the company had bought enormous numbers of its own stock since 2003, profit per share and the share price had declined. The board of Nokia was now asking for authorisation to spend another $€ 5$ billion on share buybacks, but was proposing a dividend of only $€ 1.5$ billion.

The criticism upset Nokia Group's CEO, Jorma Ollila, who summoned representatives of the foundations to a meeting in August 2005, to hear his riposte. One of those present later described the atmosphere as 'icy'. Clearly, Nokia's Finnish shareholders did not enjoy the trust of top management.

Nevertheless, buyback practice was common at the time. US economist William Lazonick notes that, between 2003 and 2012, America's 500 largest quoted companies spent 54 per cent of their profits on share buybacks and 37 per cent on dividends. In Lazonick's view, the reason is clear: executive pay was linked mainly to the share price, so executives used every means possible to try to push the price up (Lazonick 2017).

\section{Wages and Employment}

Payroll costs certainly did not contribute to Nokia's decline; the company paid employees less than its competitors did. For employees, the stakeholder value Nokia created for them was about job security, not high financial returns. In Ollila's view, employees should count themselves lucky to be working at Nokia and should concentrate on doing their best for the company. Only then could they expect economic rewards. 'Some of our employees just wanted to grab a slice of the enchanted cake that Nokia had baked for itself ... they didn't experience the self-sacrifice that lay behind the company's initial growth', he explains in his memoirs (Ollila \& Saukkomaa 2016: 265). Instead of thinking about their wages, the employees should think about what was in the interests of their colleagues and the company.

It was official policy at Nokia to pay 5 per cent less than competitors. The company thought itself so attractive and full of exciting 
opportunities for advancement that applicants would settle for less. Year after year, Nokia was listed as one of the most desirable and highly esteemed places of employment. For talented young people who had received technical and commercial training, it offered opportunities for development, an exciting corporate culture and participation in one of the world's most successful companies. But the wages were poor and the working hours long.

Nevertheless, with every new round of layoffs and restructuring, job security seemed less and less valuable. Trade union action among employees was at a low level for a long time, but as participation began to rise after massive staff reorganisations in the early 2000s, especially among senior office staff, Nokia's management became antagonistic towards labour union representatives. According to the investigative journalist Kati Juurus, shop stewards among senior office workers said that management monitored closely the time they spent on union work and issued warnings to some of them (Juurus 2005). During Ollila's term, it was said that the company was reluctant to talk to union representatives. In the television programme by Juurus, the union representative Markku Mattila remembers one meeting with Ollila: 'He quite obviously threatened me, and ridiculed me as the shop steward.'

In one respect, Nokia management deviated from free market liberalism: in how it set wages and conditions. It was strongly in favour of Finland's system of centralised negotiations and opposed to individual or company-level wage settlements (Blom 2018). One anonymous representative of the employers' association side said in an interview: 'If Nokia had gone its own way, it could have afforded to raise its own employees' wages to any level, with a destructive effect on other companies in the sector. We were grateful for Nokia's solidarity' 



\section{Troubled Media Relations}

From the perspective of Jorma Ollila and Nokia's communications department, the best word for Nokia's relationship with the rest of Finland was complicated. One way to define the relationship is to study the public image of Nokia.

Initially, Nokia's top management found it hard to convince the Finnish media of its great achievements in the world. In the early 1990s, the recession, the collapse of the Soviet Union and exposés about revered top bankers encouraged investigative journalists in Finland to challenge accepted figureheads. There were plenty of political and economic scandals; social insecurity often yields juicy stories if someone is willing to do the digging. Amid all the revelations, perhaps journalists ignored Nokia’s growing success, but their silence was also influenced by Nokia's initial unwillingness to talk about itself.

The company's rise to world renown in the 1990s took place without great headlines. It was not until around 1998 that the Finnish media grasped the great events that had unfolded before their very eyes. That was the year when Nokia's CEO, Jorma Ollila, appeared on the cover of the international periodical Business Week.

'We didn't pursue the cover story for its intrinsic value but because it would confirm that Nokia had at last become a globally important firm, Ollila writes in his memoirs (Ollila \& Saukkomaa 2016: 249). Ollila goes on to criticise Finnish 
journalists for not aspiring to the same level as Business Week, and a year later Forbes, in their analyses of Nokia's corporate culture and core. Ollila continues: 'No other articles succeeded so well in capturing the essence of Nokia's company culture. It was perplexing and astonishing that no Finnish journalist even tried to do so' (Ollila \& Saukkomaa 2016: 249).

Ollila received a preview of Finnish press attitudes in 1994, when the business desk of leading daily Helsingin Sanomat visited Nokia headquarters on South Esplanade in Helsinki. Hannu Sokala, a journalist with the paper and a participant of the visit, described later the event in his own book (Sokala 2002: 9): 'The atmosphere was somewhat tense. I had been following Nokia at Helsingin Sanomat for several years, as the company lunged from crisis to crisis. It had received a public buffeting so its reaction to press representatives was not very relaxed.'

According to Sokala, Ollila spoke glowingly about mobile phones, despite any possible doubts the journalists had, and asked how many of them had one. Not a single hand went up. 'You see from this that we have plenty of customers', Ollila commented. Sokala turned to his colleagues and asked how many of them intended to get a mobile phone. Not a single hand went up. Sokala responded: 'You see from this that people don't want them' (Sokala 2002: 9) The episode is very revealing about how Finnish media felt about Nokia and its leadership as late as the mid-1990s.

By 1996, Ollila had taken the role of Nokia's figurehead, while the communications side, generally the Communications Director, issued official statements to the public. This 'spokesperson model' had been created during CEO Kari Kairamo's term, and was copied from the Anglo-Saxon world (Henisz 2017). Finnish journalists disliked having to negotiate with a spokesperson because they were used to talking directly to all decision-makers without the inhibiting gaze of PR people in the same room.

Ollila was happy to give background briefings to journalists, but not all of them were responsive to his ideas. An invitation to a meeting could deteriorate into a recitation of facts and figures or even a mild reprimand. Sometimes it was the precursor to an 
outright scolding if the journalist had shown bad taste by criticising Nokia and its executives. At the end of every year, usually at the beginning of November, all Finnish citizens' taxable income is revealed, searchable by anyone. This is a practice that raises eyebrows around the world and is not appreciated by everyone in Finland (Paddison 2018). Pauli Aalto-Setälä, who was Chief Editor of the evening paper Iltalehti between 2002 and 2004, says that Ollila was seriously annoyed when personal tax data was published. 'The complaining call came not from Ollila but from [Nokia Communications Director Lauri] Kivinen ... Initially these [tax data] reports appeared only in the afternoon press but soon everyone else was publishing them, and everyone got a phone call afterwards, complaining that they should not have been published.'

A legendary example of Ollila's way of dealing with the media dates from 1999. Tommi Sarlin, working for Yliopisto-Lehti (University periodical), wrote of a speech by Nokia's CEO: 'Up close, Jorma Ollila's shoulders appear very narrow. The story was sent to Nokia for fact-checking and came back with a demand that 'the shoulders' should be removed. Chief Editor Pekka Matilainen decided to leave them in anyway. This resulted in protests from Ollila, a reprimand from the rector of the University of Helsinki and a boycott of the periodical by Nokia's advertising department.

Ollila's complaints have been more defensible when journalists have misunderstood the situation. For years, Ollila carried in his wallet a cutting from the Lex column of the Financial Times of 1995 , concerning the company's growing pains, mostly its components crisis, with the conclusion that Nokia had reached the end of the road. In summer 2003, it was the turn of Business Week's Andy Reinhardt (2003) to question Nokia's ability to stay at the top. These articles seem to have provided Ollila with motivationhe took them out from time to time to energise himself (Ollila \& Saukkomaa 2016: 222-223).

To some extent, Ollila's attitude to journalists and analysts is understandable; it is hard to take jibes and criticism seriously if the facts are wrong. Nokia board member Marjorie Scardino, who 
was also chairperson of the board of Pearson, publisher of the Financial Times, advised him not to read the press when things were going either unusually well or very poorly. It is highly likely, though, that cover stories in BusinessWeek and Forbes reinforced Ollila's ego, as well as his status in the elite of global figures of economic influence.

Still, media prognostications can also be criticised on opposite grounds: that they were not critical enough. In 2007, Forbes business magazine ran a photo of Nokia's CEO Olli-Pekka Kallasvuo with a phone to his ear and a story on the front page entitled: 'Nokia. One billion customers: can anyone catch the cell phone king?' (Upbin 2007). By that time, the collapse of Nokia phones was already imminent.

\section{Relationship with Helsingin Sanomat}

For a major corporation, the media is an important channel for spreading information about the company and creating a positive corporate image of it, as an employer or an investment. If Nokia used to be a giant in the economy of Finland, the country's biggest daily newspaper Helsingin Sanomat used to be, and still is, a corresponding giant in forming Finnish opinion. Numerous studies have established the paper's influence on matters such as globalisation (Lounasmeri 2010) and NATO (Rahkonen 2006). In 2014, Maria Pettersson from Helsingin Sanomat calculated that, in over 10 years, the newspaper had published more than 11,000 stories about Nokia, equal to three per day (Pettersson 2014). A deeper analysis of those stories could have been useful here, but, in any case, the number reflects the newspaper's special relationship with Nokia - even a kind of symbiosis (Lindén 2012).

From the mid-1990s until the end of the 2000s, Helsingin Sanomat had its own Nokia correspondent, a journalist specialising in the company, who was routinely granted interviews with senior executives at times of financial reports and major events. Whenever a new Nokia correspondent was appointed, they received an audience. During Ollila's term, most of the initial audience was 
spent telling which previous Nokia correspondent had done well and what had been wrong with their reporting. Ollila also made sure that Nokia correspondents knew their stories would be read with a magnifying glass. The wrong emphasis in a subordinate clause would result in a phone call of complaint, often on Sundays when Ollila had time to read the newspapers from the previous week closely. Actually, 'complaint' sounds too thoughtful, because according to several reporters who received these calls, the Nokia CEO was all rage.

The special relationship between Nokia and Helsingin Sanomat was clear to people even beyond the inner circle. In September 2010, after the announcement that Stephen Elop would replace Olli-Pekka Kallasvuo as CEO of Nokia, Erkki Tuomioja, a prominent Member of Parliament, and Foreign Minister during 2000-2007 and 2011-2015, wrote in his blog:

Nokia has changed its top executive, as long expected. It is major news and, especially in Finland, where Nokia is a dominant national icon. This also shows in news coverage, starting with Helsingin Sanomat, which, in its editorial and news pages, faithfully repeats the tale told by Nokia insiders about why the change was made, and shamelessly sings the praises of the new leadership. It is somewhat depressing to witness the accelerating pace at which Helsingin Sanomat sacrifices its honourable legacy of independent journalism in the service of special interests, business and political. (Tuomioja 2010 [original in Finnish, translated for this book.])

Nokia's chosen channels for disseminating information in Finland were Helsingin Sanomat and the main television news broadcast of YLE, the Finnish Broadcasting Company. The news cast an agenda-setting status and has traditionally attracted a large audience who want to be informed about the most important news of the day, but as with linear television in Europe, numbers are down. Very little is known about whether the media outlets negotiated the choice of news topics. To put the company's media relations into perspective, it is good to point out what the Council for Mass 
Media, a self-regulating committee of Finnish publishers and journalists, has to say about good professional practice: 'Decisions concerning the content of media must be made in accordance with journalistic principles. The power to make such decisions must not under any circumstances be surrendered to any party outside the editorial office' (Council for Mass Media 2014).

Other media faced an uphill struggle to find out what was going on inside Nokia. Pekka Nykänen of the main business daily Kauppalehti, a flagship for the Finnish business community, was one of those who eventually gave up trying. In his interview, Nykänen said it was almost pointless to call Nokia's communications department because the outcome was clear in advance. 'The person who answered would ask if they could get back to me with the answer later, instead of connecting me with someone who knew the answer. When the call-back came, it would be with two or three prepared answers that were unrelated to my question, Nykänen told me in his interview in 2008. 'I have requested five or six interviews with senior management but not received a single reply so I have simply stopped asking. I realise it is hard to get an interview with the chief executive but there are other people there.'

Companies that worked with Nokia were also extremely unwilling to talk to the media and practically panicked when a journalist called. In today's Finnish media reality, it is difficult to grasp how much authority Nokia could command in managing its public image. The role of Kauppalehti as the mouthpiece of Finnish business life counted for nothing.

Helsingin Sanomat did not suffer from these restraints. From the perspective of democracy, it is worrying if the most powerful institution in a country can participate in deciding what the country's most important newspaper writes. Nokia even recommended that Helsingin Sanomat journalists use foreign analysts as their sources because it felt Finnish analysts had a national perspective that was too narrow (Lindén 2012).

On special occasions, however, the staff of other domestic media houses could enjoy information offered by Nokia. Like other major Finnish enterprises, Nokia paid for the foreign trips 
of a select group of journalists, including travel, food, drink and luxury accommodation. The annual fairs at Cannes and Barcelona were particularly desirable destinations. The trips were legendary among journalists, but there was no public debate about them. Helsingin Sanomat says it paid at least the airfares of its journalists, as well as other costs that were easy to calculate afterwards, but allowed its journalists to go on excursions paid for by the hosts. Other media, except for the Finnish Broadcasting Company YLE, allowed the hosts to pay for everything.

The trips are difficult to reconcile with the aforementioned journalistic ethics, which clearly state: 'Journalists must not misuse their position. They must not deal with issues that may lead to potential personal gain nor demand or receive benefits that might compromise their personal independence or professional ethics' (Council for Mass Media 2014).

When the matter was raised in the interview with Hannu Leinonen, Chief Editor of Kauppalehti during 2003 to 2013, Leinonen defended the practice of letting the hosts pay:

They hold press conferences in Europe. If they want to send journalists to them, we go along; everyone else goes too. We have also attended events arranged by their competitors; there is nothing remarkable about it. If they want to put us up at an airport hotel, of course we let them.

In comparison with Sweden, their journalistic policy is unambiguous: 'Do not accept jobs, invitations, gifts, free trips or other benefits - and do not make agreements or other commitmentsthat could cast doubt on your status as a free and independent journalist' (Swedish Union of Journalists 2018).

Thorbjörn Spängs and Peter Fellman from the Swedish daily Dagens Nyheter and the financial newspaper Dagens Industri, respectively, told me in their interviews that, when their representatives joined in trips arranged by Nokia and Ericsson, the costs were paid by the newspapers. Fellman, Chief Editor of Dagens Industri, further explained where the line went: 'Of course we can accept a lunch.' 
There were other differences between Finland and Sweden. Swedish business journalists are not permitted to own shares in the companies they follow and, in some press rooms, ownership of Swedish stock is entirely forbidden. In Finland, the problem was not recognised and many journalists who actively followed Nokia at least previously had shareholdings in the company (Lindén 2012). With Nokia and reporters having parallel interests, concluding that public debate in Finland about the power position of Nokia could not have been very transparent or analytical.

Society, especially regarding financial markets, has a need for positive corporate news (Dyck \& Zingales 2002). The income and pensions of employees depend on jobs; partners want more business opportunities. Municipalities and the government want tax revenue. Educational institutes need career paths for their students. Furthermore, investors want earnings from their shares. The financial sector earns more when share prices rise. There are links among share price, media visibility and product sales, which is why quoted companies want to appear in the press and on television. A rising share price even makes consumers more interested in the company's products, especially in countries like the United States, where households own a large number of shares. A quotation on the New York Stock Exchange was important to Nokia for visibility rather than for obtaining capital. 'In the US, households follow stock exchange events very closely so, when the Nokia share price rose, the credibility of mobile telephones also increased', says Martin Sandelin in his interview.

Consumer interest also increases when the CEO of a company enjoys favourable publicity. The business press, in particular, interprets success as the result of good management, and corporate leaders gladly accept this view as they are portrayed as influential players with pivotal importance. At the same time, their business methods are simplified. News is personified; the media is the last refuge of heroic deeds by corporate managers, 'the great man theory of history' (Golding 1981: 77). While business journalists are part of the circuit of capital (Thrift 2005), they are also members of 'a small exclusive circle' bound by shared values and 
conventions (Davis 2000; Lindén 2013). In essence, this means that journalists often rely on a limited amount of 'institutionalised' routine sources, which are used due to their positions and expertise status, such as spokespersons or organisational communication (Davis 2007; Tuchman 1973). From my own experience as a business journalist between 1989 and 2010, I can confirm that this is even more the case in a small country such as Finland: there are trusted sources that regularly appear in the media and others that are willing to provide background information, but be present publicly.

At the meeting with Finnish business journalists in May 2006, Ollila accused journalists of being short-sighted, seeking sensation and becoming fixated on personalities. 'We are heading towards [making news] more entertaining and personalising it; even media people are concerned about this. The approach was completely different 20 years ago. Amid all of this, I have to say anyway that I have been treated well; I've been able to live a reasonable family life ... Thank you for that' (Ollila 2006).

Nokia senior management had a strong personal interest in favourable publicity because part of their earnings came from share options, which became steadily more valuable as visibility pushed up the share price. Management therefore had a financial reason for suppressing negative news. Economists Alexander Dyck and Luigi Zingales (2002) point out that

all informed parties have a vested interest in a high stock valuation: managers, who hold stock options; employees, whose jobs depend on the company doing well and whose retirement accounts depend on its stock doing well; and analysts, whose fortunes are very often linked to the success of the stock they analyse. If all the sources have an interest in a positive spin, the news coming from them will be clearly biased. (2002: 91)

It is not an issue without wider implications. A longitudinal study by Dougal et al. (2012) shows that the writing of specific journalists has a causal effect on aggregate market outcomes. The risk of 'irrational exuberance', group think and confirmation bias, is a 
phenomenon where news media plays an important role (Shiller 2002). The social dynamics with Nokia and the Finnish press indicates that this was the case. As Finland's most powerful business executive, Ollila had the opportunity to express his opinions on a variety of matters and Nokia was used in the media as proof of the benefits of deregulation and free markets. Janne Tienari, Eero Vaara and Niina Erkama, economic researchers, noted this in their analysis of the discourse around Nokia in the newspaper Helsingin Sanomat: they found numerous framings where the global free market and neoliberalism was glorified (Tienari et al. 2007). Other researchers confirm the conclusion that mainstream media such as Helsingin Sanomat were by and large in favour of a pro-market logic derived from the Nokia discourse (Poutanen 2019). The possibility that Nokia would move its head office out of Finland was discussed widely at the end of the 1990s. In April 1998, Helsingin Sanomat reached its own conclusion: 'Nokia would be wise to stay in Finland, because Finland needs Nokia more than Nokia needs Finland. Keeping the company in Finland is in the national interest, which shows in the very advantageous business environment created for Nokia' (Junkkari 1998). It is difficult to believe that a nation's surrender to a company could be expressed more clearly.

Did the admiration and deference of journalists allow Nokia management and the whole of Finland to live in the bubble for too long? This would be exasperating because, towards the end of Ollila's term of office, it no longer really mattered to the company what was written and said about it in Finland.

Not until the late 2000s did Helsingin Sanomat's relationship with Nokia become more reasonable. For instance, the special era focused only on Nokia ended. Even so, the newspaper continued to be the part of the press that focused most on the shared interests of Nokia and Finland; its economics desk still believed in late summer 2008 that Nokia's position on global markets was unassailable. This miscalculation-shared by most of Finland, including Nokia senior management-was catastrophic. 
Looking from the stakeholder perspective of journalism, reporters want to be part of brilliant success stories in history. Nokia provided Finnish business journalists with opportunities for collective and private pride; it was rewarding to be in the vicinity of such a great company. We could question if this is actually in line with the professional values of journalism, such as the watchdog role (Deuze 2005). 



\section{CHAPTER 5}

\section{Who Dared Defy Ollila?}

At the beginning of the book, Jorma Ollila was named as Nokia Stakeholder Number One. For many years, Ollila was Finland's only real global business leader. This unrivalled predominance was confirmed by his appointment as Chairman of Royal Dutch Shell. Ollila had already been on the board of the Ford Motor Company for years. No question, Ollila will go down in history as one of Finland's best corporate leaders-but also one of its worst. When Nokia collapsed and sold its mobile phone business to Microsoft, many people, from both the inside and the outside, who were interviewed for this book believed that the failure was the result of long-term strategic problems inherited by Nokia's then leadership. Ollila was in command of the company for two decades and the company underlined the importance of its leaders both in public statements and with their pay packets. This surely justifies a study of the man's personal contribution to Nokia.

It took 10 years for Ollila and PR consultant Harri Saukkomaa to put together Ollila's memoirs (in Finnish, 2013, and in English, 2016). Ollila spent hundreds of hours by a tape recorder and Saukkomaa reshaped these and other stories into a book. In the biography, Ollila gives his own assessment of the context of his leadership. However, the preface points out that he is not 'a history researcher nor is my book intended to be an objective description of corporate history' (Ollila \& Saukkomaa 2016: xi). Nokia's 
success, Ollila says, was the product of hard work and lessons learned the hard way, but also the outcome of pure luck.

The heroic and flamboyant epic of how Ollila put together his own 'Dream Team' in 1992-1993 to save Nokia from bankruptcy has been told so often that it seems to have become part of Finnish mythology. When Jorma Ollila was chosen to reengineer the company, he chose a small group of trusted colleagues to help him with the task. He called the group The Five. In addition to himself, these were Olli-Pekka Kallasvuo, Matti Alahuhta, Sari Baldauf and Pekka Ala-Pietilä. In his memoirs, Ollila explains:

Without clear planning or a single deliberate decision our group ran Nokia from 1994 to 2004. All five of us had a similar background: we were all Finns who had grown up in the provinces, studied in Helsinki, and come to work at Nokia. More significant, however, were the differences between us in the way we approached issues, both theoretically and practically. Our group had immense cognitive diversity. (Ollila \& Saukkomaa 2016: 196)

Interestingly enough, it was part of the rhetoric used by Nokia itself in the 1990s which then became the official story told in news reports and academic books. Later, the company was such a large and permanent part of society that there was less need for such storytelling.

Saukkomaa's main job seems to have been to shatter the public image of Ollila as self-confident, arrogant and unable to accept blame. Indeed, the Ollila of the book takes an invigorating attitude to mistakes, his and others. 'Everyone in the company has the right to make mistakes, but never the same mistake twice', was his catchphrase (Ollila \& Saukkomaa 2016: 169), implying that employees are expected to take risks. A risk realised is not a disaster as long as the people and the organisation learn from it. 'Every mistake and failure brings a huge amount of information that can be put to good use' (Ollila \& Saukkomaa 2016: 168).

Despite the self-critical approach, the book has been written on Ollila's terms, shown by the fact that some leaders from Nokia's inner circle are not mentioned at all, which was recognised by 
some people interviewed for this book: either he does not want to give them credit, or he did not find them important. It also gives the impression that Ollila has not accepted his pivotal role in the collapse of Nokia's mobile phone business. In the words of an erstwhile colleague of the former Nokia strongman in 2014 (in an anonymous interview): 'I think Ollila is in denial. He is trying a bit too hard to rewrite history and protect his reputation.'

At the meeting with business journalists in 2006, Ollila said that success did not come without sacrifices. 'The amount of work that was required is often forgotten. No one counted the hours.' But perseverance alone was not enough. His management style was founded on peak individuals, teams and organisations. This is Taylorism, the principles and practice of scientific management and work efficiency (Taylor 1911), named after Frederick Winslow Taylor (1856-1915). It means measuring attainment and rewarding workers accordingly. In Nokia, this translated into managing the company by using objective 'facts': if an employee could not back up an idea with concrete and trustworthy numbers, it would not be accepted. One of the former Nokia employees interviewed for this book says the concept was called 'fact-based management' within the company.

Ollila's own extraordinary characteristics are clear to those who know him. 'Jorma has an extreme persona. He is intelligent, he has a strong morale, he wakes early and works to a precise schedule, one Finnish business leader said in his anonymous interview. Another person, who calls himself a friend, disclosed this in her anonymous interview about Ollila's self-discipline: 'It's inhuman. It's manic. Tennis at six in the morning?' This is certainly a very Finnish opinion: in an American context, this would be considered normal behaviour by an ambitious business leader.

Based on the interviews for this book, I would conclude that although Ollila's performance is legendary, he is not a fount of ideas or a creative thinker. He is a synthesiser of ideas and facts. He solves problems by listening to all the viewpoints and going away to think about them. He then comes back with a fusion that is acceptable to everyone. One of his earliest colleagues, John 
Ankcorn, praises his analytical skills in his interview: 'Jorma has an enormous capacity for handling facts and data.' For instance, stock analysts would face his knack for numbers in conference calls, when they challenged him. In one call I listened in to, he corrected an analyst with a dry, British, 'But certainly my dear Angela, you must know that ...'

Nevertheless, performance-oriented, workaholic leaders are capable of excesses. In competition with others for status or recognition, they can be domineering, scornful and insensitive. Many in Ollila's close circle experienced these characteristics and strong negative emotions they aroused, such as horror. Risto Siilasmaa has actually accused Ollila of creating a culture of fear (Siilasmaa \& Fredman 2018). References to this can also be found in an academic study (Vuori \& Huy 2016; Vuori \& Huy 2018) based on interviews with former Nokia managers, who tell of Ollila's outbursts of rage and the intimidating atmosphere in Nokia.

In particular, top managers and even some board members were unable or afraid to voice their concerns about the severity of the threats and to develop a stronger response to the emerging problems of Nokia during and after 2008. As one of the top managers reflected in his interview on the period from 2007 to 2011: 'A lot of the board members felt that they weren't always encouraged to speak freely [at that time].'

The Nokia top management shared emotions of fear with middle management, but for different reasons: top managers were afraid of external competitors and shareholders, while middle managers were mainly afraid of internal groups, 'including superiors and peers' (Vuori \& Huy 2016: 9). This led to a communication breakdown where top management failed to transmit the severity and existential quality of external threats, while middle managers feared being the bearers of bad news of the organisation's poor state. Their reluctance to share negative information on the middle level upwards meant that top managers could 'develop an overly optimistic perception of their organization's technological capabilities and neglect long-term investments in developing innovation' (Vuori \& Huy 2016: 9). 
If employees around Ollila held their tongues and knuckled under, this raises a significant question about Ollilas exercise and concentration of power: did even the Nokia shareholders dare to defy him? By the start of the 1990s, Nokia had escaped the chains of its two prominent shareholders, the Union Bank of Finland and Kansallis-Osake-Pankki commercial banks. Now Ollila and his executive team had the opportunity to exercise power independently, and their achievements were being assessed only by the share and bond markets, every day and every minute. Nokia's annual general meeting simply confirmed the separation of powers once a year as there was hardly any opposition against management from major shareholders represented by lawyers, even though critical voices from small shareholders could sometimes be heard.

There is an ongoing debate about the benefits of faceless capital versus personal ownership. The latter is associated with longtermism and exemplified by, for instance, the Nordic companies owned by the Wallenberg family in Sweden and the Herlins in Finland. Nokia had a management structure that answered to the market, which worked well during the company's heyday, but became a problem when the business environment changed.

Former Prime Minister Matti Vanhanen gave much thought to the question of ownership while he was Managing Director of The Family Business Network Finland from 2010 to 2014, a community of private companies with family ownership. In Vanhanen's view, Nokia management played a decisive role, both positive and negative, in the company's success. When the mobile phone business was beginning to flourish, its executives were very good at exploiting opportunities, but their gaze should have been farther into the future. Vanhanen says in his interview: 'Operational management needs no more than a company meeting and the mandate of the board, but in some situations it is good to have a purposeful and farsighted owner ... Who owned Nokia?'

That is a good question: Who owned Nokia? To management, large shareholders are faceless; only the board represents them. 'In a quoted company like Nokia there is no such category as 
shareholders', says an anonymous former Nokia executive. 'The real owners are the markets, consisting of people who buy and sell shares daily.'

Without a strong owner, power in Nokia began to be centralised. Ollila's appointment in March 1999 as President and Chairman of Nokia raised many eyebrows. Finnish company law does not permit the same person to be CEO and chairman of the board, so another executive, Pekka Ala-Pietilä, took the formal position of CEO. Matti Alahuhta and Sari Baldauf began to run the two major business areas, mobile phones and networks. Everyone reported to Ollila, who as president had de facto operational responsibility. The model was designed in spring 1997, when the previous Chairman of the board, Casimir Ehrnrooth (1992-1999), announced he intended to step aside. The company's historian Matti Häikiö says that the appointment as president and chairman was in recognition of Ollila's glorious work (Häikiö 2001c), but the key question is whether the board lived up to its responsibilities after Ollila became its chairperson in 1999. Later development will show that the role of the board of directors was mainly to support management and not to question the strategy.

The broader objectives of corporate governance are to protect the interests of shareholders and various other stakeholders. Corporate governance has predominantly focused on the relationship between the management of firm and the board of directors, particularly on separating these two functions for effective professional management (Madhani 2017: 7).

The board at that time was strongly anchored in Finland's financial world, with Iiro Viinanen (former politician for the National Coalition Party and board member from 1996 to 2001) and his deputy Pirkko Alitalo (1992-2000) of the insurance company Pohjola, Vesa Vainio (1993-2008) of the bank Nordea (created after a fusion of Union Bank of Finland and Kansallis-Osake-Pankki), Jouko K. Leskinen (1994-2001) of the insurance company Sampo and Georg Ehrnrooth (2000-2010) of the engineering company Metra. The other board members were Professor Bengt Holmström (1999-2012) of Massachusetts Institute of Technology (MIT), 
Paul Collins (1998-2007) of Citigroup and Robert van Oordt (1998-2004) of Rodamvom, a property company. The only one of these people actually mentioned in Ollila's memoirs is Collins, which can be seen as a measurement of his respect for this particular individual: 'Collins' role at the beginning of the 2000's was notably bigger and more important than appeared in the public' (Ollila \& Saukkomaa 2016: 245). The same attention was not given to his long-time friend, Bengt Holmström, who received the Sveriges Riksbank Prize in Economic Sciences in Memory of Alfred Nobel in 2016.

A journalist with Helsingin Sanomat newspaper, Antti Blåfield, called Ollila after his appointment as president and chairperson of the company to ask about the rationale for the dual role. Blåfield was invited to lunch at Nokia headquarters, where Ollila explained that Nokia had shifted to the Anglo-Saxon management model that had become common in the business world. Blåfield gave his column on the subject the title 'Who controls Jorma Ollila?' (Blåfield 1999). In the column, Blåfield wondered why Ollila was not content just to be chairman, and predicted that the new structure could be problematic if Nokia's success suddenly evaporated. There were dangers in concentrating power, because those around the top man often hold their tongues: 'It is easy to agree with the boss.' Ultimately, however, Blåfield concluded that, even if no one was overseeing Ollila, at least there was an executive team 'strong enough to be blunt with him', by which he meant The Five. Looking at developments a few years later, when Pekka Ala-Pietilä, Matti Alahuhta and Sari Baldauf had left the company and Ollila became something of a dictator, one can conclude that Blåfield was right.

Nokia's board members had expected Ollila to move aside at the end of 2003. He had given the board an envelope containing the names of two people who could take over the reins if something happened to him. One was Pekka Ala-Pietilä, currently in charge of Nokia Ventures, and the other was Chief Financial Officer Olli-Pekka Kallasvuo. Nevertheless, in autumn 2001, the company announced that Ollila would continue until 2006. Ollila 
claims the board was not yet ready to appoint Ala-Pietilä (Ollila \& Saukkomaa 2016: 268).

Kallasvuo had Ollila's confidence and Ollila's memoirs claim that Kallasvuo was part of the Dream Team of top executives, The Five; other insiders say that this was not so, and that Kallasvuo was only Ollila's personal and very loyal adjutant. One of the anonymous interviewees claimed that:

He [Kallasvuo] sat in meetings to be able to tell the boss what was happening in the organisation. Ollila had absolute faith in him. But he was not part of the group that, after the meeting, told everyone else what Jorma [Ollila] had said. The dream team was the bulwark between Ollila and the rest of the organisation.

The other three of The Five-Baldauf, Alahuhta and Ala-Pietilämight have been able to stay in control and keep power decentralised for a few more years, but soon their position was undermined as well. By September 2003, a massive organisational reform was being planned, to take effect the following year. The mobile phone business was divided into three parts. Kallasvuo was now responsible for Mobile Phones (basic handsets); Baldauf became the head of Networks; and Pekka Ala-Pietilä was in charge of the global organisation.

Rotating the functions of top executives might have been a good idea in a static world, but the world of technology was rapidly changing. Nokia's executive team was manned by experts from finance and traditional telecommunications. It lacked someone to lead digital technical development.

The strange thing was that a powerful manager such as Matti Alahuhta, previously head of the Mobile Phone division and seen by many as 'the de facto CEO of Nokia', was given a support function (Doz \& Wilson 2017 91). He had been moved to the strategy department in the reorganisation. His removal from core operations to support functions was Ollila's way to stem Alahuhta's growing influence: one of Ollila's management principles was actually that 'lieutenants should not turn into barons' (Doz \& Wilson 2017). The relationship between Alahuhta and 
Ollila had been frosty for some time already. When Alahuhta was offered a top job at the global engineering company KONE, he leapt at the chance and left in 2004 to turn the company into a corporate success story. Unlike Jorma Ollila, Alahuhta was uninterested in exercising power behind the scenes, says Finnish philosopher and mentor Esa Saarinen. Interviewed by Talouselämä business magazine, Saarinen described Alahuhta as one of Finland's best corporate managers: ' $\mathrm{He}$ is not interested in politics, games or his own success but in the opportunity to build something' (Vuokola 2015).

A Nokia led by Alahuhta would certainly have been different. Alahuhta may lack charisma, but no proof has been found that charismatic management produces successful companies. As American business consultant Jim Collins observes, the most successful corporate leaders are usually entirely unknown to the general public. Charisma is less of an advantage than a burden if the identity of a company's chief executive receives more focus than its goals (Collins 2001).

The resulting leadership vacuum and constant shifting of responsibilities among top executives, especially in the shake-up of 2004, is widely seen as the root of Nokia's subsequent failure. Nokia corporate lawyer Anne-Liisa Palmu (formerly PalmuJoronen), who left the company in 2005, calls the 2004 reorganisation 'a disastrous mistake' in her interview for this book. Even Jorma Ollila admits in his memoirs that he may not have listened enough to his colleagues because, within two years, most of his closest ones had left. 'Perhaps too much tacit knowledge-and also some explicit information-was lost in the reorganisation' (Ollila \& Saukkomaa 2016: 309). The final account comes from Yves Doz and Keeley Wilson (2017), when they note that the reorganisation of 2004 into a matrix model meant that responsibility that had previously been distributed was now delegated upwards. The matrix organisational model was originally pioneered by US computer company Digital Equipment Corporation. In a matrix model, employees report to more than one manager, which is supposed to support cross-functional groups and collaboration. 
Matrix structures are certainly designed to avoid centralisation, build trust and empower people. At the same time, they also tend to slow down decision-making and lead to infighting between groups. Ultimately, organisational restructurings seldom solve the problems they were meant to correct; instead, they create new ones. This was exactly what happened with Nokia's performance: people were taking more and more time to make decisions in committee meetings and less time actually working (Doz \& Wilson 2017: 96). The reorganisation was supposed to restore Nokia's entrepreneurial drive; instead, it made things worse.

One can, however, also argue that the reorganisation was at least partly driven by Jorma Ollila's need for more control, especially over information flows among employees and between managers and subordinates. Here, we introduce the concept of 'asymmetric information' as a management control tool. In business studies, asymmetric information is usually referred to when discussing investing and predictability (Chaney \& Lewis 1995; Miller \& Rock 1985) or, for instance, supply-chain management (Esmaeili \& Zeephongsekul 2010), but less so in terms of strategy or tactics. There was one formal organisation within Nokia and the matrix introduced in 2004, and another coalition invisible and informal, consisting of people trusted by Ollila. For instance, he forbid the CEO Stephen Elop from talking with Nokia board members without he himself being present (Siilasmaa \& Fredman 2018).

In another respect, too, 2004 was a difficult year for Nokia. I attended the Nokia World event in Helsinki in May of the same year, and saw with my own eyes that Ollila appeared exceptionally fatigued. The company had been unable to meet consumer demand for flip phones, the clamshell models that Samsung and others were producing to great success. Anssi Vanjoki had arbitrarily refused to produce clamshell phones, but had to capitulate, and the first of these reached the market six months late. In the long term, he turned out to be right about their weaknesses, but 'if Americans were only interested in buying clamshell models, Nokia had to make them. We at Nokia wanted to be reasonable, but our customers around the world didn't necessarily need to be 
as reasonable as we were in Finland, Ollila writes in his memoirs (Ollila \& Saukkomaa 2016: 303).

In 2003, the mobile telecom operators global trade association had started a rebellion against Nokia, an insurgency that had several battle lines. One line was the lack of clamshell phones, the other was the service business 'Club Nokia', launched in 2000. The operators felt that it was a threat to their own services. The third line was the operating system Symbian, a collaboration between several manufacturers, of which Nokia wanted to take full control.

The power game over who would succeed Ollila began in 2004 . In his memoirs, Ollila writes that Paul Collins, the director who headed Nokia's appointments committee, had asked him for a list of possible successors in February 2005. Ollila wrote down six names, successful managers within the company: Pekka Ala-Pietilä, Olli-Pekka Kallasvuo, Anssi Vanjoki, Pertti Korhonen, Timo Ihamuotila and Mary McDowell. Fairly soon afterwards, however, Ala-Pietilä pulled out, saying that he wanted more time for his family and interests. Others say Ala-Pietilä left the company after Ollila accused him of failing at Nokia Ventures, in the search for companies that would protect Nokia's future.

By spring 2005, the list of possible successors had shrunk to two and in summer, the Nokia board of directors, headed by Ollila, decided to appoint Kallasvuo as the Chief Executive Officer. When the Financial Times covered the sale of Nokia Mobile Phones in September 2013, an article by Andrew Hill blamed Ollila and Kallasvuo for Nokia's problems (Hill 2013). It later published an online correction that Ollila had not been part of the process that led to the appointment of Kallasvuo as CEO in 2006, but this was hair-splitting. People close to the process say in interviews for this book that the choice of Kallasvuo was indeed Ollila's.

By 2005, Ala-Pietilä, Alahuhta and Baldauf had left the company. Soon after, Pertti Korhonen, the leader of the technology division, also parted ways. From the executive team of the late 1990s, there were only three members left: Ollila, Kallasvuo and Vanjoki. One well-informed interviewee said there were many reasons for the break-up. 'For one thing The Five had made an enormous 
amount of money ... from stock options. The options plan may not have been very big by international standards but in Finland it was. They also simply got tired and were [at] each other's throats.'

The departure of key managers and the organisational reform left Ollila in a stronger position and he was even better equipped, as chairman of the board, to take charge of important matters and decisions. Thanks to advanced SAP software-an integrated Enterprise Resource Planning (ERP)_implemented in the mid1990s, Ollila and Kallasvuo had a comprehensive, real-time view of operational matters. Concentrated leadership has its advantages, but it requires that decisions taken at the lower levels are in line with the original instructions, and that top management has sufficient information about what is happening at the lower levels. The dictator's dilemma (Wintrobe 2000) is that, as the degree of control increases, subordinates become less willing to give their opinions, especially if things are going wrong. This problem became an increasingly strong feature of Nokia's company culture as larger and larger obstacles loomed. A good example of the dilemma concerns Nokia's operating system, Symbian, where its archaic nature was obvious and which by 2006-2007 had become a patchwork of software compared to Apple's iOS and Google's Android. In every organisation, it is vital to have employees with sufficient authority and independence to question management's decisions. Kurt Hellström, former CEO of Ericsson, used to be irritated by the general assumption that he had an opinion on everything. In an interview for this book, he explained, 'Whatever you say, no matter how stupid, there are always people and employees who will take it seriously. That is why it is important to have someone who dares to contradict you.' Who dared to defy Ollila after the executive team around him crumbled and only Kallasvuo and Vanjoki remained? Kallasvuo was his lieutenant and Vanjoki did not command Ollila's respect anyway, except for matters of marketing and branding.

Did the board of directors dare? Risto Siilasmaa (Siilasmaa \& Fredman 2018) notes that the board sat silent at the meetings when Ollila spoke, and there was no incentive what so ever to 
have a critical debate about strategy. According to Siilasmaa, the chairman also equated asking questions with venturing into operational matters that the company's management should deal with.

Siilasmaa and Fredman (2018: 53) continue:

The fear of becoming 'operational' is also a weapon to use against any board that might start to 'interfere.' Just blame the board for being too operational. As always, it is very hard to prove the nonexistence of something. Therefore, the board will typically take a step back. When the chairman is the one blaming board members for being operational in asking too many questions, it is truly difficult to change the status quo.

Nokia's board of directors did not voice their concerns about the severity of the threats and the need to develop a stronger response.

Did Kallasvuo dare? Since the mid-1990s, Kallasvuo had often appeared at press conferences alongside Ollila, but journalists or analysts never asked him any questions. Even after the summer of 2006, when he became CEO, he still had to settle for the number two position, taking instructions from the chairman of the board. Revealingly, in his memoirs, Ollila acknowledges his feelings when Kallasvuo took over and he left the CEO's office: 'Now that I think about it, I recall that I never visited the CEO office after that day, though Olli-Pekka [Kallasvuo] did come to mine' (Ollila \& Saukkomaa 2016: 325).

Kallasvuo is described by previous colleagues as pedantic and precise. A former colleague says in his interview: 'A lawyer and a finance man ... should not head a technology company. The money comes when the product works. Juggling cash does not create competitiveness.' Another close colleague described in his interview Kallasvuo's style as 'management by committee'. It was almost impossible to see who was ultimately in charge of what, which was an ultimate result of the matrix organisation introduced in 2004.

Even Ollila mentions his foreboding in his memoirs (Ollila \& Saukkomaa 2016: 340) and his fears were realised in 2008, when 
Nokia closed a factory in Bochum, Germany and moved its machinery to Cluj, Romania, where wages were only a tenth of the German level. The closure directly affected 2,300 employees and thousands more via subcontractors. Kallasvuo and his chief adviser, corporate relations executive Veli Sundbäck, mishandled the affair entirely, which led to a public boycott of Nokia products in Germany. Federal Chancellor Angela Merkel was furious that she had not been warned in advance, and German Finance Minister Peer Steinbrück came up with the expression 'caravan capitalism' to describe Nokia's operations (Gow 2008).

Nokia was forced to provide a total of nearly $€ 200$ million to those dismissed, and North Rhine-Westphalia demanded the repayment of investment subsidies of some $€ 60$ million. Harvard University business researchers Sandra Sucher and Susan Winterberg calculate that, in three years after the crisis, Nokia sales declined by nearly $€ 700$ million and profits by almost $€ 100$ million (Sucher \& Winterberg 2015a; Sucher \& Winterberg 2015b).

For the most part, Kallasvuo's term as chief executive is described as catastrophic. Jean-François Baril, in charge of Nokia's subcontracting, says in his interview: 'When Elop took over, it was after five years of disappointment, five years without the implementation of a single decision about what was to be done. The company was wrecked with disagreements.'

Jorma Ollila's strong sides had included charisma and organisational ability. He wanted and obtained results quickly. What mattered were production logistics and efficiency. Components had to be available and the process had to run without bottlenecks. Ollila achieved his dream and Nokia became a machine. At the same time, the relentless quest for efficiency soured the corporate culture and killed creativity. Ollila and Kallasvuo seemed not to have grasped that competitive advantage does not come from what can be measured and quantified because those things can be copied. True competitive advantage comes from the intangible side of a corporate culture, which is difficult to duplicate.

At the turn of the millennium, well before Kallasvuo's appointment, Mikko Kosonen, head of information management at 
Nokia (part of Nokia's management 1984-2007 and later President of Sitra 2008-2019) and years before he left the company, was already concerned about the mood of complacency. When his own views were ignored, he asked Michael Woolcock, a telecom analyst at Nomura bank, to give a presentation at Nokia headquarters. In May 2002, Woolcock told Nokia executives that they were in danger of falling into Microsoft's arms because the US giant was investing heavily in developing mobile phone software. Looking up from his notes, he saw Anssi Vanjoki, head of the digital convergence unit, leave the meeting early with a look on contempt on his face.

Arrogance was on display again when the iPhone was launched in 2007. The saying goes that people at Nokia, inspired by Tero Ojanperä, referred to Apple as 'that fruit firm from Cupertino' (Hickins 2009). By then, customers, subcontractors and anyone who tried to question Nokia's view of the world had encountered its 'we know best' attitude. There was a strong culture of 'not invented here', which is 'a prescription for second-class citizenship in the global marketplace' (Tidd, Bessant \& Pavitt 2005: 328). There was only one truth, the Nokia truth, with the result that Nokia mobile phones were soon to be outflanked by devices equipped with Apple's operating system iOS or Google's Android. 



\author{
CHAPTER 6
}

\title{
Politics and Lobbying
}

Finland has for years stayed at the top as one of the least corrupt countries in the world and has been touted as a shining example for others (Finland Toolbox 2019). However, all is not what it seems in this northern country and delving into the details we will explore the specific dynamics of another group of stakeholders, politicians, and their relationship with Nokia. We will start in April 2012, when a former Nokia employee, now business man and fixer Tapani Yli-Saunamäki, was sentenced to 3.5 years' imprisonment for gross bribery of politicians, fraudulent bookkeeping and other offences. The Court of Appeal later set aside all convictions except for two cases of dishonesty towards creditors. Much of the money had been collected from companies and distributed to parliamentary candidates regarded as business-friendly. 'If I'd done this work for Nokia, and done it well, I'd have been given a pay rise,' Yli-Saunamäki said bitterly in his interview. 'Now I get jail. Times change.'

What does Nokia, based in one of the least corrupt countries, have to do with bribing politicians? Yli-Saunamäki had been working in the 1980s and 1990s for Nokia, under Harry Mildh (1931-2005), its top lobbyist. Mildh was renowned for his jokes, at which he himself laughed the hardest. The best one recalled by an interviewee is: 'There's no official so dumb as not to be worth paying off?' The joke was obviously so striking, yet memorable, 
that it is still told by business people today and has become something of a legend.

In essence, Harry Mildh was bragging about his own ability to get things done. Mildh stayed out of the limelight and used his social and media connections behind the scenes to promote matters that were important to Nokia. He had a vast budget for entertaining guests, and no luxury was too fine. During the 1980s, Mildh and Yli-Saunamäki went to Geneva in advance of the great fairs held there every fourth year, to eat and drink their way through the menus of the finest restaurants, so that the Nokia team would know what to offer its guests on the evenings of the fair.

Mildh was also pedantic in matters of secrecy. 'We always examined where each person would sit and who would be in the neighbouring seats', Yli-Saunamäki told me in his interview of 2014. 'Would it be possible to talk business; would others overhear? [Mildh] wanted a seating arrangement that was leak-proof. It was a bit theatrical.'

The name of this theatrical drama was 'The Way Finland Worked' and consisted of favours done and favours done in return. Companies, both large and small, bought political influence by making donations to parties of the right such as the Centre Party and the National Coalition Party, while labour unions supported parties of the left, mainly social democrats (Korhonen 2015). Political researchers have documented the financial support system from the end of the Second World War up until the 1970s.

It is well documented in Finland how Nokia CEO Kari Kairamo tried to engineer a non-socialist government for Finland in 1987 and was ready to invest Nokia's money in support of the plan, even in Nokia's own history books (Häikiö 2001b). The leaders of the Centre Party, the National Coalition (conservative) Party and the Swedish People's Party ${ }^{7}$ agreed in writing that, if possible, they would form a government after the next parliamentary election. The agreement is known as the 'strongbox contract', because the document was said to have been kept in a safe at Nokia, under Kairamo's watchful gaze. (When he learned about it, the President of Finland, the social democrat Mauno Koivisto, 
took umbrage and arranged for a different coalition to be formed) (Korhonen 2014).

A former secretary of the Centre Party, Jarmo Korhonen, details the financial and political games that resulted in the strongbox contract in his book Väyrysen valtakunta (English translation, The Kingdom of Väyrynen) (2014), named after the then-leader of the Centre Party. It is the first part of Korhonen's series on dubious election support given to the Centre Party, the Social Democrats and the National Coalition Party from 1959 to 2014. The second book in the series was entitled Maan tapa (English translation, The Way We Do Things (2015). Korhonen spent hundreds of hours digging out the information. The Centre Party has released its archives, but classified the most important documents so that, even as party secretary, Korhonen could not see them all.

Korhonen said he compiled 600,000 documents, mainly internal, from the Centre Party (Hämäläinen 2014). They show the total sums of money spent, but not the names of those who made the donations. Korhonen says (Hämäläinen 2014) that the money was collected from companies by Kairamo and another leading businessman of the era, Casimir Ehrnrooth, who was about to become chairman of the board of directors at Nokia.

A lesser-known fact is that Nokia continued handing out money until as recently as 2000. Matti Saarinen, Communications Director from 1985 to 1994, says in his interview that he helped Jorma Ollila choose politicians to support Nokia's cause, just as Harry Mildh had helped Kari Kairamo. 'The financial support was entirely legal. The expenses were not claimed as tax deductions. They were not published but the auditors and tax officials approved them, and the recipients were from all political directions.'

Matti Saarinen says in his interview that social democratic leader Paavo Lipponen was the only person who ever sent a campaign donation back in 1995. 'An aide said later that Lipponen became annoyed at Nokia for engineering a top government position for [Nokia's former head of international relations] Paavo Rantanen.'

Paavo Rantanen was Finland's ambassador in the United States when he was poached by Nokia in 1988. Jorma Ollila, who became 
Nokia's CEO in 1992, had no use for his services, and according to Matti Saarinen, later arranged for him to take over the top spot in the Finnish Foreign Ministry when Foreign Minister Heikki Haavisto had a stroke in January 1995. Rantanen held the position for 70 days, and became remembered for that in the company as 'Nokia's foreign minister'. Lipponen interpreted the affair as a conspiracy against parties of the left.

Erkki Tuomioja, a veteran of the Social Democratic Party, says in his memoirs (Tuomioja \& Leppänen 2014) that in the early 1990s, he lunched regularly with Harry Mildh in Palace Restaurant, one of Helsinki's finest restaurants at the time. Mildh had left Nokia and was lobbying on behalf of the nuclear power stations of Asea Brown Boveri, later shortened to ABB. Tuomioja was against nuclear power and could not be persuaded. Still, he wrote in his diary after a final meeting that he hoped, mostly as a personal gesture, that Mildh would arrange some small sum for Ahtisaari's coffers. Martti Ahtisaari was the Social Democratic candidate in the upcoming presidential elections, and was ultimately elected as President of Finland in 1994 (Tuomioja \& Leppänen 2014).

Nokia donated 200,000 Finnish markkas to the Ahtisaari campaign, the same amount as it gave to one of his rivals, Paavo Väyrynen of the Centre Party. Jorma Ollila was widening Nokia's financial support to include parties of the left and even the Green League. A Social Democrat, Arja Alho, recalls in her interview receiving money when in local government: 'At the start of the 1990s Nokia was supporting young politicians who it thought would rise to prominent national positions.' At that time, it was not considered problematic to accept money from companies.

The next presidential elections were in 2000. By that time, Tapani Yli-Saunamäki had left Nokia. In 1999-2000, Yli-Saunamäki was serving as head of the presidential campaign of Esko Aho, the leader of the Centre Party. The victory went to Tarja Halonen of the Social Democratic Party, but Aho's narrow defeat was not for a lack of financial resources. His budget totalled 14 million markkas, equivalent to $€ 3$ million in 2018 money. Nokia's name cannot be found among the receipts of the Aho campaign and officially 
Nokia's support consisted only of three new mobile phones provided cheaply to campaign offices. However, in their interviews sources among Nokia's former executives confirm under promise of anonymity that Nokia did give money to Aho, as it did to the other candidates, but no one received very much.

After 2000, Nokia stopped large-scale support for election campaigns in Finland. Petty financial donations to candidates gradually became a time-consuming and distracting nuisance for corporate management and had to be hushed up for at least three reasons. Firstly, for several years, US shareholders had been saying that the money should be given openly, as it is in the United States. Secondly, the Finnish Companies Act demands that money is distributed only to promote a company's interest, and it would have been difficult to convince a shareholder meeting that election funding was good for Nokia. The third reason was that the individual sums had become pitifully small, and hence irrelevant for political influence.

Lauri Kivinen, who held various high positions in communications at Nokia from 1988 to 2007, recalls in his interview that individual candidates standing for parliament received $€ 1,000$ to $€ 2,000$ and prominent candidates perhaps $€ 4,000$. Candidates for the presidency got about $€ 10,000$. At the local government level, politicians in areas where Nokia had operations could count on $€ 500$ to $€ 1,000$. This was the Nokia model created by Harry Mildh and later continued by Tapio Yli-Saunamäki. Although the sums themselves were tiny, Nokia had supported a large number of candidates over the years, and the amounts added up to tens of thousands of euros per election.

The names of the candidates supported, and the sums given, were stored in files to which only senior Nokia executives had access. The files were passed down from one head of corporate communications to the next. When Microsoft purchased Nokia Mobile Phones, the archives were divided and Nokia representatives announced that the lists had been lost. It is a pity if this is true, because this is a significant, supressed facet of Finnish political history. The information I present here is based on verbal interviews. 


\section{US Lobbying}

In the United States, where lobbying and election campaign support are commonplace, money flows are easy to trace because companies must publish them. Expenses paid by Nokia in the United States can be found online and I have compiled them from the Center for Responsive Politics register, maintained by the US Senate (OpenSecrets.org 2020).

Up until 1998, Nokia had spent US\$6.5 million supporting politicians in the United States. Over the next four years, the sum increased rapidly, but by 2002 the company apparently lost interest. It was not until Olli-Pekka Kallasvuo took over as CEO in 2006 that Nokia resumed lobbying US politicians. The peak year was 2008 , when the company invested US $\$ 710,000$ to influence the Senate and the House of Representatives, mainly as regards telecommunications, but also concerning immigration and taxation.

Kallasvuo's aim was to reconquer Nokia's lost market share in the United States, and lobbying was a part of this greater, unsuccessful plan. Lobbying in Washington, DC continued after Stephen Elop replaced Kallasvuo in 2010. Whereas Nokia had previously used professional lobbyists, it now tried to keep political relations in its own hands. The strategy changed again in 2013, when it entrusted its lobbying to the global law firm Alston \& Bird LLP.

From around 1995 onwards, Nokia spent billions of dollars on raising its public profile in the United States, mostly by promoting itself at sports events like the Sugar Bowl, an annual American college football game. Nokia sponsored the Sugar Bowl for 10 years until 2006. Nokia's spending on sports was so high that law professor Bradley Smith, Republican commissioner at the Federal Election Commission, joked that he hoped sponsors would take over political congresses too: 'I look forward to the day ... when Americans can turn on their TVs and watch the Nokia Democratic Convention or the AT\&T Republican National Convention' (Drinkard 2003). AT\&T is America's second-largest mobile phone operator. Since 1998, the company has invested an incredible US\$360 million dollars in lobbying and election support. 
For a Nordic yardstick, we can look to Ericsson of Sweden. Until 2011, it spent less on US lobbying than Nokia, but then rose to the same level. Both Nordic electronics companies are small potatoes compared with the US technology companies Microsoft and Apple, which have spent US\$130 and \$22 million respectively on lobbying and election funding annually since 1998, respectively. Google has spent at least US\$75 million annually since 2003.

\section{Corruption}

The global coalition against corruption, Transparency International, lists Finland among the five least corrupt countries in the world, year after year. In view of the signs of structural corruption in the Finnish system (Koikkalainen \& Riepula 2009; Nazarenko 2019), this should give rise to concern about the state of affairs elsewhere in the world.

The Transparency International ranking comes from combining the results of various surveys. Elites are very well represented in the groups surveyed. As corruption researcher Alex Cobham remarked in Foreign Policy magazine (Cobham 2013), this distorts the final result, because observations by representatives of an established social system cannot be treated as confirmed facts. Juuso Oilinki, a Detective Chief Inspector at Finland's National Bureau of Investigation from 2014 to 2016, said in the summer of 2015 that Finnish structural corruption is difficult to establish using the methods of Transparency International. Most of it remains hidden (Oilinki 2015).

Can Nokia's election campaign funding be called corruption? No, says Swedish political scientist Bo Rothstein, one of the world's experts on the subject. Rothstein says that it cannot be called corruption unless the money is given in return for promises of precisely specified decisions. 'Corruption is support earmarked for a certain purpose', Rothstein says in his interview. He leads the Quality of Government Institute at Gothenburg University.

Nevertheless, Finland as one of the world's least corrupt countries seems to be doing the least in the world to investigate 
corruption. Political researchers have access to data of political funding of politicians stretching up to the 1970s (Korhonen 2014), but how well do we know the links between politicians and building contractors, retail chains and so on?

Nokia has a code of conduct that includes zero tolerance towards corruption. The company says that it will not be involved, anywhere in the world, in bribing officials or elected representatives. Its policy is based on identifying corruption, preventing it and working with others to eliminate it. Nokia's CEO, Rajeev Suri (2014-2020), says that the company operates according to the highest ethical principles and is working to get the whole sector to function in the same way.

The unwillingness of Nokia's current leadership to talk about past election financing is understandable, but it would still be useful to obtain the missing files of recipients in digital form. They would show which of Finland's politicians were considered useful by the country's largest company's management. Election funding ends up as advertising revenue and many journalists are also part of the network of cronyism, so the media avoids critical investigations of election financing. 


\section{CHAPTER 7}

\section{Raining Riches}

One of the happiest groups of Nokia stakeholders were shareholders, or more precisely, those who managed to time their buying and selling right. Nokia produced a monsoon of money in Finland at the end of the 1990s. Multimillionaires came thick and fast off its assembly line. Wealth was reallocated in a unique way. As share options enriched Nokia employees, new billions spread throughout society. Vesa Puttonen and Michael Ståhle calculate that capital gains, mostly from Nokia shares sold abroad, generated a full $€ 31$ billion between 1992 and 2012. (Puttonen \& Ståhle 2014) At the time, Nokia shares were one of Finland's main exports. The dividends distributed by the company amounted to another $€ 3$ billion. Most of the money went to institutional investors, such as Pohjola insurance company, but households are calculated to have received $€ 2$ billion, according to Puttonen and Ståhle (2014). Many individuals became immensely wealthy at the end of the 1990s, and it was a popular pursuit among Finnish journalists to dig out names from the register of shareholders.

Nokia created more than just capital gains. Jyrki Ali-Yrkkö, a Nokia specialist at ETLA economic research institute and Anssi Miettinen of Helsingin Sanomat newspaper have calculated the Nokia effect as being worth at least $€ 100$ billion in Finland between 1992 and 2012 (Miettinen 2014). In addition to capital gains and dividends, the company paid $€ 10.5$ billion in corporation tax during that period. Wages, share options and social security 
payments by Nokia yielded $€ 23$ billion. Moreover, subcontractors created their own capital gains, taxes, wages, share options and social security payments of $€ 31$ billion euros (Miettinen 2014). The biggest beneficiary was the government, but several cities where Nokia had operations-Espoo, Salo, Tampere and Oulualso enjoyed a tax boom.

Many of the 7,000 employees to whom Nokia distributed share options in the 1990s became multimillionaires almost overnight. Their sudden riches created jealousy, which eroded a previous strong sense of solidarity in the company; when someone becomes hugely rich with no particular effort, the neighbour with no share options easily turns cynical. When the share price peaked in 2000, many nouveaux riches left the company and took their skills with them. Then the fabulous gold mine stopped yielding, to the disillusionment of those who had joined the company in the hope of striking it rich. In subsequent years, there were no new option millionaires because, with the share price falling, converting options into shares would only have produced a loss.

In his memoirs, Jorma Ollila rejects the popular idea that share options ruined Nokia's corporate culture (Ollila \& Saukkomaa 2016: 254). Ollila was one of the 50 people who received options as early as 1994, and so was able to enjoy the greatest gains. Several former employees interviewed for this book disagree with him and see share option jealousy as an important reason for Nokia's fall. Why work one's fingers to the bone if rewards depend on ingratiating oneself with senior management? In 1999 and 2000, Nokia bosses topped the income tables in Finland and Ollila was number one. In a list of the top-earning Finns from 1993 to 2012, calculated by Esko Seppänen, a former Member of the European Parliament, Jorma Ollila (€83 million) was in 14th position (Seppänen 2014). The calculations were based on income known to Finnish tax authorities, but Jyri Hänninen of Helsingin Sanomat revealed in 2014 that Ollila was holding some assets in Luxembourg (Hänninen 2014). Ollila was later fined by the Finnish Financial Supervisory Authority for failing to declare these assets; the fine was $€ 3,000$. 
Share option schemes, like many other fiscal innovations in the 1990s, came to Finland from Sweden. According to one account, Georg Ehrnrooth of Lohja Corporation, later member of Nokia's board of directors, was the father of Finnish options schemes. After hearing that Sweden's Wallenberg family was distributing bonuses in Wallenberg companies so that their managers would work harder, Ehrnrooth designed an incentive scheme for Lohja executives.

It was also in the late 1980s that Yrjö Kopra and Erkki Helaniemi, then at Kansallis-Osake-Pankki commercial bank, noticed how surprised US shareholders were that there were no executive incentive systems in Finland. Kopra and Helaniemi began to work with companies like Amer (tobacco), Instrumentarium (healthcare equipment) and Aamulehti newspaper (publishing) and, in 1988, they established Alexander Corporate Finance to systematically promote share options in Finland, based on the Anglo-Saxon model. The logic is simple: the option gives the right to buy a share at a predetermined price, regardless of its market price. If the market price rises higher than the predetermined price, the option becomes valuable. Otherwise, it is worthless.

Nokia soon became a client of Alexander Corporate Finance. It wanted to be a global corporation based on the Anglo-Saxon model. Kopra and Helaniemi devised several option issues at Nokia in the 1990s. When the first was unveiled in 1994, Nokia's inner circle could already foresee the riches that lay ahead. Finnish investors were blind to Nokia's prospects and some, like KansallisOsake-Pankki commercial bank, a major Nokia shareholder, were selling Nokia at bargain-basement prices already in 1992, because they did not believe the company could halt its spiral of losses. Markku Kuisma and Pekka Seppänen (2015) have calculated that, if Kansallis-Osake-Pankki had held on to its Nokia shares until 2000 , the shares would have been worth $€ 20$ billion.

Simo Vuorilehto, CEO of Nokia until 1992, did not believe in the company either. Vuorilehti sold his Nokia shares and bought a boat. Measured by lost earnings, it was surely the most expensive sailboat in Finnish history (Nordqvist 2017: 148). 
Then a few foreign investment funds started to believe in Nokia's prospects. By the end of 1992, US funds were paying very close attention to the company and its focus on mobile phones. What made Nokia difficult to analyse was its dual-class share system and shares with more voting rights were also more attractive, but inaccessible to foreigners. The Nordic asset management company Elite Alfred Berg made large profits in Finland, and gave fabulous bonuses for its employees, by creating what it called 'cash units', financial instruments that were linked to Nokia tied shares, but could nevertheless be sold to foreigners.

Peter Seligson, then head of Elite Alfred Berg, Finland, said in his interview that the firm wrote its first positive financial analysis of Nokia in 1993. 'We didn't understand the importance of the business they were in. We studied the company only from the perspective of value', he told me in the interview. 'Nokia's market capitalisation was sometimes as low as 2 billion markkas but they had 3 billion in working capital as well as a great quantity of liquidable assets and long-term claims. It was not hard to add the figures together. Also, Nokia was doing the right things.'

This analysis was a watershed. In 1993, Nokia and many other Helsinki stock exchange companies became magical. Share prices doubled. For one thing, Finland devalued its currency twice in 1993, which greatly increased the competitiveness of exports. Moreover, the government abolished limitations on foreign ownership of Finnish shares. Hypothetically speaking, an investment of $€ 100$ in Nokia shares in 1992 would have been worth between $€ 40,000$ and $€ 60,000$ by the summer of 2000 depending on exactly when the shares were bought (calculation by Patrik Westerback, expert on share price history).

This bonanza was shared by quoted companies in need of capital, the financial market, brokers and many service companies. Suddenly, the whole Helsinki Stock Exchange was on the world map and Nokia subcontractors rapidly sought a listing. One of those who made a fortune by selling his IT-company in 1996 was 35-year-old Juha Sipilä. In 2015, Sipilä, representing the Centre Party, became Prime Minister of Finland. 
Nokia's result and the rise in its share price constantly exceeded expectations, and more share options were distributed all the time. It is difficult to find a causative link showing that the share options led to improved profits. Nevertheless, the government at the end of the 1990s, led by Paavo Lipponen, thought that state-owned companies would also produce better results if their top executives were offered big carrots, and a similar system of rewards was designed. It was a mistake that cost the public sector a pretty penny. The government soon noticed that the programme was excessive, but the financial contracts were hard to change. And anyway, greed had begun to spread.

'It was musical chairs played between friends', said the social democrat Arja Alho, who was Deputy Finance Minister from 1995 to 1997, in her interview. The board of one state company often consisted of chief executives of others. A small group were setting their own incentive schemes.

In this way, Nokia's corporate culture spread into the rest of Finnish business life, even state-owned companies, increasing the pay gap between executives and ordinary workers. The journalist Timo-Erkki Heino of the Finnish Broadcasting Company YLE calculates that, in 1995, the head of a major company received 14 times more than an ordinary wage-earner, but in 2009, he received 31 times more. This calculation excludes Nokia, where the gap was even larger. 'At the top sat Nokia's Jorma Ollila, with earnings of more than 50 million euros in 2000. This was 2,413 times the wages of an employee' (Heino 2011: 523).

If Nokia shares showered gold on Finland in the second half of the 1990s, the following decade was entirely different. By late autumn 2000, it was clear that the IT sector was heading for difficulties. The Nokia share price peaked at $€ 65$ in 2000 . By July 2012 , it had fallen to $€ 1.33$. Kim Lindström, an expert in Finnish securities, notes that if one had invested $€ 10,000$ in a basket of Finnish manufacturers like Kone Corporation at the start of 2002, the shares would have been worth nearly $€ 170,000$ in 2014 , an annual appreciation of more than 25 per cent. However, Nokia shares worth $€ 10,000$ in 2002 were worth only $€ 3,000$ in 2014 , an 
annual yield of -9 per cent. Of the 103 companies on the Helsinki Stock Exchange, only 12 fared worse.

Peter Seligson, who had foreseen Nokia's meteoric rise in 1993, left Elite Alfred Berg, Finland, in 1998 to establish Finland's first online brokerage. Plain-spoken as ever, he was from then onwards describing Nokia's share value as 'challenging. This is polite broker-speak for 'sell swiftly before the value plunges'. It made him unpopular with Nokia and with another Finnish IT comet, mobile operator Sonera, which banned him from their meetings with analysts, he says in his interview.

\section{Sitra}

The riches spread in surprising places. One organisation that became affluent through Nokia stock was the Finnish Innovation Fund Sitra. The Finnish Parliament had established the fund in Finland's 50th anniversary year, 1967, and 'Sitra' is the Finnish acronym for 'Fund for the Commemoration of Finnish Independence. The original purpose of the fund was to support projects that would boost economic growth. Initially, the fund was owned and managed by the Bank of Finland, but the Bank's managers did not want responsibility for risk-bearing investments. In 1992, Sitra became an independent foundation accountable directly to Parliament.

After separation from the central bank, Sitra needed a capital injection, but Parliament had little to give it apart from a stack of about 1.5 million Nokia shares, which, in 1992, were almost worthless. The share's bookkeeping value was about 162 million markkas, but their stock exchange value was only 70 million markkas. The government had received the shares in 1987, when it sold Nokia its share of their jointly owned company Telenokia. At the turn of the millennium, Sitra sold the Nokia shares for $€ 420$ million and invested the money in lower-risk assets.

Sitra's President Mikko Kosonen (2008-2019) says in his interview that Sitra used the yield from Nokia to finance hundreds of small enterprises, and to create tens of thousands of jobs. 
A considerable amount was invested in biotechnology companies, which proved to be a bottomless well, but 'Sitra's function is not to earn money but to stimulate the Finnish economy, to innovate, to take risks and to experiment', he says in his interview. Thanks to its sale of Nokia shares, the foundation's capital peaked in 2000-2001 at $€ 1$ billion, but then fell by half when ICT stocks collapsed. At the end of 2016, it was $€ 807$ million. 



\author{
CHAPTER 8
}

\title{
Nokialand Is Born
}

Nokia put Finland on the world map for new technology, quality products, global marketing and brilliant image building. The company turned its home country into a branded nation, Nokialand based on 'Finnishness'. Finnish design, innovation, business, management and technology shared in the success, and the country is still reaping the rewards. Nokia became associated with 'cool design, the technological avant-garde reputation of the Nordic countries, and the technological, aesthetic and marketing savvy of a small, highly advanced European country' as a flagship for 'cell phone culture' (Goggin 2006: 42).

Internationally, Finland became known as the 'mobile nation' at the forefront of development, where technology could become a natural part of life. Just as Lars Magnus Eriksson is still associated with Swedish industrialisation and Alfred Nobel with the 19th-century era of inventors, Nokia became a symbol of renewal. Newsweek declared in May 1999: 'The Future is Finnish' (Klee \& Bensko 1999); Forbes reported in the same year on the 'Wireless Wonderland' (Young 1999). Under the headline 'Just Say Nokia', the magazine of emerging technologies, Wired, told its readers that 'in the northern skunk works called Finland, the 21st century is in beta' (Silberman 1999). The Financial Times responded in a similar vein with 'Hello world, Helsinki calling' (Burt 1999). These stories of a fantastic country, forgotten since the Second World War, but now back on the map, seemed to know no bounds. In 
fact, these legends were backed by purposeful marketing and machined by Nokia.

In summer 1993, a Finnish rock group called the 'Leningrad Cowboys' gave a concert in Helsinki's Senate Square, accompanied by the 159-strong Red Army choir, formerly an official part of the Soviet armed forces. The ensemble was called the 'Total Balalaika Show' and the event became legendary worldwide. The Soviet Union had dissolved in 1991 and the Iron Curtain had fallen. It is impossible to exaggerate the symbolic value: Finland was now mentally part of a free, creative Europe, no longer cringing in the shadow at the border to one of history's most repressive countries.

Nokia grasped the value of the event and organised a similar one the following summer in Lustgarden Park, Berlin, which drew a crowd of over 60,000. The 1994 event was called the 'Nokia Balalaika Show' Germany was Nokia's biggest market area in Europe, and the Leningrad Cowboys, also a film by the renowned Finnish director Aki Kaurismäki, had achieved cult status in the country. Nokia built its brand around the event at the same time as the last Russian soldiers were leaving the newly unified Germany. Finnish companies had never previously dared to take such a risk, not least for political reasons (Brander 2019), but it paid off. The concert was a roaring success and the memory of it is still valued by those who were there.

'The exotic suited us well', recalls Nokia's then-Communications Director Lauri Kivinen in his interview. 'We went around trade fairs with the Leningrad Cowboys and our parties were definitely the most popular.' It was Kivinen and his predecessor Matti Saarinen who had proposed taking the Leningrad Cowboys to Berlin. 'It cost us five million markkas [ $€ 1.2$ million in 2018 money]. I asked Anssi Vanjoki [responsible for building the Nokia brand] and he said okay, take the money from the marketing budget if you promise to handle everything. I don't have the time.'

Nokia's world tour took the Leningrad Cowboys to cities such as Geneva, Cannes, Stockholm, Dallas and New York. The Berlin Wall had collapsed, the Soviet Union had dissolved and China's Great Wall seemed to be crumbling under people's demand for 
democracy. Globalisation expanded markets and at the same time allowed Nokia to shift production to countries with cheap labour. Nokia was a pioneer in marketing and communications in many ways. Back in the 1970s, it had been the first company in Finland to create a multimedia wall outside its head office in Helsinki Railway Square. It was the first Finnish company to register its name as a network address, www.nokia.fi. It even registered the Finnish word for mobile phone 'kännykkä' in 1987, or more accurately, it made the application in April 1987, and the Patent and Registration Office approved the application in May 1989 (Finnish Patent and Registration Office 2020). Former Prime Minister Matti Vanhanen remembers in his interview how exceptional Nokia was: 'Marketing, design, branding-Finland has never been strong in these and Nokia's example simply underlined it.'

The creation of a worldwide brand began in the 1980s, when Kari Kairamo was Chief Executive. At that time, Nokia produced consumer goods like tyres, Wellington boots and tissue paper. Tapani Yli-Saunamäki, who was working in Nokia's communications department in the 1980s, says in his interview that Kairamo demanded a new profile for the company. 'In his blunt way Kairamo said that we make products called mobile telephones but no one in the world is going to buy them from the world's largest maker of toilet paper'

One of the first moves was an outdoor advertising campaign in Sweden. It was so successful that the Swedish Employers Association SAF referred to the 'threat from the east' (i.e. Finland) in a countercampaign. 'We had a listing on the Stockholm Stock Exchange, we wanted better workers, we wanted attention in the media and contacts with analysts, stockbrokers and so on. We decided on a really large promotion', Yli-Saunamäki recalls in the interview.

In May 1987, Nokia bought all available outside advertising space in Sweden and most of what was available in Norway. With white text on a blue background, the advertisements began with a statement about Nokia and then a question. 'Last year our share price rose 109 per cent. What company?' Or 'Our equipment is at the head of the line in the wine and spirits shop. Who are we?' 
(The shops used Nokia cash machines.) A week later, the text was changed overnight and replaced with a logo and a single word: 'Nokia.' 'The effect was amazing. There was blue everywhere, in the streets of Stockholm and the squares of Sweden. The media wrote reams about it ... and the costs were reasonable', says former Communications Director Matti Saarinen in his interview.

During the 1980s and 1990s, Nokia expanded its marketing and branding efforts: the company became the main sponsor of the Stockholm Open tennis tournament. Nokia's visitors were now side-by-side with the Swedish elite. Sponsorship of tournaments continued in Germany with the Nokia Grand Prix. Then Nokia moved on to ski jumping, taking its guests to places like GarmischPartenkirchen, Oberstdorf, Engelberg and Predazzo. Ski jumping has for decades held a special place in the hearts of sports-minded Finns. This was the fantastic era of Finnish ski jumper Matti Nykänen (1963-2019) who competed from 1981 to 1991 and is widely considered to be the greatest male ski jumper of all time. In India, Nokia sponsored cricket; in the United States it sponsored American football and its championship game, the Super Bowl.

The company also expanded into Formula One car racing, another favourite sport among Finns, becoming a sponsor of the Tyrrell Racing Organisation. Tyrrell had been successful in the early 1970s, when it won three Drivers' Championships and one Constructors' Championship with legendary Jackie Stewart in the driver's seat. Now it was past its best days, but that meant sponsorship was cheaper. Nokia even had talks with Ferrari and then BMW-Williams, but they came to nothing. 'The Ferrari cars were red and carried Marlborough and Shell advertisements', says Tapani Yli-Saunamäki in his interview. 'If we had added the blue Nokia logo, it would have looked odd, like a subtenant. We weren't seeking that kind of image.'

Back in 1991, Jorma Ollila had told Anssi Vanjoki to create a brand from Nokia mobile phones. The handsets were until then sold under many names, including Mobira and RadioShack, and they also carried the logos of their operators. In bringing them all together under the Nokia name, and turning that name into a worldwide brand, Vanjoki was successful beyond expectations. 
Alongside Yahoo, America Online and Google, Nokia is indeed one of the few trademarks born in the 1990s that still survives.

Part of any marketing campaign is to get the product into famous hands. In 1997, Val Kilmer, playing 'The Saint', used a Nokia Communicator to foil his enemies. In 'The Matrix' (1999), Keanu Reeves used a curved Nokia 8110. Batman in 'The Dark Knight' had a Nokia 5800 for surveillance in 2008. But the most classic piece of product placement dates from 1989, when Nokia director Stefan Widomski put a Cityman phone in the hands of a curious Mikhail Gorbachev, the last president of the Soviet Union, who was visiting Finland that year. The president's security men had previously taken the phone apart to ensure that it did not contain a bomb. Weighing 800 grams and costing €6,500 in 2018 money, the Cityman soon became known as 'the Gorba' in Finland.

Nokia relied heavily on relationships and sponsorships. Building the Nokia brand in the 1990s cost about €1 billion, including advertisements on Music Television and the TV news channel CNN. With hindsight, it was cheap at the price. By 2000, Nokia was already one of the world's five most valuable brands (McDonough \& Egolf 2015: 1148).

Part of the image was the 'Nokia Tune', discovered by Anssi Vanjoki at the start of the 1990s. It comes from a recording of 'Gran Vals' by the Spanish guitarist and composer Francisco Tárregan (1852-1909), and became the ring tone of billions of mobile phones around the world. In 2011, Nokia organised a competition to update it. Nearly 3,000 people from 70 countries took part. A ponderous dubstep version won the competition.

In 2013, selling the mobile phone business, Nokia left consumer markets and does not need advertising to promote its brand. The name on the side of mobile network equipment makes no difference to the general public.

\section{Connecting People}

In 2009, the Nokia brand was worth US\$35 billion according to the global brand consultancy Interbrand. A brand has various components: consumer experience, reputation and quality. Many 
think that a brand is the product of marketing, but in reality, it is the essence of the whole organisation, its spirit, function and goals. A brand is not information, but context. Nokia's context is the well-known marketing phrase 'Connecting People', later copied by, for instance, Facebook, as well as the Nokia blue colour.

Every company believes it knows why it exists; its management tries to express this as simply and efficiently as possible. Part of this communication consists of memorable taglines. Sports equipment manufacturer Nike has crystallised its appeal with 'Just do it', Apple with 'Think differently' and McDonald's with 'I'm lovin' it'. Among Finnish companies, a successful example is 'Lifting businesses', the tagline of the engineering company Konecranes. Elevator manufacturer Kone goes with the more puzzling 'Dedicated to people flow'.

Ericsson of Sweden shows the damage that can be done to a company's image and cohesion by constantly changing its slogan. In the middle of the 1990s, the company used the phrase 'It's all about communication, the rest is technology'. This was later changed to 'Make yourself heard'. By then, Nokia and Motorola were deposing Ericsson as the world's largest mobile phone manufacturer, and the Swedish satirical magazine Blandaren twisted it into 'Ericsson: Make yourself third' (Karlberg 2005). In 2001, Ericsson disposed of its mobile phones division and its tagline became 'Taking you forward'. Ever since, new slogans, mottos and taglines have come thick and fast; 'Powered by Ericsson'; then 'Power of mobility'; then 'Mobile Internet Revolution, it's an everyday thing'; then 'Thinking ahead'. The last time I checked, in 2020, it was 'Quest for easy'. The company has spent billions on forging its identity and culture, but it seems obvious that Ericsson is still trying to figure out how to define itself.

Nokia management decided to do things differently, investing its marketing budget wisely to create one of the world's bestknown and most highly valued brands. Nokia Chief Marketing Officer Tuula Rytilä (2012-2014) noted in a blogpost that: “Connecting People" is more than a tagline. It's a mission statement that has guided almost everything we've done for over 20 years' (Rytilä 2013). 
During the crazy years of Nokia in 2008 and 2009, the tagline gained an ironic or dystopic tone. When employees were working long hours, they only half-jokingly rebranded Nokia in private as 'Disconnecting families'. There was less to laugh about when the text 'Disconnecting people' was carried on the placards by German demonstrators protesting against the closure of the Nokia plant in Bochum in 2008. And, when Nokia was trying to change privacy laws in Finland in 2008 to 2009, one jester came up with 'Lex Nokia: Controlling People' (see http://www.seppo.net/lex-nokia -lyttaa-perustuslain).

While Stephen Elop was the Nokia CEO, he and his Head of Marketing Jerri DeVard planned to change the tagline, but their careers at Nokia were too short. During Rajeev Suri's term, Connecting People was not actively used, but the reason may be that the company, now producing network equipment, no longer connects people directly, but mediates data in computer networks.

'Nokia Connecting People' was also the name that the company gave to its share option schemes for employees. The name lasted until 2007, when most option holders were gaining no benefit from them because, although the company was still making large profits, the share price was falling. Connecting People is one of the world's most effective and recognised taglines, but there are many versions for how it was created.

In his memoirs, Jorma Ollila (2013) says that he asked Communications Director Matti Saarinen to invent a tagline for the company in autumn 1992. Saarinen sat down with his colleagues Lauri Kivinen, Yrjänä Ahto and Martin Sandelin and they came up with the words. The one remaining problem was to get them accepted, so Saarinen says in his interview that he drew up a list of 20 possibilities where the other 19 were deliberately contrived. Unfortunately, when the executive team went over the list, one of the managers, Paavo Rantanen, said Germany would never accept an English-language tagline.

'We were in a hurry so I asked if I could send them the German version later in the day', said Saarinen in his interview. 'For the hell of it, I sent the translation in the form "Die Gute Verbindung von Mensch zu Mensch (The Good Connection from Human 
to Human)". After that, no one spoke about a German tagline. Anyway, the Germans loved Connecting People.'

This is the official version, but who first thought of the words? In his interview, Saarinen says he does not remember, although he does recall that six different Swedish advertising agencies had claimed the honour. Several other sources name a certain Ove Strandberg, who was working part-time for Nokia in 1992, while he completed his engineering degree at Helsinki University of Technology. I tracked Strandberg down in 2015 for an interview.

At the end of the 1980s and early 1990s, Nokia was operating under several different names (for instance, Mobira, Tandy and Technophone for mobile phones, Mikromikko for computers and Salora for consumer electronics), but wanted to create a unifying element between the units. 'Employees were asked to suggest names for internal Nokia events, seminars and briefings. They wanted a common denominator', Strandberg told me in his interview. He had two ideas. 'One was Nokia Connecting People [but] I wasn't thinking for a phrase to be used outside the company ... but for something to be used in house, so I thought my second idea, Connecting Nokia People was better. I gave my suggestion to a colleague ... and he passed it on.'

In the summer of 2003, Strandberg was contacted by Helsingin Sanomat to find out if he was indeed the author of one of the world's top taglines. He turned to Nokia's communications department to ask what he should say. 'They replied with the official version that the phrase had been invented in teamwork within Nokia.' Later in the year, though, he was informed by Nokia's communications manager Lauri Kivinen he could tell friends he was part of the team.

Several other people, such as the Swedish advertising veteran Thomas Gad (Sandén 2008), have in recent years claimed they were behind Connecting People; however, the story of a young student reveals clearly how Nokia worked as a collective where it was difficult to tell exactly who was behind an innovation. There are hundreds of people who have made major contributions to the success of the company without ever getting-or even wantingpublic recognition. 
The strength of Connecting People is underlined by the fact that it was also used by Facebook up until 2017, when Mark Zuckerberg decided that connections are not enough, there needs to be communities (Chaykowski 2017). As a side note, Facebook is still using the official brand colour 'Nokia Blue'. 



\section{CHAPTER 9}

\section{Subcontractors in Crisis}

Nokia's success would have been impossible without the close collaboration of hundreds of Finnish and foreign subcontractors. The subcontractors were ready to die for their client; however, many realised too late that Nokia was ready to sacrifice them on the global battlefield if need be. Following Brandenburger and Nalebuff in their influential book Co-opetition (2002), building on game theory, business can be conceptualised as simultaneously war and peace, competition and coordination of the kind presented in the section on Nordic cooperation. Brandenburger and Nalebuff are blunt: 'The goal is to do well for yourself. Sometimes that comes at the expense of others, sometimes not' (2002: 4). Initially, Nokia treated the subcontractors, these aides-de-camp, well, but, as Nokia made new alliances, they became a burden later abandoned by the company.

This chapter deals with a group of Finnish companies that were Nokia's most important stakeholders for many years as they formed together the industrial cluster behind the global success of Nokia. With the emergence of common mobile communication standards (NMT and GSM), Nokia could focus on parts of the product in which they had specialised skills, purchasing all other components externally from subcontractors (Sadowski, Dittrich \& Duysters 2003); thus, innovation networks or clusters of companies evolved. Nokia's years of rapid growth in the 1990s led to the globalisation of its predominantly Finnish electronics 
subcontracting industry. These were small and medium-sized enterprises (SMEs), which in the early 2000s had already started to run out of capacity to invest in plants, machinery, assembly capacity, competence and knowledge. Nokia faced long-term problems for its local embeddedness in Finland (Sadowski, Dittrich \& Duysters 2003; Seppälä 2010) and therefore increasingly needed to develop its sourcing capabilities internationally (Seppälä 2010).

There were many victims in the subsequent subcontracting crisis. Finnish factories were discarded in Hollola, Joensuu, Kemijärvi, Kontiolahti, Lahti, Nurmijärvi, Oulu and Ylöjärvi. Abroad, the list encompasses Pécs and Komárom in Hungary, Tallinn in Estonia, St Petersburg in Russia, Monterrey in Mexico, Dongguan in China and Chennai (formerly Madras) and Bangalore (officially Bengaluru) in India.

At the beginning of 2000, Nokia and its hundreds of Finnish subcontractors accounted for nearly a quarter of Finland's exports (23 per cent in 2000). In 2008, their combined exports were worth $€ 15$ billion, about a fifth of Finland's total exports. In 2012, they had fallen to $€ 7.3$ billion, and in 2014 were only $€ 3.5$ billion. Hightechnology products as a share of Finnish exports collapsed to just over 6 per cent in 2013, a clear sign of Nokia's past importance to its home country.

The great subcontracting transformation imposed a heavy price, and many thousands of jobs were lost. Anna-Liisa Palmu, a corporate lawyer with Nokia from 1988 to 2005, says in her interview that

global business is like warfare. There are conquests to be made and soldiers in position. Some will have to be sacrificed if the front line is to move forward. The fighting is undeniably sophisticated but one must always be vigilant and never imagine that a stronghold is impregnable, because there are infiltrators on every side.

When mobile phones made their breakthrough in the 1990s, Nokia began to shift production closer to its main market areas. As new regions like Eastern Europe, China and India opened up, the economy became globalised, creating tougher competition. 
At the same time, companies in the IT sector became able to turn to countries with low wages and costs. Outsourcing began with the mass production of cheaper handsets and then advanced to subcontractors who were able to offer Nokia better quality and innovations.

Nokia's global sales of mobile phones almost doubled in just five years, from around 130 million devices in 2000, to more than 250 million in 2005; and almost doubled again in just another three years. Between the peak years of 2007 and 2011, Nokia was selling 417 to 468 million handsets annually. Each contained 200 to 300 parts, ranging from semiconductors to microphones, loudspeakers, screens and plastic shells, so every year it had to buy, inspect and assemble 80 to 140 billion components. Completed products were sent to distribution centres in 170 countries. Nokia was the only handset manufacturer with a distribution chain and customer-specific products spanning China, India, Latin America, Russia and Africa.

Over the years, design and customisation became Nokia's main competitive advantages, but the great secret behind its success was supreme control of material flows, production and distribution. As an electronics manufacturer, Nokia was exceptional in that it made most of its products at its own plants. Contract manufacturers were used only during spikes in demand. Jyrki Ali-Yrkkö of Etla economic research institute calculates that, in the peak year of 2008 , only 17 per cent of mobile phone production and 20 per cent of network manufacturing were outsourced. Its processes were the most streamlined and efficient in the industry.

The factories spat out telephones at an accelerating pace, as many as 15 a second or half a billion a year. As consumer demand kept rising, it exceeded Nokia's own capacity. Contract manufacturers provided flexibility and, by being able to meet explosive demand, flexibility meant more orders. There was also a question of costs. By turning to contract manufacturers, Nokia avoided investing in its own overcapacity. It had to commit less of its own capital in order to respond to swings in demand.

It was assumed that contract manufacturers and subcontractors would follow their client out into the world and build factories in 
places like China, the United States, Hungary, India, Brazil and Mexico. Nokia had long-term relations with contract manufacturers and subcontractors, based on trust, personal chemistry and mutual understanding. Organising complex chains of hundreds of players was like conducting a symphony orchestra.

Nokia's partners were able to ride the wave of its success for more than a decade and to make large profits, but some overinvested and disappeared. Some hung on tenaciously and others said 'thanks, but no thanks' when the stakes grew too high. During the 1990s, subcontractors became a de facto part of Nokia, although they had separate shareholders and lived separate lives.

'It was truly a rewarding time for everyone. Elcoteq, Perlos, Kyrel and Eimo made so much money that they did not really know where to put it all. The companies were unwilling to admit it but their independence was shrinking all the time', said interviewee Andreas 'Anton' Tallberg, then-Chairman of the board of Perlos. This company had been one of the most important subcontractors for Nokia, focused on cost-efficient mass-production of plastic parts for mobile phones.

Nokia's attitude changed when the company became more successful. At the turn of the millennium, Nokia's management clearly stated who was in charge and began to issue commands to subcontractors, micromanaging their work. It was difficult for them to flout these directives. Tallberg continued: 'Nokia was like a loaded pistol on a silver plate.' This refers to the fact that subcontractors were offered fantastic potential for expansion, but the risks were also enormous.

By 1999-2000, Nokia's management has become pathologically afraid that competitors were copying and acquiring its skills via its subcontractors. According to people interviewed for this book, the company built ever-higher walls between its processes and its subcontractors, and turned its gaze inward. A free flow of ideas and experiences had created excellent results, but this had now been transformed into a policy diktat that instead of collaboration was based on issuing decrees and directives. According to my interviews for this book, subcontractors noticed that it was 
becoming increasingly difficult to find other customers, probably because of Nokia's dominance in the field.

According to Sabel and Saxenian, Nokia required its suppliers to adapt their business models to its requirements, 'forcing them to focus on cost reduction, decrease delivery time, and improve efficiency, and flexibility, rather than developing independent market positions' (2008: 78).

Nokia took over materials management and handset production in the mid-1990s. This was precipitated by a profitability crisis in the winter of 1995-1996, when Nokia lost control of inventory management, material flows and subcontractors at a time of fast growth. There were many reasons for the crisis: excessive costs, logistical problems, a shortage of components and poor product quality. In December 1995, Jorma Ollila had to issue the first profit warning in his career at Nokia, a humbling experience (Ollila \& Saukkomaa 2016). After the warning, Nokia management put its IT and reporting systems in order with the help of the German software company SAP, so as to have a better picture of events (Doz \& Wilson 2017). From this point onwards, production logistics depended on demand instead of supply; in other words, the company manufactured only what had already been ordered.

In his history of Nokia, Martti Häikiö gives credit for this solution to the CEO of Mobile Telephones, Pekka Ala-Pietilä, Production Director Frank McGovern and Logistics Director Pertti Korhonen, but overlooks the role of Eero Eloranta, a professor at Helsinki University of Technology. While working at the university, Eloranta also served as logistics consultant for Nokia to several years, an example of cooperation between Nokia and universities at its finest. In addition, the US consultancy firm McKinsey played a role in reshaping Nokia.

Nokia now had the logistical basis for ever-faster growth. Production volumes doubled and dozens of new models were launched each year. At the start of the 2000s, however, management realised that the current capacity, competitiveness and innovativeness of subcontractors were inadequate. The subcontractors also lacked 
capital, so investments became a burden for them, despite joint efforts to solve the problem. Nokia decided to safeguard its future with Chinese subcontractors.

'Finnish subcontractors didn't have the answer to our problems. They did not have the processes, capacity, capital or mindsets to keep up with developments', said former Nokia executive Robert Andersson in his interview. Some representatives of former subcontractors present an opposite view in their interviews: the cooperation was world class and competitive.

In 1998, Nokia modernised its procurement organisation. Pertti Korhonen, the executive responsible, felt that the subcontractor field was too fragmented and complex to be managed efficiently. The new watchwords became timely logistics and partnering.

One important figure suspiciously missing from Ollila's memoirs is Swiss Jean-François Baril, the man who shaped Finland's entire industrial structure. Baril as an individual connects the demise of Finnish subcontractors to the rise of Chinese manufacturers. He continues to play an important role in Nokia as the founder of HMD Global in November 2016, a company that has the licence to manufacture and sell Nokia phones. Baril had previously worked in procurement at Hewlett-Packard and Compaq, and caught Pertti Korhonen's eye because computer manufacturing had the most efficient material flows in the field of electronics, equal to that of automobile manufacturing. Baril promised to reorganise Nokia's supply chain, eliminating the capacity problems and bottlenecks that prevented growth. He began as Chief Purchasing Officer at Nokia Corporation in January 1999. There, he laid the foundations for its success and, equally, the catastrophe that befell Finland when the whole ecosystem of subcontractors and industrial manufacturing became extinct.

In autumn 2003, Nokia announced its new 'cluster strategy', in which a few vertically integrated subcontractors or subcontracting consortiums would manage materials and be established close to Nokia's production locations (Seppälä 2010). The implementation of the cluster strategy was managed by Nokia's sourcing organisation led by Jean-François Baril. Manufacturing in Europe was 
becoming expensive so Nokia intended to look to China and other low-cost countries. These were also the places where mobile phone markets were growing the fastest.

There were several reasons why some Finnish subcontractors could not match global competitors. One was the enormous demand for mobile phones that had developed in Asia. Handsets had also been standardised more rapidly than anyone expected, so even technically complex phones could be manufactured cheaply in large volumes. However, Nokia executives were still unsure that new partners in China would be able to meet their commitments, so they explained their supply strategy openly in conferences and meetings with existing subcontractors.

A decisive factor was the emergence of a new player in the manufacturing game. In 2001, the Taiwanese electronics manufacturer Hon Hai Precision Industry Co., Ltd, known asFoxconn Technology Group, had announced the launch of its mobile phone components business. The firm had entered mainland China in 1998 with 150 staff based in Shenzhen. By 2001, Baril had already introduced Foxconn and its founder and CEO Terry Gou to Nokia’s management. A year later, Foxconn was rewarded its first Nokia component delivery agreement. The next two chapters will examine this development in more detail.

Subcontractor margins had gradually begun to shrink, although production volumes had increased. The halcyon days of subcontractors were over. At the start of 2003, Jalo Paananen, owner of plastics manufacturer Eimo, sent an urgent letter to Chief Purchasing Officer Jean-François Baril and the head of Nokia Mobile Phones, Matti Alahuhta. According to sources interviewed for this book, he pointed to their shared history and how Eimo had helped Nokia’s success by developing an impressive amount of new technology. Paananen said the future seemed uncertain in the light of current changes in the procurement processes. $\mathrm{He}$ asked if he was right to worry.

Eimo had long been struggling with problems of its own making. It had acquired plants in Pécs, Hungary and a US company, Triple S, but had failed to integrate these into its own 
operations. It had also wanted to create a globally competitive cluster with two other Nokia subcontractors, Elcoteq and Perlos, but had been told by Jorma Ollila that Nokia disliked the idea. Nokia seemed to fear that the proposed cluster of subcontractors would be too strong.

This is a delicate part of Finnish industrial history, uncomfortable for the victors and the vanquished alike. Timo Seppälä, a researcher at Etla, calls Nokia's tactics 'seduce and squeeze' (Seppälä 2010; Seppälä 2013). Seppälä formerly worked at electronics contract manufacturer Elcoteq, and saw at close quarters how Nokia demanded price cuts of 10 to 20 per cent annually between 2000 and 2007.

The seduction occurs when the customer seduces suppliers into investing in additional capacity or additional technologies, and the squeeze occurs after suppliers have expanded their capacity and learned new technologies, when the customer then tightens his belt in a bid for lower prices and more flexible terms of their agreement in practice. (Seppälä 2010: 15)

Other Finnish subcontractors had their own collaborative plans. Circuit manufacturer Aspocomp and Elcoteq established Imbera Electronics in 2002, for joint research and product development in new fields. In the same year, Aspocomp and Perlos set up Asperation. But, time and time again, closer cooperation failed according to several people interviewed because key people in familyowned companies could not agree on the conditions for working together. Some cared only for the value of their own businesses and did not want to share control with others.

In response to the concerns of Eimo's Jalo Paananen, Jean-François Baril of Nokia helped to arrange a meeting between Paananen and Terry Gou, owner of the Taiwanese contract manufacturer Foxconn. The final agreement was drafted with the help of Eimo's financier, Handelsbanken, and the agreement was signed in a sauna cottage near Lahti, Finland. Foxconn acquired Eimo in 2003. The Paananen family got a good price for their shares and Foxconn deepened its relationship with Nokia. Eimo's factories 
in Lahti, Hollola and Laitila, employing 1,400 people, were now owned by Foxconn. However, to the horror of employees, within a couple of years, production was transferred to Foxconn plants in Hungary and China (Mikkonen 2006).

It was a similar tale at Perlos, a major supplier of technical plastic parts. The Sohlberg family owners made large profits from Nokia orders in the 1990s, when their factories in Joensuu, Eastern Finland, were working above capacity. In 1996, a Swedish private equity firm EQT acquired Perlos and obtained a stock exchange listing, as did other Nokia subcontractors in 1999. EQT sold its shares as soon as possible and advised the Sohlberg family to do the same, but instead they increased their holdings. Perlos made several attempts to expand operations, including the purchase of Swedish antenna manufacturer Moteco in 2001, but the projects failed (Seppälä 2010).

By 2007, Perlos was in deep crisis and the new Chief Executive, Andreas Tallberg, according to his interview began seeking a buyer for the business. This time, the highest bid was not made by Foxconn but by another Taiwanese company, Lite-On, which wanted to get into Nokia subcontracting. When Lite-On came into the picture, Elcoteq finally gave up its idea of creating a Finnish cluster to supply Nokia.

The Perlos story was coming to an end, and its factories in Kontiolahti and Joensuu were closed. Despite its disappearance, however, the company's progress from a maker of plastic bottle caps to producing Nokia technical plastic parts created competence that is still in demand around the world. 'It is fair to say that Joensuu's skills in injection moulding and making components are entirely due to the partnership between Nokia and Perlos', Andreas Tallberg explained in his interview.

For many years, Perlos had tried to become a subcontractor for more companies than just Nokia, particularly for Motorola, but without success. The US company may have feared that Perlos was too close to Nokia, which was becoming steadily more integrated with its subcontractors. Subcontracting for Nokia could even seem like a curse, because Nokia jealously guarded its 
interests and made sure that no competitor could copy its processes or products.

Once Lite-On had acquired Perlos, the curse was lifted. Andreas Tallberg, who joined the board of Lite-On, says in his interview that efforts began immediately to find new customers 'and they were successful. Obviously nothing happened overnight but Lite-On was soon involved with major companies such as Apple'.

Another company that collapsed was Salcomp, a producer of mobile phone antennae. Its headquarters were in Salo and it had a factory, employing 280 people, in Kemijärvi, Lapland. It moved to China in 2003. To be fair, the factory was making heavy losses and would not have survived very long without government support. In his interview, Erkki Virtanen, the top civil servant at the Ministry of Labour and Employment until 2008, described Salcomp as a cynical exploiter of state aid. Veli-Pekka Saarnivaara, former head of Tekes, says in his interview that support to Salcomp should have been for $\mathrm{R} \& \mathrm{D}$ rather than expansion. 'The state should create skills, which usually remain even if the employer disappears.'

EQT, the Swedish private equity firm that had briefly owned Perlos, acquired Salcomp in 1999. After Salcomp's production was moved to China and costs were sharply cut, it became an excellent investment. Its factories in China, Brazil and India are still in operation today, and in 2020 it was the world's market leader in smartphone and tablet chargers. The company's head office is still in Salo, but almost all of its employees are abroad. In June 2019, the company was sold to Chinese manufacturer Lingyi iTech.

Andreas Tallberg says in his interview that, with Salcomp, EQT saw the shape of the future at an early stage. The price pressure was enormous. Competition from Asian component manufacturers was getting steadily tougher and the life cycle of products evershorter. Whereas Perlos ignored economic analyses and decided to go heavily into debt by following Nokia 'like a good Boy Scout', EQT at Salcomp took a different route.

Hansaprint was a subcontractor which produced printing work for Nokia: Nokia's first television manuals and, in 1994, handset instructions. Hansaprint had 10 to 20 of its own subcontractors 
and a low-cost plant in Hungary. By autumn 2008, Hansaprint was negotiating building a printing plant in Romania and becoming Nokia's only print provider. In less than a year, however, it was doing absolutely no work for Nokia. In winter 2009, Nokia had demanded that Hansaprint reduce its prices by 30 to 40 per cent as a condition for continuing cooperation. 'It's conventional to say we parted as friends but ... that's not entirely true', said Hansaprint's then-Chief Executive Timo Ketonen in his interview. 'They had us in a stranglehold ... it was getting difficult to breathe.'

The various experiences of Nokia subcontractors, including Laukamo and Protopaja, ${ }^{8}$ which had survived despite Chinese competition, indicate that different strategies towards Nokia yielded different results. Their decision to not jump on Nokia's bandwagon on the road to globalisation was key to survival. They also show that industries have to constantly renew themselves in order to retain their vitality (Jennings 2012). Instead of disappearing, a company can change shape and rise again. These examples illustrate Joseph Schumpeter's (1950) concept of creative destruction, the circle of innovation.

Each company answered in its own way to Nokia's expectations and the demands of the market. Nokia steadily became an increasingly difficult customer, a global giant that was losing its way. Subcontractors felt that Nokia was no longer operating as fast and efficiently as before, even though the life cycle of products was getting shorter.

The subcontractors had teams that were united and had been working with the projects in question for a long time, but Nokia kept rotating its engineers and managers. 'It was devastating. We had to keep going back to page one when a new guy arrived,' Andreas Tallberg reveals in his interview.

Nokia's version of the story is completely different. A former executive says in his interview that he is still shocked by the attitude of subcontractors.

They believed that X per cent of Nokia orders -50 or 60 or 70 per cent-automatically belonged to them because they were Finn- 
ish and could offer certain advantages. It does not work like that. They had quality problems. At the end of the 1990s and start of the 2000s, they were far from the best in their fields.

This could be interpreted as defence of actions taken, as researchers have pointed out that collaboration was a key component of Nokia's success (Ali-Yrkkö 2001a; Seppälä 2010).

Nokia's global expansion helped a number of foreign companies create a strong position in the world market. These included electronics manufacturers like Foxconn and BYD, as well as microcircuit producers like ARM, STM Electronics and Texas Instruments. Unfortunately, there are no Finnish companies in this group, which shows how difficult it was to grow in Finland in the shadow of Nokia. The favourable effects of Finland's ICT revolution disappeared when Nokia threw its domestic partners overboard. In contrast, German global giants still work closely with successful local SMEs.

After its growing pains in the 1990s, Nokia streamlined itself into a logistics miracle. Its phones were sold in every corner of the world. Its success can be attributed to supply chain optimisation, production and logistics, but they also contained the seeds of its failure. It began to build new products from common components used in previous models.

Søren Jenry Petersen, a long-time manager at Nokia, explains in his interview:

Nokia as a corporation was built out of hardware knowledge. We spent 20 years learning how to make batteries and antennas and power modules and integrated chipsets and displays and buttons and plastics, smaller and smaller and smaller. That was the fight for a better part of 15, 20 years. It was how to make them smaller, how to save components, how to remove extra components, how to integrate things and getting the products slimmer and slimmer.

Around 2007, a new world had arrived. Chipset companies like Qualcomm and others started to have all functions integrated in one chipset. 'That turned the whole paradigm of core competence 
and competitive advantage from a hardware world into a software world', Petersen continues.

In the end, industrial thinking killed innovation and creativity needed in the shift from hardware to software, telecom to internet and from telecom operator needs to end-user needs. The result was standard handsets that resembled one another. Nokia's product development was paralysed as smaller agile subcontractors could no longer feed units with ideas for new products and solutions. The smooth efficiency of its new supply chains blinded Nokia to the reality that consumers were soon going to get something very different. 



\section{The Fall of Elcoteq}

Elcoteq was by far the largest and most important one of all of Nokia's subcontractors in Finland. For many years, the destiny of this contract manufacturer was closely entwined with Nokia's. Elcoteq supplied parts for Nokia handsets and assembled complete phones at factories that it established close to Nokia's own production facilities. As Nokia's sales took off, new Elcoteq factories went up at the same furious pace. Yet, by autumn 2011, Elcoteq asked to be declared bankrupt. This was one of the most dramatic and unusual chapters in both Finnish and European economic history.

I first met Elcoteq founder and Chairman Antti Piippo in 1994, in Lohja. This was the town where Elcoteq began life as the microelectronics unit of a major industrial concern, Lohja Corporation. Piippo and his colleagues Henry Sjöman and Jorma Vanhanen had acquired the unit, employing just over 100 people, in a management buyout in 1991. They were on the crest of a megatrend. Contract production companies had sprung up in the electronics industry in the 1970s, when pioneers like SCI (the acronym which once stood for Space Craft, Incorporated) in the United States began to design, test, manufacture and distribute electronic products on behalf of other companies. Elcoteq was headed for the same market. After it became independent of Lohja Corporation in 1991, one of its first clients was Nokia, which had just begun to outsource production. 
For me, a business journalist, Antti Piippo eagerly introduced me to his business philosophy, co-evolution, and explained how companies can grow and thrive together. His business philosophy was formulated years before the above-mentioned book entitled Co-opetition (Brandenburger \& Nalebuff 2002) validated his thought on the power of collaboration.

Piippo recalls in his interviews:

Nokia supplied the materials and components needed for its products and we assembled them. At first Nokia did not trust others to monitor production quality, and it tested every subcontracted product on its own premises ... but this was slow and expensive. Elcoteq constructed its own quality control systems together with customers like Ericsson, Motorola, Saab, Hasselblad and Husqvarna. Then we offered these skills to Nokia. We had a partnership of close trust with Nokia at all interacting levels of our organisations.

In the growing sector of contract manufacturing, competition was increasing and soon weaker companies began to be eliminated. At the start of the 1990s, there were more than a thousand contract manufacturers of electronics around the world. By the end of the decade, there were only a handful left, and Elcoteq was the largest in Europe. Electronics subcontractors have continued to disappear since then, mostly through mergers and acquisitions. In 2020, there are only a few large, worldwide contract manufacturers left, of which Foxconn of Taiwan is by far the largest. As recently as 2005, Elcoteq's turnover was about the same as Foxconn's, but then the Taiwanese company raced ahead-with the assistance of Nokia's top management.

At its peak, Elcoteq had more than 24,000 employees, annual turnover of $€ 4$ billion and factories in 15 countries, including Estonia, Hungary, China, India, Brazil, Russia and Mexico. Its founder, Antti Piippo, had a remarkable vehicle for networking with other businessmen, a motorcycle club called the 'Cigar Angels'. Its membership consisted of about 40 business leaders from Finland, Sweden, Germany and France, and included Nokia executives Juha Putkiranta and Anssi Vanjoki. All the members were men. 
When Nokia announced in 2003 that its subcontracting was to be reorganised into clusters, Elcoteq expected to be the coordinator of one cluster. Another cluster would form around Foxcomm and a third around the US contract manufacturer Jabil. This new kind of partnership between Nokia and Elcoteq began well, although not all the subcontractors could see the advantages of the new strategy. No attempt was made to harmonise the revenue models of different companies within each cluster.

Another point of contention was the vertical integration of production, which Henry Ford had made into the standard method for automobile manufacturing. It meant that companies handling different stages of production-the subcontractors and the distribution chain-were to be integrated with Nokia's processes (Seppälä 2010). Elcoteq's executives felt that this type of vertical integration was better suited to products that were changing slowly, not to mobile phones. Many years later, history shows that they were right. As long as Nokia used the experiences from the PC industry and pursued a strategy of horizontal integration, with different companies providing value, things were going well. But as Yves Doz and Keeley Wilson (2017: 82-83) note, Nokia was soon becoming 'more equal than others', claiming that the interests of others were less important.

This was also the view of Tom Standage of The Economist. His book The future of technology (2005) noted that Nokia, just like automobile manufacturer Volkswagen, was excessively concerned with manufacturing 'platforms', where all handsets were constructed from the same components. This led to a bland line of phones that all resembled one another. He thought it was more likely that the handset business would shift from vertical integration to a series of horizontal layers-chips, software, manufacturing, design and branding — and that a company might be active in more than one layer.

In practice, after the adoption of the cluster strategy, Foxconn became Nokia's only contractor for its mobile phone manufacturing services. Elcoteq's management did not know, or did not admit that they knew, that Nokia was retaining its Finnish subcontractors for a transitional period only, in case something went wrong 
with its intended subcontractors in China. Nokia wanted Chinese competition for Foxconn in order to push prices down, and so it forced Elcoteq to include BYD of China (the name is an acronym of Build Your Dreams) in its cluster. Elcoteq was very unhappy about this. In his interview, Timo Seppälä, in charge of the Nokia account at Elcoteq until summer 2007, quotes Elcoteq's Managing Director in 2004: 'It is not our job to train BYD'

With Nokia buying more and more from Chinese manufacturers, Seppälä wanted Elcoteq to invest more to stay in the game. Hitherto, Nokia had helped Elcoteq to finance investments in new capacity. It had also carried most of the risk that Elcoteq's capacity would be underutilised, by paying a higher price for products when demand was low. Now, Seppälä discovered that Nokia was ordering less than had been agreed, but was not compensating Elcoteq for the shortfall.

In 2006 and 2007, talks continued between Nokia and Elcoteq at executive and board levels. Elcoteq's other large customer, RIM (Research in Motion) of Canada, called in a panic after hearing the rumour that Nokia was deserting its subcontractors according to Antti Piippo. Elcoteq was RIM's only contract manufacturer, responsible for producing Blackberries at factories in Mexico and Hungary, so Elcoteq's financial success was vital for RIM. Elcoteq's executives deny ever being told by Nokia that their collaboration would soon end, and that capacity reservations would be shifted to Foxconn. They say, on the contrary, that Nokia gave them every reason to believe that orders would continue and told Elcoteq to invest in extra capacity. In this narrative, Nokia deceived Elcoteq into acting as a standby supplier, while shifting an ever-increasing number of orders to Foxconn.

In the view of Robert Andersson (Member of Group Executive Board of Nokia 2005-2009), however, Elcoteq was in denial, unable to grasp the new competitive situation where Nokia had become a global player: 'They put too much faith in the old boys' network and promises that things would work out. Nokia did not operate like that', he says in his interview.

Nevertheless, Elcoteq was leaning on existing binding contracts with Nokia that stipulated the responsibilities of the partners and 
later received compensation for the breach against them. Elcoteq had long been aware of the danger of dependency on one large customer. At the start of the 2000s, Nokia was one of many customers, accounting for just 8 per cent of sales, but Elcoteq had since suffered a number of setbacks. In 2005, BenQ of Taiwan had acquired the mobile phone division of Siemens, an important Elcoteq customer, and closed it down a year later. When the network operations of Nokia and Siemens merged in 2007, two Elcoteq customers became one. In 2010, Elcoteq obtained a contract to produce mobile phones for Sharp, which itself was under contract to produce Kin handsets for Microsoft, but the Kin was taken off the market after just six weeks. Elcoteq received some compensation for this, but no new business appeared. It became steadily more dependent on Nokia, and its financiers and directors complained repeatedly about this.

'Elcoteq was a global operator but backed the wrong horse', says François Pauly, a member of the company's board of directors between 2008 and 2010. In his interview, he notes that Elcoteq 'should have concentrated on Samsung, Apple and HTC [but] by 2010 we hadn't worked with any of these. There were some links with Apple, but not enough. The first iPhone order was for 10 to 15 million units, but Foxconn received the specifications just six weeks in advance. 'Only Foxconn could manage that', Pauly continues.

Jan Kotka, who worked in different positions in Elcoteq from 2004 to 2012, seems exasperated to be asked about the company's dependence on Nokia. 'It is easy to criticise us [but] I know how hard we looked for new customers. Of course we got some, but they were mostly small ... We knew that if Nokia disappeared we could not keep all our factories going', Kotka says in his interview.

Business with Nokia had been very profitable; for a long time, it supported the whole of Elcoteq. In 2006, Elcoteq's Nokia business ran on negative working capital, says interviewee Timo Seppälä, meaning that Nokia was financing Elcoteq's other operations. Then came a sudden halt. Between April and May 2007, Nokia stopped purchases from Elcoteq, just a month before new Elcoteq investments, demanded by Nokia, were due to come on line. In a year, net sales dropped by $€ 800$ million and the company made 
a loss of $€ 123$ million. Elcoteq's entire business with Nokia, worth over $€ 2$ billion, was reduced to zero in 2007-2008.

Then came the global financial crisis of autumn 2008. Financing costs soared and Elcoteq's banking syndicate announced that, whatever it had said earlier, it did not intend to renew the tranche of working capital that was about to expire. Moreover, one of the financiers, the Royal Bank of Scotland, had been rescued from bankruptcy by the British government on the condition that it withdrew rapidly from all operations outside the United Kingdom. This is one of the key reasons why Elcoteq, Europe's largest electronics contract manufacturer, filed for bankruptcy only three years later in 2011.

Nokia's decision to dump Elcoteq set off a chain reaction in which Ericsson and RIM also reduced their orders in order to minimise risks. Elcoteq's decline was therefore a steep one. In four years, three-quarters of its turnover disappeared. In 2009, Ericsson's representatives said bluntly that it would be too dangerous to do business with such a weak company. It purchased Elcoteq's operations in Tallinn, Estonia, and began its own production there. 'Ericsson was an excellent customer and, even at the final stage, behaved properly. Everything was transparent and straightforward', said Elcoteq executive Henry Sjöman in his interview.

Now began a series of negotiations between Elcoteq and its syndicate of financiers. The steering group consisted of SEB, Danske Bank and the Royal Bank of Scotland. However, the syndicate included other European banks and also Pohjola from Finland. In 2009, when Elcoteq still had 19,000 employees, the syndicate demanded that the company issue almost 2 billion extra shares. Elcoteq refused. Various other attempts were made to save it, but they failed. The three founders of the company, Antti Piippo, Henry Sjöman and Jorma Vanhanen, owned around 43 per cent of the shares but 85 per cent of voting rights, so no decision could be made without their agreement.

In April 2010, the syndicate forced the founders to convert their shares with more voting rights to common stocks. Now their control over the company was lost to the banks. Piippo and Sjöman 
also lost their seats on the board. The negotiations became increasingly acrimonious, and the bankers' poor opinion of Elcoteq's Antti Piippo were obvious. In their view, Piippo had taken an extraordinarily high salary from the company. One negotiator for the banking syndicate said in their interview: 'Over the years too much capital had been pumped out of Elcoteq. It was a mistake to operate on the basis of a long-term loan. Elcoteq needed a capital injection. After that the banks would have been more patient.'

Talks ended in summer 2011, when the banks took control of Elcoteq's money flow. Bank accounts were frozen and account balances used to offset against the loans. Customers and suppliers received a letter from the banks demanding that all payments should be made to the banking syndicate. No disbursement could be made by the company without the banks' approval. It was the last nail in Elcoteq's coffin. 



\section{Factory Exodus to China}

Nokia will soon be able to celebrate 100 years of doing business with China. The company was already selling timber to China in the 1930s. In 1985, it began producing Wellington boots and cables in China. The rubber boot machines had been part of Finnish development aid. Even the stamping machines were unchanged. Ollijuhani Auvinen, a journalist from the Finnish commercial television channel MTV3, pointed out that when he visited a factory in 1986, each boot was still being marked 'Made in Finland'. On the return flight, Nokia's CEO Kari Kairamo told Auvinen of his vision of a wireless future and mobile communication (Auvinen 2013).

When I visited China in spring 1987, the Nokia office consisted of a suite in the capital's only luxury hotel, the Beijing. The Nokia veteran Topi Honkavaara had established the office in 1985, and was achieving astounding growth. Dan Steinbock notes that Nokia's net sales in China were US\$180,000 a year when Honkavaara arrived. By the start of the 1990s, they were over US\$460 million (Steinbock 2005).

China was on its road to state-led digital capitalism led by investments in digital technologies (Hong 2017b). The official China enables economic development through broad strategies and by structuring the environment in which opportunities are found, ensuring both economic growth and the power of the ruling party. 'In the minds of China's leaders, this pair is inextricably 
linked: economic development must be maintained to ensure continuing support for Communist Party rule, while Communist Party rule provides the national stability necessary for development' (Tse 2015: 77).

In 1997, China reached a major milestone when the country's first official GSM phone call was made on a network supplied by Nokia. The first text message using Chinese characters was sent at the same time. Kairamo's vision had come true in China, too. Nokia had become a truly global company.

China had embarked on a massive telecom roll-out, from having no private telephone lines to the new world of mobile networks in just 10 years by China Telecom, China Mobile and China Unicorn, with the help of international providers of hardware and services (Tse 2015). In 1999, a vast mobile handset factory was completed for Nokia in the city of Dongguan, southern China. This area in the Pearl River Delta is China's fourth-largest export centre and, during the time, the Nokia factory was its most important plant in the region. In the middle of the 1990s, Nokia had realised that China would become a large market area for its phones. Sari Baldauf, who, between 1995 and 2005, was in charge of the networks business, was sent to China to establish more units and Jorma Ollila visited the country as frequently as possible. Ollila was even given an honorary citizenship of Beijing in 2002, as a symbol of his importance. 'If a company wanted to know what is happening in the markets there, the chief executive had to meet politicians, officials, and the managers of Chinese companies - that was the only way to make the contacts every company needed', he writes in his memoirs (Ollila \& Saukkomaa 2016: 331). According to his own account, Ollila visited China 52 times.

As detailed previously, Nokia's long-range plan was to lower its costs by shifting its subcontractors and contract manufacturers from Finland and other countries to China and India. Jorma Ollila and his team were to create the world's most efficient production machine for electronics. Mass production of cheap handsets would be given to contract manufacturers and Nokia itself would concentrate on more sophisticated models. 
Shifting production to China was a lengthy process, but, by the end of 2005, Nokia had 4,700 employees in China at four of its own factories and five research and design centres. Even in 2003, Nokia was China's largest foreign investor and its biggest manufacturer and exporter of mobile phone equipment. But without Foxconn and its main shareholder Terry Gou, it is unlikely that Nokia would have ever achieved a 40 per cent share of the global market. (Terry Gou or the company are not, however, mentioned in Ollila's memoirs.)

In 2020, Foxconn was the world's largest contract electronics manufacturer, with a recorded revenue of more than $€ 150$ billion and net income of more than $€ 4$ billion in 2018 when it employed 863,000 staff (Hon Hai 2020). The first concrete contact between Foxconn and Nokia was apparently at the end of the 1990s, although Nokia buyers must have known about Foxconn far earlier, because its first manufacturing plant in mainland China had been opened in Longhua Town, Shenzhen, in 1988. In 1999, Petri Väinölä had just arrived in Hong Kong from Finland to handle Nokia's procurement from Asia. In his interview, he explains that he received an invitation to dinner from an unknown caller, who turned out to be Terry Gou, the founder of Foxconn and already one of the 100 richest people in the world.

Over supper in Tsim Sha Tsui, a nightlife district in Kowloon, downtown Hong Kong, the two men gradually got down to business, including discussing sustainability of the supply chain and prices of plastic parts. Väinölä thought that the prices mentioned were high and according to the Nokia representative, 'Gou replied: "What are you willing to pay?" I didn't realise that they could make losses for as long as it took, until the competition gave up', he said in his interview for this book.

Next came an invitation for Väinölä to visit the Longhua factory. 'I went into a hall. There were 150 injection moulding machines. He asked if I could hear anything. No, I said, it's all quiet. "Yes", he said, "we have a problem. They're not running. These are Nokia's machines. We bought them for Nokia”. I said: "That's crazy. You 
haven't got a contract. We haven't even studied what you can do"', Väinölä continues.

At Väinölä’s request, Nokia sent a team to Shenzhen to investigate whether Foxconn could live up to its promises. The result was encouraging. The employees proved to be extremely competent. Foxconn had used high wages to attract Japanese engineers to its plants. At the turn of the millennium, Nokia ordered a batch of plastic parts from Foxconn, and larger orders followed within a few years. It was the start of a business relationship between the world's largest phone maker and an ambitious subcontractor. It also marked the beginning of the decline of Finnish subcontractors and, with the lag of a few more years, the decline of Nokia itself.

At the same time, the deal marked the start of China's rise to the top of the mobile world and the global success of state-led digital capitalism. In the 1990s, ICT-export-oriented manufacturing was developed with the help of foreign investments and was dependent on millions of disciplined but wage-depressed workers (Hong 2017a). Standardisation of mobile communication was an important part of that plan. Nokia and Ericsson lobbied China to adopt the 2G standard of GSM, while American Qualcomm, backed by the US government, successfully pushed for the CDMA standard. However, eager not to let foreign companies rule, the Chinese government in 1999 and 2000 started its importsubstitution policy in mobile communications. At this time, the only domestic vendors, ZTE (formerly Zhongxing Telecommunication Equipment Corporation) and Huawei, also emerged, but had limited success in penetrating the national market, which forced them to look for opportunities abroad (Hong 2017a).

Over the years, other Chinese subcontractors made contact with Nokia. The BYD company was established in Shenzhen in 1995, to make accumulators. It set up a subsidiary, BYD Electronics, in 2002, and in a few years it became the world's largest supplier of mobile phone batteries with a 50 per cent market share. Foreign companies like Nokia were encouraged to invest in local production and local subcontractors; if they did, they were given useful 
recommendations and support by Chinese officials. This was one reason why Nokia began cooperating with BYD.

It also needed a competitor for Foxconn so that it would not be too dependent on one supplier, with the risks this entailed in case the company failed. Despite a poor start, BYD managed to improve its processes so much that, in some products, it surpassed Foxconn to become Nokia's number one supplier. When it received a listing on the Hong Kong Stock Exchange in 2002, its financial resources improved and it was better able to meet Nokia's demands.

At the start of the 2000s, Nokia sent a team of engineers to BYD's factories in Shenzhen to help start up production. One of the team members says in his anonymous interview that BYD always took the easy way out in meeting Nokia's demands. 'When production was almost ready to begin, we made an inspection in which we recorded every failing that needed to be corrected. BYD always took shortcuts wherever it could. In contrast, there was no point inspecting Finnish subcontractors like Savcor because everything was always in order'

Nevertheless, the Chinese also had an entirely different attitude towards collaboration. 'There was absolutely no arrogance. Finnish companies could learn from this. There's no point making things difficult for the customer', the team member continues. Cooperation with BYD increased rapidly, and by 2007, two-thirds of its net sales came from Nokia batteries and chargers. There were problems, though, and in 2009, Nokia had to recall 14 million chargers because of the risk of fatal electric shocks. The charger had been a product that BYD had not made before it was ordered by Nokia.

There is a high risk of industrial espionage in China: the country is considered a leading threat when it comes to the theft of intellectual assets, including inventions, patents and $\mathrm{R} \& \mathrm{D}$ secrets (Hannas, Mulvenon \& Puglisi 2013; Roper 2013). Nokia technologies and factories were copied down to the tiniest detail. It was probably the greatest ever transfer of technology and knowledge from Finland to another country. China specialises in reverse engineering, where the product is disassembled so that the shape 
and function of each part can be recorded. South Korea marched into the world market in the 1960s using reverse engineering, but the Chinese took the art to a new level. BYD's accounts reveal extraordinarily little spending on research and product development, which ought to be a warning light. One Nokia engineer said in his interview: 'Why should it have invested in R\&D? It got everything it needed from us and others.'

Although BYD had hardly any knowhow of its own regarding the complex production of mobile phones, it obtained Nokia and Motorola as its customers within a couple of years. The abovementioned Nokia employee who worked with the company realised what cooperation meant. 'In the corner they had a 3-D machine in case the item [they were copying] could not be disassembled.'

Nokia was not only allowing its knowhow and technology to be transferred to China; it also appeared unconcerned about its subcontractors' intellectual property rights. Hannu Savisalo of Savcor, who is a specialist in producing plastic shells, says Nokia even gave Savcor's technical drawings to the Chinese. 'When Nokia asked for a bid from us, the drawings we supplied were leaked. Nokia hadn't even bothered to remove our name from them, let alone worry about who owned the rights to them. There was a hell of a fight', Savisalo recalls in his interview.

Ericsson markets its mobile networks by emphasising that the development work and manufacturing is done in Europe. This plays well with US and Japanese customers, who are concerned about Chinese efforts to obtain sensitive data. Huawei, a competitor to Nokia and Ericsson, had troubles being admitted to the US market, which under President Donald Trump has been closed altogether. In May 2019, the president declared the threat to US telecom networks a national emergency. Trump issued an executive order banning US telecom companies from installing foreignmade equipment that could threaten national security. The order instructed Commerce Secretary Wilbur Ross to prohibit transactions posing 'unacceptable risk to national security', but did not mention one company or country (US Department of Commerce 2019). However, China's industry leader Huawei probably came to everybody's mind. 
China's fast rise to the global top of internet and mobile communications was in the beginning only possible through copying and imitating, which is actually an important part of all innovation. However, until recently, there was agreement that whatever technical development happens, it is based on stealing intellectual properties. In 2014, Harvard Business Review published an influential article, 'Why China can't innovate' (Abrami, Kirby \& McFarlan 2014), which enforces this perception. In 2020, it sounds absurd, even though accusing Chinese companies of unfair competition is the main argument of the US government under President Donald Trump. For instance, the investor and Google China funder Kai-Fu Lee notes that, at one stage, Chinese companies were seen as copycats and often labelled 'the Amazon of China' or 'the Facebook of China', but they have already passed tech giants from Silicon Valley when it comes to implementing new ideas (2018: 22-50).

What was it like being a Nokia engineer in China? I have heard accusations that Foxconn and BYD put improper pressure on Nokia contacts to make them more cooperative. These stories would be less credible if they came only from the mouths of disgruntled Finnish subcontractors. One former Nokia employee told in his anonymous interview of photos taken in a karaoke bar in China that were later brought to Nokia headquarters in an attempt to blackmail. Other former Nokia managers say in interviews they have heard of bribes being paid to key personnel, but that these are just rumours and impossible to verify. Nokia officially condemns corruption, but there is obviously a fine line between dishonesty and golfing trips, the loan of a private plane or other gifts.

In mass production of electronics, value is created by very large volumes. A few years ago, Finland's Etla studied the value-added structure of Nokia's N95 phone (Ali-Yrkkö et al. 2011). When it was launched in 2005, it was the most sophisticated smartphone in the world. Nokia has a policy of not publishing information about components, software or the price of patent rights, so the Etla team took the telephone apart and began to investigate its elements. The results were interesting. Only 2 per cent of the final 
value of the phone was created at factories in China, whereas 39 per cent ended up in Finland via royalties and trademark licensing. In official trade statistics, China is the world's largest exporter of high technology, but the reality is that the value-added in China is still small (Xing 2014). Etla's study showed, in the mid2000s at least, that the country was still some way from becoming the world's leading economy.

The same phenomenon shows in Finland's trade statistics. When mobile phone exports began to decline towards the end of the 2000s, figures for service exports showed an upward curve. A large part of this revenue was in the form of internal invoicing for use of the brand. Nokia charged its foreign subsidiaries, in China and elsewhere, for using its name. China's leadership has understood the concept. Dominance in production does not last forever, if wages rise rapidly and erode price competitiveness.

In response to rising wages, Foxconn embarked on a high degree of automation and began to manufacture its own industrial robots. In 2014, however, the plans were cancelled after tests showed that the robots could not work as precisely as people. Apple forbade the assembly of its iPhone using 'Foxbots', although there are industry reports of robots still used to rotate screws, polish metal and package products (Whitwam 2014).

For Nokia, China was becoming an important base for manufacturing, but just as important from a market perspective. In 2010, the operating system Symbian had a market share of 64.1 per cent-divided mainly between Nokia and Samsungwhile Android was far behind at 5.4 per cent and Apple's iOS had only captured a share of 4.1 per cent (Hong 2017a).

Globalisation treats everyone with equal severity. In 2014, Microsoft acquired Nokia's factories in Dongguan and Beijing and began to scale down mobile phone production there. The machinery was transferred to Vietnam, where wages were lower. At least 9,000 Chinese employees were laid off. Now, the Dongguan factory stands empty and crumbling. The reorganisation was part of Microsoft's plan to reduce by 12,500 the number of workers it inherited from Nokia. Plants in Komaron in Hungary and Reynosa in Mexico were reorganised at the same time. 
Foxconn and BYD continue to thrive with its extremely lowprofit business model. Nokia was not the foundation of Foxconn's success, but certainly contributed to it. At the time of writing this book, Apple accounts for half of Foxconn's turnover, which manufactures two-thirds of Apple's mobile devices (Chan, Selden \& Nqai 2020). The rest of Foxconn production is for Cisco, Juniper, HP, Huawei, Dell and-from 2020-Nokia.

Jean-François Baril continues to be the person connecting the dots between Nokia and Foxconn. In 2011, he left Nokia after almost 12 years in charge of sourcing and procurement. After that, Barril worked as a special adviser to Terry Gou, while at the same time continuing to do business with his former Finnish colleagues such as Anssi Vanjoki. In 2016, he surfaced as the founder of HMD Global, a new company that negotiated a 10-year exclusive licence to produce and market Nokia-branded mobile phones. The company is registered and headquartered in Espoo, Finland, and is formally owned by Smart Connect LP, a private equity fund managed by Baril. The deal was made possible when Microsoft wrote off the loss-making mobile phone business it had bought from Nokia in 2013. 'In fact the true creator of HMD is Stephen Elop. I'm a bit sarcastic but he created all the conditions for getting the asset of Nokia to be so cheap', says Baril in his interview.

Initially, Nokia-branded phones were manufactured by Hon Hai Precision Industry Co.s other subsidiary FIH Mobile, but the company experienced loss-making operations due to the limited success of Nokia phones, which are now also produced by other subcontractors.

In blogs and on social media, such as Reddit, unsubstantiated rumours have been spread that Hoi Han actually owns HMD Global. One piece of 'proof' is that the chairperson for the first years was Sam Chin, Terry Gou's right-hand man, until he stepped down in August 2020. This ownership connection is denied by Baril in our personal communication, but FIH Mobile is an investor in Baril's other company, Ginko Ventures. In the interviews for this book, several people speculated that Baril's secret mission when he came to Nokia 20 years ago was to capture and transfer the mobile phone business to Foxconn, an accusation Baril does 
not take lightly. In retrospect, Foxconn has actually taken over the operations since Microsoft sold Nokia's former feature phone business to FIH Mobile in 2016 (Microsoft 2016), and now also manufactures Nokia-branded smartphones. However, it is very hard to see this as the logical end-goal of a master plan.

To summarise, China's state-led digital capitalism, the fast march from ICT subcontract manufacturing to the world's biggest hub for advanced mobile phones, largest investments in 5G and artificial intelligence technology, is nothing less than amazing. ICT and AI are now at the core of the government's development plans (Hong 2017b; Lee 2018; Murgia \& Gross 2020).

This chapter has shown how Nokia, as a key player, has contributed to that massive economic and technological transformation over the past 30 years. During that process, the Chinese communications industry has become one of the most important drivers of the domestic economy, with global effects as well. 


\section{Shattered Dreams: India}

This chapter shows how India became an important market for Nokia, and at the same time, India served as a Nokia site for research and development of new features that could be marketed around the world. Can whole countries be Nokia's stakeholders? I would say yes, at least when it comes to India, where Nokia jumpstarted the digital communication revolution.

Josh Foulger, a Nokia executive in Chennai before he moved to Foxconn in 2015, says in his interview that Nokia had already begun to study India in the mid-1990s. In 1995, India’s first GSM call was made on a Nokia handset on a Nokia network.

The entrance to the Indian market was a partnership with HCL (formerly Hindustan Computers Ltd) in 1994. Being ahead of the curve was a key component of Nokia's strategy. 'We invested before everybody else-in the brand, in people, in distribution, explained D. Shivakumar, Nokia India's Vice President and country manager (Knowledge@Wharton 2007).

In 2000, prior to establishing its own factory, Nokia acquired a number of local Indian SMEs. A good example of such a company is Ramp Networks, established by Sridhar Bathina in 1993. Ramp specialised in network traffic security for small offices. Ramp became part of Nokia in 2000, and within a few years, its research unit had grown from 27 employees to 120 .

Because of Nokia's early start in India, the company obtained a strong market position throughout most of the country. 
However, the high customs duty on mobile phones was a hindrance for market expansion. By 2001, Nokia had opened 80 sales points in India in the hope that the 'luxury tax' would be reduced. Nokia was strongly hinting, and the Indian government understood, that no foreign manufacturer would begin operations in the country before there was a decent native market. High taxes are also a barrier to higher penetration of phones (James 2016). Most handsets were imported illicitly from Singapore and there were only 10 million connections. When the customs duty was reduced from 25 to 5 per cent in 2000-2001 (IGI Consulting 2000), growth was enormous. Three years later, in 2004, more than 50 million Indians were using mobile phones (Singh 2008).

This reason behind the success is intriguing: was Nokia successful in lobbying for the tax cut, was the company tipped off that the tax cut was coming, or was it just pure luck? 'Company management was committed and well informed about conditions in India', Foulger commented diplomatically.

There is a range of academic studies on how mobile phones helped farmers grow their business (Mittal \& Mehar 2012), the fishing industry coordinate its operations (Abraham 2006), or provide health services in rural areas in India (DeSouza et al. 2014). Nokia handsets were technically suitable for variable climate zones, which was also realised by Mohammad Yunus, later a Nobel laureate. Yunus had established the microcredit institution, Grameen Bank, in 1983. With the assistance of the Norwegian operator Telenor, Yunus established the 'Village Phone' project in 1997. The goal of the project was to help women in remote districts become phone resellers with Grameen microloans. When I met Yunus for a newspaper interview at his Dhaka office in 2001, he said that only the Nokia 1611 could survive the humidity of the local climate. Initially, Grameen had used Siemens handsets, but they did not last.

In 2006, Nokia established an entire industrial district, Sriperumbudur, on the outskirts of Chennai. Finnish subcontractors, such as Perlos, Aspocomp and Savcor, also located in the same district. Chennai has long industrial traditions based on vehicle 
manufacturing. In Indian terms, the Nokia factory was erected in record time; production began just 23 weeks after the start of construction. Nokia had the world's most advanced production machinery.

The contract manufacturer Elcoteq had established a factory in India in 2005, but, strangely enough, in Bangalore, not Chennai. According to people interviewed, Nokia management had demanded commitment from Elcoteq, so the company decided to invest before its main client did. Its choice at that time was between Goa, Mumbai and Bangalore (officially Bengaluru). Nokia had not promised to buy output from Elcoteq in Bangalore and, in the end, it did not.

But while Elcoteq had made its decision and built the factory, Nokia postponed its own choice on where to build a new factory while it pored over world maps. The alternatives were Dubai, North Africa and India. It wanted to export production to East Africa, because West Africa could be handled from Europe. For this reason, one of the criteria for the location of the plan was an adequate airport that could be used to ship phones to Africa.

The problems for Elcoteq in Bangalore began when Nokia management heard that Elcoteq had been dropping Nokia's name in its negotiations with authorities in Karnataka, the state of which Bangalore is the capital. Elcoteq achieved the tax breaks it wanted, but according to people interviewed, Jorma Ollila and his executive team were displeased about the unauthorised use of the Nokia name. No deal with Elcoteq was ever made and, as we heard, relations were already turning sour.

In November 2006, Finland's Prime Minister Matti Vanhanen travelled to Sriperumbudur near Chennai to inaugurate the Nokia plant. It was good business for Nokia because the hourly wage rate of Indian workers was well below one euro. The vision was to produce 1 billion mobile handsets at the world's largest factory, but it was a mirage. The last phone bearing the Nokia name was assembled in Chennai at the end of October 2014. The success story had ended in just over seven years. 
The decline was a steep one. As recently as 2011, Nokia still controlled nearly 40 per cent of the market. By 2015, only the poorest segment of the population was interested in Nokia and its cheap but durable phones. That year, I was visiting the southern Indian city of Chennai. My driver stopped his tut-tut rickshaw by a small kiosk in the shade of a banyan tree. The kiosk was really just a hole in the wall under a great banner for the Korean mobile phone manufacturer Samsung. The Nokia name was less prominent, but still there. Abdul Samad greeted me. He had been running a business at this kiosk for 10 years and was a walking encyclopaedia about his country's short history in mobile phones.

'Nokia still sells, but only its cheapest models. The most expensive are Samsungs running Android', he explained. The cheap, Nokiabrand handsets used the old S30 operating system. Otherwise, Android was dominant in India. Only the wealthy might consider a Microsoft Windows phone. He said, 'Poor people have not heard of Microsoft at all.'

Handset sales in India were dominated by small tradesmen like Abdul Samad. Nokia had up to 600 large Indian distributors, but they supplied phones to 300,000 tradesmen, who were everywhere. I bought one of Nokia's last original phones from Abdul, a Nokia 105, manufactured in Vietnam. A young man aged about 15, hovering around the kiosk, asked where I came from. 'From Finland', I said, 'You know, the land of Nokia.' He shook his head and took off.

Mobile phones and digital communication are key to India's technology revolution. India is the second largest mobile phone market globally, next only to China. At the end of 2018, the estimated number of smartphone users in India was 337 million, compared to 2.53 billion users worldwide, according to Kathuria, Kedia and Bagchi (2019).

Just as smartphone sales were starting to soar in India, Nokia had ceased to be a player, and was instead concentrating on selling networks to operators. The Nokia brand was still number one in 2011, number two in 2012-2013 and number three in 2014, but disappeared after that (Kathuria, Kedia \& Bagchi 2019). The 
reason is simple: after acquiring Nokia's mobile phone division in 2013, Microsoft began to remove traces of the Nokia name from India in spring 2015. Nearly 9,000 Nokia stores and more than 100,000 service points were given new Microsoft logos. Some began to sell game consoles and Windows tablets in addition to Lumia phones. Of Nokia's own stores globally, the greatest number were in India. Around the world, nearly 16,000 stores were renamed. Microsoft had acquired the Nokia mobile phone business and hoped to conquer the world under its own brand. In India, it would not happen.

Already in 2015, Vietnam had become the new base for cheap production after wages in China and India rose too high. In Chennai, this meant that, by the end of 2015, more than 8,000 Nokia workers had left its factory and subcontractors were also dismissing staff. In a hall that had recently held 35,000 to 40,000 workers, there was now hardly anyone. Outside the gates, some of the 1,700 workers dismissed by Foxconn were demonstrating. It was not safe for an outsider. Today, only the skeleton of the factory remains, since the machinery has been sold to Foxconn.

\section{Nokia Nomads}

Nomads are people who move often to different locations, frequently as a lifestyle choice (Schlagwein 2018). Digital infrastructures and mobile devices have enabled new forms of flexible and remote working (Nelson, Jarrahi \& Thomson 2017). The vision of Marshall McLuhan has become true long ago. He pictured inhabitants in the 'global village' (McLuhan 1962), a metaphor for the reduction of physical distances throughout the world due to new information technology. A specific species of nomads in the global village is what I call Nokia Nomads. These transnational cosmopolitans seem free of spatial constraints. Nokia was-and still is-a truly global company that created a new community, the class of Nokia nomads, a new class of frequent flyers (Calhoun 2002) sent abroad to work for the company. Some never returned home. Others, who came to Finland or were on the company's 
payroll somewhere in the world, carry with them the same sense of belonging.

I met Jan Blom, a user design expert and researcher, in Bangalore, southern India, in 2006. Nokia phones were hot items, and Blom had left Finland with his family to create and manage a team studying the lives of the poor and how they used mobile handsets. The office was opened in 2007 and situated next to the Srishti Institute of Art, Design and Technology specialising in novel service opportunities for Nokia in India and in emerging markets in general. One of the solutions Nokia was seeking was for people who could not read or write, and needed text to be replaced with symbols and sounds. Bloom's team also created the Healthradar application, which aimed to trace and prevent outbreaks of disease, something that many tech companies have been trying to accomplish in today's Covid-19 crisis.

After many years in global positions at Nokia, Jan Blom ended up at Google in Mountain View, a typical career move. Silicon Valley companies have recruited many former Nokians. Luca Maestri, Apple's Chief Financial Officer, is another of the many people who used to work for the Finnish company.

Another Nokia nomad is Jan Chipchase, who later set up his own consultancy in San Francisco. His book Hidden in Plain Sight (2013) is about consumer research in the poorest parts of the world. Chipchase was one of the first to notice that Ugandans were making payments by exchanging phone credit, creating unofficial digital banks. In many developing countries, phone credit can be transferred between users and converted into cash in poor districts that lack banking services.

'I did not invent mobile money', Chipchase says in his interview. 'Others invented ways of using it and I studied their methods.' His observations convinced Nokia to establish Nokia Money, together with Carol Realini of California, who had founded Obopay in 2005. In 2009, Nokia acquired Obopay for US\$35 million and launched Nokia Money in India the following year. It did not catch on, partly because of India's strict money market laws, and was shut down in 2012 . 
Another discovery by Chipchase and his ethnographic research colleagues was commercialised far more slowly. It was not until 2010 that Nokia started selling a dual-SIM mobile phone, although Benefon, another pioneering Finnish mobile phone maker, had already demonstrated this in 1999. Chipchase's group realised from field studies in India that two SIM cards allowed priceconscious users to pick the cheapest operator and the best reception at any given time.

Chipchase's team played an important part in developing the Nokia 1100 model, launched in 2003, which sold 250 million units. The team had realised in the slums of Mumbai that a phone needed a torch in poor lighting conditions and a plastic shell to resist dust and moisture. Chipchase's team also created the speaking alarm clock in the Nokia 1600, and the Wake-up India advertising campaign. 'It may sound trivial but for them it was groundbreaking electronics', Chipchase said in his interview.

Blom and Chipchase are just two examples of thousands of former Nokia employees who can be found all over the world. There are 265 groups around Nokia on Linkedin connecting over 600,000 people. The biggest of them, Nokia Global Alumni, has more than 20,000 members.

You will find more than 25,000 Nokia nomads in the closed Facebook group founded in 2011, 'Beyond Nokia', which accepts everybody who has worked or is still working for Nokia. According to the administrators of the Facebook group (Clive et al. 2020), the unifying spirit of the place is that: 'Nokia brought together a diverse range of people, united by a mission to make the world mobile. Post Nokia, we belong to an amazing network of people, all connected-no borders.' Messages on Beyond Nokia convey a sense of belonging and collective pride over achievements, but also a sense of great loss. 



\section{The Tale of Two Cities}

Various parts of Finland, especially the metropolitan region around Helsinki and the northern city of Oulu on the Gulf of Bothnia, have developed in Nokia's wake over the years. These cities were transformed into the high-technology centres of northern Europe in the course of a few decades.

\section{Espoo}

In 1989, Nokia signed an agreement with the municipality of Espoo, obtaining land for its head office on the coast at Keilaniemi, west of Helsinki and looking across the bay towards the capital. The media was strongly critical of the deal, believing that Nokia had no real intention to build there and was looking to resell the land at a profit.

After appeals against zoning were exhausted, building work finally got underway in 1993 and the first stage was ready in 1997. With Nokia's move out of town, Helsinki lost hundreds of millions of euros in corporation tax. It was a giant win for Espoo.

'We were in the midst of a deep depression. Thanks to Nokia, we obtained an entirely new sector, the ICT cluster, which saved us from the worst of it by replacing lost jobs. Espoo began to grow fast', said former mayor of Espoo Marketta Kokkonen in her interview. 
The rise of Nokia's Keilaniemi headquarters symbolised the start of Finland's period of globalisation. The building was designed by well-known architects Pekka Helin and Tuomo Siitonen, who exploited construction technology not previously used in Finland. It has won several architectural competitions. Its negotiating rooms were named according to the places where Nokia had local offices: London, Stockholm, Peking, Manila, Shanghai, Rome and Madrid.

The basis for Espoo's success was laid by Helsinki University of Technology, which had a large campus there in Otaniemi, and the VTT research centre, also based in Otaniemi. But it was Nokia that helped the municipality build its international brand, 'High Tech City'. Since Nokia's move, it has provided land for the head offices of other major corporations such as Kone, Fortum, Neste Oil and Gasum, not to mention Microsoft. The Otaniemi area, which contains Keilaniemi, is the largest research and information technology centre of northern Europe, with 5,000 researchers, $25 \mathrm{R} \& \mathrm{D}$ units and 16,000 students.

Espoo benefited not only from tax paid directly by Nokia, but also from the municipal taxes paid by Nokia employees who lived in the municipality, including Jorma Ollila, Olli-Pekka Kallasvuo, Simon Beresford-Wylie and Anssi Vanjoki. Between 1999 and 2008, Jorma Ollila alone paid municipal tax of more than $€ 21$ million.

Success builds success. Many foreign experts in technology and finance moved to Espoo to get Nokia's name on their CVs. The company was a magnet for foreign talent. Before Nokia, Espoo was partially a rural idyll and partially a dormitory suburb. Now it has its own profile and its strength is comparable to Helsinki's. 'It's like the difference between Boston and Cambridge in the US', says interviewee Ari Huczkowski, head of Espoo Innovation Garden, a project to attract businesses and start-ups to the Otaniemi area. 'When you go across the river from Boston to Cambridge, you move to an entirely different culture and atmosphere. It's the same when you cross [the bay] from Helsinki to Espoo, Huczkowski continues.

Espoo also suffered since 10,000 people worked for Nokia in the early 2000 s, but only 3,500 by 2015 . But, its employment 
structures were more diverse than another Finnish city that was hard hit by Nokia's failure followed by layoffs: Oulu.

\section{Oulu}

Nokia's story in Oulu began in 1973, with the production of radio phones for the Finnish defence forces. Nokia received the order on the condition that production would take place in a developing area, and so the factory was built in northern Finland. At the same time, the company began cooperating with the local university, the University of Oulu, to train engineers. The collaboration expanded into research and product development.

The sale of Nokia's Mobile Phone division to Microsoft in 2013, and the end of production of basic Nokia handsets, brought a sharp reduction in the number of jobs in the field. The whole city was waiting in trepidation to hear what Microsoft would do. Until May 2014, the Oulu mobile phone development unit was owned by Nokia. In August, more than a thousand jobs were under threat and many taxpayers were soon to be dependent on social services. At the same time, another major employer in the city, Broadcom Corp. of America, was ending modem production in Oulu, leaving 600 people without a job. That unit was also previously owned by Nokia. The upheaval of these changes, and the problems of local businesses, affected an estimated 85,000 people in Oulu according to an interview for this book with Juha Ala-Mursula, CEO of Business Oulu. In August 2014, Oulu's local newspaper Kaleva was reporting that the city had decided to lay off all its employees for five days. The collapse in tax revenue had torn a hole in the city's purse. The cascade of tax revenue from Nokia had come to an end.

During the turmoil of 2014, I interviewed Professor Juha Röning of the Faculty of Information Technology and Electrical Engineering at the University of Oulu, one of Finland's largest universities. Over the years, Röning has supervised hundreds of master students who were to become Nokia engineers. At the end of the 1990s, the faculty started to train thousands of people for work in the IT sector to fill the skills demands of one 
big company. Somewhat jokingly, it became known as the 'University of Nokia', among both faculty staff and local decision-makers.

The spirit of scientific openness and Nokia's need for IPR protection created a conflict within the university as open access clashed with business interests, but it was resolved in a practical way: 'The tradition in our faculty was that all thesis work was published. It was just not available anywhere', Röning says in his interview.

By end of the year 2014, times were tough. The Finnish government had decided to provide $€ 50$ million to Oulu in the form of a support package to create ICT sector jobs lost in Microsoft's cuts. The target was 5,000 new jobs in Oulu by 2020. The University of Oulu, the local office of the VTT technical research centre and the Oulu University of Applied Sciences had all applied for funds from the state and wanted to be involved in creating new companies. There were also Tekes grants available from three different digital-business projects to be used for product development, internationalisation, piloting, user testing and risk capital.

Oulu was not the only place affected; in absolute terms, the worst hit was Salo, in western Finland, but it has only a quarter of Oulu's population. Salo is the birthplace of the mobile phone industry in Finland and was once dubbed 'Salocon Valley' (Lindén 2012: 13). Nokia's deal with Microsoft in 2013 led to massive layoffs and the place was left struggling with high unemployment and an exodus of former Nokia employees. The housing prices fell to rock bottom. The former mobile phone factory that brought so much wealth and work has now been converted into Salo IoT Campus, an 'Innovation hub for future technology solutions'. Salo has also entered a partnership with Huawei to create a 'smart city' and an 'IoT Campus', and the city openly markets itself as a safe haven for the telecom company accused by the US government of spying for the Chinese government (Paananen 2019).

Nevertheless, Oulu has already managed to make its comeback after just a few hard years. In the winter of 2015, I interviewed Juha Ala-Mursula, a former director at Nokia (1998-2009). Ala-Mursula, now Director of Oulu Economic Development, leads 'Business Oulu', a project to bring new jobs to the city. 'It's 
been a good autumn. We have managed to land skilled companies that pay good salaries', he stated. The attractions of Oulu, for new businesses, are the skill set of the population and a ready ecosystem of technology companies, along with the university. Another appealing factor is Oulu's cost level: wages are 40 to 50 per cent lower than in the United States. Northern Finland is also cheaper than Central Europe, or even the east coast of China. 'An Englishspeaking engineer with ten years of working experience costs less here than in Shanghai, Ala-Mursula continued.

Among the new-coming businesses were a German producer of software for the automotive industry Elektrobit, two semiconductor design companies-MediaTek of Taiwan and Nordic Semiconductor of Norway, and a payments division of Nordea bank. Nordic Semiconductor alone brought in 180 new jobs in just three years. The economic success can be traced in numbers: from 2015 until the end of 2019, exports from the region grew by 26 per cent and turnover in the private sector by one-quarter (Business Oulu 2020). There are more jobs in Oulu's ICT sector than when Nokia was doing well (Mäntylä 2017).

After the enormous structural upheaval endured by Oulu, it is no longer dependent on one sector, technology or company. If everything goes according to Ala-Mursula's plan, it will join the list of cities that have transformed themselves and survived, such as Eindhoven in the Netherlands, which is the hometown of electronics giant Philips, and Waterloo in Ontario, Canada, home to RIM, mostly known for the handheld computer Blackberry. Both suffered massive layoffs in the 1990s and 2000s, respectively. 'Of foreign companies setting up in Finland last year [2014], 60 per cent came to Oulu', Ala-Mursula said. '1,500 jobs have disappeared from Microsoft and Broadcom but I believe that, before next spring, 850 of them will have been replaced', he concluded. When looking at his vision from 2014 with a 2020 perspective, it seems amazing that someone in the middle of a deep structural economic crisis could muster so much optimism. That says something of the enduring and resilient spirit of the place that always seem to manage a comeback (Kulju 2002). 



\section{The Decisive Year}

Nokia executive Robert Andersson was in Thailand at the turn of 2008. He was responsible for global sales and production. 'I sat in a hotel room with my computer, monitoring delivery volumes and in touch with my managers around the world', Andersson said in his interview. At the time, Nokia was heading towards a landmark; if it sold only a few hundred thousand more phones, it would achieve 40 per cent global market share. It had had a glorious year in 2007 , with a record profit: $€ 7.2$ billion. Few could guess at this stage what 2008 would bring. It could have marked the start of new success. 'This was the very final moment for us to put all our energy into a new operating system for smartphones', Andersson says. Today (in 2020), he is President and CEO of Oriola Corporation, a Finnish health and well-being company.

In the language of business researchers, 2008 was potentially Nokia's innovation moment, the time window when a company has the opportunity to reinvent itself and its business model (Gassmann 2014). Nokia management knew that Apple and Google's Android was coming strong, but Nokia failed to achieve a 'sputnik effect', a term derived from America's furious and successful reaction to the Soviet Union's breakthrough in the race to the moon (Kao 2007).

Instead, 2008 came to be seen as the year that Nokia lost its way, like many other major companies over the years. Kodak, Commodore Computers, Polaroid, Digital Equipment, Grundig, Nakamichi, 
Newsweek and Nokia all had plenty of resources for development, the best talents and a clear view of the market. Yet, they failed to grasp their situation and make the right decisions.

Instead of seeking more profits and higher share prices, Nokia's executives should have concentrated on renewing their business model. They had the right preconditions: the best experts in the business and views backed up by a vast amount of data. By spring 2008, they already knew that Nokia was facing a very serious situation because six out of ten economic indicators were showing red according to an internal, confidential presentation I obtained from an anonymous source.

'Nokia management was like a flight director who sees everything from the control tower', says Jean-François Baril in his interview. 'At some point he must draw conclusions and believe firmly in them, but Nokia could not', he continued. Many others tell the same story.

Nokia managers had a strict line: they would not agree to invest in something new unless the product or service would immediately generate net sales of at least $€ 100$ million. That figure was derived from the costs of project launch, product development, productive investments and advertising. This principle, called fact-based management, became the cut-off point for all innovations with less potential. It represented, with hindsight, shortsightedness and it hurt staff morale; after management has rejected three promising prototypes or two new services, it is difficult for people developing new features with untested market potential to remain motivated. Nokia suffered from temporal myopia-a focus on short-term product innovation at the expense of longterm innovation development (Vuori \& Huy 2016).

Responsibility for Nokia's (in)action in 2008 as a whole fell on the shoulders of Olli-Pekka Kallasvuo while Anssi Vanjoki was in charge of operations. However, responsibility also falls on Kai Öistämö of the Devices unit and Niklas Savander of the Services unit. They took decisions on technical development and failed to allocate sufficient resources to create a new Nokia operating system to replace Symbian. Responsibility for the failure to reinvent 
Nokia must also be borne by the Chairman of its board, Jorma Ollila. Nothing happened without his say-so.

In 2005, when Nokia asked software architect John Ankcorn to work on Symbian, Ankcorn instead proposed developing an alternative operating system based on Linux, a family of open-source software. Within a couple of years, Ankcorn says in his interview, he was ready to propose how it could be achieved, but it was not until 2011 that he was given the go-ahead. Thus began the project to produce Meltemi, a system intended for the cheapest Nokia handsets with touch screens. It was not completed and Nokia axed it in 2012.

Work on another Linux-based operating system, Maemo, advanced further. A small Nokia team began developing Maemo for smartphones in 2005. Still, at the start of 2008, investments in Maemo were almost non-existent: just 3 per cent of all investments was funnelled into its development. Maemo was already late and Android was becoming the standard. When Maemo was renamed MeeGo after merging with Intel's Moblin in 2010 and investments rose in a massive way, the window of opportunity had already closed.

The N9, announced in June 2011 and released in September, was the first and only Nokia handset running on MeeGo. Many tech bloggers regarded it as the best phone that Nokia had ever made. However, in spring 2011, Nokia had withdrawn from the MeeGo project and consumers were wary of spending their money on a system that the manufacturer had already abandoned. John Ankcorn believes that the main reason why MeeGo and Meltemi both advanced so slowly was that the programming team was too strictly managed by the Nokia head office in Espoo. Ankcorn said in his interview that he tried to isolate the team by putting most of them in Germany. 'Unfortunately, they found us and destroyed us.'

Nokia also knew that the Symbian 60 touchscreens did not work and were causing an enormous drop in sales. The effectiveness and predictability of the Symbian 60 platform were poor in other ways, too. However, Nokia's army of Symbian developers and product managers did everything they could to fend off any investments in an alternative operating system (Doz \& Wilson 
2017). In addition, Nokia's long patent dispute with Qualcomm meant that few alternative chipsets were available which would have made development more effective.

There were several reasons why Nokia failed to move. One was a false sense of security, that the company had plenty of time. It had had an incredibly good year in 2007 , in practice the best ever, and the same was expected to continue. Then, in early 2008 came the wave of protests against Nokia at the Bochum factory in Germany. They took Kallasvuo by surprise and distracted him. Germany was an extremely important market area for Nokia and the domicile of Siemens, Nokia's partner on the Network side since 2007.

Aalto University Professor Erkki Ormala, former technology adviser to Nokia, says in his interview that the first weak signals that all was not well came when the financial emergency spread from the subprime mortgage crisis in the United States in 2008.

Nokia management was slow to recognise the iPhone's success and the threat it posed. Kallasvuo's first reaction was that it was a niche product, aimed at a narrow market segment: from a product perspective, it had poor voice quality and reliance on 2.5 GPRS connection (Doz \& Wilson 2017). GPRS (General Packet Radio Service) is a technology between $2 \mathrm{G}$ and $3 \mathrm{G}$ for faster data transfer. He was not alone in this assessment. The same thinking dominated Nokia's executive teams until the second half of 2008. Nokia's response, the N97 smartphone with a touchscreen interface, was not announced until December 2008 and was released in June 2009. It was technically an unfinished product and an enormous disappointment to Nokia customers. According to my interviews, management knew of its failings, with Symbian limitations and cheap standard components, but decided to release it anyway.

In his memoirs, Ollila notes that the warning signals were observable in 2009, but no one took them seriously. 'The company should have examined its working practices ruthlessly; instead we wrongly thought that Nokia's old recipes would continue doing their job. But the world had moved on' (Ollila \& Saukkomaa 2016: 351).

When Nokia held a Capital Markets Day in New York in December 2008, analysts and investors wanted to hear news about new 
phone models. With 39 per cent of the market, Nokia was the dominant player and was earning 69 per cent of all the profits in the mobile handset sector. The remaining 31 per cent was shared among Samsung, Motorola, Sony Ericsson, LG, RIM (Blackberry) and Apple.

Forbes, Wired, CNet and PC World all chose Nokia's E71 as the phone of the year, not the iPhone or HTC's Android-based Dream, known in the United States as the T-Mobile G1. The E71 had a qwerty keyboard and could make video calls. A billion people still used Nokia products every day, and the company manufactured 15 new handsets every second of the day. But, the economic crisis was now being reflected in Nokia's sales, which fell like a stone towards the end of 2008. There were a record number of order cancellations in December. The board was already worried in spring 2008 about Nokia's software and strategy, but it thought that the company would survive and that sales would improve in 2009. So they did, but only briefly. Already by 2010, the value of Apple's sales was overtaking Nokia's. As a challenger in the mobile phone business, Apple had smaller problems to adjust than a company with a huge legacy business, like Nokia.

Nokia's executives were not alone in their inability to see the threat they were facing. In 2007, Harvard professor and innovation researcher Clayton Christensen predicted that Apple would not succeed (interviewed by Nussbaum 2007). Fortunately, for Steve Jobs, Christensen was wrong. Seven years later, Christensen conceded in an interview that he had not understood what the iPhone represented:

There's a piece of the puzzle that I did not understand. What I missed is that the smartphone was competing against the laptop disruptively. I framed it not as Apple is disrupting the laptop, but rather [the iPhone] is a sustaining innovation against Nokia. I just missed that. And it really helped me with the theory, because I had to figure out: Who are you disrupting? (Bennett 2014)

The question is, did everybody realise the depth of the company's problems? It seems that crucial information was kept secret from parts of the board. Risto Siilasmaa had been a member of 
the board since 2008, and he became the chairperson in 2012 . However, not until 2017 was he informed about a study that Nokia's management had commissioned management consultancy McKinsey to undertake in 2007. According to Siilasmaa, the consultants assessed and provided ideas to improve the company's organisational efficiency. 'McKinsey's Organizational Health Index (OHI) is a methodology used by McKinsey on thousands of companies to evaluate the drivers - and detriments - to creating a high-performing culture. OHI enables comparisons between the companies and can help a company understand their organizational health relative to others' (Siilasmaa \& Fredman 2018: 123).

Nokia ranked in the bottom 25th percentile of the index, which was seriously bad news as there was a higher than 50 per cent probability for companies near the bottom to cease business within two years, according to Siilasmaa. This was again a cause of Jorma Ollila's asymmetric information management, further analysed in Chapter 5 of this book.

Petra Söderling, who worked for Nokia between 2000 and 2012 and was a director of the Symbian Foundation and Symbian Ecosystem, blames short-termism: 'We concentrated too much on quarterly results. This is understandable in a stock exchange company but some institutional investors look at a company over a ten-year period', Söderling said in her interview.

Under the leadership of Kallasvuo and Ollila, Nokia took a passive approach and made no real changes to its business model. Instead of promoting new ideas, it applied cost-cutting and extended this to the whole organisation. 'It felt as if every meeting was about costs, what was called the Bill of Materials, or BOM. We had to examine BOM in every way. Nothing mattered but BOM, BOM, BOM', Söderling continued.

Apple was losing no sleep over material costs. Steve Jobs' business model hinged on the user experience so beloved by customers (Isaacson 2012). Apple handsets used top-quality components and the material costs of the first iPhones were as high as the sales price of competing models. Jobs persuaded the sole US distributor of the first iPhones, telecommunications company AT\&T, to pay the bill of materials. AT\&T subsidised the iPhone by as much 
as US\$350 per phone, while its subsidies for models from Nokia and other competitors were only US $\$ 50$ to $\$ 150$. In the United States, operators dominated the telephone market and decided what models would be sold.

With shareholders pushing Nokia to hold on to the high market share, Nokia was constantly launching new handset models during most of the 2000s. Anssi Vanjoki's strategy of market segmentation had reached the point of absurdity. There were Nokia models for 'simplicity seekers', for 'life builders', for 'young explorers' and for 'technology stylists'. Management felt that mobile handsets had become basic, generic items, and its response was to differentiate them through marketing. New segments were published at 18-month intervals, with three-dimensional diagrams resembling a Rubik's cube. Consumers would be seduced into buying a new Nokia phone, customised by styling, colour, features and marketing to suit different user groups, real or imaginary.

At Apple, there were in my opinion only two consumer segments: those who believed that they could afford to buy an iPhone and those who felt they could not afford not to buy one. There was only one iPhone and it was black. Nokia smiled at this niche product, failing to realise that users would be satisfied with one model if it contained all the applications and services they wanted. The greatest innovation was not the phone in itself, but the ecosystems of services, the world of Apple (or rather a prison with products not transferable elsewhere) entered by the customer.

Kallasvuo must have realised this after a meeting with Steve Jobs in 2008. In the book by Doz and Wilson (2017: 117), he recalls: 'Steve Jobs told me he didn't regard Nokia as a competitor as we weren't a platform company. When I argued that we were investing in platforms he looked at me and said he'd been investing in a platform and OS for forty years and so he wasn't worried about our recent effort.'

What Kallasvuo perhaps did not understand was that Jobs was talking about platforms in a very specific way, as layers of software that started to organise the chaotic internet around 1995 to 1996. These platforms allowed an easier way for other companies to provide services to customers, while the platforms controlled 
the relationships. Thus, a platform consists of an operating system like iOS or Android and a business model.

Erkki Ormala believes, however, that the fundamental problem was Nokia's operating system, Symbian, which was hopelessly obsolete and almost useless in accessing new internet services. 'It's the age-old story. When new technology is born, the old system becomes history', Ormala said in his interview. This is one reason to fear old technology much more than new. In the 1990s, the change in the business was from fixed to mobile networks. At the end of the 2000s, Nokia needed to move again, into the internet age, but its new operating system MeeGo was seriously late. The development team had redesigned the user interface four times because of differences of opinion among management. Nokia realised too late that Symbian had reached the end of the road and that the replacement was not ready. Apple, on the other hand, had a visionary at the helm. 'It is crystal clear from Steve Jobs' biography [Isaacson 2011] that no one was allowed to stand in the way', continued Ormala. 'Everyone worked towards the same goal. Nokia didn't have this.'

It is understandable that products and services have a natural life cycle. In The Reinventors (2012), management consultant Jason Jennings explores company progress from the introduction of a product to the advance towards market maturity, and then to the inevitable decline. If management has done its work properly, the remnants of sales are replaced by new products and services and a new cycle begins. There is a need to explore new paths to growth and profitability while exploiting and maximising the benefits of existing business operations. This management paradox is also called ambidexterity (Andriopoulos \& Lewis 2009; Gibson \& Birkinshaw 2004; He \& Wong 2004; Raisch \& Birkinshaw 2008). An analogy of everyday life ambidexterity would be having two properties: the old house is on fire and needs to be saved, while the new one is still under construction.

Continuing with analogies, Nokia had fallen victim to the 'Red Queen' effect made popular in management research by Barnett and Hansen (1996). The term refers to the Red Queen in Lewis Carroll's classic novel, Through the Looking Glass (1917), who had to run faster and faster just to stay in the same place. Many 
employees at Nokia felt the same (Doz \& Wilson 2017). Productivity gains and decreasing costs were consumed by price erosion and hyper competition (Banker et al. 2012) and the Red Queen competition was focused on device improvements, cost reduction and imitation (Giachetti, Lampel \& Pira 2017). Nokia had fallen into a 'competency trap', trying to win with old technology, while newcomers such as Samsung with the help of Google's Android and Apple caught up (Giachetti \& Marchi 2017). Nokia had been able to overtake Motorola in the 1990s, but now it was the Finnish company that would be disrupted (He, Lim \& Wong 2006).

Everyone understands this in theory, but in practice, it is difficult to abandon products and services that are still profitable. The most commonly used example is Kodak. Its own engineers warned that digital cameras were replacing film. Although Kodak owned important patents for digital photography, it clung on to film manufacturing, which was extremely profitable, until it was too late. In the same manner, Nokia did not manage its 'Kodak moment' (Munir \& Phillips 2005).

In 2008, it became evident that the top guard at Nokia felt no real sense of urgency: management was suffering from illusions of invincibility, reinforced by every crisis the company had survived. If this feels like too much psychology, it is worth remembering that management was facing an entirely new situation in which it needed to question its previous solutions. This was not a matter of production logic nor of handset styling. A completely new business model was required.

Nokia was up against the innovator's dilemma as described by Clayton Christensen (1997). To keep up with change, company management needs to exploit every opportunity, including cannibalising its existing business operations-paradoxically to remain alive by committing suicide. Christensen's fundamental view is that, when markets are large, the company that dominates one stage of development will rarely dominate the next. The things that contributed to past success will prevent it from recognising what is happening. Even customers, Christensen says, will be unable to lead the company into the new world. It did not help that The Innovator's Dilemma was required reading at Nokia. 



\section{Symbian Crashes}

When we discuss stakeholders, there was a very specific group at Nokia that had invested their whole careers in software development and their professional reputation and identity were at stake. These were thousands of engineers working on the oncedominating operating system for mobile phones, Symbian. Over the years, Nokia invested more in R\&D than most other corporations. In 1996, it had 8,000 employees-one in every four-working in R\&D. By 2008, it had 8,000 people working on smartphone software alone. Yet, Nokia's operating system, Symbian, was one of its great weaknesses.

More recently, in 2020, when Google's Android and Apple's iOS form a duopoly for smartphones, it is easy to forget that Symbian was the undisputed leader of first-generation operating systems until the last quarter of 2010. Nokia, Ericsson and Motorola had founded the Symbian consortium in 1998, based on the work by British company Psion. In 1999, Matsushita, owner of the Panasonic brand, joined the consortium, followed by Siemens in 2002 and Samsung in 2003. Europe was the brightest star among mobile phones and the place where standards were created.

For mobile devices, Symbian was the standard, like Microsoft Windows in computers. From 2000 to 2010, Symbian was used by the world's largest handset producers. The purpose of the Symbian consortium, led by Nokia, was to prevent Microsoft's operating system, Windows $\mathrm{CE}$, from dominating the mobile 
world and it was successful beyond expectations. As late as 2010, Symbian's market share was over 60 per cent. Within a few years, however, Symbian had completely disappeared. In summer 2016, Android's market share was 84 per cent and Apple's iOS was 14 per cent. Windows Phone was in with the other 2 to 3 per cent. Nokia had said goodbye to Symbian at the end of 2012, the last consortium member to do so. Symbian had fragmented into a patchwork quilt and was ultimately unworkable. The architecture had needed a complete rewrite for years, but that would have cost too much. Instead, the owners concentrated on improving the interface. Sticking with Symbian is often seen as the main reason for Nokia's defeat by Apple and Google (Doz \& Wilson 2017). Management also lacked the extensive technological capabilities needed to implement any of the alternatives Maemo (MeeGo), Android or Meltemi (Lamberg et al. 2019).

In the 1990s, Nokia had also developed two Symbian system versions of its own, S30 and S40. It used S40 in simple handset models from 1999 to 2012. The system versions ran on 2 billion lower-price devices and laid the basis for Nokia's incredible success in the 2000s. These phones provided 90 per cent of Nokia's revenue and 20 per cent of its profits. However, to run smartphones that could access the internet and run applications, Nokia needed a more advanced system, built on Symbian; meanwhile, Symbian was facing an increasing number of problems.

What happened? Why did Finnish and European programmers lose the battle to Silicon Valley, where Google's and Apple's operating systems were developed?

Nokia started development work on a new Symbian-based platform, S60, at the end of the 1990s. Nokia management kept it secret from its Symbian partners because they had realised that ultimately the interface was the most valuable part of the handset. The project was codenamed 'Avery', after the tallest and clumsiest of the Dalton Brothers in the Lucky Luke comic book series.

Symbian was known to be difficult to code, which created business opportunities for the consortia who could sell consulting service with licences. 'Implementing the S60 was incredibly complex 
and difficult', Christian Lindholm, a director at Nokia User Interfaces from 1995 to 2004, said in his interview. 'It took vastly more time and resources than we expected. Instead of two years and 200 employees we needed five years and 500', he continued. The first implementation of the S60 came in 2002, with the Nokia 7650, a camera and phone that could also access the internet. The same year, the 7650 appeared on the cover of The Economist magazine. The headline was 'Computing's New Shape' (The Economist 2002), and the article inside the magazine announced how Nokia's new phone would affect the fate of humanity by changing the way data is processed.

This was the final proof to Lindholm that his team had done something significant. 'At approximately the same time, things started to go wrong, he says. Nokia was far from alone with its interface problems. Ericsson had already failed in an effort to change platforms and Motorola had similar difficulties with UIQ, the Symbian-based platform jointly developed by the two companies. Nokia's S60 was still a success at this point.

'Software was the reason that handset manufacturers died off, one at a time', Lindholm states. In each company, there was only a small elite team of 10 to 15 people capable of managing the programme architecture, and they were constantly being called away to fight fires, that is, to deal with urgent software problems. 'The simple fact is that there are big differences between programmers, as there are between athletes. The programming elite were needed everywhere, Lindholm continues. According to Lindholm, problems began to build up when Nokia began to develop GPRS.

Symbian is said to have been one of the biggest software development projects in history. It contained 40 million lines of code. By 2007, the development team contained more than 60 people who could call themselves chief architects in some area of the operating system. It was like a restaurant kitchen with 60 head chefs. By comparison, Android was created with two or three people in charge.

By the time insiders realised the problems associated with Symbian, in 2006, Ollila was moving to the position of Chairman 
and President of Nokia. In his memoirs, Ollila claims that senior management was not informed that there was anything wrong with Symbian. Ollila places the blame for its failure on software engineers (Ollila \& Saukkomaa 2016).

Veli-Pekka Saarnivaara, former head of Tekes, disagrees with Ollila. Saarnivaara says in his interview that the mistakes were made by management and how it utilised the skills available in the workforce. John Ankcorn, a software architect at Nokia until 2013, also sees Nokia's corporate culture as the main problem. In his interview, Ankcorn said that Nokia had excellent engineers, but 'they were treated like animals'.

Senior management did not understand programming and they excluded software engineers from talks about strategy, where they could have explained the possibilities available. Instead, they were asked to send their views in a PowerPoint proposal. 'No one can write down in advance what he will say in a meeting that he is not attending, Ankcorn points out in the interview.

Ankcorn studied Symbian in 2005, when Nokia wanted him to get involved in its development. 'The source code was so horrible that it is difficult to put into words', he states. There was no clarity of purpose that would have made it easy to develop applications.

Already in the mid-1990s, Nokia's management knew that the switch from a hardware world to a software world of platforms would be inevitable. Søren Jenry Petersen, a Danish manager at Nokia from 1994 to 2011, notes in his interview that this became a huge problem:

When you are the number one in the world and you have 17,000-19,000 engineers whose entire career, the entire management structure, everybody's promotion for 10, 15, 20 years has come out of a hardware world, you're not very liable to have meetings and sit down and agree that, okay, we are all not useful anymore and now we need software people.

Telling the top management that they lacked competence in software was not taken positively. Petersen shares an anecdote from some time around 2009-2010, when 50 of Nokia's top managers 
closest to Olli-Pekka Kallasvuo had gathered for a senior meeting and one of the managers, a senior vice president (SVP), went right to the core of Nokia's problem.

One of the top SVPs [Sebastian Nyström] on the software side raised the issue that one of the problems we have in the company is [that] our senior leadership does not understand the business. That brought the room to a quiet state, he [Nyström] said, 'Well, here's the thing. If I look at Microsoft, if I look at Sun Microsystems, if I look at Google, if I look at Apple, if I look at Facebook, all of the senior leaders including actually the CEOs, they can write code. They understand software.' Then he [Nyström] asked in the room, 'How many in here can actually write and correct code?' Very, very, very few people.

Sebastian Nyström had worked in technology at Nokia since he arrived from McKinsey in 2003. In response, Nyström was criticised by the management for bringing up issues regarding the leadership's core capabilities and competences, which was not the topic now on the table. However, everybody left with the feeling that this lack of core competences was not to be discussed, according to Petersen.

It was not only about Nokia. The Symbian software was becoming a problem for Europe as a whole. European programmers were no less talented than their US colleagues, but they lacked long experience with systems architecture or major projects involving the internet. Symbian was not developed to be an operating system for internet phones and web browsers were not considered a core feature (Ocock 2010). Over the years, the problem with adding new features such as multimedia applications became increasingly difficult. At Symbian, project leaders were also faced with a gaping technical debt, meaning the accumulated cost of extra work caused by earlier quick fixes for programming problems where durable solutions would have taken too long (Kruchten, Nord \& Ozkaya 2012).

In 2004-2005, Nokia was already planning to buy Ericsson and Motorola out of the Symbian consortium in order to take 
complete control. The deal did not go ahead until 2008, and by then, the problems of Symbian were widely known. Nokia's appeals to other handset manufacturers to help it convert Symbian into an open code project fell on deaf ears. If it had managed to acquire Symbian a couple of years earlier, the open source project might have succeeded with the aid of the best programmers and architects. Now, it was too late.

Applications and content had become the main way of creating user experience. The operating system and the user interface were merely part of an ecosystem of services and applications. Nokia management believed for too long that everything still revolved around devices when, in fact, everything revolved around the internet. A mobile device was just one way to get there. 'Americans understood this because they had invented the internet. This is why the focus of mobile telephony shifted to the US', says former Nokia manager Martin Sandelin in his interview.

Petra Söderling, the Nokia software manager, confirms in her interview that the development roadmap focused entirely on devices. 'Nokia pored over component delivery times. They were used to decide what devices would be offered, for example for the Christmas season. It was the wrong way round.'

All operating systems-Android, Linux and iOS-have version roadmaps that lay down future updates in precise detail. At Nokia, the devices were planned first. They were developed as separate projects and the project leader then announced what extra functions each model should have. Development parameters were set by devices.

Former Nokia Head of Information Management and President at Sitra, Mikko Kosonen, also paints a picture of a productoriented organisation where strong product leaders competed. 'Moreover, the incentive system rewarded people who achieved the profit and sales objectives of the next quarter. They did not see the core of the problem, which was the platform', Kosonen says in his interview. Instead of concentrating their efforts on standardising and harmonising Symbian, Nokia management was constantly disrupting it with new products that required different features. Each model needed its own version of the software. By 
the end of the 2000s, there were as many as 57 versions of Symbian (Doz \& Wilson 2017).

Risto Siilasmaa, who stepped down as Chairman of the board of directors in May 2020, already had personal experience of serving Nokia in 2001, when his company F-secure developed security software protecting Nokia S60 phones from viruses. The first virus appeared years later, in 2004. 'It was not like you had to develop software for each model, sometimes you had to develop different versions of software for the same phone', Siilasmaa says in his interview.

For external developers of applications, the demands of Symbian were a nightmare. Even a single change in the size of the screen required all applications to be updated. Applications that worked in the third version of $\mathrm{S} 60$ would not work in the first and second versions, and vice versa. The last version of S60 was released in 2008, and in that the touchscreen did not work. Söderling points out that operating systems need continuity. 'Apple and Google are extremely cautious about changing anything that will require application updates', he says.

In the summer of 2011, Nokia outsourced development of Symbian to Accenture, a global professional services company, and 2,800 people in the United States, Great Britain, China and Finland had a new employer. The plan was to keep Symbian alive until 2016, when Windows Phone would take over as the only operating system for Nokia smartphones. However, after February 2011, when Nokia CEO Stephen Elop told the employees that the company was 'standing on a burning platform', interest in Symbian came to an abrupt halt (Nykänen \& Salminen 2014: 133-136). Some accused Nokia of outsourcing layoffs to Accenture. Although hundreds of former Nokia employees worked for Accenture on Windows and other technologies for a long period after this turning point, Symbian's tale ended dishonourably.

\section{Life Blog}

Looking back at Nokia's history for the past 20 years, one can see a long line of failed attempts to design the future of digital communication. Nokia launched its own mobile portal Club Nokia for 
different services and applications in 1997, which was a gateway to customer support, special offers, games, customised picture sharing, tools for composing ringtones and other features (Doz \& Wilson 2017). Soon, the portal met strong opposition from the telecom operators which were Nokia's main customers. They objected to Nokia's attempt to create a stronger relationship with its end customers.

UK-based Vodaphone even ordered an alternative service portal, Vodaphone Live, from Satama Interactive, a subsidiary of a Finnish publishing company.

Christian Lindholm, working at Nokia User Interfaces in 2000, was sent to Vodaphone to explain Nokia's intentions, but soon realised the futility of telling a customer that you want to compete with him. When Lindholm returned, he proposed to Nokia's management that the company should start managing data and rights for all phone users, as Apple and later Google did. 'We should have taken over user address books, contact information, photographs and messages. I went back to the lab and constructed the Lifeblog service, Lindholm says in his interview. It was the first mobile application to put different types of media on a timeline, which could be transferred to a computer. 'It was great fun to implement and fantastic now when people ask if I realise that I invented Facebook, although that's an exaggeration', Lindholm continues.

After a dramatic boycott by operators in 2003 and intense negotiations the following spring, Nokia decided to close Club Nokia in 2004. An interview with Lindholm in The Guardian newspaper in 2004 is another sign that Nokia had experts who were well ahead of Apple. In the article, Lindholm said that the mobile phone was becoming a device for managing personal content (McIntosh 2004). Nokia management was not impressed. 'In very many matters it was extremely hard to make any progress. I remember thinking that this will not end well. I was very interested in the mobile internet at the time so I decided to leave the company in 2005', Lindholm concludes.

In mobile telephony, Nokia invented the wheel. Then Apple added decent tyres. However, Club Nokia was not the last attempt to connect end-users more closely. Nokia had a music service 
'Comes With Music', an internet service brand 'Ovi', a games console, extraordinarily good cameras and excellent sound reproduction. However, it failed to put them together into an attractive, user-friendly package. Even the technically minded found it hard to use Ovi, whereas a child could quickly grasp how iTunes worked.

\section{Touch Screens}

The Palm Pilot, an early US hand-held computer (Personal Digital Assistant, or PDA) was first unveiled in 1996. Christian Lindholm saw its potential for smartphones. 'I began to argue that it ought to be possible to use a mobile phone with one hand and I was told to work out what it would mean in practice, Lindholm says in his interview. 'PDAs were not designed to be controlled by your fingers, because a pen or a stylus can click on far smaller objects. This allowed the designers to put a great number of objects on the screen, creating an absolute mess. I didn't like it at all', he continues. When Steve Jobs showed off the iPhone ten years later, Jobs proudly announced that it could be used with one hand. Lindholms's vision was vindicated.

Nokia's first touchscreen phone, the Symbian-based 7710, was introduced in 2004, but it flopped. It seemed as if consumers wanted to keep the keyboard. At the end of 2008, Nokia announced the N97, intended to beat the iPhone, again with a touchscreen and again with a user interface based on clumsy Symbian.

Nevertheless, these were not the world's first touchscreen smartphones. In 2000, Ericsson of Sweden had unveiled the touchscreen R380, also the first smartphone to use Symbian. Ericsson tried in vain to entice Nokia into a joint project to develop touchscreens. In an interview by Karlsson and Lugn (2009), Ericsson's Chief Technology Officer Jan Uddenfeldt said it was now too late, because of Apple's leadership.

Sadly enough, Sony Ericsson had developed touchscreens many years earlier but abandoned them because of a lack of customer interest. Sony Ericsson was ahead of its time. It really is a 
great pity that Nokia never realised what it had missed. All the time, they stubbornly rejected touchscreens. If they had joined the race things would have been different. (Karlsson \& Lugn 2009: 246)

\section{WiFi}

In Europe and the United States, almost half of wireless data traffic is via local area networks, attracted by their low cost and great capacity. Downloading large volumes of data from a mobile phone network is expensive and difficult. The United States, in particular, is mobile paradise for operators rather than consumers. In the developing world too, in countries like India, many people own smartphones, but cannot afford mobile data. Instead, they use WiFi and other wireless local area networks (WLANs).

What has been difficult to create is a revenue model. Use of networks is usually free, and the providers-cafes, restaurants, shops, etc.- do so in the hope that it will bring new customers and support from advertisers, content producers and others. WiFi also functions as a good navigational aid. Satellite-based GPS provides a less accurate reading of where the phone user is. Nokia reconsidered its attitude to WiFi several times. When a triumphant and confident Jorma Ollila presented the company's report in 1996, the emphasis was on internet-based technology and the Communicator 9000 handset with internet connectivity (Nokia 1996). Phones would shift seamlessly between mobile phone networks and WiFi base stations. The plan would have put Nokia five years ahead of its competitors.

At the end of the 1990s, Nokia established a technology centre in Silicon Valley, aimed at keeping the company in the internet's inner circle. In 1999, a new division, Nokia Internet Communications, was established in Mountain View, California, with 1,400 employees. But Nokia headquarters changed its mind. It feared the anger of mobile phone operators, who would lose traditional revenue flows from phone calls to VOIP (Voice over Internet Protocol), voice calls made over the internet. 
One example of Nokia centre dealings in Mountain View is Vienna Systems, a VOIP company established by Kent Elliot, which had been acquired by Nokia in 1998. Within 4 to 5 years, Elliot left Nokia, as did several other VOIP project leaders. The official reasons Nokia gave for rejecting the new technology were that it was immature and unreliable according to people interviewed. Together with Elliot worked people like Mika Vehviläinen, later CEO of Finnair, and Pekka Lundmark, who after a successful career as a CEO ended up as the top manager at Nokia in 2020. Lundmark and Reijo Paananen, the inventor of the Nokia Communicator 9000, were implementing the WiFi strategy and had closed several contracts with US operators. However, Nokia's management decided to end the collaboration and both Lundmark and Paananen left the company in protest.

According to an interviewee, the only dissenting Nokia executive was J.-T. Bergqvist and he also gave up. A member of the Nokia inner circle at around 2000 told me: 'Bergqvist was the only one who believed in VOIP. The market did not, the operators did not, the customers did not and their partners did not'. However, to abandon it was a U-turn in Nokia's strategy.

The strategic turn did not come until 2004, when Nokia released its first telephone equipped with WiFi access, Nokia 9500. By now, competitors were also producing similar devices and it took another two years before Nokia trialled phones that switched data connections automatically between the mobile network and the wireless network.

After this, Nokia again reversed its strategy. Speaking in January 2007, at Las Vegas CES, the international consumer technology tradeshow produced by the Consumer Technology Association, Nokia CEO Kallasvuo said: 'Then, there is WiFi, which has truly become a universal mobile broadband technology'. Kallasvuo proclaimed that the keys to the mobile internet were wireless network technologies such as WiMAX. Nokia launched a WiMAXenabled tablet computer in 2008, but it was in production for only a year. WiMAX had too few users and Nokia still could not decide whether wireless broadband was a credible alternative to thirdand fourth-generation mobile telephony. 
Yrjö Neuvo, the Chief Technology Officer at Nokia from 1993 to 2006, still believes that Nokia would not have been the right home for WiFi equipment because mobile operators disliked the technology. Neuvo also says in his interview that Nokia did not invest enough in it to make successful products. 'You need to strike the right balance: operators were important customers and obviously they did not like VOIP. If Nokia had moved aggressively into internet calling, networks sales would have collapsed, Neuvo states.

Neuvo's former colleague, Erkki Ormala, also points out in his interview that operators preferred to update existing equipment rather than buying new technology. No profitable business model was found for $\mathrm{WiFi}$, although integrating it into mobile handsets was child's play according to him. Worrying about the welfare of operators was ultimately futile because they lost their fight against WiFi anyway. 


\section{Debacle in the United States}

In October 2014, Finland's Prime Minister Alexander Stubb suggested that Apple was to blame for the demise of Finland's two biggest industries, which in turn led to an economic downturn and a ratings downgrade for the Nordic country. Stubb's statement came just weeks after Microsoft had acquired Nokia's mobile phone business. 'We have two champions which went down', Stubb told the business news channel CNBC (Clinch 2014). As well as the technology firm Nokia, he explained that the paper industry in Finland had fallen on hard times. 'A little bit paradoxically I guess one could say that the iPhone killed Nokia and the iPad killed the Finnish paper industry, but we'll make a comeback.'

This was certainly an exaggeration as neither Nokia nor Finland's paper industry were going to die. And, with the acquisition of Alcatel-Lucent in 2015, Nokia again became the market leader in network technology in the United States. However, on the mobile device side, it disappeared from the market early.

Nokia was the world's largest handset manufacturer for 14 years, from 1998 when it overtook Motorola, until 2012, when Samsung became number one. Nokia's decline began in the United States, so it is worth examining the chain of failures there, resulting from gross strategic errors, arrogance and the clash of corporate cultures.

Nokia's conquest of the United States began back in the 1980s, when it was manufacturing mobile phones with a US company, Tandy, and selling them under the Tandy brand at more than 
6,000 RadioShack stores around the country. Motorola did its best to halt the Finnish invasion with trade barriers and copyright disputes, but Nokia gradually gained a foothold for its brand.

Awareness of the Nokia name widened greatly when the company obtained a listing on the New York Stock Exchange in 1994. By then, four of the country's five telephone operators were selling Nokia phones. The company was renowned for listening to its customers.

After 1994, Nokia's market capitalisation was set on the New York Stock Exchange. Successful operations in the United States and prominence in the country were important to the share price. When Martin Sandelin was sent to the States in the mid-1990s to manage Nokia investor relations, he went to Texas because Nokia's US head office was close to RadioShack's in Irving, Texas. Irving is one of the many suburbs of the Dallas-Fort Worth metropolitan area. It is known as Silicon Prairie, home to electronics, telecommunications and defence industry companies.

Texas Instruments was also in the area, which later became an important partner for Nokia. For a long period of time, Nokia was a success in Texas. Its slogan Connecting People even gave the name to a street in Irving, 'Connection Drive.' The company invested billions of dollars in US visibility, principally in sports events.

Nokia climbed rapidly, reaching a 44 per cent share of the US market by the end of the 1990s. It then steadily began to weaken, but in 2004, it still had the hottest telephones and 30 per cent of the market. Motorola had to content itself with second position at 20 per cent. In 2006, however, Motorola was at 33 per cent and Nokia had only 15 per cent left. What happened in those two years?

There are many explanations for the collapse. One was the clamshell, or flip phone, a trump card held by Motorola that Nokia did not want to copy. Motorola's flip model, the Razr, was the talk of 2004. More folding models were unveiled later, but the clamshell proved to be a passing fashion. Nokia had expected this and, after the fashion had passed, it won back some of its market share. But, in the wake of its success, it was becoming arrogant and no longer paying attention to its most important US customers, the mobile phone operators. 
'It was extremely hard for Nokia to customise telephones for individual operators', Martin Sandelin says in his interview. 'It didn't even try, so the operators turned to other manufacturers', he explains. Nokia could have made custom-made models, but its business was based on exploiting its unique production and distribution machinery as efficiently as possible. It was not optimised for small series.

Nokia also ignored the rules that underpinned the dominant position of US operators. In the United States, telephones were provided to users almost free of charge, after which the operator clawed back the money with long contract periods, generally two years. There were two main phone price categories: US\$99 and US\$109 dollars. Manufacturers had to accept these. It was not until 2016 that the operators abandoned this sales system.

There are two basic mobile telephony standards in the United States: GSM and CDMA. Operators Sprint, Verizon and US Cellular use CDMA, while AT\&T and T-Mobile use GSM. Most of the rest of the world uses GSM. Although Nokia was a great power in GSM, it had not achieved the same position in CDMA phones. Its product development unit in San Diego realised that Nokia needed to change its strategy and begin developing chips in collaboration with its archenemy Qualcomm, which was the dominant force in CDMA technology. However, a protracted patent dispute between Nokia and Qualcomm destroyed this possibility.

It was not only the flip phone that Nokia refused to make. Its management did not listen to consumer requests for a qwerty keyboard like on computers or touchscreens. It could not even tell operators when Nokia phones would start using HSDPA (High Speed Downlink Packet Access), a technology that increased the speed of data transfer. Nokia constantly broke promises to operators, for instance, regarding product delivery schedules, because the United States did not have a special position in its product development. Inside Nokia, the United States was also considered a backward country in terms of mobile communication.

While Nokia broke promises, Samsung and LG, Korean handset manufacturers, did everything to please operators. Nokia was consistently 18 months behind. 'We offered models which we said 
we were selling in 10 other countries. The operators answered that they already had phones like that and didn't need them', a former Nokia employee in the United States recounted in his interview. He continued:

Samsung and LG had made the US market their main target. Their approach was to ask what the operators wanted. Initially their phones were no better than acceptable but gradually they became exceptional. The Koreans offered ten product categories and asked: Which do you want? Then they produced the one that was chosen and ditched the nine others.

Cultural differences may also have been to blame. Apart from Olli-Pekka Kallasvuo, no top Nokia executive was based in the United States. When Kallasvuo took over in 2006, he made it his mission to win back lost US market shares. Kallasvuo had been responsible for Nokia operations in the United States in 1997 to 1998, when sales had skyrocketed.

The opportunity soon presented itself. In 2007, Kallasvuo was asked to be a keynote speaker at the CES trade fair in Las Vegas. 'When Kallasvuo took a phone from his pocket and started expounding Nokia's vision of the consumer groups it would serve, I didn't know whether to laugh or cry', said Pekka Pärnänen in his interview. Pärnänen is a Finn working in Silicon Valley, formerly for Finpro, a trade development organisation at the time. Pärnänen continued:

He said he knew exactly what Americans thought because he had spent a lot of time in Manhattan. It was the last nail in his coffin. Mobile technology revolved around Silicon Valley and he was talking about New York. People looked at each other and wondered what planet he was from.

At the CES, Nokia presented its new multimedia telephone, the N93i, which had been shown in the Transformers movie and was a strange combination of a telephone and a video camera. The model supported a free blog service Vox, on which users could begin to 'share their lives in a genuine Web 2.0 way', as the phone's advertisement stated. 
During the event, Kallasvuo also announced that Nokia was bringing Skype to mobile phones. Its S40 platform models would offer Yahoo Go, a service for address book synchronisation, phone chat, automatic picture uploads and support for Yahoo Mail. Even inside Nokia, the deal was regarded as a joke because Yahoo's image as a flag bearer of the internet era had long since faded. The Vox blogging service did not last, either. It promised to be a way of obtaining an OpenID, an authentication protocol that could be used to establish your identity on other services. It later transpired that the identity disappeared when Vox did.

Unknown to Kallasvuo, Nokia's last opportunity to win back the US market was disintegrating. The following day, on 9 January 2007, some 700 kilometres away in San Francisco, Steve Jobs presented the first iPhone. It came to market in June of the same year, with sales handled by AT\&T, the same operator that was waiting impatiently for a Nokia phone based on 2.5G technology.

Nokia had started paying attention to the US markets, but, when it finally had a $2.5 \mathrm{G}$ telephone to offer, it discovered that AT\&T had an agreement with Apple-and for only a 2G phone. Nokia responded by trying to go it alone and began offering its phones via independent telephone distributors like the Best Buy consumer electronics chain. However, in 2008, the operators were buying a full 90 per cent of US mobile handsets, and independent distributors only a tiny proportion. The operators were also the main phone advertisers: in 2005 to 2006, they were spending US $\$ 2.3$ billion a year on marketing, while phone manufacturers were investing only US $\$ 150$ million.

The result was a catastrophe for Nokia. By 2008, its share of handsets sold in the United States had fallen from 24 to 8 per cent. Measured in US dollars, the drop was from 16 to 4 per cent. Nokia had become the supplier of cheap models and no one wanted to market its phones. In 2003, its revenues in the United States were nearly US $\$ 4$ billion: by 2008 , they had fallen by half, an enormous plunge.

It is noteworthy that, although the iPhone and Android are often given as the reasons for Nokia's failure, it began losing market share before they arrived. By the time Nokia management realised it had a problem in customer relations, it was too late because the 
iPhone and Android had appeared on the scene. Even the world's largest handset producer could not change the reality that, in the United States, it was the operator that decided which models would be sold. Steve Jobs' success was in persuading operators, in knowing what consumers wanted and getting AT\&T to back his vision.

Nokia management must have been able to see what was happening. Although Apple tried to keep its development work secret, patent applications would have revealed what was going on. Nokia management failed to join the transformation, led by Apple, in creating an ecosystem of services around its phones. Its famous scorn for Apple also blindsided it. Nokia had made an early start in mobile phone services, but could not exploit this because it had failed to modernise Symbian.

People at Nokia knew what was coming. In 2006, Nokia employees were asked to identify the 10 most probable threats to Nokia's well-being. Number one, according to Risto Siilasmaa, was something that resembled the imminent iPhone. 'These guys voted that the most probable thing would be an iPod with mobile phone functions', Siilasmaa says in his interview. Jorma Ollila tells a similar story. In the autumn of 2007, Ollila asked a dozen of his managers if the iPhone would become a tough competitor. Only two of them responded no because the Symbian operating system was so good. The rest saw Apple as a threat that could not be avoided. 'Some of them expressed their views in terms not fit for publication. The message was clear: most of Nokia's key people were alert enough to grasp that Apple already had thrown down the gauntlet in the contest for the smartphone market' (Ollila \& Saukkomaa 2013: 337).

Nokia management forbade the company's employees to use any other phone than Nokia, so they could not get a sense of what the iPhones or Android phones could offer in terms of usability and services. What they at least knew was that efforts to create an own ecosystem were a continuous source of headaches. Nokia did try to persuade US application developers to create services for Symbian. In the spring of 2007 , Nokia announced a competition 
for the world's largest developers called 'Mobile Rules', and the winners were flown in to Espoo to meet Nokia's leadership. By 2008, it was clear that Symbian lacked a clear roadmap that would have shown developers where it was heading. Developers left Nokia, moving to the Apple iOS platform and, soon after, to Android. Apple and Google were also constantly updating their operating systems, but incrementally, transparently and logically. 'Without developers there were no applications and without applications no one bought telephones', Pekka Pärnänen, who then worked with Nokia on the Mobile Rules competition, said in his interview.

Nokia had optimistically taken over several technology companies in the late 1990s and early 2000s to stay abreast of developments, but it is difficult to find any trace of its acquisitions in its innovations. Not one of the companies was the best in its field and the key staff left their new employer as soon as they could, because Nokia's processes were so slow and laborious.

Yrjö Neuvo, Chief Technology Officer at Nokia, retired before the company was starting to face alarming problems. In 2008, Nokia appointed a new Chief Technology Officer, Bob Iannucci, who had been running its research centre in Silicon Valley since 2004. Iannucci was the first member of the executive team to be based outside Finland. However, he did not stay in the job for more than a few months. Iannucci was succeeded by Rich Green, who also left the company shortly after joining.

The problems became acute when the release of Nokia's N97 handset, billed as the 'iPhone-killer', was delayed until summer 2009, and it was sold without operator support. Publicity went wrong from day one, its software was worthless and the model became a catastrophe (Doz \& Wilson 2017). Kallasvuo's attempt to win back a foothold in the US market were coming to nothing.

By 2011, Nokia had practically withdrawn from the US mobile phone market, which now counted for only 1 per cent of net sales. Instead, it concentrated its efforts on Europe and the rest of the world, ignoring the new reality that the United States was where new mobile services-applications-were being created, and applications were what determined a phone's success. Nokia 
Lumia handsets running the Windows Phone operating system were finally and expensively launched in the United States in January 2012, with marketing support from Microsoft, but it was too late. Consumers were no longer interested.

Nokia continued for too long to behave like a traditional electronics company. Its US head office should have been moved far earlier from Texas, the cradle of the electronics industry, to Silicon Valley, the home of the algorithm economy. When it finally moved from Texas in 2004, Nokia executives instead chose White Plains, New York. No one has been able to discern the business logic of the move. 'Moving the US office from Dallas to White Plains was the worst possible mistake', Pekka Pärnänen says in his interview. Pärnänen thinks the move was motivated by the desire to be able to fly comfortably in business class from different parts of the world directly to New York, and get to the office quickly. Finally, in 2011, Nokia US headquarters moved to Sunnydale in Silicon Valley, a 15-minute drive from the Googleplex.

Nokia's failure in the United States has also been linked to cultural differences. As an American, John Ankcorn says he sensed tensions between the Americans and the Finns for years. Recruitment in the United States generally failed because management picked unsuitable people. 'Finland has a culture of harmony, a desire to reach agreement. Management sought Americans who had the same conformity. They were the worst possible recruits because their friendliness disguised a lack of commitment', Ankcorn says in his interview. They were yes men who went along with whatever team and situation they faced.

Søren Jenry Petersen, head of Nokia's CDMA Business Unit in San Diego from 2001 to 2004, shares this view. Because Nokia's business in the United States was losing money, it could not find good enough people. 'If you are not making money you cannot attract top skills. You get B and C class employees', Petersen says in his interview.

Over the years, Nokia sent thousands of people to work at its offices in San Francisco, Mountain View, Palo Alto and Sunnydale, but not top-level executives. Kaj Häggman worked for Nokia 
in Silicon Valley, in various positions from 1996 to 2011, ultimately in developing internet products and integrating Silicon Valley units. Häggmann believes the main problem was that senior management was absent. In North America, there were only a few of Nokia's vice presidents, and Nokia had more than 500 vice presidents.

There was no one responsible for internet products and reporting to the CEO, able to tell him directly what was happening. The people here in Silicon Valley knew exactly what was going on, and how powerful Apple was becoming, but the messages reaching Finland were filtered, and the information changed, Häggmann says in his interview.

AnnaLee Saxenian, the dean of the School of Information and a professor in the Department of City and Regional Planning at UC Berkeley, is a renowned expert on Silicon Valley culture. In the book Regional advantage (1996), Saxenian gives Silicon Valley much of the framework and vocabulary by which the region now makes sense of itself. According to the interview with Saxenian, the mistakes Nokia made are common to many companies who want to learn from the region. Nokia staffed their office with local people, but the personnel could not get their messages on what was happening in Silicon Valley through to the headquarters in Espoo. The lack of communication was the number one reason why innovations wouldn't get accepted by headquarters.

'And number two, I'm not sure how well they integrated into the Silicon Valley networks. A lot of times, people come and set up these offices here, but ... it's just an open, empirical question whether or not they were really ... engaged', Saxenian says in her interview.

This confirms the view expressed earlier by John Ankcorn. Nokia's managers hired people who thought, talked and behaved like themselves and did not create tension-for instance, by criticising strategical choices.

With the benefit of hindsight, it is easy to grasp the big picture; Nokia was not pushed into the margins of mobile telephony 
by iPhone and Android, but by its own mistakes. On the other hand, with a more sensitive and communicative approach to what was going on in Silicon Valley, it might be that things had gone differently. And, there is also the other view, that Nokia decided to focus more on China than on Silicon Valley, which (time will tell) might have been a good decision. Some researchers believe that the technology industry in Shenzhen in South China is surpassing Silicon Valley (Nylander 2017). There has been a steady rise of technology stars in China and the country is determined to win the race in artificial intelligence (Kim 2018; Lee 2018; Tse 2015). And the development concerns data traffic as well: Chinese investments in 5G capability are the biggest in the world (Littmann et al. 2018). 5G enables the connection and interaction of billions of devices of almost any kind and collection of data from those devices. This will be the hyper-connectivity between people and things. 5G connectivity promises to lead consumers, industries and governments to new frontiers of productivity and innovation. According to the consultancy firm Deloitte (Littmann et al. 2018), since 2015, China has outspent the United States by approximately US $\$ 24$ billion in wireless communications infrastructure and built 350,000 new sites, while the United States has built fewer than 30,000. The consultants conclude: 'Looking forward, China's five-year economic plan specifies $\$ 400$ billion in $5 \mathrm{G}$-related investment. Consequently, China and other countries may be creating a $5 \mathrm{G}$ tsunami, making it near impossible to catch up' (Littmann et al. 2018: 1).

There are huge stakes in the race to the top of $5 \mathrm{G}$ technology. Another consultancy firm, HIS, predicts that in 2035, 5G is expected to enable US\$12.3 trillion of global economic output, with the United States and China reaping the majority of the benefits (Campbell et al. 2019). 


\section{Surrender to Microsoft}

When Nokia's Mobile Phone Division changed owners on 3 September 2013, many believed that Microsoft had been sold the Finnish crown jewels. In reality, Nokia's fate had been sealed nearly two years earlier.

It was at a press conference in London on 11 February 2011, where Nokia CEO Stephen Elop uttered the fateful words: 'The game has changed from a battle of devices to a war of ecosystems ... Nokia will adopt Windows Phone as our smartphone strategy'. Elop then invited his former boss and mentor, Steve Ballmer, onto the stage. The appearance of Microsoft's CEO completed the pandemonium.

In London, Plan B had become Plan A. The day before the press conference, Nokia's board had reached the dramatic decision to abandon its own operating system and adopt Windows Phone in its place. Nokia's original Plan A had been to develop viable new operating systems of its own: Symbian and MeeGo, plus Meltemi, a work in progress. The decision to abandon them and pass the job to Microsoft had dramatic consequences.

It was also a financial catastrophe, because sales of Symbian telephones suddenly collapsed. Nokia's board had destroyed business worth several billions of euros built up around Symbian, and replaced it with crumbs from Microsoft's floor. Of the added value of a mobile phone, the majority comes from software. Nokia was left with a tiny slice containing great financial risks, because the 
assembler is responsible for product recalls, guarantees, customer service and maintenance.

Even external observers, such as myself, saw that Nokia had lost control of its own fate. I was working as an opinion writer for the Finnish daily Hufvudstadsbladet at the time and wrote: 'The only hope is that the alliance with Microsoft is more than it appears, now that Nokia is becoming Microsoft's slave. In the worst scenario, the lights will go out at [Nokia's] product development units and the doors will close for the last time' (Lindén 2011). Nokia's decision wiped out half a billion euros of business $R \& D$ investments in Finland.

This turn of events also came as a shock to John Ankcorn, head of developing Nokia's Meltemi operating system. Meltemi was advanced enough to have been installed in 17 Nokia handset models, but it was now to be shut down. 'Nokia renounced its future. Why didn't it wait till its own product was ready?' Juha Ala-Mursula said in his interview. Ala-Mursula, a Nokia manager sitting in a meeting in Redmond, Washington, DC, says he saw from the expressions and body language of Microsoft executives that this was more than just the licensing of an operating system. Microsoft had gained control of Nokia mobile phones.

Finland's political leaders had been warned of the dramatic announcement by Jorma Ollila just before midnight on 10 February 2013. Just a few weeks earlier, Prime Minister Mari Kiviniemi had met Elop privately, and told the media afterwards that she was convinced that Nokia was on the threshold of an upturn (Ilta-Sanomat 2011). The government found it hard to decide what to make of the news. 'Nokia itself was not sure how the decision would affect Finland', said Petri Peltonen of the Ministry of Employment and the Economy in his interview. 'It made us realise that we had not understood the seriousness of the situation.'

Although the scale of the layoffs could not be foreseen, it was clear that there would be serious consequences in many places. By April 2013, the picture of destruction was starting to emerge. Thirteen R\&D units or factories around Finland would be closed. 
This would take the jobs of 18,000 employees. Another 2,300 developers would be moved to the payroll of a consultancy company, Accenture, to support Nokia customers during the transitional period. Nokia would invest $€ 50$ million in a so-called Bridge Programme to help people find new work in communities where Nokia had been a major employer.

How had Nokia ended up in this situation? When CEO Kallasvuo had been fired in autumn 2010, Chairman Jorma Ollila had been given - or had taken - the job of finding a new CEO, although Ollila had also been responsible for the selection of Kallasvuo. In his memoirs, Ollila looked for a technology leader from Silicon Valley, California. One name suggested was Scott McNealy (Cord 2014), the founder of Sun Microsystems, but McNealy later denied he was under consideration. Another name mentioned by Cord (2014) was Tim Cook of Apple, although one wonders why either of them would have been interested in moving to Finland. Instead, Ollila found Stephen Elop, a little-known Canadian who was familiar to the Nokia leadership because he had been a Microsoft negotiator when Nokia licensed the Office programme suite for Symbian telephones.

People who worked closely with Elop say they were convinced he would be able to change Nokia's corporate culture rapidly. Decision-making under Kallasvuo had ground to a halt. In his interview, John Ankcorn said the executive team resembled an inbred country club. Elop encouraged a free flow of ideas, not filtered through middle management. He was inspirational and known to be accessible around the clock. The atmosphere also improved among senior executives. Ankcorn said he saw two of the key managers, Niklas Savander and Kai Öistämö, talking together for the first time.

Nevertheless, one can also question the managerial efficiency of a CEO who answered employees' emails even at night. Elop was not a visionary, but a charismatic and charming missionary who got things done, a product person. He had studied computer engineering and management and had a long career in US software companies, which suited Nokia. 
Elop began changing Nokia's culture and values with a project named 'Challenger Mindset'. Nokia had to accept that it no longer ruled the world and was now up against Apple's iPhone and Google's Android. At the same time, the number of jobs in middle management was cut by half between 2011 and 2013. Elop brought the kind of transparency and accountability to Nokia that employees had not seen for many years. According to Risto Siilasmaa, on Elop's first day, he sent an email to every employee throughout Nokia-some 60,000 of them (Siilasmaa \& Fredman 2018). He sought their advice on how Nokia needed to change and what should be left as it was. More than 2,000 messages flooded in and everyone got a personal response from the new CEO. Based on this feedback and his background as a software engineer, Elop soon realised that Nokia had huge problems: the Symbian platform was in a sad state and the company could not compete with its Symbian devices.

Changing Nokia's direction was a demanding job, towards which Elop obviously worked very hard. This was a company plagued by bureaucracy and turf wars, where important concepts, such as agile and lean, were memories of the past. Some, seeking a scapegoat, have questioned whether Elop was competent, but he did what had to be done in a fairly hopeless situation. Although Nokia's sales continued to grow after he took over, Ollila and Kallasvuo had laid the foundations for calamity. The decline was certainly hastened by Elop's lack of personal vision, his 'Microsoft glasses' and his closeness to his former boss, Steve Ballmer of Microsoft.

When Elop took over in September 2010, the Nokia executive team discussed shifting to the Windows Phone operating system, but this was dismissed as verging on insanity, as Merina Salminen and Pekka Nykänen state in their book Operation Elop (2014). There were no guarantees that Windows Phone would fare any better against Apple and Google.

Nevertheless, within a month, negotiations started with Microsoft, where Elop and Ballmer discussed a change of strategy for Nokia. Nokia was also talking with the online search and advertising giant Google about using its Android operating system. According to Salminen and Nykänen, Google was ready to make major 
concessions, greater than Nokia management has subsequently implied. However, many key people at Nokia felt great personal antipathy towards a deal with Google.

The development of MeeGo was now seriously late, but its speed had improved and it was nearly ready to be installed in some Nokia phones. There was strong support for this option among Nokia executives, but there were also some dissenting opinions. Kai Öistämö, who had been responsible for MeeGo development for 18 months, had begun to lose faith in it. Elop's talks with major clients-telephone operators-have shown that they too had low expectations of MeeGo.

Negotiations with Google, a company described by some Nokia sources as arrogant, were broken off in January 2011. According to Risto Siilasmaa and Catherine Fredman (2018: 97), the message from Google was clear: 'They didn't need Nokia because they had already won the mobile phone race'. After that, talks with Microsoft moved to a conclusion. The Nokia executive team was formally unanimous in its support for a deal with Microsoft, but Nykänen and Salminen (2014) observe that some had doubts about the risks and problems that it would create. The Nokia executive team saw Windows Phone as an incomplete operating system and contaminated by the Windows brand. It was certainly true that Android was a winning ecosystem, unlike Windows Phone. The only person who thought the deal would hurt Nokia was an outsider, a McKinsey consultant.

A major reason why Elop and Öistämö favoured a deal with Microsoft was that Microsoft was willing to make a major investment in marketing and promised Nokia a special position in the future partnership. Less was said about the significant licence fees that Nokia would have to pay for using Windows Phone.

The strategy adopted by Elop and the board contained major risks and from some perspectives appeared foolish, but dissections of the consequences, in books as well as publications like the Wall Street Journal, All Things Digital and Businessweek, have been tainted with hindsight and personal trauma. The truth is somewhere in a mix of misunderstandings, falsehoods, myths and pure speculation. It will take time to construct a fair picture of this 
sensitive and crucial phase in Nokia's modern history, perhaps until the corporation's archives from the period are opened.

In any case, by the time the Nokia board met in London on 10 February 2011, there was nothing left to decide. It was already clear that the Windows Phone would become Nokia's new smartphone platform. After just three months of analysis and talks, the Nokia executive team and the board had made a U-turn in their strategy. At that time, Elop was not a board member, but it is easy to imagine that Windows Phone had been his favourite. He had learnt the mobile world at Microsoft and had accepted Microsoft's vision.

It is worth asking whether Ollila and the board understood that the decision opened the way to Microsoft's takeover of Nokia mobile phones. Analysts seemed to have understood the implications. 'Google and Microsoft are laughing all the way to a duopoly', 'This could kill Nokia', and 'Elop can expect Symbian phones to collapse by the third quarter' were some of the comments that rose to the news headlines. Nokia's share price dropped like a stone and was 12 per cent down the next day.

Risto Murto, then an investment manager of Varma insurance company, was astonished:

This was the largest strategic change that I have ever seen in a corporation. It was made in a hurry, the schedule was tight, and there was very little information available about what the new partnership would mean. Above all, it was hard to fathom the financial content. Large strategic changes generally take a long time.

For Tekes, which had been supporting Nokia's development work for three decades, the decision was disappointing for two reasons. The first was that consumers had already given the thumbs-down to Windows Phone, by not buying the Samsung, HTC, Dell and LG models that had been launched the previous year. Why had Nokia not begun to develop rival phones based on Android? Could it not have fought for a place alongside Samsung? 'It was also discouraging that Nokia's own development work had ended up in such a complete mess. It is difficult to grasp that such a large corporation 
could not cut it', said interviewee Kari Tilli, a Tekes manager who collaborated with the Nokia researchers for many years.

Elop's announcement was also a shock to Nokia sales staff, who were currently talking with operators about Christmas sales, the most important season by far. Suddenly, their customers learned that Nokia was stopping Symbian phones, but was unable to say when the first Windows phones would arrive. Unsurprisingly, no single operator wanted to order more Nokia phones.

Why did Elop destroy Symbian phone sales? Many questioned his loyalty to Nokia. 'Mr Nokia or Mr Microsoft?' Conspiracy theorists painted him as a Trojan horse sent by Steve Ballmer of Microsoft. Their reasoning went something like this. Elop and Ballmer agree that Elop will get Nokia to cancel Symbian, MeeGo and Meltemi, to make room for Windows Phone. When Nokia's share price collapses, it becomes cheap enough for Microsoft to buy Nokia Mobile Phones. Elop then receives handsome compensation and is made CEO of the new combined unit.

This speculation does not stand closer inspection. The mobile phone division was indeed sold to Microsoft in 2013 for US $\$ 7.9$ billion, but the negotiations were handled by Jorma Ollila's successor as Chairman of the Nokia board, Risto Siilasmaa. It is difficult to believe that an experienced Finnish business leader like Siilasmaa could have been so crudely deceived. If anyone was deceived, it was Microsoft, which paid an excessively high price. This view is supported by the fact that Steve Ballmer's successor at Microsoft, Satya Nadella, was anything but happy with the deal. Ultimately, in summer 2015, Microsoft had to write down the value of its acquisition by an astronomical US $\$ 7.6$ billion.

Stephen Elop spoke openly about his frustration over the sale to Microsoft because it meant that he had failed as the head of Nokia. As late as summer 2013, when rumours about a Microsoft bid began circulating, Elop told the Wall Street Journal that he saw no reason to sell mobile phones and that it was 'hard to understand its rationale' (Austin 2013). The only explanation for Elop's statement, in 2011, that Nokia was dropping Symbian in favour of Windows Phone seems to be that it was a mistake, a miscalculation. 
Nevertheless, there is one other example of similar action by another company. The Korean telecom giant Samsung has based its strategy on selling mobile phones with the operating system Android from Google. However, Samsung puts its own twist to Android and has also developed its own operating system, Tizen OS. One former manager in charge of developing new products, Kwan Min Lee, explains in his interview the logic of not being entirely dependent on Google's whims.

In the Nokia case you try to push your system and ignoring this open innovation outside. In Samsung's case, we use this open innovation outside ... while at the same time we do not kill our operating systems ... We have this kind of operating system just to build up our negotiation power.

Lee, who has a $\mathrm{PhD}$ from Stanford University and a background in Silicon Valley start-ups, is now a professor at Nanyang Technological University (NTU) in Singapore.

However, business research does indicate that an exceptional executive is usually fairly conservative and rarely makes radical changes (Collins 2001). When they are made, the changes are exactly planned and precisely implemented. Elop's announcement in London of the Windows Phone strategy does not fit this profile. Good business leaders are conservative because radical changes fail more often than they succeed. In a renowned article in 1995, Professor John P. Kotter of Harvard University laid out the steps that need to be followed for successful change. A single miscalculation means failure (Kotter 1995).

The first step, grasping the need for change, was something Elop succeeded in, and no one was left in any doubt about his view that something radical had to be done at Nokia. Elop succeeded in winning the support of Nokia's executives and even its employees. He also created a powerful vision of a new organisation combining Windows Phone and Nokia. He communicated this clearly and sufficiently often and, in a fairly short period of time, just eight months after the London announcement, he was able to present the first Windows phone in autumn 2011. 
Nevertheless, it was an error, a miscalculation, to unnecessarily destroy sales of Symbian telephones, which Nokia needed during the transition period. Another mistake was to speak too soon of Nokia's success, when nothing concrete had yet occurred. Resistance within Nokia to the new strategy gradually increased, as the chances of its success began to appear smaller than expected. Finally, it was realised that Microsoft was not the knight in shining armour coming to the rescue that had been promised: its software was defective and Nokia did not receive special treatment in solving its problems.

However, Microsoft was not the trusted partner hoped for by Nokia's management. Only a few months later, Microsoft acquired Skype, a service provider cursed by mobile telecom operators since it provided consumers with free phone calls. In June 2012, Microsoft shocked its industrial partners with the announcement it was launching the Surface tablet, which was obviously a first step on the way to its own mobile phones. Meanwhile, there were serious issues with Windows phones. Still, Stephen Elop was unable to tolerate criticism of Microsoft or Windows Phone, even as its ecosystem failed to grow as planned. Nokia employees, on the other hand, became increasingly critical and ultimately he had to employ security guards when visiting Nokia premises in Oulu and even head office in Espoo.

The problems facing the new Nokia Mobile Phones became obvious when it was acquired by Microsoft in autumn 2013. Soon after, when Stephen Ballmer was forced to resign early from Microsoft, the news spread that the Microsoft board had been against the takeover of Nokia Phones. Nevertheless, its new CEO Satya Nadella made his first foreign trip to Finland. 'Everyone began to realise that we were no longer working at head office but at Microsoft's Siberian branch', said one former Nokia employee in their interview.

At the time of the takeover, Microsoft had a strong reason to want Nokia. It was thought that speculators in China and South Korea would want to buy the whole of Nokia, apparently to obtain its patents and experts and to discard the rest of the company. 
This would have been detrimental for Microsoft because Nokia was an important partner and user of the Windows Phone system. There were other potential buyers too. A former Nokia executive, Thomas Zilliacus, had put together a consortium of investors in 2012, but his partners thought that Nokia was too expensive at the time and decided to wait for the share price to fall. 'I remember them theorising that the right price was no more than a couple of billion but instead the share price began to climb', Zilliacus said in his interview.

During his three years as Chief Executive, Stephen Elop, according to some interviewees, took his place in history as one of the worst ever leaders of a major corporation. A US brand consultant, Tomi H. Ahonen, coined the term the 'Elop Effect' to describe the rapid destruction of corporate value by a top executive (Ahonen 2013). Elop lowered the market capitalisation of Nokia by an average $€ 18$ million every day that he was Nokia's CEO, including weekends and holidays (Nykänen \& Salminen 2014).

By autumn 2013, the story of Nokia mobile phones began to approach its logical conclusion, although the media still treated the sale to Microsoft as a surprise. 'Nokia bombshell' was the headline of the evening's main television news bulletin by the Finnish Broadcasting Company, YLE. In the television report, Microsoft's CEO Stephen Ballmer promised that operations in Finland would not be closed or moved to Redmond, Washington, DC, and Nokia's Chairman and temporary CEO Risto Siilasmaa pointed out that Nokia still had its network business and its positioning technology left. Later, the board added a third remaining cornerstone to the list: its patent portfolio. But in Oulu, where 550 people were developing software for basic Nokia handsets, there was great unrest.

In an interview for public broadcasting news, Markku Kuisma, Professor of Finnish and Nordic History at the University of Helsinki, was asked rather strangely whether part of Finland's national identity was disappearing. Kuisma replied: 'Perhaps that happened already during the long-running crisis of the company. Nokia was the symbol of Finland's economic rise, and was very important when we were deep in recession in the 1990s. Then it represented recovery and opportunity' (Frilander 2013). 


\section{Another Future}

After years of building high expectations, 2019 became the year when the next generation of mobile communication, 5G, took off. This will be the main standard for wireless communication over the next 10 years until 6G, now in the early research stage, takes off some time in the 2030s. 5G is expected to provide new value as a basic technology supporting future industry and society, along with artificial intelligence and the Internet of Things (IoT). It will also provide further upgrading of the multimedia communication services with its technical features such as high speed, high capacity, low latency (the time required for a packet of data to complete a round trip between two points) and massive connectivity (NTT Docomo 2020). The mobile communication system has been evolving technically every decade, while the services of mobile communications have changed greatly in cycles of approximately 20 years. Thus, $5 \mathrm{G}$ and $6 \mathrm{G}$ will represent the third wave' in mobile communications. The 6G Wireless Summit 2020 would have kicked off in Levi in Finnish Lapland in March 2020, but due to the Covid-19 crisis, it moved online. Harish Viswanathan, Head of Radio Systems Research Group at Nokia Bell Labs, said $6 \mathrm{G}$ will 'unify the experience across physical, digital and biological worlds', while Dr Fang Min, Director of 6G Research \& Collaboration in the Chinese ZTE's Wireless Division, saw 6G 'integrating the physical and digital world' (Shi 2020). For 6G, Swedish Ericsson has already coined the expression 'Internet 
of Senses', pointing at the vastly increased interaction between human and intelligent machines with our brains as the interface: mind, smell, sight, taste, touch and sound will all be central to the experience (Ericsson 2019).

For Nokia's part, 5G success was mixed with disappointment and, in this chapter, a glance at the future is offered. In mid-2020, the road forward was not very clear as a new management team took over in the summer. Nokia had been unable to use its window of opportunity to overtake Chinese competitor Huawei. In the United States, Chinese suppliers have been banned from doing business over security concerns, which means that Nokia and Ericsson actually enjoy a de facto duopoly in the country. In addition, because the United States has no 5G technology of its own, there is even speculation that the government will acquire Ericsson or Nokia to compensate for that shortcoming (Milne 2020). The United States is also pressing other countries to take the same measures, but Huawei has already become a backbone in the mobile communication infrastructure in many EU countries.

Work has begun on a new strategy that will outline the future. There are so many unknown factors, both internal, which lay in the hands of Nokia, and external, which are dependent on the European Union's digital industry strategy, the trade war between the United States and China and other global development beyond the reach of a single Finnish company.

The new crisis at Nokia in 2019-2020 was the worst since the collapse of the mobile phone business. The profitability problems are reflected in the stock price, which had been down at $€ 1.42$ per share in the summer of 2012 and, after peaking in April 2015 at almost $€ 8$, declined again and got stuck in the $€ 3$ to $€ 5$ range. What sealed Suri's fate was a profit warning in October 2019 when the company's cash reserves were so low that the company had to terminate dividend payments to shareholders to be able to compete with Huawei and Ericsson for customers. Under Suri, the strategy was to broaden Nokia's portfolio so it could provide a full suite of products and services for operators who are building new networks (Rolander 2019). Nokia's 5G capital investment programme and roll-out to customers was eating up the cash flow 
at an alarming pace. As a reaction to the bad news, shares fell 26 per cent in Helsinki in the end of October 2019, which was the steepest decline since at least 1991, when financial news agency Bloomberg started collecting data on the company. In December, Nokia announced that Risto Siilasmaa would leave his position as Chairman of the board of directors in favour of another Nokia veteran, Sari Baldauf.

This was a new dramatic moment in the history of Nokia and will perhaps prove to be a new turning point.

Predicting the fate of global companies is not an easy task, as we have learnt so far in this book. In its 2019 Form 20-F filing (Nokia 2020) to the US Securities and Exchange Commission (SEC), Nokia presented a list of 31 risks and uncertainties that could change the company's direction (Form 20-F is submitted according to section 13 or 15(D) of the Securities Exchange Act of 1934). The five first mentioned, and therefore probably, most important, were: (1) strategic problems; (2) general economic and market conditions, including the timeline for the deployment of $5 \mathrm{G}$; (3) the threat from competition and the ability to bring profitable products, services, upgrades and technologies to market; (4) dependence on how the whole industry sector performs; and (5) dependence on a limited number of customers and extensive long contracts that can be affected by external events, such as industry consolidation. Looking back 10 years, we see that there have been some fundamental changes that were unforeseeable in 2010. The Nokia of 2020 was not the same company as it was 10 years earlier. Of the around 100,000 people working for Nokia in 2018, less than 1 per cent were employed by the company in 2012 (Siilasmaa \& Fredman 2018). However, Nokia has a way of renewing itself dramatically at intervals of roughly 25 years. When we look back on 2013 to 2020, we will perceive a period of transformation under the leadership of Risto Siilasmaa and Rajeev Suri. It will not have been as radical as the change wrought by Jorma Ollila and his team in 1992, nor as big as the merger of 1967, when modern Nokia was born from three companies. However, the 'doomsday pessimism' experienced in Finland about Nokia in the wake of the sale of its mobile phone division to Microsoft was excessive. 
Nokia has already served as both inspiration for companies struggling to reinvent themselves (Doz \& Kosonen 2008; Steinbock 2001; Steinbock 2010) and a warning example of failure (Lamberg et al. 2019; van Rooij 2015; Wang, Hedman \& Tuunainen 2016). Still, "'good" failures provide an opportunity to learn and should be embraced, leaving a set of "bad" failures that should be avoided' (van Rooij 2015: 204). One keen observer was the management at Korean company Samsung, which used Nokia as their main reference point when trying to enter in the mobile phone market around 2002 to 2003. The failure and revival is an inspiration that management frequently discusses, says Kwan Min Lee, previously a director of Samsung product development and now a professor in Singapore. 'We respect Nokia. Many people [at Samsung] worry that we might be the next Nokia. That's a constant worry that higher level management people always have. So what should we do ... not to be like Nokia?' Kwan Min Lee states in his interview.

Nokia also been presented as a warning example by others. For instance, in the end of January 2020, the CEO of Volkswagen Herbert Diess, warned that drastic measures had to be taken to accelerate the overhaul of its business to avoid becoming another Nokia (Taylor 2020).

It is easy to forget what a formidable consumer technology powerhouse Nokia once was. The company sold 250 million pieces of the cell phone model Nokia 1100 during the first five years after launch, which can be compared with 45 million units of the game system Nintendo Wii, 50 million Motorola RAZR phones, 125 million PlayStation 2 consoles or 174 million Apple iPods. Those numbers made Nokia 1100 the best-selling consumer electronics device in the world (Slywotzky \& Weber 2011).

Nevertheless, few would today claim that it was a mistake to leave the mobile phone business. Admittedly, Nokia's proud legacy was not handled with too much respect by Microsoft. Hopes that Lumia phones would become a major brand were dashed. The belief that a third mobile ecosystem would develop around Windows Phone was flawed for several reasons, the most important being that Android had become the industry standard and 
hard-core users of iPhone and other Apple products would never switch. Microsoft's promise that 'Finland will become the hub and the centre for our phone R\&D' was broken (Best 2013). Stephen Elop, who moved back from Nokia to Microsoft Devices Group in 2014, was fired in June 2015. A few weeks later, Microsoft announced that it was shedding 7,800 employees, 2,300 of them in Finland. In May 2016, it axed another 1,850 jobs, almost all of them in Finland. Out of its nearly 4,000 employees in Finland, Microsoft now had only a few hundred left in its local sales and marketing organisation. In Salo, the town that was the cradle of Finnish mobile telephony, as well as in Tampere and Oulu, Microsoft ceased all operations. The cuts were catastrophic for the country.

Nokia also changed direction in some problematic ways. Even Nokia's location mapping data service, HERE, was sold to a consortium of German vehicle manufacturers, BMW, Audi and Daimler, in 2015. Nokia provided its map data to 80 per cent of all car-navigation systems in the world and several major enterprises, including Amazon, Yahoo and Microsoft (Team 2015). HERE was sold despite of its strong 3D positioning technology, which was necessary for the industrial internet or IoT. 'Google had its platform and Apple too, but none of them came close to HERE, which had something unique', said one external observer in his interview.

However, from a 2020 perspective, mobile phones were just an intermediate phase in company history. Nokia's livelihood in 2020 comes from the development, manufacture and sale of mobile phone networks, a business created years before the arrival of Jorma Ollila. Nokia transitioned into digital technology back in the 1980s, when the CEO of Telenokia was Sakari Salminen. It brought the new technology to market in 1991, when the first GSM phone call was made from Helsinki to Tampere. All the while, profitable network business provided the economic resources to invest heavily in mobile phones, which later overshadowed everything else.

Networks kept Nokia's Mobile Phone division alive three times. The first was from 1985 until phones started selling well in the 1990s. Income from networks was needed again in 1994-1995, when phone production was in crisis. The third period was the 
summer months of 2013, before the phone division was sold. By 2020, Networks - their production, sales and maintenance-was Nokia's largest unit by far. Nokia Siemens Networks was created in 2007, in a merger between Siemens' networks business and Nokia Networks. In the summer of 2013, Nokia bought out their German partner Siemens' 50 per cent stake.

Facing extreme challenges, Risto Siilasmaa, as Chairman from 2012 to 2020, has brought Nokia through a radical transformation. These transformations include three of the largest business deals ever made in Finland-the sale of Nokia's core mobile phone business to Microsoft and the purchase of complete ownership of Nokia Siemens Networks (NSN) in 2013, and the acquisition of Alcatel-Lucent for $€ 15.6$ billion two years later. France's Alcatel and the United States' Lucent had gone through a messy 'merger of equals' in 2006, but everything went wrong and the management at Nokia saw a great opportunity on the way to passing Swedish Ericsson and becoming the world's largest mobile broadband company. Originally, Nokia planned on buying the mobile networks division for $\$ 2$ billion, but ended up acquiring the whole company for a price four times higher. This deal took Nokia from place number four in mobile networks to number two, before Swedish Ericsson, but after the global leader, Chinese Huawei.

External analysts have noted that the integration of two large companies, especially the IT systems, have taken its toll on management when it should have been focusing on 5G technology and not massive restructuring.

The innovative spirit of Nokia has not gone anywhere. The investments in $\mathrm{R} \& \mathrm{D}$ are as high as ever, around $€ 5$ billion a year, and Nokia is the leading company in Europe in terms of patents related to the fourth industrial revolution (4IR), according to the European Patent Office (Ménière, Rudyk \& Valdes 2017). In the whole world, only Samsung and LG from South Korea and Japanese Sony are positioned before Nokia. These are companies focusing on the hardware element and they account for 30 per cent of all innovation. According to the report from the European Patent Office, they have comparable patent portfolios, with leading positions in all core technology fields, and strong positions in 
several enabling technologies and application domains. The global importance of Nokia is highlighted in the report as the share of domestic innovations is only 35 per cent compared with 57 per cent for Swedish Ericsson.

Nokia's importance to the European technology future should not be underestimated. Nokia has for many years been one of the European companies with the highest spending in R\&D. In 2003, Nokia was placed number four after Daimler-Benz, Siemens and Volkswagen. That position changed into first place in 2007 with $€ 5.2$ billion in R\&D investments and, in 2009, the Finnish company was still number two after Volkswagen, but dropped to seventh place in 2012 and during 2016-2017 to eighth place. However, in the future, Nokia will be spending around $€ 5$ billion each year.

Technology companies are the world's most valuable, but US, South Korean and Chinese companies dominate. None of them is European, which means that the European Union lags behind the United States and Asia in many cutting-edge fields, such as the Internet of Things, the use of big data, artificial intelligence and 5G (Romei 2019). The new president of the European Commission, Ursula von der Leyen, who took office in December 2019, has put tackling the Union's loss of competitiveness in digitalisation at the top of her agenda. In the European Union, the Nordic countries are all at the top of digital performance, with Finland as number one (European Commission 2020), but there is no wide adoption of digital technologies in the largest member countries.

Moreover, it should be noted that although Nokia's investments in $\mathrm{R} \& \mathrm{D}$ are larger than Ericsson's, they are only around one-quarter of what Huawei invests in its technological future. As often pointed out, the competition is unfair as the Chinese company enjoys the state backing, which means huge subsidiaries. They allow Huawei to offer telco customers prices that are around 30 per cent lower than the competition.

The value of Nokia's great array of patents is difficult to assess. Intellectual property and licences have been converted into profitable licence agreements, but, in any case, the duration of patents is limited. Nokia's attitude to consumer products has been ambivalent. Although it licensed its name for use on phones from HMD 
Global, Nokia is apparently not returning to consumer markets and remains rooted in networks. This is a very different business from mobile phones. It can take years to lay the groundwork for a single network contract, but, when the operator has made its decision, the deal can be worth billions, and extends beyond equipment and software to maintenance, with updates for years to come.

With no consumer business, Nokia's need for marketing and hype has declined. When it was selling millions of telephones every day, it needed to have a visible and audible presence in the market. Now its customers-telecommunications operatorsnumber only a few hundred, and their demands are very different from those of consumers. The company is also more predictable and stable because it is under less pressure from the stock market. Nevertheless, there is still a sense of excitement and expectation. Billions of euros are being spent on developing the wireless networks of the future, but the results are not yet materialising.

In 2020, Nokia still influences the Finnish economy in many ways. Former Nokia employees have established hundreds of companies and many Finnish corporations or public organisations are led by men or women who learned their international business skills at Nokia. It is also a good thing that while Nokia's headquarters remain in Espoo, just outside the Finnish capital, its future is closely tied to Silicon Valley, where the intelligent machines and algorithms are developing at an accelerating pace.

In a period from 1995 to 2012, when Nokia was best known for mobile phones, it took Finland forward in education, research, product development, career opportunities, tax revenue and shareholder wealth, and also as a national brand.

What happens next with Nokia-and Finland? A complete management overhaul took place in 2020. In the spring, it was time for Risto Siilasmaa to step down as Chairman of the board and Rajeev Suri to leave after a quarter of a century as a Nokia employee; of these 10 years as the CEO of Nokia Networks and later the whole company, a period when the corporation went through a major transformation to focus on mobile networks. Siilasmaa's chosen 
successor was Sari Baldauf, one original member of Jorma Ollila's dream team, while Suri was replaced by Pekka Lundmark, who featured briefly earlier in this book. Lundmark had left the company in 2000 after yet another stop-go decision of Nokia management to disinvest in wireless technology. By then, he had been working for the company for 10 years, originally as Key Account Manager for the Finnish mobile operator Radiolinja, which connected the world's first GSM call. What goes around comes around: when he joined Nokia Cellular Systems at 26 years of age, his first boss was Sari Baldauf. Lundmark was later part of the Nokia Networks management team from 1997 onwards under Matti Alahuhta. He saw already in the mid-1990s that Nokia's main customers, mobile phone operators, had become an obstacle to business development. Lundmark's favourite book was and still is Christensen's famous analysis of failure, The Innovator's Dilemma (1997), which was also used internally for management training in Nokia. Christensen showed that when large technological transformation takes place, the leaders would often be replaced by new competitors: existing customers will be become a liability-in Nokia's case, during the switch from telecom to datacom and internet. It was still 10 years away from Google and Apple's disruptive technologies becoming the curse of Nokia (Vecchiato 2017).

Already around 1995, Pekka Lundmark had built up a personal interest for IP telephony and other wireless communication technologies, especially wireless LAN (WLAN). The following year, Lundmark collected his visions in a memo which was met with harsh criticism by management for not taking into account the interests of mobile operators. During his two years in Silicon Valley, Pekka Lundmark's vision was strengthened and he found a soul mate in Reijo Paananen, but when management pulled the plug on the platform for WLAN and IP telephony with services they were building, both men decided to leave. After 10 years at Nokia, Lundmark started a new successful career, first in 2000 as a venture capitalist together with former Ericsson CEO Christer Nilsson, later as CEO for several listed industry companies: design company Hackman (2002-2004), a lifting business with Konecranes 
(2005-2015) and energy with Fortum (2015-2020). He is also Chairman of the Confederation of Finnish Industries and is considered one of the most influential business people in Finland.

Sari Baldauf was chairperson of the board in Fortum when Lundmark was picked as CEO in 2015, and both of them now have the same positions in Nokia, chairperson and CEO. After his appointment as the new CEO of Nokia, the news agency Bloomberg noted that he was 'a long-term Baldauf ally' (Rolander 2020). In an interview in 2019, Lundmark admitted he was moving in familiar circles:

You have this classic saying that Finland is not a country, it is a club. However, that is also an advantage that most people know each other, we have a close relationship between business and the public sector, which you don't have at all in for instance Sweden. I actually think this is one of our country's strengths. (Olin 2019)

During the press conference where Lundmark's tenure was made public in March 2020, Risto Siilasmaa said on a personal note: 'We have left our impact on Nokia, but Nokia has left an even larger impact on us.'

Analysts anticipated a tight new strategy focused on cost savings and streamlining the business towards higher efficiency, as well as mergers and acquisitions: Lundmark was portrayed as a 'combative dealmaker' who would 'put the network equipment maker back in the race for $5 \mathrm{G}$ networks', and who was 'riding high after winning a long, politically-sensitive battle' for control of German energy company Uniper during his years in charge of Fortum.

'We expect Nokia to introduce large structural reforms and austerity measures under its new management in order to lay the foundations for a healthy long-term business', noted Mikael Rautanen, an analyst at Finnish brokerage Inderes (quoted in Rolander 2020).

The new strategy for Nokia will be influenced by development in Silicon Valley as a driver of industrial digitalisation. In 2018, Fortum under Lundmark launched a venture capital fund in Silicon Valley and rotates managers there to get a feel of the 
trends in the tech industry (Kurtti 2019). Konecranes under Lundmark moved its headquarters to China for two years to better understand the digital powerhouse. Lundmark knows the challenges in the manufacturing industry from the inside and has for many years focused on the power of industrial digitalisation and the IoT in his previous jobs. He will bring about a deep understanding of digital transformation in business and strategic thinking to Nokia. He is also well versed in political negotiations, which will come in handy when discussing the need to support and develop digital champions at the EU level, instead of the United States and China setting the rules of the global game (Milne 2020).

During the March 2020 press conference, Pekka Lundmark said in somewhat dramatic terms: 'The Nokia I left [in 2000] is not the Nokia of today, and it will certainly not be the Nokia of tomorrow.

Nokia would not be entering any very different business sector but will stay on the chosen path in mobile communications despite the risk that path dependence in different forms, technical, strategic and leadership, organisational and related to external collaboration (Wang, Hedman \& Tuunainen 2016), will limit the visibility of different options. For Finland, it means that the country will remain open and vulnerable to the global dynamics as before, but the years of dependence on Nokia and the aftermath show a high level of resilience in what was once known as the 'Kingdom of Nokia'. 



\section{Notes}

${ }^{1}$ Sitra, the Finnish Innovation Fund, is an independent public fund which, under the supervision of the Finnish Parliament, promotes the welfare of Finnish society. Sitra's aim is to promote stable and balanced development in Finland, the qualitative and quantitative growth of the economy and international competitiveness and cooperation. The annual budget is around $€ 40$ million (Sitra 2019).

${ }^{2}$ Tekes was founded in 1983 by the state to promote the development of industry and services by means of technology, innovations and growth funding. Research, development and innovation funding is targeted to projects that create the greatest benefits for the economy and society in the long term. Tekes does not derive financial profit from its activities, nor claim intellectual property rights.

${ }^{3}$ Solidium is a holding company wholly owned by the state of Finland and a minority owner in nationally important listed companies. Solidium's mission is to strengthen and stabilise Finnish ownership in the companies and to increase the value of its holdings in the long run.

4 The Centre Party of Finland is a centrist, liberal-conservative, agrarian political party in Finland. Founded in 1906 as the Agrarian League, the party supports decentralisation of political power from 
the capital Helsinki, and is the ruling party in the majority of Finnish municipalities.

${ }^{5}$ The quote is often used to describe the self-importance of businesses, but is in fact a distortion of what Wilson actually said, which was subtler. In 1953, when President Dwight D. Eisenhower appointed Wilson as Secretary of Defense, he was asked what would happen if he had to make a decision that was against the interests of General Motors. Michael Mayer (2009: 831) quotes him as replying that he could not conceive of such a situation 'because for years I thought what was good for the country was good for General Motors and vice versa'.

${ }^{6}$ The full, fascinating story can be read at http://www.storno.co.uk.

7 The Swedish People's Party of Finland is a political party that defends the interests of the Swedish-speaking minority in Finland.

${ }^{8}$ Laukamo provides contract manufacturing in electronics, sheet metal, injection moulding and liquid silicone rubber (https://www .laukamo.fi/en/company/), while Protopaja specialises in highprecision sheet metal design and production (http://protopaja.fi/en /about-us/). 


\section{Appendix A}

List of Interviewees

\begin{tabular}{|l|l|r|}
\hline \multicolumn{1}{|c|}{ Interviewee } & \multicolumn{1}{c|}{ Position(s) } & \multicolumn{1}{c|}{ Date } \\
\hline Aalto-Setälä, Pauli & $\begin{array}{l}\text { CEO, Aller Finland; former board } \\
\text { member, Elcoteq }\end{array}$ & 29.9 .2014 \\
\hline Ala-Mursula, Juha & $\begin{array}{l}\text { CEO, Business Oulu; former } \\
\text { manager, Nokia }\end{array}$ & $\begin{array}{r}19.8 .2014 ; \\
12.2 .2015\end{array}$ \\
\hline Alho, Arja & $\begin{array}{l}\text { Former Member of Parliament, } \\
\text { Social Democratic Party }\end{array}$ & 2.9 .2014 \\
\hline Ali-Yrkkö, Jyrki & $\begin{array}{l}\text { Research Director, Etla Economic } \\
\text { Research Institute }\end{array}$ & 1.2014 \\
\hline Alkio, Jyrki & $\begin{array}{l}\text { Former Chief Editor, Tekniikka \& } \\
\text { Talous magazine }\end{array}$ & 22.4 .2005 \\
\hline Andersson, Robert & $\begin{array}{l}\text { Former executive, Nokia; CEO, } \\
\text { Oriola }\end{array}$ & 18.8 .2014 \\
\hline Ankcorn, John & Former software architect, Nokia & 28.10 .2014 \\
\hline Arolainen, Teuvo & $\begin{array}{l}\text { Former journalist, Helsingin } \\
\text { Sanomat }\end{array}$ & 2015 \\
\hline
\end{tabular}

Contd. 
List of Interviewees (Continued)

\begin{tabular}{|c|c|c|}
\hline Interviewee & Position(s) & Date \\
\hline Baril, Jean-Francois & $\begin{array}{l}\text { Former Chief Purchasing Officer, } \\
\text { Nokia }\end{array}$ & $\begin{array}{r}28.5 .2014 \\
20.1 .2015 \\
21.2 .2018\end{array}$ \\
\hline Björklund, Otto & Former Head of Real Estate, Nokia & 6.2015 \\
\hline Blåfield, Antti & $\begin{array}{l}\text { Former editorial writer, Helsingin } \\
\text { Sanomat }\end{array}$ & 21.5.2015 \\
\hline Carlsson, Bengt & $\begin{array}{l}\text { Former journalist, Dagens Industri } \\
\text { newspaper }\end{array}$ & $\begin{array}{r}30.5 .2005 \\
21.11 .2007\end{array}$ \\
\hline Chipchase, Jan & Former employee, Nokia & 16.1.2015 \\
\hline Cronberg, Tarja & $\begin{array}{l}\text { Former Member of Parliament, } \\
\text { Green League }\end{array}$ & 11.2014 \\
\hline Fellman, Peter & $\begin{array}{l}\text { Chief Editor, Dagens Industri } \\
\text { newspaper }\end{array}$ & $\begin{array}{r}30.3 .2005 \\
27.11 .2007\end{array}$ \\
\hline Foulger, Josh & $\begin{array}{l}\text { Former Head of Manufacturing } \\
\text { Engineering, Nokia India }\end{array}$ & 8.1 .2015 \\
\hline Gideo & $\begin{array}{l}\text { Former Head of Communications, } \\
\text { Ericsson }\end{array}$ & $\begin{array}{r}4.2005 \\
11.2007\end{array}$ \\
\hline Hellström, Kurt & Former CEO, Ericsson & 5.2005 \\
\hline Häggman, Kaj & Former manager, Nokia & 12.11.2014 \\
\hline Kaivo-oja, Jari & Researcher, University of Turku & 2.2014 \\
\hline Ketonen, Timo & $\begin{array}{l}\text { Entrepreneur; former CEO, } \\
\text { Hansaprint }\end{array}$ & 18.9.2014 \\
\hline Kettunen, Pauli & $\begin{array}{l}\text { Professor of Political History, } \\
\text { University of Helsinki }\end{array}$ & 26.5.2014 \\
\hline Kivinen, Lauri & $\begin{array}{l}\text { Former Head of Communications, } \\
\text { Nokia }\end{array}$ & 3.9.2014 \\
\hline Kokkonen, Marketta & Former mayor, City of Espoo & 6.9.2014 \\
\hline Korhonen, Jarmo & Former Party Secretary, Centre Party & 20.8.2015 \\
\hline Koroma, Johannes & $\begin{array}{l}\text { Former Director General, } \\
\text { Confederation of Finnish Industries }\end{array}$ & 10.2 .2015 \\
\hline Korsbäck, Hans & Former deputy mayor, City of Espoo & 3.11 .2014 \\
\hline Kosonen, Mikko & $\begin{array}{l}\text { Former Head of Information } \\
\text { Management, Nokia }\end{array}$ & 20.11.2014 \\
\hline
\end{tabular}


List of Interviewees (Continued)

\begin{tabular}{|l|l|r|}
\hline \multicolumn{1}{|c|}{ Interviewee } & \multicolumn{1}{c|}{ Position(s) } & \multicolumn{1}{c|}{ Date } \\
\hline Kotka, Jan & $\begin{array}{l}\text { Former International Operations } \\
\text { Manager, Elcoteq }\end{array}$ & 25.10 .2014 \\
\hline Krogerus, Hannu & Lawyer; former adviser to Elcoteq & 6.8 .2014 \\
\hline Kurtén, Staffan & Business coach & 30.9 .2014 \\
\hline Kuusterä, Antti & Former researcher, Bank of Finland & 5.4 .2015 \\
\hline Lammervuo, Esko & CEO, Laukamo Group & 5.11 .2014 \\
\hline Lee, Kwan Min & $\begin{array}{l}\text { Professor, Nanyang Technological } \\
\text { University (NTU) }\end{array}$ & 25.5 .2018 \\
\hline Leinonen, Hannu & $\begin{array}{l}\text { Former Chief Editor, Kauppalehti } \\
\text { newspaper }\end{array}$ & $15.4 .2005 ;$ \\
\hline Liikanen, Erkki & Former governor, Bank of Finland & 27.4 .2008 \\
\hline Lindberg, Per & Former financial analyst & 4.2014 \\
\hline Lindén, Suvi & $\begin{array}{l}\text { Former Member of Parliament, } \\
\text { National Coalition Party }\end{array}$ & 12.2 .2015 \\
\hline $\begin{array}{l}\text { Lindholm, } \\
\text { Christian }\end{array}$ & $\begin{array}{l}\text { Entrepreneur; former User } \\
\text { Interfaces Director, Nokia }\end{array}$ & 19.6 .2015 \\
\hline Lindoff, Mats & Former CEO, MyOrigo & 9.2014 \\
\hline Lindqvist, Sebastian & Partner, IMS Talent & 30.9 .2014 \\
\hline Lindström, Kim & Investor & 25.10 .2014 \\
\hline Lundmark, Pekka & Former manager, Nokia; CEO, Nokia & 1.10 .2014 \\
\hline Moisio, Sami & $\begin{array}{l}\text { Professor of Geosciences, } \\
\text { University of Helsinki }\end{array}$ & 22.4 .2014 \\
\hline Murto, Risto & $\begin{array}{l}\text { CEO, Varma Pension Insurance } \\
\text { Company }\end{array}$ & 24.9 .2014 \\
\hline Neuvo, Yrjö & $\begin{array}{l}\text { Former Chief Technology Officer, } \\
\text { Nokia }\end{array}$ & 18.8 .2014 \\
\hline Nykänen, Pekka & $\begin{array}{l}\text { Former Development Manager, } \\
\text { Kauppalehti newspaper }\end{array}$ & $15.4 .2005 ;$ \\
\hline Nyström, Sebastian & Former manager, Nokia & 24.8 .2008 \\
\hline Ormala, Erkki & Former technology adviser, Nokia & 16.6 .2014 \\
\hline Palmu, Anne-Liisa & Former corporate lawyer, Nokia & 18.8 .2014 \\
\hline Pauly, François & $\begin{array}{l}\text { Former Director, Elcoteq; former } \\
\text { CEOxembourgeoise }\end{array}$ & 3.6 .2015 \\
\hline
\end{tabular}


List of Interviewees (Continued)

\begin{tabular}{|c|c|c|}
\hline Interviewee & Position(s) & Date \\
\hline Peltonen, Petri & $\begin{array}{l}\text { Under-secretary of State, Ministry of } \\
\text { Economic Affairs and Employment }\end{array}$ & 17.6.2014 \\
\hline Petersen, Soren Jenry & Former Head of CDMA Unit, Nokia & 15.6.2016 \\
\hline Piippo, Antti & $\begin{array}{l}\text { Former main shareholder and } \\
\text { Board Chairman, Elcoteq }\end{array}$ & $\begin{array}{r}\text { 25.3.2014; } \\
\text { 20.8.2014; } \\
\text { 2.9.2014; } \\
\text { 4.12.2014 }\end{array}$ \\
\hline Plummer, Bill & $\begin{array}{l}\text { Formerly executive, Huawei } \\
\text { Technologies; Americas executive, } \\
\text { Nokia }\end{array}$ & 16.3.2015 \\
\hline Pursiainen, Harri & $\begin{array}{l}\text { Director General, Ministry of } \\
\text { Transport and Communications }\end{array}$ & 18.6.2014 \\
\hline Pärnänen, Pekka & $\begin{array}{l}\text { Entrepreneur; former Director, } \\
\text { Finnode }\end{array}$ & 31.10 .2014 \\
\hline Rothstein, Bo & Professor, Universty of Gothenburg & 11.9.2015 \\
\hline Röning, Juha & $\begin{array}{l}\text { Professor in Information } \\
\text { Technology, University of Oulu }\end{array}$ & 19.8.2014 \\
\hline Saarinen, Matti & $\begin{array}{l}\text { Former Communications } \\
\text { Director, Nokia; Chairman, Kreab }\end{array}$ & $\begin{array}{r}17.4 .2014 \\
3.10 .2014 \\
\end{array}$ \\
\hline $\begin{array}{l}\text { Saarnivaara, } \\
\text { Veli-Pekka }\end{array}$ & Former Director General, Tekes & 5.8.2014 \\
\hline Samad, Abdul & Mobile phone salesman & 7.1.2015 \\
\hline Sandelin, Martin & $\begin{array}{l}\text { Author; former Investor Relations } \\
\text { Director, Nokia }\end{array}$ & 16.12 .2014 \\
\hline Sasi, Kimmo & $\begin{array}{l}\text { Former Member of Parliament, } \\
\text { National Coalition Party }\end{array}$ & 11.2014 \\
\hline Savisalo, Hannu & Chairman and CEO, Savcor Group & 18.6.2014 \\
\hline Saxenian, AnnaLee & $\begin{array}{l}\text { Dean and Professor, School of } \\
\text { Information, University of } \\
\text { California, Berkeley }\end{array}$ & 21.10 .2017 \\
\hline Seligson, Peter & $\begin{array}{l}\text { Entrepreneur; former head, Alfred } \\
\text { Berg Finland }\end{array}$ & 25.9.2014 \\
\hline Seppälä, Timo & $\begin{array}{l}\text { Researcher, Etla Economic } \\
\text { Research Instutute }\end{array}$ & 4.2 .2015 \\
\hline
\end{tabular}


List of Interviewees (Continued)

\begin{tabular}{|c|c|c|}
\hline Interviewee & $\operatorname{Position}(s)$ & Date \\
\hline Siilasmaa, Risto & Former Board Chairman, Nokia & 27.8.2018 \\
\hline Siimes, Suvi-Anne & $\begin{array}{l}\text { Former Member of Parliament, } \\
\text { Left Alliance }\end{array}$ & 8.10 .2014 \\
\hline Simonson, Rick & $\begin{array}{l}\text { Former Chief Financial Officer, } \\
\text { Nokia }\end{array}$ & 11.10 .2014 \\
\hline Sjöblom, Magnus & $\begin{array}{l}\text { Vice-President of Finance, Sitra } \\
\text { Innovation Fund }\end{array}$ & 10.6.2015 \\
\hline Sjöman, Henry & Former executive, Elcoteq & 28.5.2014 \\
\hline Solttila, Heikki & $\begin{array}{l}\text { Financial counsellor, Ministry of } \\
\text { Finance }\end{array}$ & 13.4.2015 \\
\hline Spängs, Thorbjörn & $\begin{array}{l}\text { Former Head of Business Desk, } \\
\text { Dagens Nyheter }\end{array}$ & 30.3.2005 \\
\hline Sténson, Henry & $\begin{array}{l}\text { Former Communications } \\
\text { Director, Ericsson }\end{array}$ & 2.2010 \\
\hline Strandberg, Ove & Former employee, Nokia & 9.2 .2015 \\
\hline Sundqvist, Ulf & $\begin{array}{l}\text { Former Member of Parliament, } \\
\text { Social Democratic Party }\end{array}$ & 7.10.2014 \\
\hline Suominen, Arja & $\begin{array}{l}\text { Former Communications } \\
\text { Director, Nokia }\end{array}$ & $\begin{array}{r}18.4 .2005 \\
2.2 .2010 \\
6.3 .2014\end{array}$ \\
\hline Sutinen, Teija & $\begin{array}{l}\text { Former Head of Business Desk, } \\
\text { Helsingin Sanomat }\end{array}$ & $\begin{array}{l}\text { 15.4.2005; } \\
\text { 24.8.2008 }\end{array}$ \\
\hline Söderling, Petra & $\begin{array}{l}\text { Entrepreneur; former Software } \\
\text { Manager, Nokia }\end{array}$ & 9.9.2014 \\
\hline Taimi, Maija & $\begin{array}{l}\text { Former Head of Corporate } \\
\text { Communications, Nokia }\end{array}$ & 2.12.2014 \\
\hline Tallberg, Andreas & CEO, G. W. Sohlberg & 15.8.2014 \\
\hline Tilli, Kari & Former Start-ups Director, Tekes & 1.9.2014 \\
\hline Törnwall, Michael & $\begin{array}{l}\text { Former journalist, Dagens Industri } \\
\text { newspaper }\end{array}$ & 4.2005 \\
\hline Vanhanen, Jorma & $\begin{array}{l}\text { Former shareholder and } \\
\text { executive, Elcoteq }\end{array}$ & 27.1.2015 \\
\hline Vanhanen, Matti & Member of Parliament, Centre Party & 5.5.2014 \\
\hline
\end{tabular}


List of Interviewees (Continued)

\begin{tabular}{|l|l|r|}
\hline \multicolumn{1}{|c|}{ Interviewee } & \multicolumn{1}{c|}{ Position(s) } & \multicolumn{1}{c|}{ Date } \\
\hline Vasara, Antti & $\begin{array}{l}\text { President and CEO, VTT } \\
\text { (Technical Research Centre of } \\
\text { Finland Ltd) }\end{array}$ & 31.8 .2018 \\
\hline Virtanen, Erkki & $\begin{array}{l}\text { Former Permanent Secretary, } \\
\text { Ministry of Employment and the } \\
\text { Economy }\end{array}$ & 9.6 .2014 \\
\hline Väänänen, Johannes & Former CTO, MyOrigo & 16.9 .2014 \\
\hline Väinölä, Petri & $\begin{array}{l}\text { Former executive, Nokia and } \\
\text { Elcoteq }\end{array}$ & 3.11 .2014 \\
\hline Wendell, Michel & Investor, Nexit Ventures & 13.10 .2016 \\
\hline Westlund, Jorma & $\begin{array}{l}\text { Former Political Secretary to } \\
\text { Prime Minister Paavo Lipponen }\end{array}$ & 2015 \\
\hline Wiklund, Henry & $\begin{array}{l}\text { Former President, Society of } \\
\text { Swedish Literature in Finland }\end{array}$ & 7.4 .2014 \\
\hline Woolcock, Keith & Former telecom analyst, Nomura & $4.2005 ;$ \\
\hline $\begin{array}{l}\text { Yli-Saunamäki, } \\
\text { Tapani }\end{array}$ & Former employee, Nokia & 29.8 .2014 \\
\hline Zilliacus, Thomas & Former executive, Nokia & 7.8 .2014 \\
\hline
\end{tabular}




\section{References}

Abraham, R. (2006). Mobile phones and economic development: Evidence from the fishing industry in India. International Conference on Information and Communication Technologies and Development, 48-56. Abrami, R. M., Kirby, W. C., \& McFarlan, F. W. (2014). Why China can't innovate. Harvard Business Review, 92(3), 107-111.

Ahonen, T. T. (2013). Communities Dominate Brands. https://communities -dominate.blogs.com/brands/

Ala-Fossi, M. (2018, 27 April). Miten Suomesta tuli mobiilidatan käytön kärkimaa? [How did Finland become the front runner in mobile data?]. Paper presented at the Median ja Viestinnän Tutkimuksen Päivät.

Ala-Fossi, M., \& Bonet, M. (2018). Who's afraid of a pan-European spectrum policy? The EU and the battles over the UHF broadcast band. International Journal of Communication, 12, 22.

Alcacer, J., Khanna, T., \& Furey, M. (2011). Nokia: The burning platform. Boston, MA: Harvard Business School.

Alcacer, J., Khanna, T., \& Snively, C. (2015). The rise and fall of Nokia. Boston, MA: Harvard Business School.

Ali-Yrkkö, J. (2000). Nokia: A big company in a small country. Etla.

Ali-Yrkkö, J. (2001a). Nokia's network: Gaining competitiveness from co-operation. Taloustieto. 
Ali-Yrkkö, J. (2001b). The role of Nokia in the Finnish economy. Finnish Economy and Society, 1, 72-80.

Ali-Yrkkö, J. (2008). Essays on the impacts of technology development and ReD subsidies. Etla.

Ali-Yrkkö, J. (Ed.). (2010). Nokia and Finland in a sea of change. Etla.

Ali-Yrkkö, J., Rouvinen, P., Seppälä, T., \& Ylä-Anttila, P. (2011). Who captures value in global supply chains? Case Nokia N95 smartphone. Journal of Industry, Competition and Trade, 11(3), 263-278.

Andriopoulos, C., \& Lewis, M. W. (2009). Exploitation-exploration tensions and organizational ambidexterity: Managing paradoxes of innovation. Organization Science, 20(4), 696-717.

Ängeslevä, P. (2010). Mies Suomi-brändin takana [The man behind the Finland brand]. Suomen Kuvalehti, 29/2010.

Aromäki, J. (1995, 1 October). Ollilan opit purevat [The learnings of Ollila bite]. Helsingin Sanomat. http://www.hs.fi/paivanlehti/arkisto /OLLILAN+OPIT+PUREVAT+Nokia+on+kasvanut+vauhtia+joka +kirjataan+historiaan+Toimitusjohtaja+tiet $\% \mathrm{C} 3 \% \mathrm{~A} 4 \% \mathrm{C} 3 \% \mathrm{~A} 4+\mathrm{ett}$ $\%$ C3\%A4+kasvu+jatkuu+vain+jos+suuruus+ei+sokeuta/aa951001001 ?src=haku\&ref=arkisto $\% 2 \mathrm{~F}$

Aronczyk, M. (2013). Branding the nation: The global business of national identity. Oxford University Press.

Austin, S. (2013, 11 July). Nokia sees no need to sell handset business. The Wall Street Journal. http://blogs.wsj.com/digits/2013/07/11/nokia-sees -no-need-to-sell-handset-business/

Autio, J. (1996). Korot suomessa 1862-1952 [Interest rates in Finland 1862-1952]. Suomen Pankki. https://helda.helsinki.fi/bof/handle /123456789/7637

Auvinen, O. (2013, 7 September). Suomalaisuus ei riitä nokialle [Being Finnish is not enough for Nokia]. MTV Uutiset. https://www.mtvuutiset .fi/artikkeli/kommentti-suomalaisuus-ei-riita-nokialle/2334736

Ban, C. (2016). Ruling ideas: How global neoliberalism goes local. Oxford University Press.

Banker, R., Cao, Z., Menon, N. M., \& Mudambi, R. (2012). The Red Queen in action: The longitudinal effects of capital investments in the mobile telecommunications sector. Industrial and Corporate Change, 22(5), 1195-1228.

Barnett, W. P., \& Hansen, M. T. (1996). The Red Queen in organizational evolution. Strategic Management Journal, 17(S1), 139-157.

Bennett, D. (2014, 21 June). Clayton Christensen responds to New Yorker takedown of 'disruptive innovation'. Bloomberg. http://www.bloomberg 
.com/news/articles/2014-06-20/clayton-christensen-responds-to -new-yorker-takedown-of-disruptive-innovation

Best, J. (2013, 3 September). Finland to become Microsoft's mobile R\&D hub after Nokia buyout. ZD Net. http://www.zdnet.com/article /finland-to-become-microsofts-mobile-r-d-hub-after-nokia-buyout/ Billig, M. (1995). Banal nationalism. Sage Publications.

Blåfield, A. (1999, 21 March). Kuka valvoo Jorma Ollilaa? [Who controls Jorma Ollila?]. Helsingin Sanomat. http://www.hs.fi/paivanlehti /arkisto/Kuka+valvoo+Jorma+Ollilaa/aaHS990321SI1MA01 rbk?src $=$ haku\&ref $=$ arkisto $\% 2 \mathrm{~F}$

Blom, A. (2018). Taloudelliset eturyhmät politiikan sisäpiirissä: Tutkimus liike-elämän poliittisesta vaikuttamisesta kolmikantaisessa suomessa 1968-2011 [Economic interest groups as insiders in politics: A study of political lobbyism in tripartite Finland 1968-2011] [PhD thesis].

Brandenburger, A. M., \& Nalebuff, B. J. (2002). Co-opetition. Profile Books. Brander, R. (2019). Finland och den tidiga västintegrationen: Hjalmar J. Procopé och europarörelsen 1948-1954 [Finland and the early integration with the West: Hjalmar J. Procopé and the European movement 1948-1954] [PhD thesis].

Brors, H. (2015). Från Harpsundsdemokrati till innovationsråd: Umgänge med allt mindre betydelse [From the Harpsund democracy to innovation council: Relations with diminishing importance]. https://henrikbrors.wordpress.com/2015/02/24/fran-harpsunds demokrati-till-innovationsrad/

Broughton, P. D. (2009, 1 March). Harvard's masters of the apocalypse. The Sunday Times. https://www.thetimes.co.uk/article/harvards-masters -of-the-apocalypse-rrv56z2lsrh

Bruun, S., \& Wallén, M. (2000). Boken om Nokia [The book about Nokia]. Fischer.

Burns, J., \& Nielsen, K. (2006). How do embedded agents engage in institutional change? Journal of Economic Issues, 40(2), 449-456.

Burt, T. (1999, 24 March). Hello world, Helsinki calling. Financial Times. Business Oulu. (2020, 8 May). Oulun seudun elinkeinokatsaus 1/2020 [Economic overview of the Oulu region 1/2020]. Business Oulu. https://www.businessoulu.com/media/2019/pdf/oulun_elinkei nokatsaus_1_2020-final.pdf

Calhoun, C. (2002). The class consciousness of frequent travelers: Toward a critique of actually existing cosmopolitanism. South Atlantic Quarterly, 101(4), 869-897. 
Campbell, J. L. (1998). Institutional analysis and the role of ideas in political economy. Theory \& Society, 27(3), 377-409.

Campbell, K., Diffley, J., Flanagan, B., Morelli, B., O’Neil, B., \& Sideco, F. (2019). The 5G economy: How $5 \mathrm{G}$ technology will contribute to the global economy. IHS. https://cdn.ihs.com/www/pdf/IHS-Technology -5G-Economic-Impact-Study.pdf

Carroll, C. E. (2002). The strategic use of past and future in organizational research. Journal of Organizational Change Management Volume, 15(6), 556-562.

Chan, J., Selden, M., \& Nqai, P. (2020). Dying for an iPhone: Apple, Foxconn and the lives of China's workers. Haymarket Books and Pluto Press.

Chaney, P. K., \& Lewis, C. M. (1995). Earnings management and firm valuation under asymmetric information. Journal of Corporate Finance, 1(3-4), 319-345.

Chaykowski, K. (2017, 22 June). Mark Zuckerberg gives Facebook a new mission. Forbes. https://www.forbes.com/sites/kathleenchaykowski /2017/06/22/mark-zuckerberg-gives-facebook-a-new-mission/

Chipchase, J., \& Steinhardt, S. (2013). Hidden in plain sight: How to create extraordinary products for tomorrow's customers. HarperBusiness.

Christensen, C. (1997). The innovator's dilemma: When new technologies cause great firms to fail. Harvard Business Press.

Clinch, M. (2014, 13 October). How Apple prompted this country's downgrade. CNBC. https://www.cnbc.com/2014/10/13/how-apple -prompted-this-countrys-downgrade.html

Clive, H., Jashvir, B., Rass, K., Rentrop, V., Parumog, E., \& Raitasaari, E. P. (2020). Beyond Nokia. Facebook. https://www.facebook.com /groups/132264426873204/

Cobham, A. (2013, 22 July). Corrupting perceptions: Why transparency international's flagship corruption index falls short. Foreign Policy. https://foreignpolicy.com/2013/07/22/corrupting-perceptions/

Collins, J. (2001). Good to great: Why some companies make the leap ... and others don't. Harper Business.

Comaroff, J. L., \& Comaroff, J. (2009). Ethnicity, inc. University of Chicago Press.

Corcoran, F. (2009). Exploring the European elite sphere. Journalism Studies, 10(1), 100.

Cord, D. (2014). The decline and fall of Nokia. Helsinki: Schildts \& Söderströms. 
Council for Mass Media in Finland. (2014). Guidelines for journalists. Croissant, J. L. (2014). Agnotology: Ignorance and absence or towards a sociology of things that aren't there. Social Epistemology, 28(1), 4-25.

Davis, A. (2000). Public relations, business news and the reproduction of corporate elite power. Journalism, 1(3), 282-304.

Davis, A. (2007). The mediation of power: A critical introduction. Routledge.

Denning, S. (2013, 26 June). The origin of 'the world's dumbest idea': Milton Friedman. Forbes. http://www.forbes.com/sites/stevedenning /2013/06/26/the-origin-of-the-worlds-dumbest-idea-milton -friedman/\# ea5f369214ca

Denning, S. (2017, 17 July). Making sense of shareholder value: 'The world's dumbest idea'. Forbes. https://www.forbes.com/sites/stevedenning /2017/07/17/making-sense-of-shareholder-value-the-worlds -dumbest-idea/

DeSouza, S. I., Rashmi, M. R., Vasanthi, A. P., Joseph, S. M., \& Rodrigues, R. (2014). Mobile phones: The next step towards healthcare delivery in rural India? PloS One, 9(8), e104895.

Deuze, M. (2005). What is journalism? Journalism, 6(4), 442-464.

DiMaggio, P. (1988). Interest and agency in institutional theory. In L. G. Zucker (Ed.), Institutional patterns and organizations (pp. 3-21). Ballinger.

Djelic, M., \& Quack, S. (2003). Globalization and institutions: Redefining the rules of the economic game. Edward Elgar.

Dougal, C., Engelberg, J., Garcia, D., \& Parsons, C. A. (2012). Journalists and the stock market. Review of Financial Studies, 25(3), 639-679.

Doz, Y., \& Kosonen, M. (2008). The dynamics of strategic agility: Nokia's rollercoaster experience. California Management Review, 50(3), 95-118. https://doi.org/10.2307\%2F41166447

Doz, Y., \& Kosonen, M. (2011). Letter to the editor: Nokia and strategic agility: A postscript. California Management Review, 53(4), 154-156.

Doz, Y., \& Wilson, K. (2017). Ringtone: Exploring the rise and fall of Nokia in mobile phones. Oxford University Press.

Drinkard, J. (2003, 24 June). Private funds will cover bulk of party conventions. USA Today. http://usatoday30.usatoday.com/news /politicselections/2003-06-23-conventions-usat_x.htm

Dyck, A., \& Zingales, L. (2002). The bubble and the media. In P. K. Cornelius, \& B. Kogut (Eds.), Corporate governance and capital flows in a global economy (pp. 83-102). Oxford University Press. 
Ericsson. (2019). 10 hot consumer trends 2030: The internet of senses. Retrieved from https://www.ericsson.com/en/reports-and-papers /consumerlab/reports/10-hot-consumer-trends-2030

Esmaeili, M., \& Zeephongsekul, P. (2010). Seller-buyer models of supply chain management with an asymmetric information structure. International Journal of Production Economics, 123(1), 146-154.

Etzkowitz, H. (2008). The triple-helix: The university-government innovation in action. Routledge.

European Commission. (2020). The digital economy and society index (DESI). Retrieved from https://ec.europa.eu/digital-single-market /en/desi

Finland Toolbox. (2019). Country ranking - least corrupt. Retrieved from https://toolbox.finland.fi/life-society/country-ranking-least -corrupted/

Finnish patent and registration office. (2020). Trademark database. Retrieved from https://www.prh.fi/fi/tavaramerkit/tavaramerkkiti etokannat/tavaramerkkitietokanta.html

Forohaar, R. (2010, 16 August). The best countries in the world. Newsweek. http://europe.newsweek.com/best-countries-world-71817 ?rm=eu

Forsman, P., \& Savolainen, E. (2010). Osakkeiden takaisinostot kaunistelevat vaihtotasetta [Share backbuys sugars current account]. Tilastokeskus. http://tilastokeskus.fi/artikkelit/2010/art_2010-11-10_001 .html? s=0

Friedman, M. (1970, 13 September). The social responsibility of business is to increase its profits. The New York Times Magazine. https: //www.nytimes.com/1970/09/13/archives/a-friedman-doctrine-the -social-responsibility-of-business-is-to.html.

Frilander, J. (2013, 3 September). Nokia on ollut suomalaisille enemmän kuin liikeyritys [Nokia has been more than a company to Finns]. Uutiset. https://yle.fi/uutiset/3-6812950

Gabriel, Y. (2000). Storytelling in organizations: Facts, fictions, and fantasies. Oxford: Oxford University Press.

Gassmann, O. (2014, 8 September). The danger in missing the innovation moment. Financial Times. http://www.ft.com/intl/cms $/ \mathrm{s} / 2$ /b2ef363c-31c4-11e4-b377-00144feabdc0.html\#axzz3aZKI3KjU

Giachetti, C., Lampel, J., \& Pira, S. L. (2017). Red Queen competitive imitation in the UK mobile phone industry. Academy of Management Journal, 60(5), 1882-1914. 
Giachetti, C., \& Marchi, G. (2017). Successive changes in leadership in the worldwide mobile phone industry: The role of windows of opportunity and firms' competitive action. Research Policy, 46(2), 352-364.

Gibson, C. B., \& Birkinshaw, J. (2004). The antecedents, consequences, and mediating role of organizational ambidexterity. Academy of Management Journal, 47(2), 209-226.

Glimstedt, H. (2001). Competitive dynamics of technological standardization: The case of third generation cellular communications. Industry and Innovation, 8(1), 49-78.

Goggin, G. (2006). Cell phone culture: Mobile technology in everyday life. Routledge.

Golding, P. (1981). The missing dimensions-news media and the management of social change. In E. Katz, \& T. Szecskö (Eds.), Mass media and social change (pp. 63-82). Sage Publications.

Gow, D. (2008, January 23,). Germans protest at 'caravan capitalism'. The Guardian Retrieved from https://www.theguardian.com/business/2008 /jan/23/europe.northernrock

Granovetter, M. (1985). Economic action and social structure: The problem of embeddedness. American Journal of Sociology, 91(3), 481-510.

Granovetter, M. S. (1992). Economic institutions as social constructions: A framework for analysis. Acta Sociologica, 35(1), 3-11.

Gross, M., \& McGoey, L. (2015). Routledge international handbook of ignorance studies. Routledge.

Häikiö, M. (2001a). Nokia Oyj:n Historia 1: Fuusio: Yhdistymisten Kautta Suomalaiseksi Monialayritykseksi 1865-1982 [The history of Nokia 1: Fusion: A Finnish conglomerate through mergers 1865-1982]. Edita.

Häikiö, M. (2001b). Nokia Oyj: $n$ Historia 2: Sturm und Drang: Suurkaupoilla Eurooppalaiseksi Elektroniikkayritykseksi 1983-1991 [The history of Nokia 2: Sturm und Drang: A European big electronics company through big deals 1983-1991]. Edita.

Häikiö, M. (2001c). Nokia Oyj:n historia 3: Telekommunikaation maailmanvalloitus 1992-2000 [The history of Nokia, 3: Telecommunications conquering the world 1992-2000]. Edita.

Häikiö, M., \& Virtanen, O. V. (2002). Nokia: The inside story. Edita.

Hakkarainen, A. (2009). Behind the screen: Nokia's success story in an industry of navel-gazing executives and crazy frogs. Readme.

Hämäläinen, U. (2014, 20 October). Jarmo Korhonen kirjassaan: Suuryritykset rahoittivat keskustaa 1980-luvulla [Jarmo Korhonen 
in his book: Big companies funded the centre in the 1980s]. Helsingin Sanomat. https://www.hs.fi/politiikka/art-2000002770756 .html? share $=$ eca1d70488a7bf7c412c304a9667e16a

Hannas, W. C., Mulvenon, J., \& Puglisi, A. B. (2013). Chinese industrial espionage: Technology acquisition and military modernisation. Routledge.

Hänninen, J. (2014). Veroparatiisit ja Suomi: eli kuinka liituraitamafia pyörittää varjotaloutta ja laskun siitä maksamme me [Tax paradises and Finland: how a white collar mafia works a shadow economy while we are paying the bill]. HS-kirjat.

Hargadon, A. B., \& Douglas, Y. (2001). When innovations meet institutions: Edison and the design of the electric light. Administrative Science Quarterly, 46(3), 476-501.

He, Z., Lim, K., \& Wong, P. (2006). Entry and competitive dynamics in the mobile telecommunications market. Research Policy, 35(8), $1147-1165$.

He, Z., \& Wong, P. (2004). Exploration vs. exploitation: An empirical test of the ambidexterity hypothesis. Organization Science, 15(4), 481-494.

Heino, T. (2011). Työt, tulot ja optiot [Work, income and options]. Yhteiskuntapolitiikka, 76(5), pp. 523-534.

Helleiner, E., \& Pickel, A. (Eds.). (2005). Economic nationalism in a globalizing world. Cornell University Press.

Helsingin Sanomat. (2007, 5 September). Hyytävää journalismia [Chilling journalism].

Henisz, W. J. (2017). Corporate diplomacy: Building reputations and relationships with external stakeholders. Routledge.

Hickins, M. (2009, 3 September). Nokia failing to connect with U.S. culture. CBS News. https://www.cbsnews.com/news/nokia-failing-to -connect-with-us-culture/

Hill, A. (2013, 3 September). The search for a culprit in the Nokia whodunit. Financial Times. https://www.ft.com/content/65a51e36-1484 -11e3-a2df-00144feabdc0

Hirschman, A. O. (1970). Exit, voice, and loyalty: Responses to decline in firms, organizations, and states. Cambridge, Mass.: Harvard University Press.

Holmén, M. (2009). Visit finland-matkailubrändi [The visit Finland tourism brand]. Visit Finland.

Hon Hai. (2020). About Hon Hai. Retrieved from https://www.foxconn .com/en/GroupProfile.html 
Hong, Y. (2017a). Networking China: The digital transformation of the Chinese economy. University of Illinois Press.

Hong, Y. (2017b). Reading the 13th five-year plan: Reflections on China's ICT policy. International Journal of Communication, 11, 1755-1774. Honkapohja, S., Koskela, E., Leibfritz, W., \& Uusitalo, R. (2009). Economic prosperity recaptured: The Finnish path from crisis to rapid growth. MIT Press.

Hulkko, K., \& Pöysä, J. (1988). Vapaa markka: Teot ja tarinat [the free markka: Actions and tales]. Juva: Atena Kustannus.

Ibison, D. (2007, 4 September). All is not as it appears in frozen land. Financial Times. https://www.ft.com/content/e0954014-57d7-11dc $-8 \mathrm{c} 65-0000779 \mathrm{fd} 2 \mathrm{ac}$

IGI Consulting. (2000). India telecom vol 4: Overview of the Indian market 1999-2000. IGI. http://www.igigroup.com/st/pages/indiav4.html

Ilta-Sanomat. (2011, 21 January). Kiviniemi luottaa Elopiin [Kiviniemi trusts Elop]. Uutiset. https://www.is.fi/tyoelama/art-2000001699160 .html

Isaacson, W. (2011). Steve Jobs. Simon \& Schuster.

Isaacson, W. (2012). The real leadership lessons of Steve Jobs. Harvard Business Review, 90(4), 92-102.

Iversen, E. J., \& Richard, T. (2006). Standards dynamics and industrial organization in the mobile phone sector. Info, 8(4), 33-48.

Iversen, M. J., \& Thue, L. (2008). Introduction: Creating Nordic capitalism-the business history of a competitive periphery. In S. Fellman, M. J. Iversen, H. Sjögren, \& L. Thue (Eds.), Creating Nordic capitalism: The business history of a competitive periphery. Palgrave Macmillan.

James, J. (2016). The impact of mobile phones on poverty and inequality in developing countries. Springer.

Jauhiainen, J. S. (2007). Men, money and mobile phones: Tracing the technology discourse in finnish newspapers. Technology in Society, 29(1), 79-91.

Jennings, J. (2012). The reinventors: How extraordinary companies pursue radical continuous change. Penguin.

Junkkari, M. (1998, 10 April). Oy Nokia yliopisto ab [Nokia university inc.]. Helsingin Sanomat. https://www.hs.fi/talous/art-2000003709090.html

Juurus, K. (2005). Nokian laki [The Nokia law]. MOT, Finnish Public Broadcasting.

Karlberg, L. A. (2005, 1 October). Ericsson byter slogan [Ericsson changes its slogan]. Ny Teknik. https://www.nyteknik.se/digitalisering /ericsson-byter-slogan-6442942 
Kao, J. (2007). Innovation nation: How America is losing its innovation edge, why it matters, and what we can do to get it back. Free Press.

Karlsson, S., \& Lugn, A. (2009). Changing the world. The story of Lars Magnus Ericsson and his successors. Sellin \& Partner.

Kathuria, R., Kedia, M., \& Bagchi, K. (2019). Competition issues in India's mobile handset industry. Indian Council for Research on International Economic Relations. https://icrier.org/pdf/Competition -Issues-in-India-Mobile-Handset-Industry.pdf

Kim, Y. (2018, 12 November). China's race to dominate AI. Wall Street Journal. https://www.wsj.com/articles/chinas-race-to-dominate-ai $-1542037623$

Klee, K., \& Bensko, J. (1999, 23 May). The future is Finnish. Newsweek. http://www.newsweek.com/id/88341

Knowledge@Wharton. (2007, 23 August). How did Nokia succeed in the Indian mobile market, while its rivals got hung up? Knowledge@ Wharton. https://knowledge.wharton.upenn.edu/article/how-did -nokia-succeed-in-the-indian-mobile-market-while-its-rivals-got -hung-up/

Koikkalainen, P., \& Riepula, E. (2009). Näin valta ostetaan. Lyhyt oppimäärä politttisesta korruptiosta Suomessa 2006-2009 [How power is bought: A short history of political corruption in Finland 2006-2009]. WSOY.

Korhonen, J. (2014). Väyrysen valtakunta [The kingdom of Väyrynen]. Tammi.

Korhonen, J. (2015). Maan tapa [The habit of the country]. Tammi.

Korhonen, J., \& Kotila, P. (Eds.). (2008). Toivoa, tahtoa, tarmoa: Tekes 25 vuotta [Wishes, will, vitality: Tekes 25 years]. Tekes.

Kortelainen, J. (1999). The river as an actor-network: The Finnish forest industry utilization of lake and river systems. Geoforum, 30(3), 235-247.

Kotter, J. P. (1995). Leading change: Why transformation efforts fail. Harvard Business Review, 73(2), 59-67.

Kruchten, P., Nord, R. L., \& Ozkaya, I. (2012). Technical debt: From metaphor to theory and practice. IEEE Software, 29(6), 18-21.

Kuisma, M. (1999). Suomi Nokiana, Nokia Suomena [Finland as Nokia, Nokia as Finland]. In M. Löytönen, \& L. Kolbe (Eds.), Suomi: Maa, kansa, kulttuurit [Finland: Country, people, cultures] (pp. 171-183). Suomalaisen Kirjallisuuden Seura.

Kuisma, M., \& Seppänen, P. (2015). Suomen pahimmat businesmokat: tarinoita huippujohtamisesta [The worst business mistakes in Finland: Stories about top management]. Siltala. 
Kulju, M. (2002). Oulun ihmeen tekijät [The miracle workers of Oulu]. Gummerus.

Kurtti, N. (2019). Life in the technology hub of the world: My time at Valo Ventures in Silicon Valley. Fortum. https://www.fortum.com /media/2019/11/life-technology-hub-world-my-time-valo-ventures -silicon-valley

Laamanen, S. (2013). Suomi-kuva suomalaisessa rocklyriikassa vuosina 1980-1999 [The Finland brand in Finnish rock lyrics 1980-1999] [Master's thesis].

Laaninen, T. (2005). Se on ihan Matti [It's so Matt]. Helsinki: Maahenki. Lamberg, J., Lubinaite, S., Ojala, J., \& Tikkanen, H. (2019). The curse of agility: The Nokia corporation and the loss of market dominance in mobile phones, 2003-2013. Business History, 1-47.

Lassila, A. (2006a, 19 May). Media voisi jättää pörssikurssit julkaisematta [The media should not publish stock prices]. Helsingin Sanomat. https://www.hs.fi/talous/art-2000004397760.html?share $=\mathrm{e} 805490 \mathrm{~b} 3 \mathrm{a} 48 \mathrm{bcfbc00437 \textrm {c } 9 8 2 0 0 7 \mathrm { ffd }}$

Lassila, A. (2006b, 19 May). Jorma Ollila kaipaa Suomeen enemmän riskinottoa [Jorma Ollila wants more risk taking]. Helsingin Sanomat. https://www.hs.fi/talous/art-2000004397767.html?share=2390042d 2680abf4726393f18fe2981b

Lazonick, W. (2017). Innovative enterprise solves the agency problem: The theory of the firm, financial flows, and economic performance. Institute for New Economic Thinking Working Paper Series, 62.

Lee, K.-F. (2018). AI superpowers: China, Silicon Valley, and the new world order. Houghton Mifflin Harcourt.

Lesser, C. (2008). Market openness, trade liberalisation and innovation capacity in the Finnish telecom equipment industry. Paris: OECD.

Lindén, C.-G. (1986, 20 June). Nokia-en stat i staten [Nokia-a State in the State]. Hufvudstadsbladet.

Lindén, C. (2011, 12 February). Bill Gates nya slav [The new slave of Bill Gates]. Hufvudstadsbladet.

Lindén, C. (2012). National champions in combat: Nokia, Ericsson and the sensemaking of business news [PhD thesis].

Lindén, C. (2013). A small exclusive circle. Nordicom Review, 34, 127-40.

Littmann, D., Wilson, P., Wigginton, C., Haan, B., Fritz, J., Hunt, B, Krause, T., Sivertson, E., \& Zhu, V. (2018). 5G: The chance to lead for a decade. Deloitte.

Lounasmeri, L. (2010). Kansallisen konsensuskulttuurin jäljillä: Globalisaatioajan Suomi Helsingin Sanomissa [On the track of national consensual culture: Times of globalization in Helsingin Sanomat] [PhD thesis]. 
Maabrändivaltuuskunta.(2010). TehtäväSuomelle: miten Suomi ratkaisee maailman viheliäisimpiä ongelmia [A mission for Finland: How Finland will solve the most miserable problems in the world]. Foreign Ministry.

Madhani, P. M. (2017). Diverse roles of corporate board: Review of various corporate governance theories. The IUP Journal of Corporate Governance, 16(2), 7-28.

Mäkinen, M. (1995). Nokia saga: Kertomus yrityksestä ja ihmisistä, jotka muuttivat sen [Nokia Saga: A story about a firm and the people who changed it]. Gummerus.

Mäntylä, J. (2017, 1 January). Nokia-katastrofista uuteen nousuun: näin Oulusta kuoriutui Suomen Piilaakso [Bouncing back after Nokia catastrophe: How Oulu turned into Finland's Silicon Valley]. Talouselämä. https://www.talouselama.fi/uutiset/nokia-katastrofista - uuteen-nousuun-nain-oulusta-kuoriutui-suomen-piilaakso /14894f28-7b50-30b2-9b51-5c944f2a125e

March, J. G., \& Olsen, J. P. (1989). Rediscovering institutions: The organizational basis of politics. Free Press.

Mayer, M. S. (2009). The Eisenhower years. Infobase Publishing.

Mazzucato, M. (2013). The entrepreneurial state: Debunking public vs. private sector myths. Anthem Press.

McDonough, J., \& Egolf, K. (Eds.). (2015). The advertising age encyclopedia of advertising. Chicago, London: Fitzroy Dearburn Publishers.

McIntosh, N. (2004, 11 March). Dear diary... The Guardian. https: //www.theguardian.com/technology/2004/mar/11/newmedia .onlinesupplement

McLuhan, M. (1962). Gutenberg galaxy: The making of typographic man. University of Toronto Press.

Ménière, Y., Rudyk, Y., \& Valdes, J. (2017). Patents and the Fourth Industrial Revolution: The inventions behind digital transformation | December 2017. European Patent Office.

Merriden, T. (2001). Business the Nokia way: Secrets of the world's fastest moving company. Capstone.

Michelsen, K. (1996). Kari Kairamon unelma: Eurooppalainen Suomi [The dream of Kari Kairamo: A European Finland]. In T. Lemola, \& R. Lovio (Eds.), Miksi Nokia, Suomi [Why Nokia, Finland] (pp. 36-61). WSOY.

Microsoft. (2016). Microsoft selling feature phone business to FIH Mobile Ltd. and HMD Global, Oy. Microsoft. https://news.microsoft .com/2016/05/18/microsoft-selling-feature-phone-business-to-fih -mobile-ltd-and-hmd-global-oy/ 
Miettinen, A. (2014, 1 March). Nokian 20 vuoden tilinpäätös: Paljonko Suomi tienasi? [Balance sheet after Nokia's 20 years: How much did Finland earn?] Helsingin Sanomat. https://www.hs.fi/kuu kausiliite/art-2000002713241.html.

Miettinen, R. (2002). National innovation system: Scientific concept or political rhetoric. Helsinki: Edita.

Mikkonen, A. (2006, 28 April). Kännykkäklusterin huima nousu ja pako aasiaan [The vaulting rise of the mobile phone cluster and its flight to China]. Talouselämä. https://www.talouselama.fi/uutiset /kannykkaklusterin-huima-nousu-ja-pako-aasiaan/26a23cd5-070e -33f3-a3d0-f06bea3f4779

Miles, S. (2017). Stakeholder theory classification: A theoretical and empirical evaluation of definitions. Journal of Business Ethics, 142(3), 437-459.

Miller, M. H., \& Rock, K. (1985). Dividend policy under asymmetric information. Journal of Finance, 40(4), 1031-1051.

Milne, R. (2020,1 July). Nokia and Ericsson remain vulnerable in geopolitical 5G tussle. Financial Times. https://www.ft.com/content /1ac1db39-7817-4fe2-ace8-8b67714aafd6

Mitchell, R. K., Agle, B. R., \& Wood, D. J. (1997). Toward a theory of stakeholder identification and salience: Defining the principle of who and what really counts. Academy of Management Review, 22(4), 853-886.

Mittal, S., \& Mehar, M. (2012). How mobile phones contribute to growth of small farmers? Evidence from India. Quarterly Journal of International Agriculture, 51,3: 227-244.

Moen, E., \& Lilja, K. (2005). Change in coordinated market economies: The case of Nokia and Finland. In G. Morgan, R. Whitley, \& E. Moen (Eds.), Changing capitalisms?: Internationalization, institutional change, and systems of economic organization (pp. 352-382). Oxford University Press.

Moilanen, T., \& Rainisto, S. (2009). How to brand nations, cities and destinations: A planning book for place branding. Palgrave MacMillan.

Molander, S., Östberg, J., \& Kleppe, I. A. (2019). Swedish dads as a national treasure: Consumer culture at the nexus of the state, commerce, and consumers. In S. Askegaard, \& J. Östberg (Eds.), Nordic consumer culture: State, market and consumers (pp. 119-146). Palgrave McMillan.

Munir, K. A., \& Phillips, N. (2005). The birth of the 'Kodak moment': Institutional entrepreneurship and the adoption of new technologies. Organization Studies, 26(11), 1665-1687. 
Murgia, M., \& Gross, A. (2020, 27 March). Inside China's controversial mission to reinvent the internet. Financial Times. https://www.ft .com/content/ba94c2bc-6e27-11ea-9bca-bf503995cd6f

Myllylä, Y., \& Kaivo-oja, J. (2008, 10 December). Lex Nokia ampuu tykillä kärpästä [Lex Nokia is shooting mosquitoes with a cannon]. Kaleva. https://yrjomyllyla.files.wordpress.com/2011/06/kaleva-101208.jpg

Nazarenko, S. (2019). Korruptio Suomessa [Corruption in Finland]. Into.

Nelson, S. B., Jarrahi, M. H., \& Thomson, L. (2017). Mobility of knowledge work and affordances of digital technologies. International Journal of Information Management, 37(2), 54-62.

Nokia. (1996). Annual report 1996. https://web.lib.aalto.fi/fi/old/yritys palvelin/pdf/1996/enokia.pdf

Nokia. (2020). Creating the technology to connect the world: Nokia annual report on form 20-F 2019. https://www.nokia.com/system /files/2020-03/Nokia\%20Form\%2020F\%202019_0.pdf

Nordqvist, H. (2017). Simo Vuorilehto: Patriotti. Simo Vuorilehto.

North, D. C. (1990). Institutions, institutional change and economic performance. Cambridge University Press.

North, D. C. (2005). Understanding the process of economic change. Princeton University Press.

NTT Docomo. (2020). White paper: 5G evolution and 6G. Tokyo: NTT Docomo. Retrieved from https://www.nttdocomo.co.jp/english /binary/pdf/corporate/technology/whitepaper_6g/DOCOMO_6G _White_PaperEN_20200124.pdf

Nussbaum, B. (2007, 18 June). Clayton Christensen on the iPhone. Bloomberg. https://www.bloomberg.com/news/articles/2007-06-17 /clayton-christensen-on-the-iphone-dot

Nykänen, P., \& Salminen, M. (2014). Operaatio Elop [Operation Elop]. Teos.

Nylander, J. (2017). Shenzhen superstars: How China's smartest city is challenging Silicon Valley. CreateSpace Independent Publishing Platform.

Ocock, T. (2010, 8 November). Guest post: Symbian OS-one of the most successful failures in tech history. Extra Crunch. https://social .techcrunch.com/2010/11/08/guest-post-symbian-os-one-of-the -most-successful-failures-in-tech-history-2/

Oilinki, J. (2015). Korruptiorikollisuus 2014-2015 [Corruption 2014-2015]. National Bureau of Investigation. https://www.poliisi .fi/instancedata/prime_product_julkaisu/intermin/embeds 
/poliisiwwwstructure/31549_Korruptiorikollisuuskatsaus_2014 _-_2015_20150623.pdf?9e4314f06c9dd288

Olin, D. (2019, 14 December). Pekka Lundmark-idrottsentusiast och inflytelserik företagsledare [Pekka Lundmark-sports enthusiast and influential business manager]. Areena. https://areena.yle.fi/1 $-4666564$

Ollila, J., \& Saukkomaa, H. (2013). Mahdoton menestys. Otava.

Ollila, J., \& Saukkomaa, H. (2016). Against all odds: Leading Nokia from near catastrophe to global success. Maven House.

Open Secrets.org. (2020). Nokia inc. Retrieved from https://www .opensecrets.org/orgs/summary.php?id=D000036237\&cycle $=\mathrm{A}$

Paananen, V. (2019, 25 June). Salo haluaa älykaupungiksi, mutta mitä se tarkoittaa, ja miksi kumppanina on vakoilusta epäilty kiinalainen Huawei? [Salo wants to be a smart city, but what does it mean, and why the companion Chinese Huawei, accused of espionage?]. Helsingin Sanomat. https://www.hs.fi/talous/art-2000006152946.html

Paasonen, S., \& Pajala, M. (2010). Trashing the prime minister's bride: Public dismay and intertextual media. Critical Studies in Media Communication, 27(2), 174-192.

Paddison, L. (2018, 2 November). This country publishes everyone's income on 'National jealousy day'. Retrieved from https://www .huffpost.com/entry/finland-taxable-income-salary-transparency_n _5bdc520fe4b01ffb1d0170ec

Page, S. E. (2006). Path dependence. Quarterly Journal of Political Science, 1(1), 87-115.

Palmu-Joronen, A. (2009). Nokia-vuodet: Mitä johtamisesta voi oppia [The Nokia years: What can be learned about management?]. Atena.

Pettersson, M. (2014, 16 November). HS ja 2000-luku: Nokia kolme kertaa päivässä [HS and 2000s: Nokia three times a day]. Helsingin Sanomat. https://www.hs.fi/sunnuntai/art-2000002777546.html

Pietiläinen, T. (2006, 26 January). Nokia, isot pörssiyhtiöt ja bioala saaneet eniten julkista Tekes-rahaa [Nokia, big listed companies and biotech get most funding from Tekes]. Helsingin Sanomat. https: //www.hs.fi/talous/art-2000004370209.html

Pietiläinen, T. (2015, 16 April). Nokia edelleen suurin Tekesin rahoituksen saajista [Nokia still biggest recipient of Tekes funding]. Helsingin Sanomat. https://www.hs.fi/talous/art-2000002816712.html

Pitkänen, P. (2013, 28 May). Nokian Suomi-linnake murtuu-Samsung meni ohi [The Finnish empire of Nokia broken-Samsung has 
passed]. Ilta-Sanomat. https://www.is.fi/digitoday/mobiili/art-2000 001797426.html

Poutanen, M. (2019). Business logics: Co-option of media discourse by pro-market arguments in the case of Nokia in Finland. In N. M. Montessori, M. Farrelly, \& J. Mulderrig (Eds.), Critical policy discourse analysis (pp. 122-146). Edward Elgar Publishing.

Proctor, R., \& Schiebinger, L. L. (2008). Agnotology: The making and unmaking of ignorance. Stanford University Press.

Putnam, R. D. (1976). The comparative study of political elites. New Jersey: Prentice-Hall.

Puttonen, V., \& Ståhle, M. (2014). Domestic contrarians win in the long run: A case study. Journal of Asset Management, 15(5), 279-283.

Rahkonen, J. (2006). Journalismi taistelukenttänä: Suomen Natojäsenyydestä käyty julkinen keskustelu 2003-2004 [Journalism as a battlefield: The public debate on a Finnish Nato-membership in 2003-2004] [PhD thesis].

Raisch, S., \& Birkinshaw, J. (2008). Organizational ambidexterity: Antecedents, outcomes, and moderators. Journal of Management, 34(3), 375-409.

Ransdell, E. (2000). The nike story? just tell it! Fast Company, (31: 44-52)

Raunio, T. (1999). Facing the European challenge: Finnish parties adjust to the integration process. West European Politics, 22(1), 138-159.

Rehn, O. (2019). Finland's economic transition still incomplete. Helsinki: Bank of Finland. Retrieved from https://www.bofbulletin .fi/en/2019/5/editorial-finland-s-economic-transition-still -incomplete/

Reinhardt, A. (2003, 23 June). Online extra: Nokia: Suddenly, it's sweating. Bloomberg. http://www.bloomberg.com/news/articles/2003-06-22 /online-extra-nokia-suddenly-its-sweating

Risku, J. (2010). Uusi Nokia: käsikirjoitus [The new Nokia: A manucsript]. Differ Books.

Robinson, J. A. (2010). Elites and institutional persistence. Working Paper No. 2010/85. UNU-Wider. http://www.wider.unu.edu/publications /working-papers/2010/en_GB/wp2010-85/_files/83832092416 409661/default/wp2010-85.pdf

Rolander, N. (2019, 24 October). Nokia tanks after cutting outlook, sacrificing payout for 5G. Retrieved from https://www.bloomberg .com/news/articles/2019-10-24/nokia-cuts-earnings-outlook-and -pauses-dividend-to-invest-in-5g 
Rolander, N. (2020, 2 March). Nokia’s new chairman picks close ally to put it back in 5G game. Bloomberg. https://www.bloomberg.com /news/articles/2020-03-02/nokia-s-new-chairman-picks-close-ally-to -put-it-back-in-5g-game

Romei, V. (2019, 15 December). Europe first: The EU's digital industrialisation challenge. Financial Times. https://www.ft.com/content /73213036-1dd8-11ea-97df-cc63de1d73f4

Roper, C. (2013). Trade secret theft, industrial espionage, and the China threat. Taylor \& Francis.

Roy, D., \& Zeckhauser, R. (2015). Grappling with ignorance: Frameworks from decision theory, lessons from literature. Journal of Benefit-Cost Analysis, 6(1), 33-65.

Ruostetsaari, I. (2007). Nordic elites in comparative perspective. Comparative Sociology, 6(1), 158-189.

Rytilä, T. (2013). What 'Connecting people' really means. Retrieved from https://blogs.windows.com/devices/2013/04/09/what-connecting -people-really-means/

Saari, M. (2000). Kari Kairamo: Kohtalona nokia [The fate of Kari Kairamo: Nokia]. Gummerus.

Sabel, C., \& Saxenian, A. (2008). A fugitive success: Finland's economic future. Sitra.

Sadowski, B. M., Dittrich, K., \& Duysters, G. M. (2003). Collaborative strategies in the event of technological discontinuities: The case of Nokia in the mobile telecommunication industry. Small Business Economics, 21(2), 173-186.

Salo, S. (2007). Taloustutkimus ja Suomen talousstrategia. [Economic research and Finland's economic strategy]. https://www.suomenpankki .fi/sv/medier-och-publkationer/tal-och-intervjuer/2007/pankin johtaja-sinikka-salo-taloustutkimus-ja-suomen-talousstrategia /http://www.bof.fi/en/suomen_pankki/ajankohtaista/puheet/2007 /sspuhe_22082007.htm

Sandelin, M., \& Partanen, J. (2015). Nokian jalokivi: Tarina suomalaisesta DX 200 puhelinkeskuksesta [The Gem of Nokia: A story about the DX 200 digital switching platform]. Mediakasvo Oy.

Sandén, M. (2008, 18 May). Reklamgurun har hittat nya jaktmarker. Retrieved from https://www.di.se/artiklar/2008/5/18/reklamgurun-har -hittat-nya-jaktmarker/

Saxenian, A. (1996). Regional advantage. Harvard University Press.

Schlagwein, D. (2018, 6 December). The history of digital nomadism. Paper presented at the International Workshop on the Changing Nature of Work (CNOW). 
Schneider, M., \& Teske, P. (1992). Toward a theory of the political entrepreneur: Evidence from local government. American Political Science Review, 86(3), 737-747.

Schumpeter, J. A. (1950). Capitalism, socialism and democracy (3d ed.). New York: Harper.

Scott, R., \& Meyer, J. (1994). Institutional environments and organizations. Sage Publications.

Scott, R. W. (2001). Institutions and organizations. Sage Publications.

Seppälä, T. (2010). Transformations of Nokia's Finnish supplier network from 2000 to 2008. In J. Ali-Yrkkö (Ed.), Nokia and Finland in a sea of change (pp. 37-67). Etla.

Seppälä, T. (2013). Tracking offshoring and outsourcing strategies in global supply chains. In T. Pedersen, L. Bals, P. D. Ø. Jensen, \& M. Larsen (Eds.), The offshoring challenge (pp. 57-76). Springer.

Seppänen, E. (2014). Suomen rikkaat: Kuka kukin on [Finland's richest: Who is who]. Minerva.

Shambu Prasad, C., Hall, A., \& Laxmi, T. (2006). Engaging scientists through institutional histories. Institutional Change and Learning Initiative (ILAC). https://www.betterevaluation.org/sites/default/files /ILAC_Brief14_institutional.pdf

Shi, W. (2020, 17 March). Consensus on 6G is gradually forming. Retrieved from https://telecoms.com/503142/consensus-on-6g-is -gradually-forming/

Shiller, R. J. (2002). Irrational exuberance in the media. In R. Islam (Ed.), The right to tell: The role of mass media in economic development (pp. 83-94). The World Bank.

Siilasmaa, R., \& Fredman, C. (2018). Transforming Nokia: The power of paranoid optimism to lead through colossal change. McGraw Hill Education.

Silberman, S. (1999, 1 September). Just Say Nokia. Wired. http://www .wired.com/wired/archive/7.09/nokia.html

Singh, S. K. (2008). The diffusion of mobile phones in India. Telecommunications Policy, 32(9-10), 642-651.

Slywotzky, A., \& Weber, K. (2011). Demand: Creating what people love before they know they want it. Headline.

Sokala, H. (2002). Maailma taskussa: Miten matkapuhelimella tienattiin ja tuhottiin miljardeja [World in the pocket: How billions were earned and lost in mobile phones]. Tammi.

Sölvell, Ö, \& Porter, M. E. (2002). Finland and Nokia: Creating the world's most competitive economy. Harvard Business School case. 
Standage, T. (Ed.). (2005). The future of technology. Profile Books.

Statistics Finland. (2018). Finland among the best in the world. Statistics Finland. https://www.stat.fi/tup/satavuotias-suomi/suomi-maailman -karjessa_en.html

Steinbock, D. (2001). The Nokia revolution: The story of an extraordinary company that transformed an industry. Amacom.

Steinbock, D. (2005). Nokia’s China ambition. Beijing Review, 39. http: //beijingreview.sinoperi.com/en200539/694603.jhtml

Steinbock, D. (2010). Winning across global markets: How Nokia creates strategic advantage in a fast-changing world. Jossey-Bass.

Sucher, S., \& Winterberg, S. (2015a). Nokia's bridge program: Outcome and results (B). Harvard Business Review.

Sucher, S., \& Winterberg, S. (2015b). Nokia's bridge program: Redesigning layoffs (A). Harvard Business Review.

SwedishUnion ofJournalists. (2018).Yrkesregler[Professionalrules].Journalist Förbundet. https://www.sjf.se/yrkesfragor/yrkesetik/spelregler -press-radio-och-tv/yrkesregler

Tallberg, M., Hämmäinen, H., Töyli, J., Kamppari, S., \& Kivi, A. (2007). Impacts of handset bundling on mobile data usage: The case of Finland. Telecommunications Policy, 31(10-11), 648-659.

Tarkka, J. (2007). Erik Dahmén and Finnish economic policy. In N. Karlson (Ed.), Erik Dahmén och det industriella företagandet [Erik Dahmén and the industrial entrepreneurship] (pp. 192-212. Stockholm: Ratio.

Taylor, E. (2020, 16 January). VW CEO says carmaker faces same fate as Nokia without urgent reforms. Reuters. https://www.reuters.com /article/us-volkswagen-strategy-diess-idUSKBN1ZF1OB

Taylor, F. W. (1911). The principles of scientific management. Harper.

Team, T. (2015, 10 December). What Nokia's sale of HERE means. Forbes. https://www.forbes.com/sites/greatspeculations/2015/12/10 /what-nokias-sale-of-here-means/

Tengblad, S. (2006). Aktörer och institutionell teori [Actors and institutional theory]. Gothenburg School of Business, Economics and Law.

The Economist. (2002, 21 November). Computing's new shape: As two industries collide, a new kind of computer may emerge. The Economist. https://www.economist.com/leaders/2002/11/21/computings-new -shape

Thrift, N. (2005). Knowing capitalism. Sage Publications.

Thue, L. (2008). Norway: A resource-based and democratic capitalism. In S. Fellman, M. J. Iversen, H. Sjögren, \& L. Thue (Eds.), Creating 
Nordic capitalism: The business history of a competitive periphery (pp. 394-493). Palgrave McMillan.

Tidd, J., Bessant, J., \& Pavitt, K. (2005). Managing innovation integrating technological, market and organizational change. John Wiley \& Sons.

Tienari, J., Vaara, E., \& Erkama, N. (2007). The gospel according to the market: How journalists frame ownership in the case of Nokia in Finland. In P. Kjær \& T. Slaatta (Eds.), Mediating business: The expansion of business journalism (pp. 187-217). Copenhagen Business School Press.

Tse, E. (2015). China's disruptors: How Alibaba, Xiaomi, Tencent, and other companies are changing the rules of business. Penguin.

Tuchman, G. (1973). Making news by doing work: Routinizing the unexpected. American Journal of Sociology, 79(1), 11-131.

Tuomioja, E. (2020, 28 November). Nokia ja HS [Nokia and HS]. Tuomioja.org. http://www.tuomioja.org/

Tuomioja, E., \& Leppänen, V. (2014). Siinä syntyy vielä rumihia: Poliittiset päiväkirjat 1991-1994 [It will get ugly: A political diary 1991-1994]. Tammi.

Upbin, B. (2007, 26 October). The next billion. Forbes. http://www .forbes.com/forbes/2007/1112/048.html

US Department of Commerce. (2019, 26 November). U.S. department of commerce proposes rule for securing the nation's information and communications technology and services supply chain. https: //www.commerce.gov/news/press-releases/2019/11/us-department -commerce-proposes-rule-securing-nations-information-and

Valkonen, T., \& Vihriälä, V. (2014). The Nordic model - challenged but capable of reform. Copenhagen: Nordic Council.

Van Ham, P. (2001). The rise of the brand state. Foreign Affairs, 80(5).

Van Rooij, A. (2015). Sisyphus in business: Success, failure and the different types of failure. Business History, 57(2), 203-223.

Vecchiato, R. (2017). Disruptive innovation, managerial cognition, and technology competition outcomes. Technological Forecasting and Social Change, 116, 116-128.

Vehviläinen, M. (2002). Teknologinen nationalismi [Technological nationalism]. In T. Gordon, K. Komulainen, \& K. Lempiäinen (Eds.), Suomineitonen hei!: Kansallisuuden sukupuoli [Finnish girl, hey! The gender of nationality] (pp. 211-229). Vastapaino.

Vuokola, J. (2015, 21 June). Enemmän abstraktia ajattelua urien sijaan [More abstarct thinking than careers]. Talouselämä. http://www 
.talouselama.fi/tyoelama/enemman-abstraktia-ajattelua-urien-sijaan $-3477100$

Vuori, T. O., \& Huy, Q. N. (2016). Distributed attention and shared emotions in the innovation process: How Nokia lost the smartphone battle. Administrative Science Quarterly, 61(1), 9-51.

Vuori, T. O., \& Huy, Q. N. (2018, 23 May). How Nokia embraced the emotional side of strategy. Harvard Business Review. https://hbr .org/2018/05/how-nokia-embraced-the-emotional-side-of-strategy

Wang, J., Hedman, J., \& Tuunainen, V. K. (2016). Path creation, path dependence and breaking away from the path: Re-examining the case of Nokia. Journal of Theoretical and Applied Electronic Commerce Research, 11(2), 16-27.

Whitwam, R. (2014, 8 December). Foxconn's robotic workforce isn't precise enough to assemble iPhones. Extreme Tech. http://www .extremetech.com/electronics/195556-foxconns-robotic-workforce -isnt-precise-enough-to-assemble-iphones

Wiarda, H. J. (1997). Corporatism and comparative politics: The other great "ism". Armonk, NY: M.E. Sharpe.

Wintrobe, R. (2000). Political economy of dictatorship. Cambridge University Press.

Xing, Y. (2014). China's high-tech exports: Myth and reality. National Graduate Institute for Policy Studies. https://www.grips.ac.jp/r-center /wp-content/uploads/11-05.pdf

YLE. (2003, 13 August). Sonera eavesdropping probe expands. Retrieved from http://yle.fi/uutiset/sonera_eavesdropping_probe _expands/5147244

Young, J. S. (1999, 25 March). Wireless wonderland. Forbes. http://www .forbes.com/1999/03/25/feat.html 



\section{Index}

\section{Symbols}

5G technology 3, 49, 152, 198, 209 6G technology 210

\section{A}

Aalto-Setälä, Pauli 69

Aalto University 31,40

Aamulehti 105

Accenture 183, 201

Aho, Esko 38, 39, 50, 99

Ahonen, Tomi H. 16, 208

Ahtisaari, Martti 98

Ahto, Yrjänä 117

Ala-Fossi, Marko 33

Alahuhta, Matti $\quad 80,84,85,86$, $87,89,127$

Ala-Mursula, Juha $\quad 163,165,200$
Ala-Pietilä, Pekka $\quad 80,84,86$, 89, 125

Alcatel 48

Alcatel-Lucent 189, 214

Alexander Corporate

Finance 105

Alho, Arja 98, 107

Alitalo, Pirkko 85

Ali-Yrkkö, Jyrki $\quad 10,104,123,150$

All Things Digital 203

ambidexterity 174

Amer 105

Andersson, Robert 126, 138, 167

Android operating system 4, 6, $90,150,156,167,169,178$, $182,195,203,206,212$

Anglo-Saxon management model 2, 60, 68, 85, 105 
Anholt, Simon 12

Ankcorn, John $\quad 82,169,180$,

196, 200, 201

Apple 4, 10, 15, 90, 93, 101, 116, 139, 150, 151, 158, 167, 171,

$173,174,178,181,185$, 193,213

ARM 132

Aromäki, Juhani 59

Asea Brown Boveri 98

Asperation 128

Aspocomp 128, 154

asymmetric information 88,172

AT\&T $\quad 100,173,191,193$

auctions, network 33, 34

Audi 213

Augusto, Lopez Claros 45

Auvinen, Ollijuhani 143

B

Baldauf, Sari $\quad 80,84,85,86,89$, $144,211,217,218$

Ballmer, Steve $199,202,205$, 207, 208

Bank of Finland $\quad 13,57,58,108$

Baril, Jean-François 92, 126, $127,128,151,168$

Barnett, William P. 174

Bathina, Sridhar 153

Bennett, Drake 171

BenQ 139

Beresford-Wylie, Simon 162

Bergqvist, J.-T. 187

Billionaires' Club 57

Blackberry

see RIM.

Blandaren 116

Blom, Anders 49

Blom, Jan 158

Bloomberg 211, 218
Blåfield, Antti 85

BMW 213

Boethius, Jan 61

Boken om Nokia (Bruun \& Wallén) 8

Bonet, Montse 33

Borenius \& Co 54

Brandenburger, A. M. 121, 136

branding and marketing 111

Connecting People slogan 115,190

history used as 9

nation branding $6,11,111$

product placement 115

sports sponsorship 100,114

broadband strategy 33

Broadcom Corp 163

Bruun, Staffan 8

Business the Nokia Way

(Merriden) 8

Businessweek 203

Business Week 67, 69,70

BYD 132, 138, 146, 149, 151

C

Capital Markets Day 171

caravan capitalism 92

Carlsson, Bengt 1

car-navigation systems 213

CDMA standard 146, 191

Center for Responsive

Politics 100

Centre Party 37, 50, 96, 99

CEPT (European Conference

of Postal and

Telecommunications

Administrations) 47

CES trade fair, Las Vegas 192

Challenger Mindset project 202

charismatic management 87 
Chicago School 62

Chin, Sam 151

China $3,126,130,138,143$, 198

Chipchase, Jan 158

Christensen, Clayton 171, 175, 217

Cigar Angels motorcycle club 136

Citibank 58, 59

Citigroup 85

Cityman phone 115

clamshell phones 89,190

Club Nokia 89,183

cluster strategy $127,128,137$

CNet 171

C-Netz 47

Cobham, Alex 101

Collins, Jim 87

Collins, Paul 85, 89

Communities Dominate Brands

(Ahonen) 16

Compaq 51, 126

Confederation of Finnish

Industries 53, 218

confirmation bias 76

Connecting People slogan 115,190

contract manufacturing, 58 , 104, 107

China $126,130,138,143$

cluster strategy $127,128,137$

crisis for Finnish

companies 121, 135

Elcoteq 128, 135, 155

India 154

Cook, Tim 201

Co-opetition (Brandenburger \&

Nalebuff) 121, 136

Cord, David J. 16

corporate governance 84

corporation tax 103 corruption 95, 101, 149

Council for Mass Media 72, 73

Covid-19 158, 209

creative destruction 131

Cronberg, Tarja 51

cultural circuit of capital 61

D

Dagens Industri 73

Dagens Nyheter 30,73

Dahmén, Erik 56

Daimler-Benz 213, 215

Danske Bank 140

Dark Knight, The (film) 115

Decline and Fall of Nokia, The (Cord) 16

Deloitte 198

Demos (think tank) 12

Denmark 46, 47

Deutsche Telekom 47, 48

DeVard, Jerri 117

Diess, Herbert 212

Digital Equipment Corporation 87

Digital Europe 40

dividends 63, 64, 103

Dougal, Casey 75

Doz, Yves 15, 17, 88, 137

dual-SIM phones 159

DX 200 digital switching platform 44, 57

Dyck, Alexander 75

E

E71 phone 171

economic recession 13

see also global financial crisis.

Economist, The 179

economy

see Finnish economy.

education system $\quad 31,56$ 
Ehrnrooth, Casimir $\quad 84,97$

Ehrnrooth, Georg 85, 105

Eimo 128, 129

Elcoteq 128, 135, 155

election campaign funding

96,101

Elektrobit 165

Elite Alfred Berg 106

Elliot, Kent 187

Elop, Steven $16,17,71,88,100$,

$117,151,183,199,200$,

201, 204, 205, 206, 213

Eloranta, Eero 125

employee wages 64

Enron 10

Enterprise Resource Planning (ERP) 90

EQT 129,130

Ericsson $10,34,35,44,46,48,54$, $101,116,140,146,148,171$, $177,179,182,186,210,215$

Eriksson, Lars Magnus 111

Erkama, Niina 76

Espoo, Finland 104, 151, 161

Etla Economic Research

Instutute 2, 10, 104, 123,

128,150

Etzkowitz, Henry 38

European Conference of Postal

and Telecommunications

Administrations (CEPT) 47

European Telecommunications

Standards Institute

(ETSI) 47

European Union 34, 48, 50, 215

exports $3,106,122,150$

F

Facebook 119, 159, 181, 184

fact-based management $\quad 81,168$
Family Business Network Finland 83

Fang Min 209

Federal Election Commission,

US 100

Fellman, Peter 73

Ferrari 114

fibre networks 33

FIH Mobile 152

financial aid 41

Financial Times 14, 69, 89,111

Finland and Nokia (Sölvell \& Porter) 9, 13

Finland Promotion Board 11

Finnair 50, 187

Finnish Broadcasting Company

(YLE) 107

Finnish Companies Act 99

Finnish Competition

Authority 18

Finnish court system $\quad 52,54$

Finnish economy 2, 13, 56,

57,216

Finnish Financial Supervisory

Authority 104

Finnish Forest Industries

Federation 59

Finnish Funding Agency for

Technology and Innovation

(Tekes) 14, 42, 51, 56,

164, 205

Finnish government 29, 200

accession to European

Union 50

broadband strategy 33

education system 31,56

financial aid 41

Kairamo and 36

Lex Nokia 52, 117

network licences 33,34 
Nokia's influence over legislation 52, 117

Ollila and 35, 36 parliamentary committees 50 tax policy 41 technical standards 45 use of Nokia phones 50

Finnish Innovation Fund (Sitra) 14, 15, 56, 60, 108 Finnish National Bureau of Investigation 52

Finnish Tourist Board 11

Five, The (executive team) 80 , 85,90

flip phones 89,190

Forbes $68,70,111,171$

Foreign Policy 101

foreign trips for journalists 72

forestry 59

Formula One sponsorship 114

Fortum 50, 218, 219

Foulger, Josh 153

Foxconn Technology

Group 127, 129, 132, 136, $137,138,139,145,149$, $150,151,152,157$

France 47

France Telecom 47, 48

Fredman, Catherine 17, 91, 203

Friedman, Milton 62

F-secure 183

Fugitive Success

Finland's Economic Future

(Sabel \& Saxenian) 14

G

Gad, Thomas 118

game theory 121

Gazprom 3

General Electric $\quad 46,62$
General Motors 30

Germany 47, 92, 170

Ginko Ventures 151

global financial crisis 140, 170,171

global village metaphor 157

Goggin, Gerard 7, 111

Google 4, 15, 90, 101, 158, 167, 181, 195, 202

Gorbachev, Mikhail 115

Gou, Terry 128, 145, 151

GPRS (General Packet Radio Service) $\quad 170$

Grameen Bank 154

Green League 98

Green, Rich 195

group think 76

GSM standard $34,43,46,47$, 146, 191

Guardian, The 184

H

Haavisto, Heikki 98

Hackman 218

Halonen, Tarja 98

Hansaprint 131

Hansen, M. T. 174

Harvard Business Review 149

Harvard Business School 10

HCL Technologies 42, 153

headquarters building 162

Healthradar application 158

Heino, Timo-Erkki 107

Helaniemi, Erkki 105

Helin, Pekka 162

Hellström, Kurt 49, 90

Helsingin Sanomat $14,42,53$, $59,68,70,76,85,104,118$

Helsinki University of

Technology $31,32,162$ 
HERE location mapping data service 213

Herlin family 83

Hewlett-Packard 126

Hill, Andrew 89

HMD Global 126, 151, 216

Holmström, Bengt 85

Hon Hai Precision Industry

Co 152

see also Foxconn Technology

Group.

Honkavaara, Topi 143

HSDPA (High Speed Downlink

Packet Access) 191

HTC 139, 171, 204

Huawei $\quad 35,52,146,148,210,215$

Huczkowski, Ari 162

Hufvudstadsbladet 200

Huy, N. Quy 82

Häggman, Kaj 197

Häikiö, Martti $\quad 9,36,84,125$

Häkämies, Jyri 42

Hänninen, Jyri 104

\section{I}

Iannucci, Bob 195

Ibison, David 14

IBM 10

Iceland 13,47

Ihalainen, Lauri 42

Ihamuotila, Timo 89

Ilmonen, Urho 53

Iltalehti 69

Imbera Electronics 128

Inderes 218

India $4,153,186$

Information Society Code 54

Innovator's Dilemma, The

(Christensen) 175, 217 institutional theory 5,8

Instrumentarium 105

intellectual property rights 52 ,

$117,124,148$

interest rates 58

iOS operating system $\quad 90,150$, $178,182,195$

iPhone 4, 6, 51, 93, 139, 150, $170,171,173,174,185$, 193, 213

Italy 47

Iversen, Martin Jes 45

J

Jabil 137

Jauhiainen, Jussi S. 28

Jennings, Jason 174

Jobs, Steve $173,174,185,193$,

194

journalistic ethics 72

Junkkari, Markku 76

K

Kairamo, Kari $31,36,56,57,58$, $68,96,97,113,143$

Kaivo-Oja, Jari 53

Kaleva 53, 163

Kallasvuo, Olli-Pekka 16, 70, 71, $80,86,89,100,162,168$, 170, 172, 173, 187, 192, 201

Kansallis-Osake-Pankki

Bank 58, 83, 85, 105

Karlsson, Svenolof 186

Kathuria, Rajat 156

Kauppalehti 72, 73

Kaurismäki, Aki 112

Ketonen, Timo 131

Kilmer, Val 115 
Kivinen, Lauri $\quad$ 1, 99, 112, 117, 118 Lingyi iTech 130

Kiviniemi, Mari 200

Linkedin 159

Kodak 175

Linux operating systems $\quad 169,182$

Koivisto, Mauno 97

Kokkonen, Marketta 162

Lipponen, Paavo 39, 41, 98, 107

Lite-On 129

Kone Corporation 87, 107, 116

Littmann, D. 198

Konecranes 116, 218, 219

Kopra, Yrjö 105

Korhonen, Jarmo 97

lobbying and politics 95

lock-in 45

Korhonen, Pertti 89, 125, 126

Lohja Corporation 105, 135

Koskinen, Lauri 44

London Stock Exchange 58

Kosonen, Mikko $\quad$ 15, 93, 109, 182

Lugn, Anders 186

Kotka, Jan 139

Lumia phones 51, 157, 196, 212

Lundmark, Pekka 187, 217

Kotter, John P. 206

Kuisma, Markku 105, 208

Kulvik, Hannes 61

Kuusi, Juhani 43

M

Maemo/MeeGo operating system $169,174,178$, 199, 203

L

labour market agreement 13

Lassila, Anni 62

Laukamo 131

Lazonick, William 64

Lee, Kai-Fu 149

Lee, Kwan Min 206, 212

legislation, Nokia's influence over 52,117

Leinonen, Hannu 73

Leningrad Cowboys (rock group) 112

Leskinen, Jouko K. 85

Lex Nokia 52, 117

Leyen, Ursula von der 215

LG 171, 191, 204, 214

licences, network 33, 34

Lifeblog service 183

Lindén, Suvi 54

Lindholm, Christian $\quad$ 179, 184, 185

Lindström, Kim 108

\section{3}

Maestri, Luca 158

Mannerheim, Carl Gustaf Emil 11

market segmentation strategy 173

market-based standards 48 marketing see branding and marketing. Massachusetts Institute of Technology (MIT) 85

Matilainen, Pekka 69 matrix organisational model 88 Matrix, The (film) 115 Matsushita 177 Mattila, Markku 65 Mazzucato, Mariana 43 McDonald's 116 McDowell, Mary 89 McGovern, Frank 125 McKinsey $125,172,181$ McLuhan, Marshall 157 
McNealy, Scott 201

media relations 67

MediaTek 165

MeeGo/Maemo operating system 169, 174, 178, 199, 203

Meltemi operating system $\quad 169$, $178,199,200$

Merkel, Angela 92

Merriden, Trevor 8

Metra 85

Michelsen, Karl-Erik 31

Microcell 52

Microsoft $4,10,16,93,99,101$, $139,150,151,152,156$, $157,163,164,178,181$, 196, 199, 213

Miettinen, Anssi 104

Mildh, Harry $95,98,99$

mobile phones

clamshell phones 89,190

creating brand with 114

dual-SIM 159

E71 phone 171

focus on 59

HMD Global 126, 151, 216

India $4,153,186$

iPhone 4, 6, 51, 93, 139, 150, $170,171,173,174,185$, 193,213

Lumia phones 51, 157, 196, 212 management failures in $2008 \quad 167$ market segmentation strategy 173

market share $51,171,190$

N97 phone $170,185,195$

Nokia Communicator 50, 115,186

phone credit payments 158

product placement 115

ring tone 115

sale of business to Microsoft
$16,89,99,157,163,164$, 199,213

sales of 123,212

touch screens 185

United States 189

use by Finnish government 50

WiFi 186

see also contract manufacturing; operating systems; technical standards.

Moblin 169

Motorola 46, 54, 116, 129,

$148,171,177,179,182$,

189,190

MTV3 143

Murto, Risto 204

Myllylä, Yrjö 53

Mäkinen, Marco 8

N

N97 phone $170,185,195$

Nadella, Satya $\quad 205,207$

Nalebuff, B. J. $\quad$ 121, 136

nanotechnology 44

nation branding $6,11,111$

National Bureau of

Investigation 101

National Coalition Party 35, 42, 50, 54, 85, 97

National Union of University

Students 37

Navteq 63

Netherlands 3, 47

network licences 33, 34

Neuvo, Yrjö 50, 188, 195

New York Stock Exchange 59, 74, 190

New York Times 62

Newsweek 11, 111

4, Niinistö, Sauli 41 
Nike 9, 116

Nilsson, Christer 217

Nobel, Alfred 111

Nokia Communicator 50, 115,186

Nokia Internet

Communications 186

Nokia Money 158

Nokia nomads 157

Nokia Revolution, The (Steinbock)

Nokia Saga 8

Nokia Siemens Networks

(NSN) 214

'Nokia Tune' 115

Nordea 85, 165

Nordell, Fjalar 44

Nordic Mobile Telephony (NMT) standard 34, 43, 45

Nordic Semiconductor 165

North, Douglass 5

Norway 47

Nykänen, Matti 114

Nykänen, Pekka 16, 72, 203

Nyström, Sebastian 181

O

Obopay 158

Oilinki, Juuso 101

Ojanperä, Tero 93

Ollila, Jorma $\quad 8,9,11,17,58,155$, $162,169,172,180,200,201$

at Citibank 58, 59, 60

China and 144

education system and 31,32

Finnish economy and 59,62

Finnish government and 35, 36

focus on mobile phones 59

income and share options 104, 107

lobbying and politics $\quad 97,98$ management style and personality 79

media relations $67,71,75,76$

memoirs $37,40,41,60,68$, $79,85,87,89,91,117,125$, $126,170,180,194$

profit warning 125 share buybacks and 64 trade unions and 65

WiFi strategy 186

Operaatio Elop (Nykänen \& Salminen) 16

operating systems $\quad 90,150$

Android 4, 6, 90, 150, 156, $167,169,178,182,195$, 203, 206, 212

iOS $90,150,178,182,195$

Linux 169, 182

Maemo/MeeGo 169, 174, 178, 199, 203

Meltemi 169, 178, 199, 200

Symbian $16,17,89,90,150$, $168,169,174,177,185$, 195, 199

Tizen OS 206

Windows Phone $16,156,178$, 183, 196, 199, 202, 204, 206, 213

Organizational Health Index (OHI) 172

Ormala, Erkki $\quad 40,170,174,188$

Oulu University of Applied

Sciences 164

Oulu, Finland $\quad$ 104, 163, 208, 213

\section{$\mathbf{P}$}

Paananen, Jalo 127, 129

Paananen, Reijo 187, 217

Page, Scott E. 45

Palm Pilot 185 


\begin{tabular}{|c|c|}
\hline almu, Anne-Liisa & $\mathbf{R}$ \\
\hline parliamentary committees 50 & Radiocom $2000 \quad 47$ \\
\hline patent agencies 54 & RadioShack 190 \\
\hline patents 215 & Ramp Networks 153 \\
\hline Pauly, François 139 & Rantanen, Paavo 98,117 \\
\hline pay & Raunio, Tapio 49 \\
\hline employee wages 64 & Rautanen, Mikael 218 \\
\hline gap between executives and & Realini, Carol 158 \\
\hline workers 107 & Red Queen effect 175 \\
\hline see also share options. & Reeves, Keanu 115 \\
\hline PC World 171 & Reinhardt, Andy 69 \\
\hline Peltonen, Petri 200 & Reinventors (Jennings) 174 \\
\hline Perlos $124,128,129,130,154$ & reorganisation of 200486 \\
\hline $\begin{array}{l}\text { Personal Digital Assistants } \\
\text { (PDAs) } 185\end{array}$ & $\begin{array}{l}\text { Research and Innovation } \\
\text { Council }\end{array}$ \\
\hline $\begin{array}{c}\text { Petersen, Søren Jenry } 132 \text {, } \\
180,196\end{array}$ & $\begin{array}{l}\text { see Science and Technology } \\
\text { Policy Council. }\end{array}$ \\
\hline $\begin{array}{l}\text { Philips } 165 \\
\text { phone credit payments } 158\end{array}$ & $\begin{array}{l}\text { RIM } 138,140,165,171 \\
\text { ring tone } 115\end{array}$ \\
\hline Piippo, Antti $135,138,141$ & Ringtone (Doz \& Wilson) 17 \\
\hline Pohjola 85 & Risku, Juhani 16 \\
\hline olitics and lobbying 95 & Rodamvom 85 \\
\hline Porter, Michael E. 9, 13 & Ross, Wilbur 148 \\
\hline PricewaterhouseCoopers 60 & Rothstein, Bo 101 \\
\hline product placement 115 & Royal Bank of Scotland 140 \\
\hline profit warning 125 & Royal Dutch Shell 3, 38 \\
\hline Protopaja 131 & RTMI/RTMS 47 \\
\hline Psion 177 & Russia 3,38 \\
\hline public image 67 & Rytilä, Tuula 116 \\
\hline Purasjoki, Matti 18 & Röning, Juha 163 \\
\hline Pursiainen, Harri 34 & \\
\hline Puttonen, Vesa 103 & \\
\hline Pärnänen, Pekka $192,195,196$ & $\mathbf{S}$ \\
\hline & en, Esa 87 \\
\hline Q & $\begin{array}{c}\text { Saarinen, Matti } \quad 37,98,112, \\
114,118\end{array}$ \\
\hline $\begin{array}{l}\text { Qualcomm 132, 146, 170, } 191 \\
\text { Quality of Government }\end{array}$ & $\begin{array}{c}\text { Saarnivaara, Veli-Pekka } 43, \\
130,180\end{array}$ \\
\hline Institute, Gothenburg & Sabel, Charles $14,60,125$ \\
\hline University 101 & Saint, The (film) 115 \\
\hline
\end{tabular}


Salcomp 130

Salminen, Merina 16, 203

Salminen, Sakari 213

Salo, Finland 104, 164, 213

Samad, Abdul 156

Sampo 85

Samsung 3, 51, 88, 139, 150, 156, 171, 177, 189, 191, 204, 206, 212, 214

Sandelin, Martin 59, 74, 117, $182,190,191$

SAP software 90

Sarlin, Tommi 69

Sasi, Kimmo 34, 36, 50

Satama Interactive 184

Saukkomaa, Harri $37,40,41$, $60,68,79,85,87,89,90$, $125,170,180,194$

Savander, Niklas $\quad$ 168, 201

Savcor 148, 154

Savisalo, Hannu 148

Saxenian, AnnaLee 14,60 , 125, 197

Scardino, Marjorie 70

Schumpeter, Joseph $\quad 55,131$

SCI 135

Science and Technology Policy

Council 38, 40

scientific management 81

SEB 140

Seligson, Peter $\quad 106,108$

Seppälä, Timo $\quad 128,138,139$

Seppänen, Esko 104

Seppänen, Pekka 105

Seppo Laine Oy 54

share buybacks 63

share options $75,90,103,117$

share price $8,63,74,106,108$, 117,211

shareholder value $\quad 62,63$ shareholders 83

dividends $63,64,103$

journalists as 74

see also share options.

Sharp 139

Shivakumar, D. 153

Sibelius, Jean 11

Siemens $48,139,154,170,177$, 214,215

Siilasmaa, Risto $17,82,91$, $171,183,194,202,203$, $205,208,211,214$, 216, 218

Siimes, Suvi-Anne 32, 41

Siitonen, Tuomo 162

Silicon Valley 4, 6, 158, 197

Simonsen Radio 46

Sipilä, Juha 106

Sitra (Finnish Innovation

Fund) $14,15,56,60,108$

Sjöman, Henry $\quad 135,140,141$

ski jumping sponsorship 114

Skype 193, 207

Smith, Bradley 100

Social Democratic Party 39, 41, $42,57,96,97$

Sohlberg family 129

Sokala, Hannu 68

Solidium 29

Sonera 108

Sony 171,214

Soros, George 58

South Korea 3

Soviet Union $11,12,112$

spokesperson model of media relations 68

Sponsor Oy Ltd 61

sports sponsorship 100,114

Spängs, Thorbjörn 30,73

stakeholder relationship theory 7 
Standage, Tom 137

Statistics Finland 12

Steinbock, Dan 8, 9, 48, 143

Steinbrück, Peer 92

STM Electronics 132

Stora Enso 50

Store Nordiske Telegraf Selskab 46

Storno Radio Copenhagen 46

Strandberg, Ove 118

strongbox contract 96

Sträng, Gunnar 31

Stubb, Alexander 189

Ståhle, Michael 103

subcontractors

see contract manufacturing.

Sucher, Sandra 92

Sugar Bowl sponsorship $\quad$ 100, 114

Sundbäck, Veli 92

Sundqvist, Ulf 56, 57

Suomen Kuvalehti 12

Suri, Rajeev $102,117,210$,

$$
211,216
$$

Sweden 31, 47, 73

Swedish Employers Association (SAF) 113

Swedish People's Party of

Finland 96

Swedish Union of Journalists 73

Symbian operating system 16, $17,89,90,150,168,169$, 174, 177, 185, 195, 199

Söderling, Petra 172, 182

Sölvell, Örjan 9,13

$\mathbf{T}$

TACS 47

Tallberg, Andreas 124, 129, 130,131
Talouselämä 87

Tandy 190

Tárregan, Francisco 115

Tata Consulting Services 42

taxation 104

Finnish tax policy 41

Indian tax policy 154

personal tax data reporting 69

Taylor, Frederick Winslow 81

Taylorism 81

Technical Research Centre of Finland Ltd (VTT) 15, $56,162,164$

technical standards 45

CDMA 146,191

GSM 34, 43, 46, 47, 146, 191

market-based 48

NMT 34, 43, 45

Tekes (Finnish Funding Agency for Technology and Innovation) $14,42,51$, $56,164,205$

telecommunications

deregulation 32

Telenokia 57, 108, 213

Telenor 44,47

Televa 44,57

Telia 44

Tengblad, Stefan 6

Texas Instruments $\quad 132,190$

Thrift, Nigel 61

Thue, Lars $\quad 45,47$

Tidd, Joe 93

Tienari, Janne 76

Tilli, Kari 205

Tizen OS 206

touch screens 185

trade unions 65,96 
Transforming Nokia (Siilasmaa \& Fredman) 17

Transparency International 101

Trump, Donald 148

Tse, Edward 144

Tuomioja, Erkki 71, 98

Tyrrell Racing Organisation 114

$\mathrm{U}$

Uddenfeldt, Jan 186

Union Bank of Finland

United Kingdom 47

United States 6, 59, 74, 99, 100, $186,189,210$

University of Oulu $\quad 31,163$

Uosukainen, Riitta 50

UPM 50

V

Vaara, Eero 76

Vainio, Vesa 85

value-added 3

van Oordt, Robert 85

Vanhanen, Jorma $\quad 135,141$

Vanhanen, Matti 30, 32, 37, 39, $53,83,113,155$

Vanjoki, Anssi 18, 88, 89, 90, 93, 112, 115, 151, 162, 168,173

Vapaavuori, Jan 42

Vasara, Antti 15

Vehviläinen, M. 28

Vehviläinen, Mika 187

vertical business model, $58 \quad 137$

Vienna Systems 187

Viinanen, Iiro 85

Village Phone project 154
Virtanen, Erkki $\quad 35,36,42,130$

Viswanathan, Harish 209

Vodaphone 184

VOIP (Voice over Internet Protocol) 186

Volkswagen 137, 212, 215

Volvo 31

Vox blogging service 192

VTT (Technical Research

Centre of Finland Ltd)

$15,56,162,164$

Vuokola, Jonna 87

Vuori, Timo 82

Vuorilehto, Simo 30, 105

Väinölä, Petri 146

Väyrynen, Paavo 98

W

wages and employment 64

Wall Street Journal 203, 205

Wallén, Mosse 8

Wallenberg family $\quad 83,105$

Waris, Klaus 56

Welch, Jack 62

Westerback, Patrik 106

Westlund, Jorma 39

Widomski, Stefan 115

WiFi 186

Wilson, Charles 30

Wilson, Keeley 137

WiMAX 187

Windows Phone operating system $16,156,178$, 183, 196, 199, 202, 204, 206, 213

Winning Across Global Markets (Steinbock) 9

Winter War 11 
Winterberg, Susan 92

Wired 111, 171

Woolcock, Michael 93

work efficiency 81

World Economic Forum 45

Wärtsilä 50

Y

Yahoo 193

YLE (Finnish Broadcasting

Company) 50, 51, 71, 73, 107, 208

Yliopisto-Lehti 69
Yli-Saunamäki, Tapani $\quad 39,95$, $98,99,113,114$

Yunus, Mohammad 154

\section{Z}

Zilliacus, Thomas 208

Zingales, Luigi 75

ZTE 146, 209

Zuckerberg, Mark 119

Ö

Öistämö, Kai $\quad$ 168, 201, 203 
ingdom of Nokia tells a fascinating story of corporatism in Finland. How did the mobile phone giant Nokia make the Finnish elite willing to serve the interests of the company?

Nokia became a global player in mobile communications in the 1990s, and helped establish Anglo-Saxon capitalism in Finland. Through its success and strong lobbying, the company managed to capture the attention of Finnish politicians, civil servants, and journalists nationwide. With concrete detailed examples, Kingdom of Nokia illustrates how Nokia organised lavishing trips to journalists and paid direct campaign funding to politicians to establish its role at the core of Finnish decision-making. As a result, the company influenced important political decisions such as joining the European Union and adopting the euro, and further, Nokia even drafted its own law to serve its special interests. All this in a country considered one of the least corrupt in the world.

Carl-Gustav Lindén is an Associate Professor of Data Journalism at the University of Bergen and Associate Professor (Docent) at the University of Helsinki. Lindén's background is in journalism, and he was a business journalist working for newspapers, magazines, and television until 2012, when he turned to academia.

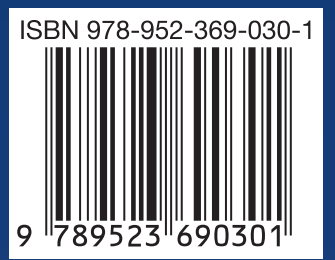

